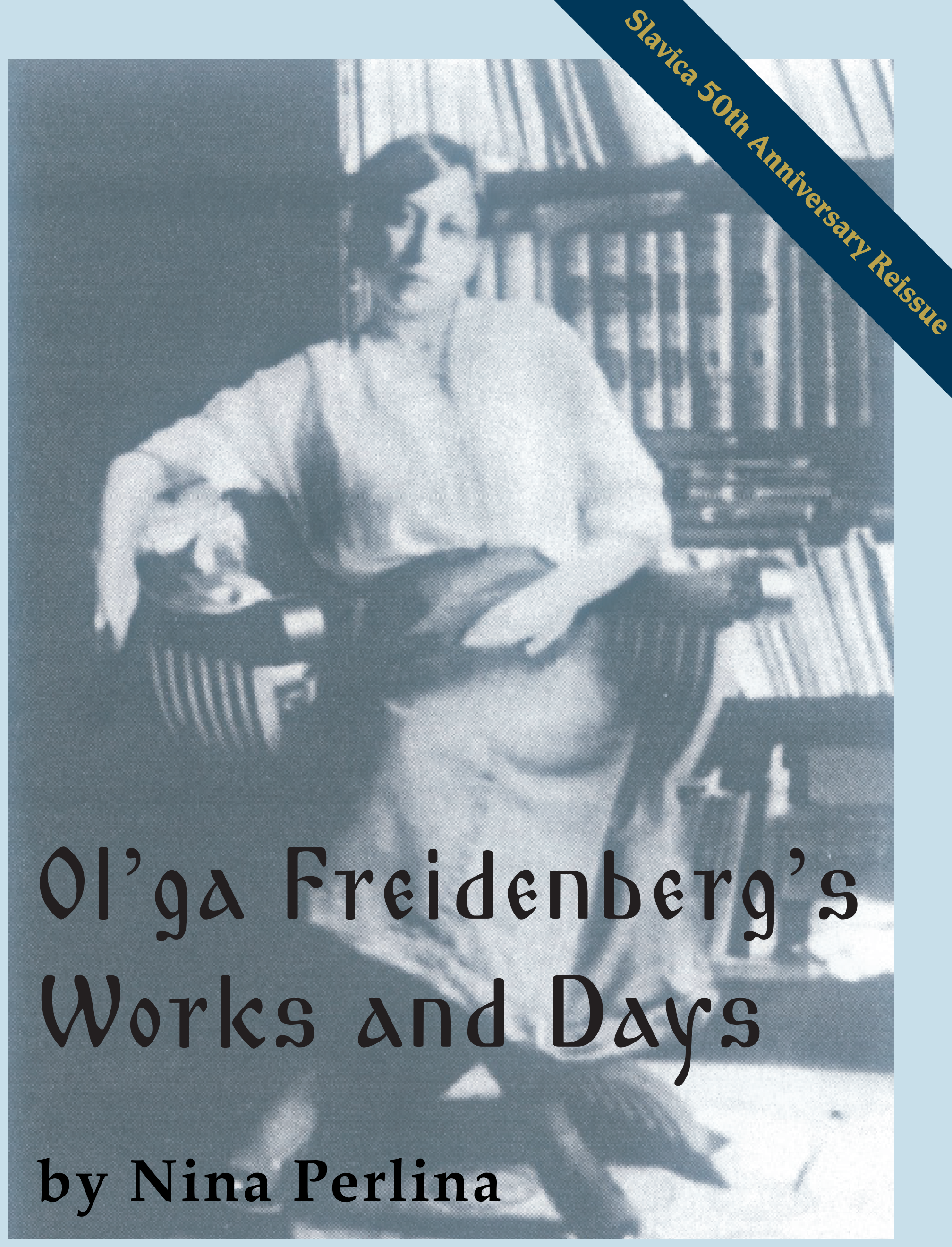




\section{From the Publisher}

This book represents the sixth in a series of reprints of notable titles published by Slavica and long out of print. We are restoring these titles to print and making them available as free downloads from our web site, slavica.indiana.edu, in honor of Slavica's fiftieth anniversary. Yes, we are officially middle-aged. Founded by four graduate students at Harvard in 1966, Slavica published its first book in 1968, Studies Presented to Professor Roman Jakobson by His Students. To celebrate Slavica's jubilee, we are releasing in .pdf format, no strings attached, scans of twelve older titles that have been requested over the years. Enjoy these books, tell your friends, and feel free to share them with colleagues and students.

Unlike the other titles we are releasing as part of this jubilee series, Ol'ga Friedenberg's Works and Days is not out of print, so if you want to own the printed book, don't hesitate to order it. However, the book has never been distributed widely in Russia, where its primary readership is actually located, so this seemed like an auspicious opportunity to make it available to scholars in Russia. Nina Perlina was our colleague at Indiana University when she published this book with Slavica, the first from our local faculty to take advantage of the fact that we now run a publishing house.

Slavica would like to express its sincere thanks to Nina Perlina for graciously granting permission for this reprint. We welcome comments on this and other forthcoming titles to be released in this series.

George Fowler

Director, Slavica Publishers

Bloomington, Indiana

13 June 2016 


$$
-
$$




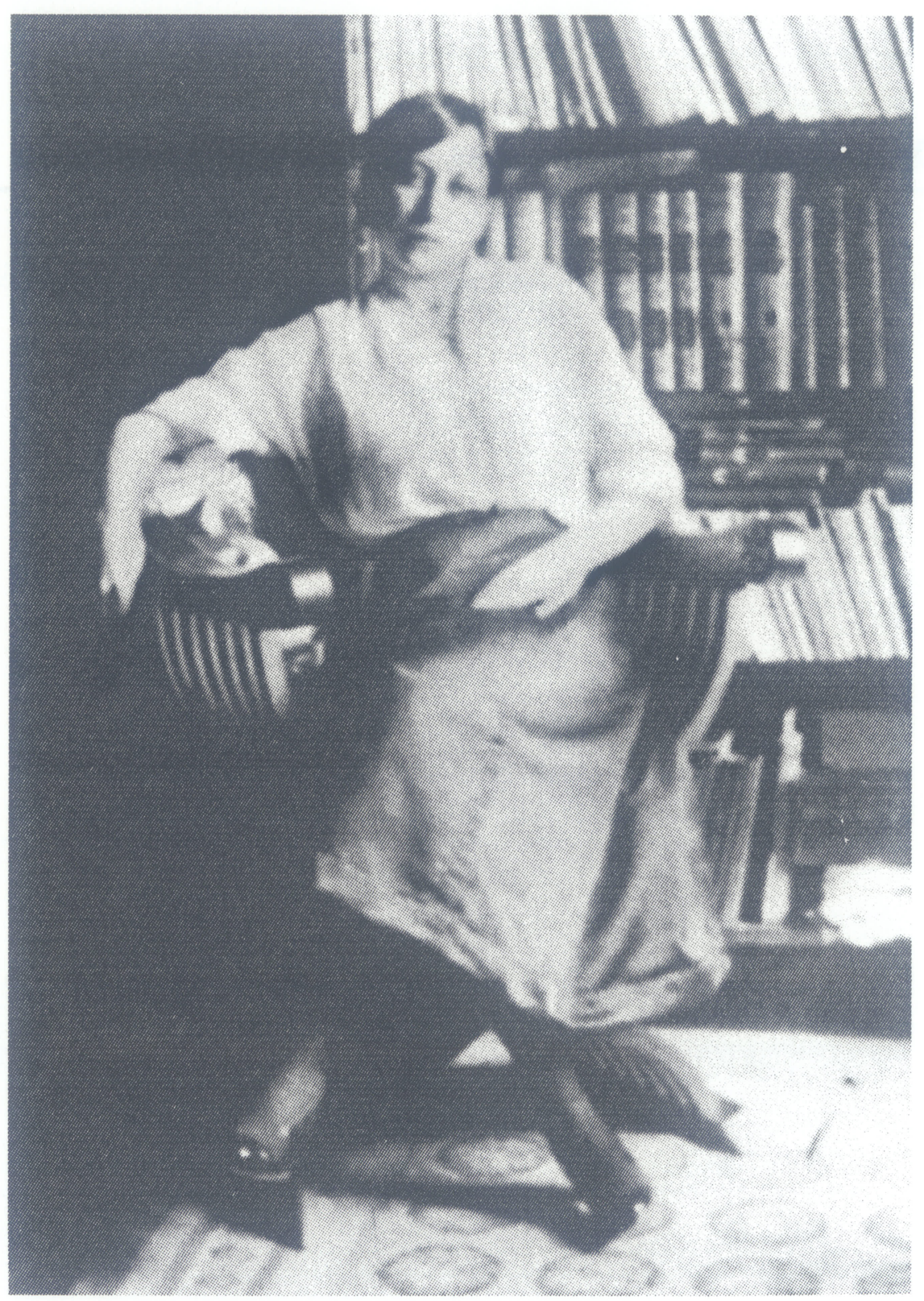

$$
\text { oppenpentegn }
$$




\section{OL'GA FREIDENBERG'S WORKS AND DAYS}

Nina Perlina

Bloomington, Indiana, 2002 
Copyright $\odot 2002$ by Nina Perlina. All rights reserved.

Technical Editor: Vicki Polansky

Cover: from a drawing for the engraving "Ekaterinskii kanal," 1920, by A.P. Ostroumova-Lebedeva

Library of Congress Cataloging-in-Publication Data

Perlina, Nina, 1939-

Ol'ga Freidenberg's works and days / Nina Perlina.

p. $\mathrm{cm}$.

Includes bibliographical references and index.

ISBN: $0-89357-304-3$

1. Freædenberg, O. M. (Ol§'ga Mikhaælovna), 1890-1955.

2. Critics--Soviet Union--Biography. 3. Literature and folklore. 4. Structuralism (Literary analysis) I. Title.

PN75.F67 P47 2002

809--dc21

[B]

2002030520

Slavica Publishers

[Tel.] 1-812-856-4186 Indiana University 2611 E. 10th St.

Bloomington, IN 47408-2603 USA [Toll-free] 1-877-SLAVICA [Fax] 1-812-856-4187 [Email] slavica@indiana.edu [www] http://www.slavica.com/ 
List of Illustrations …....................................................................... iv

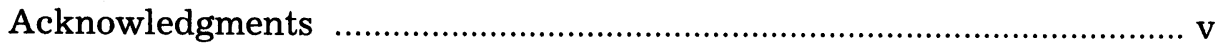

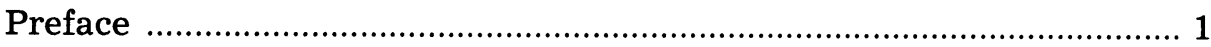

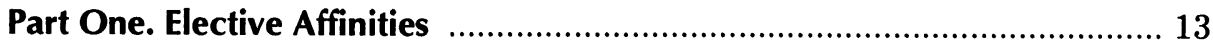

1. Ol'ga Freidenberg and Boris Pasternak on Their Personal Experience and on Cultural Values of Their Time ......................... 17

A. Recollections of Childhood and Youth: Composition of the Narrative

B. Freidenberg and Pasternak Reflect on a Common Historical and Philosophical Background

Part Two. The Years of Apprenticeship 43

2. At the Department of Classical Studies: A Female University Student of a New Type

A. One of the First Women Enrolled at Petersburg University .... 45

B. Studying "The Acts of Paul and Thecla" under Zhebelev's Direction

C. Tracing Similarities between the Early Christian Apocrypha and the Ancient Greek Erotic Novel 53

D. Freidenberg's Conflict with Her University Teachers 58

3. Studying under the Aegis of Nikolai Marr 69

A. A Foster Child or a Stepdaughter in the Marrist Family? ....... 69

B. Excursus into the Japhetic Theory by Nikolai Marr 71

C. Meeting I. G. Frank-Kamenetskii, Life-Long Friend and Like-Minded Thinker

D. Frank-Kamenetskii and Freidenberg Assimilating Cassirer's Philosophical Principles 
Part Three. Becoming a Mature Scholar 97

4. Ol'ga Freidenberg: A Cassirer Scholar in Marrist Garb 99

A. To Yield or Not to Yield to the Authority of Marrism? 99

B. An Attempt at Creating "Marrism with a Human Face" 106

5. Freidenberg's Semantic Paleontology and the History of Folklore

A. The Collective Study of the Plot of Tristan and Iseult

B. The Discussion "What is Folklore": Freidenberg, Zhirmunskii, Azadovskii

6. Freidenberg and the Formalists: The Broken Connection 131

A. A Similarity of Macrostructures and Dissimilarity of Microstructures

B. Factors, Facts, and Their Interaction within the Literary System, According to Freidenberg and Tynianov .... 136

C. Freidenberg and the Folklorists of the Formalist School: Vladimir Propp and Petr Bogatyrev

Part Four. Habeant sua fata libeli 149

7. Suppression and Release of The Poetics of Plot and Genre 151

A. Reopening the Department of Classical Studies in the Soviet University

B. Travels through the Labyrinths of Power: The Adventures of The Poetics of Plot and Genre

8. The Poetics of Plot and Genre: Content of the Book 165

A. "Dissimilarity is the Most Essential Form of Identity" ......... 165

B. Shifts in Meaning/Structure and in Image/Concept Correlations as the Main Operational Principles in the Archaic Semantics

C. Further Examples of "the Heteromorphism of the Forms of Being"

D. Forms of Comedy and Tragedy in Their Dialectical Relation to the History of Communal Perceptions

Part Five. The Siege of Leningrad and Its Aftermath 181

9. The Siege of a Human Being and the Technique of Modern Political Myths 
10. Historical Aesthetics and the Socio-Historical Method in Literature

A. "I Have Looked Biology in the Eye. I Have Lived under Stalin" (11: 2, 26 June 1945)

B. Ol'ga Freidenberg and Grigorii Gukovskii on Historical Poetics: The Collective Societal or the Socio-Historical Interpretation?

C. Freidenberg in the Late 1940s: "This is the Letter to the World that Never Wrote to Me"

11. Image and Concept: The Last Major Study

A. The Onset of the Anti-Marrist Campaign and Freidenberg's Retirement from the University

B. A New Formulaic Expression for the Antinomy of the Real and the Apparent

C. The Archaic Mimos and the Origin of Greek Comedy and Tragedy

D. Epic and Comedial Laughter or the Comical before Comedy 224

E. Freidenberg's Conception of a Pre-Aristotelian Metaphor .... 226

Part Seven. A Reassessment of Freidenberg's Theories 235

12. Freidenberg's Semantics and the Structural Approaches to Culture 237

A. Semantic Paleontology and the Semiotics of Culture 237

B. Two Scenarios of Christ's Entering into Jerusalem 245

13. The Freidenberg-Bakhtin Correlation 249

A. Freidenberg and Bakhtin on the Role of an Individual in the Social World

B. "The Birth of the Author" and "The Prehistory of Novelistic Discourse" 252

C. Discussing Laughter in its Relation to Ritual 258

D. "Events in Life" and "Events of Life" as Two Possible Ways of Combining the Outside World with a Human Being 
Ol'ga Freidenberg

Frontispiece

Mikhail Fedorovich and Anna Osipovna Freidenberg .......................... 15

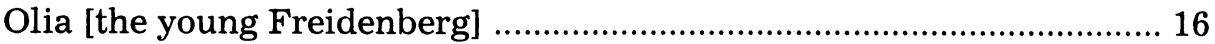

Boria [the young Pasternak] ............................................................. 16

Freidenberg as a volunteer nurse ........................................................ 42

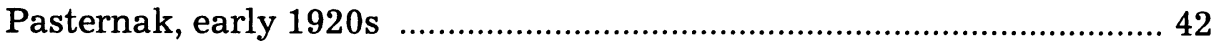

Freidenberg's teachers (N. Ia. Marr, G. F. Tsereteli,

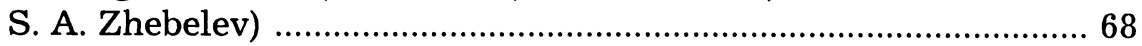

Izrail' Grigor'evich Frank-Kamenetskii ........................................... 96

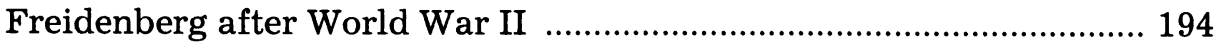

Pasternak after World War II ............................................................ 194 
W orking on this book, I was motivated by a desire to recompense Ol'ga Mikhailovna Freidenberg for a lack of like-minded colleagues and interlocutors who (under more favorable circumstances) would have emotionally discussed her innovative treatment of ancient folklore, history of culture, and historical aesthetics. I wanted to reintroduce her to the symposium of "lovers of wisdom"thinkers and scholars originating from different cultures, nations, and philosophical persuasions. Trying to organize such a "symposium" for Ol'ga Mikhailovna, however, I found myself surrounded by many friendly speech-partners and professionally involved discussants who provided me with all the necessary primary sources for undertaking my philological excavations in Freidenberg's life as a scholar. Ol'ga Mikhailovna's cousin, Lydia Pasternak Slater, and her daughter Ann allowed me to work with various unpublished documents from their family collection (Pasternak Trust, Oxford, England)-and thanks to their kindness I succeeded in obtaining more accurate information on Freidenberg's life and work. Like a fairy-tale magician, Professor Jerry Smith from Oxford University arranged for me an opportunity to copy dozens of hand-written letters that Ol'ga Freidenberg sent from Leningrad to her relatives in Oxford during the 1930s. My other colleagues-university teachers, researchers, and professional interpreters-Arlene Forman, Michael Finke, and Dobrochna Freeman, and Darra Goldstein, as well as a group of my former graduate students and nowadays colleagues-Emily Diehl, Steve Lombardo, Jennifer Day, and Vicki Polansky (who is also the editor of this book) were very helpful in "Englishing" my English. My largest debt, however, is owed to Professor Vadim Liapunov of Indiana University, and Nina Vladimirovna Braginskaia, Professor of Classical Studies at the Russian State University for the Humanities (RGGU), Moscow. Vadim Liapunov, an indisputable authority on philosophical aesthetics and the history of ideas, and a unique bilingual erudite in all areas of the humanities, generously and selflessly spent many hours with me, trying to find comprehensible English equivalents and relevant translations for Freidenberg's idio- 
matic and idiosyncratic terminology. He also provided me with continual inspiration for bringing this time-consuming study to completion, and he made for me the most desirable and encouraging critic and discussant of Freidenberg's ideas. Finally, Nina Vladimirovna Braginskaia, who is presently preparing Freidenberg's Complete Works for publication in Russia, and who has already published the main body of Freidenbeg's scholarly writings, has offered me all sorts of professional support. She was my true mentor who helped me to come out with an understanding of many of obscure terms and professional ideas in Freidenberg's texts; she shared with me all the unpublished scholarly papers that she had discovered in Freidenberg's private collections, and she also copied for me hundreds of pages of rare brochures, papers, and documents related to the years of Freidenberg's apprenticeship and then professional teaching in the Department of Classical Studies in Leningrad State University.

Publication of this book met with difficulties due to the fact that at the time I started to look for a publisher, only a very small portion of Freidenberg's texts had been translated into English. And here I would like to express my gratitude to Patricia A. Kolb, Executive Editor of Soviet Studies in Literature, who accepted for publication a collection of several seminal scholarly works by Freidenberg in English as early as 1990.

Several Short-Term Fellowships and Travel Grants Programs supported my archival research in England and in Russia and made the publication of the book possible: the 1988 GIST Summer Grant from IREX, the 1989-92 Indiana University Research Grant, and the 1992 NEH Summer Grant in Aid were of particular help to me. I thank all of my friends and colleagues who were generous in helping me find the most suitable English terms for Russian idioms, and who were tolerant enough to converse with me about Ol'ga Milkailovna Freidenberg and to listen to my descriptions of her ordeals during the horrible years of Stalin's purges, the Leningrad siege, and the antisemitic campaigns of the 1950 s.

Portions of this book have appeared in different form as an introduction to Olga Mikhailovna Freidenberg: Soviet Studies in Literature 27: 1 (1990-91); as "Elective Affinities: History of Culture in the Works of B. Pasternak and O. Freidenberg," a contribution to Indiana Slavic Studies 8 (1996, in Russian), and as "The Freidenberg-Bakhtin Correlation," Elementa: Journal of Slavic Studies and Comparative Cultural Semiotics 4: 1 (1998). 
O strange identity of my will and weakness! Terrible wave white with the seething word! Terrible flight through the revolving darkness! Stephen Spender, "Dark and Light," 1935

О вольноотпущеница, если вспомнится, О, если забудется, пленница лет.

О внедренная! Хлопоча об амнистии, Кляня времена, как клянут сторожей, Стучатся опавшие годы, как листья, В садовую изгородь календарей.

Борис Пастернак, «Душа», 1915 
(Instead of a) Preface The Existential Formula of Freidenberg's "Works and Days"

\begin{abstract}
$\int$ n 1984, while discussing the general principles of Semiotics of culture, Umberto Eco demonstrated how the Medieval Naturalists classified a unicorn within their "systema naturae": it would have been classified as vivipardae mammal, solidungulate, herbivore. Locating the species within their system with such a precise knowledge as they did, they consequently viewed the unicorn's actual presence amid the wide array of living things as an indisputable fact that would in no way rankle their minds with doubts.

Although three major monographs along with more than seventy of Ol'ga Mikhailovna Freidenberg's scholarly papers have recently become available for reassessment and fresh appreciation, an attempt to find a secure place for her ideas in our contemporary cultural context faces additional impediments unknown to medieval systematologists. ${ }^{1}$
\end{abstract}

\footnotetext{
${ }^{1}$ For a concise summary of the publication of Freidenberg's works in Russian and English, see my "Ol'ga Freidenberg on Myth, Folklore, and Literature," Slavic Review 50: 2 (1991): 371-84. Since this summary, Nina Vladimirovna Braginskaia has produced non-abridged, revised, and annotated editions of Freidenberg's three major monographs: (1) Poetika siuzheta i zhanra (Moscow, Labirint, 1997; hereafter Poetika siuzheta); (2) Vvedenie $v$ teoriiu antichnogo fol'klora. Lektsii, in Mif i literatura drevnosti (Moscow: RAN, 1998; hereafter $M L)$; and (3) Obraz $i$ poniatie, ibid. She has also published fifteen more scholarly papers from Freidenberg's manuscripts. During the 1990s a collection of Freidenberg's articles and her fundamental study, Obraz i poniatie, appeared in English translation. See Ol'ga Mikhailovna Freidenberg. Soviet Studies in Literature: A Journal of Translations 27, nos. 1 and 2 (Winter 1990-91), guest ed. Nina Perlina, trans. and ed. Jean Laves Hellie (vol. 1); ed. Anna A. Tavis, trans. Roberta Reeder (vol. 2). Although vol. 2 names me as the guest editor of the collection, I was not consulted about the accuracy of translations and am not responsible for the errors and inaccurate translations that appear in this volume. For an English translation of Obraz $i$ poniatie, see Olga Freidenberg, Image and Concept: Mythopoetic Roots of Literature, ed. Kevin M. Moss and Nina V. Braginskaia, trans. Kevin Moss (Amsterdam: Harwood Academic Publishers, 1997).
} 
Freidenberg's biography is peculiar in that it consists of many disparate parts that can be joined together only with considerable difficulty, parts that do not easily lend themselves to a rigid, systemic classification when placed in the broader context of her intellectual life. Born into an assimilated Jewish family, Freidenberg was raised in an atmosphere of highly intellectual and tolerant cosmopolitanism, yet refused to convert to Christianity and therefore was not allowed to attend the famous Bestuzhev Courses, the only institution of higher education for women in pre-revolutionary Petersburg. In 1918, having no systematicic education in Latin and no knowledge of Ancient Greek, she enrolled at Petrograd University in the Department of Classical Philology. Prior to then the department had not accepted women, and Freidenberg, with her unusual educational background, was treated as a dilettante and a half-scholar. She succeeded in learning Classical languages, but rather than ancient literatures, she chose preliterate archaic folklore as the major field for her specialization and therefore once again made herself appear eccentric (if not alien) in comparison to her university teachers and student colleagues. In addition, from the very beginning, her scholarship had been treated as a component of Nikolai Marr's theories, whose main principles she herself found difficult to accept. Because of her affiliation with Marrism, Freidenberg's scholarly ideas have been wrongly classified, the originality of her discoveries underestimated, and the entire history of her professional and administrative career misinterpreted. As Kevin Moss, the author of the Ph.D. thesis "Olga Mikhailovna Freidenberg: Soviet Mythologist in a Soviet Context," writes in the introduction to his translation of Freidenberg's Image and Concept, in 1950, when "Stalin denounced Marr and Marrism in Pravda, [t] he same association with Marr that had been a guarantee of Freidenberg's success now assured her downfall."2 Finally, there are few documents and little factual material for an unbiased intellectual biography of Ol'ga Freidenberg, and one has to rely on and to select from her own meta-critical and meta-biographical texts, such as her unpublished memoirs ${ }^{3}$ and her correspondence with Boris Pasternak. The only documentary source available in translation is Freidenberg's correspondence with Boris

\footnotetext{
${ }^{2}$ Kevin Moss, introduction to Freidenberg, Image and Concept, 1.

${ }^{3}$ Freidenberg's multivolume retrospective diaries Probeg zhizni (The Race of Life; hereafter cited by volume and page number) is held in the Pasternak family collection (Pasternak Trust, Oxford, UK). Before perestroika, fragments from The Race of Life were published in Russian in Western editions; several more appeared in Russia after 1986. See M. Iu. Sorokina, "Kratkoe opisanie materialov lichnogo arkhiva O. M. Freidenberg" ("Concise Description of O. M. Freidenberg's Private Papers") in Freidenberg, $M L, 781$.
} 
Pasternak. ${ }^{4}$ Thus as a biographical overview of an undeservedly forgotten foreign scholar, my book had, perforce, to limit its focus to elements of Freidenberg's personality and, instead, dwell on details that she herself deemed relevant over the course of her life. Yet as this critical study has been built into a cultural context, deviations from the genuine genre of biography became unavoidable. The contextual setting kept me from depicting Freidenberg in greater relief and prevented me from embarking on a discussion of the multifaceted surroundings that constituted the real cultural and historical backdrop for her works and days. This change of focus had the effect of blurring the individual traits of my central figure, Ol'ga Freidenberg, and so too did it prevent me from creating fuller portraits of her contemporaries. ${ }^{5}$

To ameliorate the deficiencies in the composition of both biographical and cultural overviews, I had to refocus my narrative and to substitute double-voiced exchanges for multivoiced discussions. I had to sacrifice complex configurations which otherwise could have been envisioned as symposia: Ol'ga Freidenberg - Vladimir Propp - Walter Ong - Carlo Ginzburg - Mikhail Bakhtin on orality and literacy; Freidenberg - Leo Spitzer - Erich Auerbach - Northrop Frye - Bakhtin on literary form and social development; Freidenberg - Lucien LévyBruhl - Claude Lévi-Strauss - Vladimir Propp on folklore and cultural and philosophical anthropology. Similarly, my study purposely omitted a comparative treatment of the agonistic factor in culture as it was distinctively conceived of by Freidenberg, Huizinga and Bakhtin. Such was the fate of any problem which might incite polemics around the dominant trends in pre-and post-structuralist criticism. All of these contextual, intertextual, and intercultural discussions will hopefully attract scholarly attention once more texts representing the various periods of Freidenberg's life are published in English and larger segments of the severely damaged cultural context of her time are restored.

The principal events in the life of Ol'ga Mikhailovna Freidenberg (born 1890 in Odessa, died 1955 in Leningrad) could easily fit onto one page. Author of a fifteen-volume memoir The Race of Life (Probeg zhizni) and

${ }^{4}$ Elliott Mossman, ed., The Correspondence of Boris Pasternak and Olga Freidenberg 1910-1954, trans. Mossman and Margaret Wettlin (New York: Harcourt Brace Jovanovich, 1982). Hereafter cited as Correspondence.

5 In addition to Mossman's Correspondence, Freidenberg's "Personalia" includes only seven biographical sources (memoirs, diaries, and letters) written by her contemporary colleagues, friends, and ideological opponents. See M. Iu. Sorokina, "Kratkoe opisanie," 771-75. References to these texts will be incorporated into the main body of my study. 
nearly a hundred valuable scholarly studies on ancient folklore and literature, daughter of a self-taught Jewish engineer, inventor, and littérateur, Moisei Fillipovich/Mikhail Fedorovich Freidenberg, niece of the famous artist Leonid Osipovich Pasternak, she was only two months younger than her world-renowned cousin Boris, with whom she carried on a correspondence for forty-five years. During her youth, Ol'ga Mikhailovna had managed by 1914 to travel throughout the greater part of Western Europe and to master nearly a dozen foreign languages. The outbreak of World War I put an end to her peregrinations.

From 1917 to 1955, Freidenberg spent her time exclusively in Petrograd-Leningrad, leaving the city only for one vital two-day business trip to Moscow. From the time she became a student at Petrograd University her works and days were dedicated solely to her profession, save for the time and care which she devoted to her mother, Anna Osipovna, née Pasternak. A born non-conformist, a person of deep emotions and strong passions, Freidenberg never shared her bed with the men she loved, did not marry, did not bear children. To paraphrase the ancient poet Hesiod, whom Freidenberg studied for many years, "works" filled the "days" of her life, "works" gave meaning to her existence.

Comparing Freidenberg's biography with the lives of those few women who began their scholarly careers at Petrograd University at the same time as her, one could still naively consider her among the exceptional few who achieved success in the post-revolutionary period. ${ }^{6}$ Indeed, Freidenberg was the first woman to receive a master's degree and subsequently a Ph.D. in Classical Philology from a Soviet university. She had the singular fortune to maintain a long, active correspondence with the Pasternak family: with "Uncle Lenchik" and his family in Europe, and most significantly, with Boris in Moscow, which provided

${ }^{6}$ Cf., for instance, Nina Viktorovna Pigulevskaia (née Stebnitskaia, 1894-1970), a Syriologist trained at Petrograd University, who was arrested in 1928 for participation in the meetings of the "Voskresen'e" circle and spent six years in labor camps and in exile. Pigulevskaia was given permission to resettle in Leningrad and work in the Public Library only in 1934. A graduate of the Bestuzhev courses, Elena Mikhailovna Tager (1894-1964), scholar, prose writer, translator, and author of memoirs on O. Mandel'shtam (Novyi zhurnal 81 [1965]: 172-99) spent a total of 20 years in prison camps, exile, and under the surveillance of the KGB. Although Tager was "rehabilitated" in 1955, her name and works were not included in Kratkaia literaturnaia entsiklopediia in 1972. For scattered information on Tager, see N. A. Zabolotskii, "Istoriia moego zakliucheniia," ed. E. Etkind, Minuvshee 2 (1986): 319, 331; S. S. Gitovich, "Arest N. A. Zabolotskogo," Pamiat' 5 (1982): 338, 343-44; 350-52; and N. I. Gagen-Torn, Memoria (Moscow: Vozvrashchenie, 1994), 328-30. 
her with much spiritual sustenance. ${ }^{7}$ Freidenberg escaped the purges and repressions, continuing to work in her field even after her elder brother's arrest and liquidation in 1937. For seventeen years she headed a scholarly collective that she had created, serving as the chair of the Department of Classical Languages at Leningrad University. In addition, she published more than thirty scholarly works, including one extensive monograph. She survived the horrors of the Siege of Leningrad and the anti-Semitic campaign against "rootless cosmopolitans" launched after World War II. Only in 1950, in connection with the linguistic campaign against Nikolai Iakovlevich Marr, did the University administration oust her from the chair and force her into retirement after she herself had virtually provoked her dismissal by refusing to denounce her former mentor. This was yet another example of Freidenberg's moral fortitude, for, during the days of Marr's ascendancy, she was one of the few who did not conceal her reservations about the validity of his "Novoe uchenie o iazyke" ("New Teachings on Language").

Outwardly, the misfortunes that befell her are common to many biographies contemporaneous to her own. In 1937 she lost the man she loved, Izrail' Grigor'evich Frank-Kamenetskii, who fell victim to a car accident, but was, nevertheless, spared the terrors of arrest and torture which befell so many of her other friends. During the war her eightyfour-year-old mother died from starvation and shock, but so too had millions of others. Despite complicated relations with her colleagues and students, she was nevertheless fortunate to have a few dedicated followers, and even those who disagreed with her have recently acknowledged her as a talented scholar.

A classicist by training, a person content by nature with limited social contacts, Freidenberg was hardly suited to the role of historiographer for the post-revolutionary epoch. However, a reading of Race of Life proves the opposite: even amidst the avalanche of recently published documents of the period, Freidenberg's notes preserve their

${ }^{7}$ An essential portion of Freidenberg's epistolary legacy (26 May 1932-9 June 1937), held in the private collection Pasternak Trust (Oxford), includes letters by Ol'ga and her mother Anna Osipovna to members of Leonid Pasternak's family. The first letter, dated May 1932, describes the acknowledgment of her academic work and the promotion given to her in April; the last letter informs of the loss of her best friend and colleague, Izrail' Grigorievich Frank-Kamenetskii (see chapter 3, 83-96). In several letters (28 January 1933, summer 1933, 15 December 1936) Freidenberg dissuades her relatives from returning to Moscow, and, using Aesopian language, depicts the horrors of everyday life under the Soviet regime. Freidenberg's contacts with her relatives in the West were interrupted by the arrest of her sister-in-law Musia, and then by the imprisonment and execution of her elder brother Sasha. 
uniqueness. In her memoirs she acknowledged the awesome power of the maelstrom into which each individual was drawn, yet she likewise makes every person responsible for their choice to swim with or against the current. In this regard, Freidenberg's Race shares many characteristic features with Herzen's My Past and Thoughts. At first glance, perhaps, such a comparison may seem inappropriate due simply to the obvious psychological differences between the two authors. Herzen was an indefatigable social activist and political polemicist, and an admired friend of such European celebrities as Michelet, Mazzini, Garibaldi, and Victor Hugo; Freidenberg was a self-absorbed, pensive loner. Resisting his own philosophical pessimism, Herzen made himself into a fighter for the future, and in the darkness of the night (as he described the reign of Nicholas I) he strove for the dawn of the new day. For him, "with the Crimean war, with the death of Nicholas a new time came on.... Overwhelmed by a feeling so unusual for a Russian, I called to mind Kant taking off his velvet cap at the news of proclamation of the republic in 1792 and repeating, 'Now lettest Thou Thy servant depart.' Yes, it is good to fall asleep at dawn after a long night of bad weather, fully believing that a marvelous day is coming!"8 Wholly aware of Herzen's way of expressing his belief that the death of the tyrant had "cast up the highway for the people" (Isa. 62:10), Freidenberg did not enter the news on Stalin's death into Race of Life; for her, the nocturnal reality of Stalinism had no end, and "the day of vengeance was in [her] heart" (Isa. 63:4).

The more distinct the dissimilarity in their epistemological views, the clearer is the realization that in organizing the textural fabric of The Race of Life Freidenberg intentionally followed the composition of $M y$ Past and Thoughts. Freidenberg's memoirs consist of several interwoven themes, the most prominent of which are provided with individual subtitles: "The Siege of a Human Being," ("Osada cheloveka") "Recollections on My Own Self" ("Vospominaniia o samoi sebe"), "The Crown of Fresh Dill" ("Venok iz ukropa"); they are also given succinct introductory passages which function as epigraphs. ${ }^{9}$

\footnotetext{
${ }^{8}$ Alexander Herzen, My Past and Thoughts, trans. Constance Garnett (New York: Vintage Books, 1974), 532. The quotation is from Luke 2:29.

9 The heading "A Wreath of Dill" originates in ancient history: the victors of the Nemean festivals were crowned with wreaths of dill (or wild celery). See Pindar, The Odes, trans. John Sandys (Cambridge: Harvard University Press, 1968), xxix, 353. Freidenberg's explanation of the title states: "And dill changes its semantics. The Greeks planted it at burial grounds. In the Soviet Pantheon, where laurel wreathed the headings of Zhirmunskii's and I. Tolstoi's monographs [Freidenberg's adversaries-N.P.], life crowned us only with dill," and she goes on to describe the inhuman conditions of life in the besieged city of Leningrad.
} 
A typical autobiography, the first volume of My Past and Thoughts provides a varied cast of characters and family histories, and in several cases the titles of the individual subchapters in Herzen's memoirs can be easily transferred to Freidenberg. As in Herzen, her "Recollections on My Own Self" offers a mix of the personal and the historical, and attains a level of interpretation which Herzen characterized as the "assimilation of the historical to the personal" (otrazhenie istorii $v$ cheloveke). ${ }^{10}$ Cataloguing the idiosyncratic features which characterize both Herzen and Freidenberg, one finds in their memoirs a combination of meditative self-reflections and ethical nonconformism, an almost religious veneration of history in which both recognized the manifestation of "an objective process above and beyond human beings" and the expression of their individual "materialistic outlook." Furthermore, both firmly believed that "the keeping of archives made [them-N. P.] members of the universal brotherhood of humanity"; 11 and both preserved in their archives many valuable facts about the history of the humanities in Russia that were rescued from oblivion. From both The Race of Life and My Past and Thoughts one learns how history works its way into a human personality.

Like My Past and Thoughts, The Race of Life was written over a number of years with substantial interruptions. Rather than fuse together her fragmented notes, Freidenberg preserved the imprint of time on each individual episode. Herzen's confessional biographical narrative was colored by a pessimistic tone, but the general metaphor determining the meaning of history did not lose its teleological nature: "We can foresee the future, because we are the premises on which its syllogism is based, but only in a general, abstract manner." ${ }^{12}$ Freidenberg, who demonstrated in her scholarship that fatalism and cyclicality were essential to the idea of ancient time, applied the mythic, eschatological formula of the cataclysm to contemporary life. She epigraphed her memoirs with a line from Pindar's Nemean Ode IV: "Well I know that the lapse of time will achieve its preordained perfection." ${ }^{13}$ Herzen's $M y$ Past and Thoughts bears a dedication to his friend Nikolai Ogarev and is epigraphed with a fragment from his poem "Humor":

\footnotetext{
${ }^{10}$ Dwight Macdonald, preface to Herzen, My Past and Thoughts, xi.

11 Mossman, Correspondence, 271.

12 A. I. Gertsen, Sobranie sochinenii $v$ tridtsati tomakh (Moscow: AN SSSR, 1954-64), 3: 233.

13 In the epigraph Freidenberg quoted this line in the original Greek. In The Race of Life (4: 63-65), Freidenberg included a summary of her paper "The Teaching of the Greeks about the Upheaval" ("Uchenie grekov o perevorote"), delivered in January 1928 at a session of "The Society of Marxists" in LOKA (Leningrad Department of the Communist Academy).
} 
When memories of the past return

And the old road again we tread,

Slowly the feelings of old days

Come back to life within the soul...

Когда мы в памяти своей

Проходим прежнюю дорогу,

В душе все чувства прежних дней

Вновь оживают понемногу... ${ }^{14}$

As memoirists, both Herzen and Freidenberg made their personal archives representative of their own particular views on history; they doubted the efficacy of any individual attempt to apprehend the future or to act with any significant degree of assurance in relation to it, yet charged humans with moral responsibility for their choices and how they enact them. With no hope left for an optimistic outcome of an individual existence, both maintained that a preordained superpersonal destiny finds its realization. The typological affinities between The Race of Life and My Past and Thoughts constitute two overlapping planes: the sensation of the appalling corruption of human and humane rights as testimony to the apocalyptic character of their epochs; and an inherent conviction about the extratemporal validity of the writer's own individual, personal existence. Both authors (Herzen and Freidenberg) treated this side of their personalities as an inherently existential feature rather than a distinctive quality acquired by them either through their family upbringing or education.

A thorough, comparative study of Freidenberg's and Herzen's memoirs and a discussion of the place the texts occupy in the cultural awareness of their epochs has yet to be undertaken. In this discussion, emphasis will be given to two groups of juxtapositions: one, political exile and internal emigration, or to be more precise, the common basis of socio-political and individual ethical nonconformism; and two, the universal and the specific as the foundation of participative philosophical thinking. Such a comparative interpretation might result in a reenhanced notion of the private archive without ever obliterating the characteristic features of a literary and trans-historical genre without ever obliterating the archive's inherently individual and familial traits.

As in My Past and Thoughts, the personal and intimately biographical slant in The Race of Life is given an additional epigraphic foreword:

My life is described by Maupassant in Mont Oriol in the tale of a little donkey. It was from there that I laid the groundwork for

14 Gertsen, Sobranie sochinenii, 8: 13. For an English translation, see Herzen, $M y$ Past and Thoughts, 2. 
the course that my life would take thereafter. Apparently that is why algebra exists, in order to be concreticized by every individual arithmetical expression.

Моя жизнь описана Мопассаном в «Монт Ориоле» в истории ослика. Я спланировала ее жизненный процесс оттуда. Повидимому, алгебра для того и существует, чтоб каждый из арифметических случаев конкретизировал ее. (1: i)

The aphorism that Freidenberg inserted into the preface to her memoirs refers to the picnic episode in Maupassant, which she interprets as a metaphor for the burden of living. ${ }^{15}$ With this aphorism then attached to her manuscript (on 6 August 1947) she was to continue her memoirs as a kind of retrospective diary for three more years. On 10 December 1950, with the entire work completed, she epigraphed the text with the line from Pindar's Ode. One feels puzzled by the linkage of the two aphorisms, for, if the meanings of the inscripts dovetail, the algebraic expression of Freidenberg's life should read: the story of a donkey = fulfillment of human destiny. ${ }^{16}$

The Mont Oriol episode in Maupassant provides the metaphor for the burden of living:

The merry little donkey, with his big head and a pair of big shining eyes, clumsy and good-tempered, with his rough hair and his long ears, gamboling about, still free, close to his mother's legs; then the first cart, the first uphill journey, the first blows; and after that, the ceaseless, dreadful dragging along interminable roads; the overpowering heat of the sun, and nothing for food save a little straw, a little hay or some branches $\ldots$ and the frightful martyrdom of the animal, worn out, bereft of breath, bruised, always dragging after him excessive loads... And then the death, the beneficent death, three paces away from

15 For an English translation, see Guy de Maupassant, Mont Oriol and Other Stories (New York: National Library, 1909), 247.

${ }^{16}$ Similarly, in his "Dedication to Nikolai Platonovich Ogarev," looking back to their "works and days," Herzen writes: "Life ... lives, peoples, revolutions, beloved faces have appeared, changed, and vanished between the Sparrow Hills [in Moscow, where he and Ogarev were born-N. P.] and Primrose Hill [in London, where they lived in exile-N. P.]; already their traces have almost been swept away by the pitiless whirlwind of events. Everything round me is changed: the Thames flows instead of the Moscow River, and I am surrounded by a strange people ... and there is no more a way for us back to our country.... May my Past and Thoughts settle my account with personal life and be its summary." Herzen, My Past and Thoughts, xlix. 
the grass-grown ditch, to which a man, passing by, drags him with oaths, in order to clear the road. ${ }^{17}$

Thus, rather than fitting together to form one piece, the epigraphs frame the narrative and represent ultimate landmarks of the allegorical space. The existential formula of Freidenberg's "works and days" can be rendered as "The obligation to fulfill human destiny despite the blows of fate and unspeakable sufferings." One finds this expression in her diary entry for 28 March 1947, the date of her fifty-seventh birthday, when, in a state of a deep depression, she listened to a radio program about Beethoven, who endured even when he became totally deaf...

Suddenly I heard the phrase: "Despite his sufferings, Beethoven fulfilled his human destiny." I stopped, shaken. Yes, this is pure space talking through a megaphone. This I understood. This was not the will to live, this was the dignity of a human. The human follows his path to the end. He remains himself despite everything, as if he were to state: "I do what I must, the way I understand my duty. The rest does not concern me. You may strike me down, but I am still a human being..." Why was it impossible for me to live up to this?

Вдруг я услышала фразу: «Бетховен, несмотря на свои страдания, осуществлял человеческое значенье». Я остановилась, потрясенная. Да, так говорит в рупор чистое пространство. Это я поняла. Это не добродетель, не сила жизни, а гордость человека. Он идет своим путем. Он остается собой, не глядя ни на что. Я делаю свое дело, так, как понимаю его. Остальное меня не касается. Бей меня в грудь. Я продолжаю быть человеком. Почему же я не могла воспрянуть? (12: 2: 23)

And Freidenberg lists the blows of fate and the "ultimate depth of despair" of her own existence: the arrest of her brother Alexander; the valenki (felt boots) and rubber boots purchased for him - "the admonition before his deportation" (naputstvie pered ugonom po etapu) which remained undelivered, and then the siege:

No, only a living soul can rise up. Those who are dead are not resurrected. Deaf, as he was, Beethoven heard harmonies within him.... From childhood, ardor for the Absolute was my element-ardor for great love, for life, for truth, for God. The tragedy is that the siege killed this passion... Deafness from within! Was Beethoven aware of the ultimate depth of despair? 
Нет, подняться может живая душа, мертвые не воскресают. Бетховен и глухой слышал вокруг себя созвучья. Страсть $\mathrm{k}$ абсолютному была моей главной сутью с детства - к любви; но большой, к Жизни, к подлинному, к Богу. Моя главная драма в том и состоит, что осада убила ее.... Изнутри глухота! Знал ли Бетховен последние пределы отчаянья? (12: 2: 23-24)

In Freidenberg the "siege" covers time, space and experience in a sense far wider than anything encompassed or comprehended by any single survivor of the Leningrad blockade. The title Osada cheloveka, given to volumes 7-12 (June 1941-summer 1945) means both "The Siege of a Human Being" and "The Siege of Being." The siege on the lives of those who were doomed to endure Stalinism had been declared prior to the onset of the war and was never to be lifted. On the last page of her notes Freidenberg states that the most terrible thing that she had witnessed was "the siege, the scalping of a living human being which not a single soul can endure.... I don't know when and how I will die. I only know that if I am conscious, two images will stand before my eyes, that of my mother and of the Moscow Nuremberg" (15: 154).

Freidenberg envisioned "The Moscow Nuremberg Trial" as an image-concept comparable only to the day of the Last Judgment, when "the lapse of time will achieve its preordained perfection." Wholly aware of the significance of this super-historical context, Freidenberg treated her memoir notes as the fulfillment of an idea conceived by history itself. Like Herzen, whose memoirs were also motivated by his understanding of preordained fulfillment in history and time, Ol'ga Freidenberg chose to incorporate into her autobiographical notes a wide range of discrete texts: humorous domestic verse and intimate letters; summaries of her presentations at various academic meetings; appeals addressing the top figures among the "apparatchiks"; information on the prices of rationed bread in blockaded Leningrad; letters from relatives and from former school friends, and, of course, ample information on ideological purges, political campaigns, their instigators, executioners, and victims. Like Herzen, Freidenberg chose to build these sundry documents into her Race of Life in order to settle her account with history and to provide its summary through an overview of her personal life. She had bequeathed to posterity her writings, which were, in her words, "no less terrifying than the Egyptian Book of the Dead."

It might appear at first glance that Ol'ga Freidenberg's attitude towards her own writings (both her biographical notes and professional scholarship) differed remarkably from that of Boris Pasternak towards his own materials for creative writing. In a letter to Maria Markova, his and Freidenberg's cousin in Leningrad who was with Ol'ga Mikhailovna at her death bed, Pasternak wrote: "Olya was the keeper of family tra- 
ditions, of letters and mementos.... I personally do not keep heirlooms, archives, collections of any kind, including books and furniture. I do not save letter or draft copies of my work. Nothing piles up in my room; it is easier to clean than a hotel room. My life resembles a student's." ${ }^{18}$ In his poem "Byt' znamenitym nekrasivo" Pasternak wrote caustically about the redundantly overestimated values ascribed to the archives and creative legacy of poets: "Ne nado zavodit' arkhiva, nad rukopisiami triastis." ${ }^{\prime}$ Pasternak by no means utterly adhered to this poetic credo; as Evgenii Borisovich Pasternak has proven, many valuable documents and poetic drafts were preserved in his father's archive. ${ }^{20}$ Thus the problem of common familial features cannot be treated in a straightforward, normative fashion. Biographically, Ol'ga Freidenberg and Boris Pasternak hardly share many common familial features; their perception of reality, however, can be characterized by Goethe's definition "Wahlverwandtschaften," or "elective affinities."

\footnotetext{
18 Mossman, Correspondence, 12.

19 Boris Pasternak, Sobranie sochinenii $v$ piati tomakh (Moscow: Khudozhestvennaia literatura, 1989; hereafter $S S$ ), 2: 74.

${ }^{20}$ E. B. Pasternak, Boris Pasternak: Materialy dlia biografii (Moscow: Sovetskii pisatel', 1989), 6-8.
} 


\section{Elective Affinities}

Боря очень нежный, но я его не люблю. Тетя всегда шепчется с дядей и мамой, и есть слух, что мне придется выйти за него замуж. Это меня возмущает. Я не хочу за него. Я хочу за чужого. Но Боря любит и прощает.

Ольга Фрейденберг, Пробег жизни 


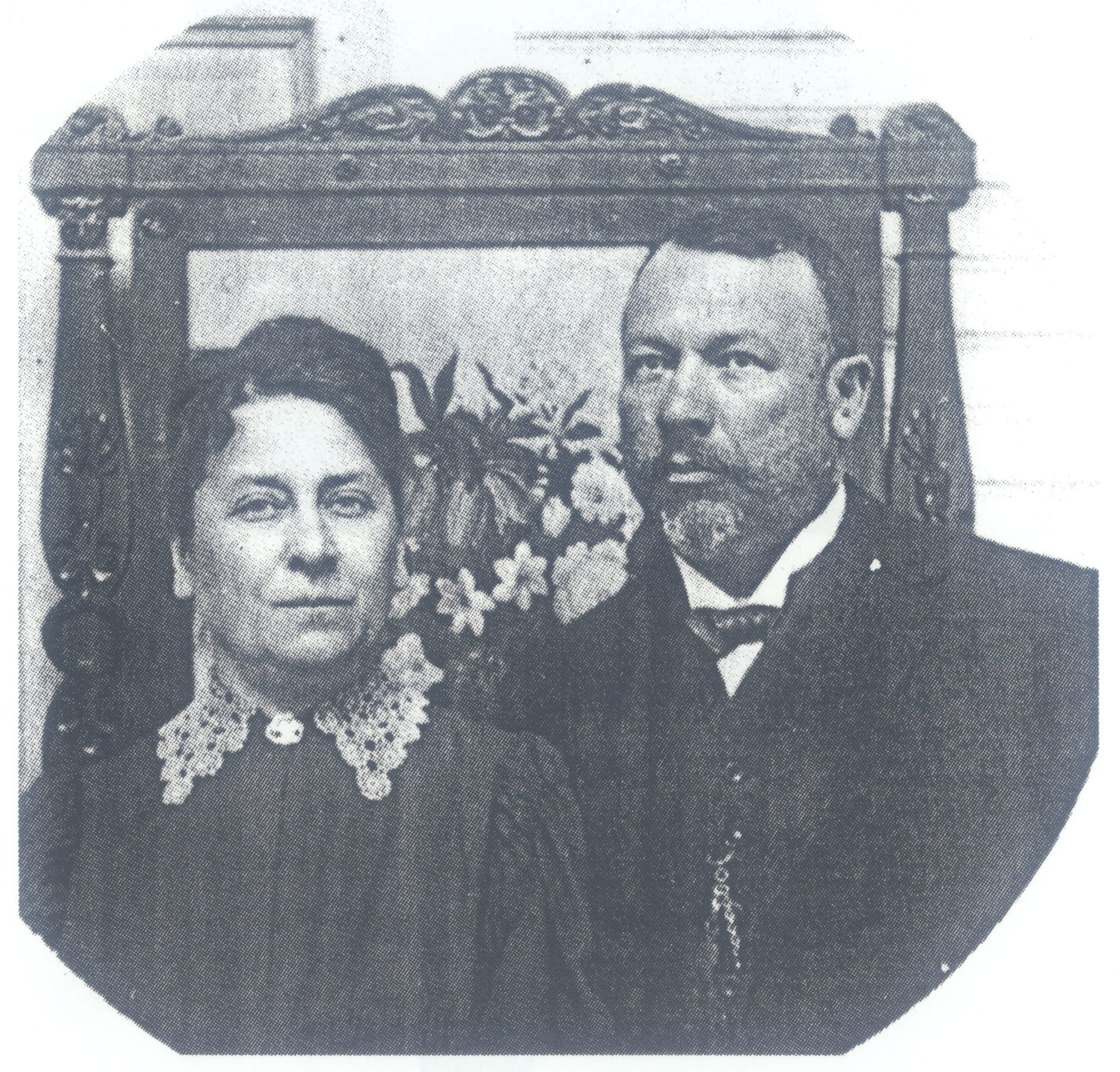

Mikhail Fedorovich and Anna Osipovna Freidenberg 


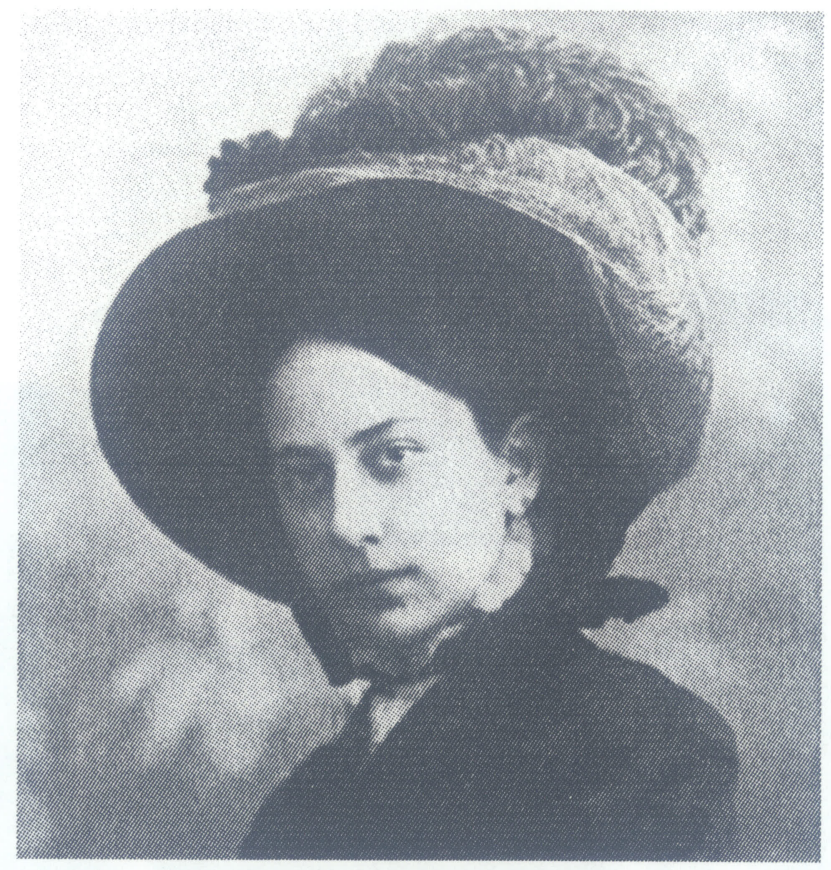

Olia

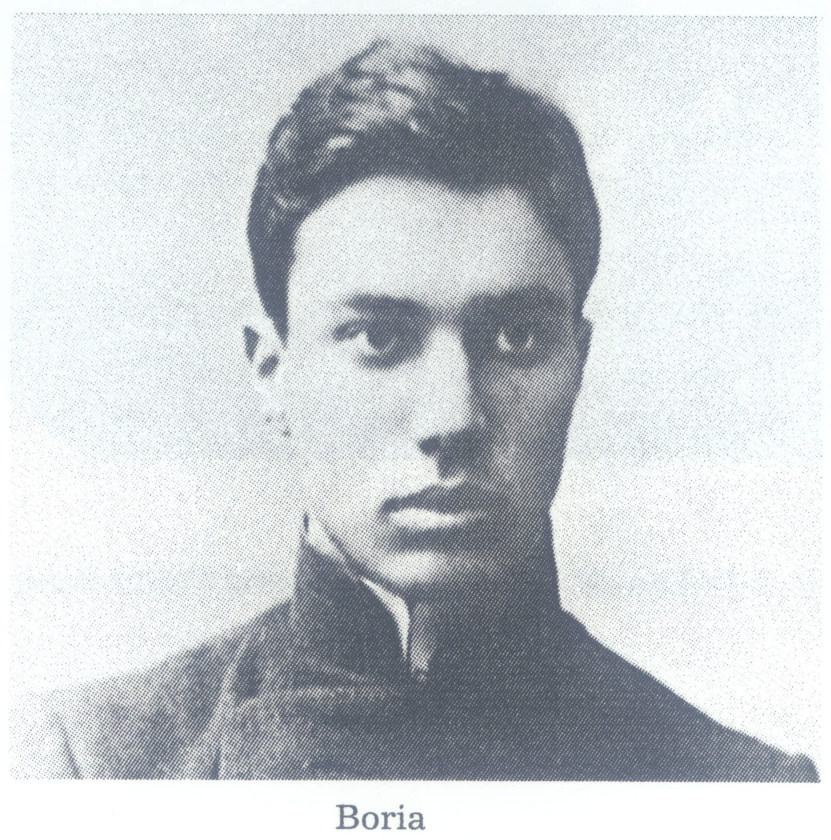


Chapter 1

\section{Ol'ga Freidenberg and Boris Pasternak on Their Personal Experience and on Cultural Values of Their Time}

\section{A. Recollections of Childhood and Youth: Composition of the Narrative}

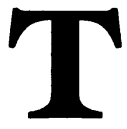

he individual volumes of The Race represent the various epochs of life. Accordingly, each volume has its own internal logic, its own language, and its own boundaries in respect to the cultural and epochal horizon under consideration. Volumes 1 and 2, which talk about childhood and youth (both in terms of age and in terms of professional development, the entry into a scholarly life), have a unique composition and are marked by a unique intonation. These volumes present an additional interest for those studying the creative work of Boris Pasternak; they encompass both those years marked by frequent meetings and an intense correspondence between Boris Leonidovich and Ol'ga Mikhailovna, and that time when their correspondence all but ceased due to a misunderstanding that took place in 1912 and again later as a result of the postrevolutionary destruction. The chronological boundaries of the first volume are from the beginning of the century to the end of 1917; for the period between 1910 and 1913 , seventeen of Pasternak's and thirteen of Freidenberg's letters have survived. The chronological boundaries of the second volume, 1918 to 1923 , may be supplemented only with two of Boris's letters written in 1921, from which it follows that during the summer of that year he had received a "derisive and cruel" letter from her. On 16 June 1922 Pasternak sent his book of verse My Sister Life (Sestra moia zhizn) to Petrograd with the tender dedicatory inscription: "To my dear sister Olechka Freidenberg from ardently loving you Borya."1

\footnotetext{
${ }^{1}$ Mossman, Correspondence, 60. For letters, dedicatory inscriptions, and family photographs of the period 1910-24, see ibid., 1-90. Contacts with the Freidenbergs' Moscow relatives were severed during these years at the initiative of Anna Osipovna, who could not forgive her brother Leonid that after her husband's death (1 August 1920) he had not stopped in to bid her farewell "upon legally forsaking Russia" (ibid., 58). The intensive correspondence between Boris Pasternak and Ol'ga Freidenberg resumed in 1924.
} 
The chapters of the first volume of Freidenberg's memoirs read as a parallel to the events in the life of Boris Pasternak and his family. The Freidenberg and Pasternak families were tied not only by kinship but also by the close friendship of the fathers, mothers, and children. Ol'ga Mikhailovna's mother, Anna Osipovna (1862-1944), was the favorite sister of the artist Leonid Pasternak. In 1932 he addressed her in his autobiographical notes: "Dearest sister, Asia! You are the only member of our large family still alive. You alone, my companion and faithful friend, you alone remember the strange things which happened while I was still in my cradle."2 Leonid Osipovich called the husband of his sister Asia, Mikhail Fedorovich Freidenberg, "the best friend of my youth" and wrote that he owed much to Mikhail Fedorovich for the contribution he made to his artistic development. ${ }^{3}$ In recollecting her childhood, Ol'ga Mikhailovna finds there are "two mothers, mine and theirs" (1: 5). Houses, brothers, sisters, uncles, and aunts were both Freidenbergs and Pasternaks for her: she remembers her childhood against the background of the picturesque canvases of "Uncle Lenchik"; she experiences her adolescence in hues that are colored by Boris's poetic vision. For example, about her older brother Sasha she writes: "A handsome, purebred face and light blue eyes reminded one that he was a Pasternak. I am sure that even then one could have guessed that he would not get along with life and would turn into one of those Pasternaks who rather resembles a literary personage more than a real person. He was completely original, without a drop of banality, and was the representation of Boria's poems in the guise of a living person" (1:20).

Unlike the first volume of the memoirs, in the second some chapters give a cultural-historical background and others ethically and psychologically supplement and decipher the meaning of Pasternak's writings from the end of the $1910 \mathrm{~s}$ to the $1920 \mathrm{~s}^{4}$ As we know, in Safe Conduct chapter 11 of part 2 and the concluding chapter of part 3 create a symbolic picture of the moribund world of human culture and of two men who are inseparably connected with this world. Postwar Germany and Hermann Cohen (who died in 1918) are the subjects of the eleventh chapter, and chapter 17 centers on the figure of Vladimir Maiakovskii (who committed suicide in 1930) and the Soviet state, in which "in its

\footnotetext{
2 Leonid Pasternak, Memoirs, trans. Jennifer Bradshaw (London: Quarter Books, $1982), 16$.

3 Ibid., 29-30.

${ }^{4}$ Ol'ga Freidenberg's last meeting with Boris Pasternak took place in Moscow in November 1936. On the content of the "cultural-historical dimension," see B. Gasparov, "Poetika Pasternaka v kul'turno-istoricheskom izmerenii (B. L. Pasternak i O. M. Freidenberg)," Sbornik statei $k$ 70-letiiu prof. Iu. M. Lotmana (Tartu: Tartusskii universitet, Kafedra russkoi literatury, 1992), 366-84.
} 
palpable extraordinariness ... there was something that resembled the dead man." About the "decline of the West" the poet speaks in prose:

Six years passed. When all was forgotten. When the war had dragged by and come to an end and the revolution had broken out. When space, which was previously the homeland of matter, took ill with gangrene of fictions of the rear [gangrena tylovykh fiktsii] and proceeded with fading cavities of abstracted nonexistence. When we were exhausted by the fluid tundra and our soul was beset by a lingering, tinkling governmental rain [zatiazhnoi, drebezzhashchii gosudarstvennyi dozhdik].... I had seen Germany before the war, and now I was seeing it after. What had happened in the world appeared to me in the most terrible foreshortening... Germany was hungry and cold, deceived about nothing and deceiving no one, her hand outstretched to the ages for alms (a gesture not characteristic of her), with the entire country on crutches... And now about Cohen. I could not see Cohen. Cohen was dead." ${ }^{6}$ In the West Cohen had died, a man who represented the spiritual landscape of Germany, and in the Soviet world Maiakovskii committed suicide-"a man [who] was, strictly speaking, the only citizen of this state community."7

In the second volume of The Race, Freidenberg recounts with great precision each of these symbolic signs from the autobiographical prose of Safe Conduct. While in themselves possessing a cultural-historical value, her reminiscences in their content, in their style, and in their very way of experiencing her surroundings colorfully set off (and make more perceptible) the particular features of Pasternak's artistic vision. She describes in detail the real physical, as well as spiritual and ethical, illnesses of people of the older generation (her father's fatal illness and the death of her university teacher, the Slavist Professor Borozdin). Everything that in Pasternak is designated by "fading cavities of abstracted nonexistence" is unfolded by her into a detailed picture of the trivialization of the spiritual forces, the academic dignity, and the human self-esteem of the old intelligentsia. She writes with temperament and without fear about the misfortunes that she and her widowed mother had to endure and describes in detail the destructive and inhuman nature of the new state.

Everything in Pasternak's early story "Aerial Ways" or in Doctor Zhivago that constitutes a multilayered description is presented in Freidenberg's memoirs with chronological continuity and is unfolded

\footnotetext{
${ }^{5}$ B. Pasternak, $S S, 4: 239$.

${ }^{6}$ Ibid., $195-97$.

${ }^{7}$ Ibid., 239.
} 
layer by layer. We watch several generations of the intelligentsia live through the ordeals of two destructive wars and observe how their fates are impacted by the catastrophic events of Revolution, Bolshevik transformations, political purges, and ideological check-ups and "discussions."

As a private person and memoirist, the last thing Freidenberg saw in her retrospective diaries was a biographical or historical commentary on the work of Pasternak intended for future researchers. Working on The Race of Life, she liberated the text of her reminiscences, to the extent that this was possible, of episodes that coincided directly with Pasternak's autobiographical prose and poetry. ${ }^{8}$ For example, in presenting the story of their Platonic romance of 1910 , she included in The Race fragments from Pasternak's letters to her of 1, 7, and 23 March and 28 July 1910, but omitted the texts of his poems "Mad and greedy from insomnias" ("Bezumnyi, zhadnyi ot bessonnits") and "Behind them five blind checkpoints" ("Za nimi piat' slepykh zastav"), to which the letters served as a direct autocommentary. ${ }^{9}$ Out of a sense of dignity, she remained silent in her autobiographical sketches about their deep personal intimate feelings. What is not indicated in The Race are the words of the dedicatory inscription left on the collection Twin in the Stormclouds (Bliznets $v$ tuchakh): "To dear Olya with love and gratitude for one summer meeting ... until our next meeting on a page like this. 20.12. 1913."10 Pasternak has in mind the meeting with Ol'ga in June 1912 in Frankfurt, but he connects reminiscences of the summer of 1910 with this event. "The page" of the collection on which "the next meeting" is set is most likely the poem "The Station" ("Vokzal," 1913) as well as an early prose fragment "Most likely, I am telling a fairy tale" ("Veroiatno, ia rasskazyvaiu skazku," 1911), which remained unknown to Freidenberg. ${ }^{11}$ Their meetings in Merrekuhl, Petersburg, and Frankfurt and their subsequent travels together in Italy with Pasternak's family are described in Freidenberg in such a way as to

${ }^{8}$ Similarly, Pasternak, taking into consideration his cousin's emotional state of mind, avoided the features of real biographical similarity between the life of Ol'ga Freidenberg and the fates of his heroines Stomina ("The Beginning of the Novel about Patrick" ["Nachalo romana o Patrike"]) and Antipova (Doctor Zhivago). He created the story about the Meliuseevo romance between the nurse Antipova and Iurii Zhivago out of poetic elements that bore no resemblance to the story of the ill-fated but dramatic love of Ol'ga Freidenberg and the officer Ivan Ivanovich Dmitriev, who was undergoing treatment in the hospital where she was a nurse during the German war.

${ }^{9}$ B. Pasternak, SS, 1: 579, 587.

${ }^{10}$ Mossman, Correspondence, 46.

${ }^{11}$ B. Pasternak, SS, 1: 433, 4: 749-51. 
avoid repeating details known from Pasternak's poems (such as his "Soul," 1915) and autobiographical stories. Freidenberg laconically replaces a retelling with the sentence: "He later describes this meeting in Safe Conduct" (1:11). On the whole, traces of literary work on the text, on the selection and editing of material, are distinctly visible in The Race of Life-a work whose genre combines elements of both memoirs and confessional prose.

If one recognizes certain characteristics of a novel (a novel of ordeal or a Bildungsroman) in Freidenberg's autobiographical notes, then both her attraction and her opposition in relation to Pasternak's early prose become obvious. The affinities relate to the description of nature, local color, and details around her, as well as to the stylized depiction of her own conduct. To Pasternak's novella "The Mark of Apelles" ("Apellesova cherta," 1915, published 1918), The Race adds a number of psychological perspectives as well as observations on the surrounding landscapes. These include: "Only Boria kept himself aloof. He apparently was experiencing some great spiritual growth, while I-what was I compared to him? He had nothing to talk to me about. In the evenings, the black Italian night would fill with unusual music-that would be him improvising," as well as the rather deliberately simplistic story of how she and Boria had gone

to see Pisa - the cathedral, the tower, the famous leaning but not falling column, about which it is not known whether it was falling or was intentionally built that way. I wanted to see it and go on, to take in an impression of it and forget it... Boria, on the other hand, with a guidebook in his hands, painstakingly studied all the details of the cathedral. (1: 114)

The action of Pasternak's novella "The Mark of Apelles" begins in Pisa, and the hero of the novella is Enrico, Heinrich Heine, the author of Travel Sketches. Those who read the first volume of The Race of Life as a fragment of a novel of ordeal with a plot formed by an escapade of adventures will find particular relevance in those chapters concerning Freidenberg's European trip as well as in those details through which she alludes to imaginary thematic clusters of events that do not turn into a biographical or poetic plot in her "travel sketches." Yet rather than travesty Pasternak's motifs of an imaginary journey, Freidenberg parodies her own predilection to "finality" in biographical plot lines. The chapters of The Race describing the summer of 1912 include the motif of a journey as an amorous adventure: "a heartbreaking romance with a handsome Italian as the hero, a lawyer called Vincenzo Perna from Padua." Quite in the style of the relationship of Pasternak's heroes, Heine (Enrico) and Camilla (Rodolphino), the dénouement of the pseudoamorous relationship in Freidenberg is hastened by an impertinent let- 
ter: "I was infatuated by him. But I could not get by without some misbehavior. Since I like finality in my plot lines, I replied to him from Petersburg that I was thankful to him, but that he was a pleasant episode for me in which I had put my trust in life to the test" (1: 112-13).

In Pasternak's early prose, on the other hand, several fragments, especially those not included in the definitive text of "Zhenia Liuvers's Childhood" ("Detstvo Liuvers"), give the impression of being quotations selected from the first volume of The Race of Life and from the letters of the young Olia Freidenberg. ${ }^{12}$ As proof, it suffices to cite two pairs of excerpts from The Race of Life and from the fragment that was not included in part 3, chapter 3 of "Zhenia Liuvers's Childhood."

Freidenberg: My "cosmism" extends from my childhood-it is a feeling of being connected with everything and every one, with an unlimited readiness to fall in love and surrender myself, with an endless sense of fraternity with people and things. I absorb the world with passion, and my blotter of a soul is filled with ink spots and blotches. I love all points of view, all landscape styles, people of all nationalities and temperaments. I understand everything.

Youth would add to this heightened sensibility a passion for reworking perceptions. For the time being, however, there is a contradiction between feeling and mind: a slow and impoverished mental development with an early embracing of everything by the senses. I experience everything pensively and intensively; my chest inhales the smell; that which is seen and heard resounds with a resonant echo, broadens the personal, pushes it aside, and enters inside it in order to remain there in the form of a strong and triumphant reflection.

Мой “космизм" тянется с детства - это чувство связи со всем и всеми, с бескрайней готовностью полюбить и отдаться, с безграничным братством к людям и вещам. Я впитываю мир со страстью, и моя душа промокашки полна чернильных пятен и клякс. Я люблю все точки зрения, все стили пейзажа, людей всех национальностей и темпераментов. Я все понимаю.

Молодость прибавит к этой повышенной впечатлительности еще и страсть к переработке восприятий. А пока противоречие чувства и ума: медленное и обедненное умст-

12 The autograph of "Detstvo Liuvers" is kept in RGALI (f. 379, op. 1, no. 25). The seven fragments not included in the definitive text of the story were published by L. Fleishman. See his Stat ' $i$ o Pasternake (Bremen: K-Presse, 1977), 118-29. 
венное развитие, при раннем охвате всего чувством. Все задумчиво и углубленно переживается; грудь вдыхает запах; виденное и слышанное звучит гулким отзвуком, раздвигает личное, отстраняет его и входит, чтоб остаться в виде сильного и побеждающего отображения. (1:19)

Pasternak: (describing the characters of Serezha and Zhenia Liuvers): The sharp difference, which did not linger to find its expression at the time in the characters of the brother and sister, deepened and separated them from each other. It manifested itself in everything. Like everything human, it had more than one thousand instances of making itself known in more than one thousand forms. And, like everything human, this difference had a single root. It consisted in the fact that we will call the girl's imagination cosmogonic, while the boy had a mundane imagination.

With the girl, time and again, for the umpteenth time in the universe, the old world was created anew according to the old plan.

With the boy, the created world remained in its place, remained untouched, remained the same as it appeared to a multitude of people all at once...

Резкое различие, не замедлившее об эту пору сказаться в характерах брата и сестры, углублялось и их друг от друга отдаляло. Оно проявлялось во всем. Оно, как и все человеческое, имело не одну тысячу случаев сказаться не в одной тысяче форм. И, как все человеческое, различие это имело один корень. Оно заключалось в том, что фантазию девочки мы назовем космогонической, у мальчика же было обиходное воображение.

С девочкой снова и снова, в который уж во вселенной раз, сызнова по старому плану творился старый мир.

С мальчиком твореный мир оставался на месте, оставался нетронутоставался таков, каким он представляется множеству людей сразу.... 13

Freidenberg: A disorganization of forces, Tiutchev's "chaos," "primordial chaos, my own," whose "dormant storms" should not be awakened, but life would wake them; desires, locked in the stalls of measured and legalized weekdays-all this turned my self-absorption and cohabitation with my own self to dust, because always, at all decisive moments, I acted unexpectedly

${ }^{13}$ B. Pasternak, $S S, 4: 780-81$. 
for myself. Not all sides of my soul had in those years yet found expression. But even then, love for all the colors of life and an inner attention to all its various hues alternated in me with a passionate intolerance, with momentous fits of the destitute of sight, obscured by passion, with a rebellious screaming, and with excessively enflamed hatred. My father could not stand this in me. Neither he, nor my brother, nor Boria had this, to say nothing of the serene soul of my uncle.

Неорганизованность сил, тютчевский "хаос", “древний хаос, родимый" “уснувших бурь”, которые не следовало будить, но жизнь будила; желания, запертые в стойле размеренных и узаконенных будней - это все обращало в прах мои самоуглубления и сожительства с самой собой, потому что всегда, во все решющие моменты, я поступала для себя неожиданно. Еще не все стороны души находили в эти годы выраженье. Но и тогда любовь ко всем краскам жизни и внутреннее внимание к различным ее оттенкам перебивалось у меня страстной нетерпимостью, резкими выступами затемненной от страсти слепоты, кричащим бунтарством, слишком воспламененной ненавистью. Отец терпеть этого не мог во мне. Этого не было ни в нем, ни в брате, ни у Бори, тем паче ни в светлой душе дяди. (1: 116)

Pasternak: The girl's imagination was fatally cosmogonic. It was an enslaved, captured part of her spirit, because, when the world once again creates itself from its parts and elements together with man, then, just as at that unthinkable, mythical, first time, now, too, this world being created, and man along with it, cnce again has no will of its own. It is all once again-in the fresh, as if debuting again amidst chaos, fascinated-persistent and inspired-confident will of God.... For the girl, mystery was a word that did not exist in her dictionary; that she despised since childhood; with which, had she loved it and used it, she would certainly have designated the elemental force of every fact, that is, the massiveness of life, the fact that it is not fictitious.

Воображение девочки было космогонично фатально. Оно было крепостной, подневольной частью ее духа, потому что когда с человеком вместе вновь собирается мир из своих частей и составов, то, как и в тот немыслимый, мифически первый раз, так и в этот, у строящегося мира, а с тем вместе и у человека опять никакой своей воли нет. Он весь опять - в свежей, как бы дебютирующей среди хаоса, увлеченноупорной и вдохновенно-уверенной воле Божьей....

Для девочки тайна была словом, которого не было в ее словаре; которое она ненавидела с детства; которым, люби 
она его и пользуйся им, она наверное обозначила бы стихию всякого факта, то есть массивность жизни, то, что она - не вымышлена. ${ }^{14}$

The publication of The Race of Life will make it possible to reveal the more complex correlation between this text and Pasternak's early prose and will help elucidate the poorly studied aspects of the literary style of the epoch. ${ }^{15}$ With the publication of The Race of Life, it will be possible to demonstrate that Pasternak's early prose contains the archetypal, "primary" mythological metaphors of the assimilation of the world by a naive perception (in the story about Zhenia Liuvers-by the perception of a child) not yet touched by analysis. Freidenberg wrote much about this type of perceptual understanding of the universe, and she also applied the archetypal mythological metaphors to the foundations of her scholarship. Stubbornly and persistently, from the day of her first university reports and term papers, Freidenberg called her method genetic, with a stress on the moment of coming into life, of initial conception, of directing the archetypal focus onto the cognizing consciousness. And coinciding with this approach was a comprehension of inner meaning in her surroundings. In her scholarly works, Freidenberg concentrated her attention on the archaic folklore of the preliterary period, on those epochs of the development of culture about which information can be gained as if intuitively, through empathy into an unknown world full of primary sense-concepts not yet named by anyone. And in her memoirs, in connection with the understanding of her own personality, her "I," she wrote:

Some kind of internal rhythm, unspoken but powerful, always corresponded to me. And this rhythm of childhood, even of the coming into existence, the rhythm of "I" clad in bones and flesh, sounded inside me until the day I found it expressed outside me in Boria's verses many years later. This is difficult to articulate and to describe; but I understood it in poets the way normal people understand language; while in Boria this pure rhythm, in words or without words, sang with mathematical-musical precision about birth and about the earliest, primal, primordial childhood.

\footnotetext{
14 Ibid., 781.
}

${ }^{15}$ For the first attempts of this type of analysis of Pasternak's early prose, see Anna Ljunggren, Juvenilia. Boris Pasternak. 6 fragmentov o Relinkvimini (Stockholm: Almqvist \& Wiksell International, 1984); Christopher Barnes, Boris Pasternak: A Literary Biography. Volume 1. 1890-1928 (Cambridge: Cambridge University Press, 1989), 100-06, 145-46. 
Мне всегда сопутствовал какой-то внутренний ритм, невысказанный, но властный. И этот ритм детства, даже рождения в мир, ритм "я", одетого в кость и в тело, звучал во мне до того дня, как я нашла его извне выраженным в стихах Бори много лет спустя. Это трудно рассказать и определить; но я его понимала у поэтов, как нормальные люди понимают язык; у Бори же чистая ритмика, в словах или без слов, с математически-музыкальной точностью пела о рождении и глубоком, первом детстве. (1:115-16)

Our extensive citations from Freidenberg's and Pasternak's manuscripts do not seem superfluous. The citations demonstrate that the concepts "prototype" and "influence" are not applicable to a description of Pasternak's creative method and to the specific nature of Freidenberg's perceptions of historical and biographical thinking. It is evident that Freidenberg's self-reflection leads her to the same vision of the world as Pasternak's poetic reflection. As Boris Gasparov contends, both in Freidenberg and in Pasternak biographical facts transcend the limits of personal experience; they enter into the composition of a broad picture of the universe and lend themselves to a specific cultural-historical interpretation. ${ }^{16}$ This convergence between Pasternak and Freidenberg in their relation to reality (for both reality is "broader than life") allows one to speak about unique interpersonal or, using an expression borrowed from Goethe, "elective affinities," unfolding on a common cultural-historical background. These elective affinities, this inner closeness, growing ever closer as their direct contacts became more limited, strikes one in reading the second volume of The Race of Life.

The events that Freidenberg describes in the second volume are a direct continuation of the content of the first: "Devastated, unclothed, I entered the university" (1: 184); "I entered Petersburg University without having any scholarly or professional intentions" (2: 1). The last page of the first volume is dated 11.2.1940. The time of the second volume's composition can be divined from repeated parenthetical remarks, such as 2: 9: "and to this day, at the age of 58, I ..." (that is, in 1948-N.P.), or 2: 44: "an impression to which I dare confess only after 29 years" (that is, in 1947). The volume was obviously composed in 1947-48. The reader learns about these two years in Freidenberg's life from the Correspondence and from later entries, forming the content of volumes 13-15 of The Race of Life.

Thus, there is an eight-year span between the end of the first and the beginning of the second phase, describing Ol'ga Freidenberg's entry into the university. During these years she would endure the ordeals of war

${ }^{16}$ Gasparov, “Poetika Pasternaka,” 370-75. 
and the blockade; in 1944 she would lose her beloved mother; in 1945 she would learn of Leonid Osipovich Pasternak's death; she would lose friends and colleagues dear to her heart; and in the university she would witness the moral and professional degradation of the scholarly work she had begun. In 1948, in connection with "certain well-known events in the field of literary criticism," she would pass through "a number of shocks" and would try unsuccessfully to be released from the department due to illness. During the anti-cosmopolitan campaign, fearing to bring misfortune upon Boris Pasternak, she would interrupt her correspondence with him for a year and a half (from March 1947 to September 1948): "If I don't write, it is only (but this 'only' covers a multitude of things) because the epistolary genre has gone out of fashion. It is no longer in keeping with the times and doesn't fit into one's frame of mind, let alone one's emotions."17

During this difficult time Freidenberg, while compiling the second volume, reread the first volume of her memoirs and thus, as it were, went through "a race of The Race" with pain and "sobbing" (her expression), becoming convinced of the collapse of "cosmism" and "monism"-the main principles of her life. And during these same years, in one letter after another, Pasternak repeated:

I am madly, unutterably happy in my free, open, all-embracing acceptance of life, an acceptance I ought to have known-or at least I would have been better off for knowing-at the age of eighteen or twenty, but then I was constrained, then I had not yet grown up to basic things and did not know, as I have since learned to know, how wonderful is the language of life, the language of earth, the language of heaven. ${ }^{18}$

\section{B. Freidenberg and Pasternak Reflect on a Common Historical and Philosophical Background}

A classical scholar who wrote much about the eschatologies and utopias of antiquity, finding in the grammatical forms of ancient Greek (future in the past) philosophical formulae for the expression of eternity and for the idea of immortality in epics (Hesiod's Works and Days, Genesis in

\footnotetext{
17 Ol'ga Freidenberg to Boris Pasternak, 28 March 1947, Mossman, Correspondence, 270; see also her letter of 9 October 1948, ibid., 279-80.

18 Boris Pasternak to Ol'ga Freidenberg, 29 June 1948, Mossman, Correspondence, 277. Pasternak's expression "eshche ne sravnialsia v chem-to glavnom so vsem na svete" can also be translated as "did not equate myself to everything on earth in terms of something that was basic." On this same feeling of his own personal "undeserved" happiness and harmonic merging with life, see Mossman, Correspondence, 248, 263, 274-75.
} 
the Bible), Freidenberg now reduced the experience of the years she had lived through to the formula of nonfulfillment.

Attempting to swim against the current of the "river of time," Freidenberg tried to publish at least some small "extracts" (as if she were a medieval pharmacist) from her new monograph, Sappho. Toward the Origin of Greek Lyrics. ${ }^{19}$ At academic meetings of her department in January and April 1947, she read two of her fragments on Sappho; on 31 January, she inserted the abstract of her first presentation into a letter to Pasternak, added to it a general outline of the paper, and, most importantly, told how, in order to prove her main thought about the inimitable uniqueness of the ancient Greek metaphor, she had taken Pasternak's artist from On Early Trains (Na rannikh poezdakh) "as a pole."20

Pasternak responded two weeks later with an enthusiastic letter:

The three pages of your outline represent a matter of the greatest profundity and presage a revolution, rather like the Communist Manifesto or the Epistles. How characteristic it is of you to see things in their true, pristine freshness!... All this is strikingly true and unusually congenial to my way of thinking and to what I am writing now in the novel (where there is a certain reflective, unfrocked priest from the literary circle of the symbolists, along with his notes about the Gospels, about the image, about immortality). You couldn't have known about this. Some of the expressions are directly from there. ${ }^{21}$

A year and a half later, Pasternak sent the preparatory draft of the first volume of Boys and Girls (Mal'chiki $i$ devochki, later to be Doctor Zhivago) to Leningrad via an acquaintance, and now Freidenberg hurried and found it difficult to express her feelings:

What is my opinion of life? This is life, at its broadest and greatest. Your book is beyond judgment. What you have said about history as a second universe applies to your book. It conveys something enormous. Its novelty is particularly new (fortuitous tautology), and it is not a matter of genre or plot, and certainly not of character... It is a special version of the Book of Genesis. Your genius shows its full depth here. I held my breath as I read

\footnotetext{
19 The metaphor "river of time" (reka vremen) from Gavriil Derzhavin's last, unfinished poem "A Slate Ode" (Grifel'naia oda), is connected with the idea of eschatological destiny in Pindar's Nemea 4. Freidenberg worked on the monograph Sapfo ( $k$ proiskhozhdeniiu grecheskoi liriki) in 1946-47, but the study remained unfinished. For more on this subject, see pp. 198-205 of this monograph.

20 Mossman, Correspondence, 265-67.

21 Ibid., 267-68.
} 
the philosophical parts, afraid they would reveal the final mystery, which one bears within oneself and always hopes to reveal or to have revealed in art or science-yet dreads the revelation of, since the mystery should always remain a mystery.

You cannot imagine the sort of reader I am: I read at once the book and you and our common blood, and so my opinion therefore is not that of the ordinary reader...

The realism of the genre and of the language does not interest me. That is not what I prize. The novel has a grandeur of an entirely new sort, more overwhelming in scope than in idea. ${ }^{22}$

These fragments of a dialogue in letters have attracted the attention of Pasternak's biographers, but no comparison has been made between the nature of these exchanges and the content of Freidenberg's scholarly works along with the meta-theoretical layer that informs them (that is, the authorial commentary on her own works); no attempts have been made to find in the text of Doctor Zhivago traces of cultural ideas, which, in forming the general intellectual and emotional background of a period, were experienced by Pasternak and by Freidenberg differently, but were interpreted in similar poetic and aesthetic categories.

Pasternak knew more than just the "three pages" of Freidenberg's summary. He was quite aware of her main scholarly achievements and knew about them not only from letters but also from offprints sent to him by Freidenberg. After reading the articles "The Plot Semantics of the Odyssey" ("Siuzhetnaia semantika 'Odissei") and "Three Plots or the Semantics of One" ("Tri siuzheta ili semantika odnogo"), he wrote to Freidenberg:

How marvelously you write! If only I could do as well!... The ideas you express are very close to my own. How I regret that I do not know and will never know this entire current in its fundamentals. I feel a close affinity for its basic methodology (Cassirer was a pupil of Cohen), but I have never studied the philosophy of language. It was about symbolism as a principle of every art I was thinking, however ignorantly and amateurishly, when I wrote Safe Conduct, and for that reason I so enthusiastically underscore lines of yours such as "There is no such thing as

22 Ol'ga Freidenberg to Boris Pasternak, 29 November 1948, Mossman, Correspondence, 282-83. Freidenberg notes in the manuscript a phrase corresponding to what was said in chap. 2, pt. 3 of the definitive text of the novel (see $B$. Pasternak, $S S, 3: 67$ ). It is characteristic that she takes note of Pasternak's expression that paraphrases his early poetic "philosophem" from Safe Conduct: "But because there was no second universe from which one could have lifted reality out of the first..." (see B. Pasternak, $S S, 4: 161$ ) 
actions in process, there is only their simultaneous existence on a plane," "Unity is revealed only in diversity," "Owing to the law of relationship on a plane, rather than in process...," "The image is born of reality, perceived as a counterconcept of this very reality," and so on. How well you formulate your thoughts! What words you find! $!^{23}$

In February 1929, Pasternak attended Freidenberg's long talk-her survey of Poetics of Plot and Genre, which she gave in the Communist Academy (Komakademiia). In 1936, right after the book came off press, Freidenberg sent a copy of Poetics to Moscow; as we know, Pasternak took an active emotional part in the misfortunes that befell the book and its author, helped Ol'ga Mikhailovna, and even wrote to Bukharin about her. ${ }^{24}$ Thus one can speak about Pasternak's real knowledge of Ol'ga Freidenberg's works with greater certainty than is the case in Gasparov's work. An answer to the question- "in which specific group of Pasternak's poetic ideas can one find correspondences to Freidenberg's scholarly works"-will obviously depend on the use of the overall scope of the documentary sources cited. ${ }^{25}$

23 Mossman, Correspondence, 146-47. Pasternak is citing the key propositions of the article "Tri siuzheta ili semantika odnogo," Iazyk $i$ literatura 5 (1929): 38, 43, 53,58 . These theoretical formulations of Freidenberg find a correspondence in the poetic semantics of the repeating images in Pasternak (from Safe Conduct and "Zhenia Liuvers's Childhood" to Doctor Zhivago). Examples from Childhood: "For the first time in her life she suspected there was something that phenomena kept to themselves-or if they revealed it they did so only to people who...", "She wanted to rave like the foul weather that raged about them... And even now the snow was already sweeping down in earnest. The heavens quivered, and down from them tumbled whole white kingdoms and countries. They were countless, and they were mysterious and dreadful!" (B. Pasternak, SS, 4: 36, 72). In 1946, Freidenberg sent Pasternak the offprint of "The Origin of Greek Simile." He read it with great interest and appraised the most important elements of the theory of cognition, which Freidenberg explained using the material of the epos of antiquity. About the philosophical explanation of "the role of the image-component of the likening" proposed by Freidenberg, he wrote that it was similar to his manner "in its strength and weakness, in the lively freedom with which you shift from theme to theme (Mossman, Correspondence, 262).

${ }^{24}$ Mossman, Correspondence, 157-72. For excerpts from Pasternak's letter to Bukharin which refer only to Freidenberg and her work, see ibid., 167-68. On 15 December 1936, Freidenberg wrote to Leonid Pasternak about the evening she spent in Moscow, "among two related families" (Boris and Aleksandr Pasternak-N.P.), where they celebrated with a festive dinner and wine the repeal of disfavor from her book (Pasternak Trust, Oxford).

25 Gasparov ("Poetika Pasternaka," 374-78) examines the problems of the perceptual and the conceptual cognition of the world; traces the correspondences of 
In the "notes" of Nikolai Nikolaevich, Iurii Zhivago's favorite uncle, one can easily find a precise analogy to the outtakes Pasternak appreciated so greatly in the "extracts" of Freidenberg's works. Pasternak's hero discusses the poetics of archaic cosmogonies and in what ways this antiquated genre "is wholly out of keeping with the spirit, the essence, the motivating force of contemporary art."

Pasternak: These cosmogonies were natural in the ancient world-a world settled so sparsely that nature was not yet eclipsed by man. Nature hit you in the eye so plainly and grabbed you so fiercely and so tangibly by the scruff of the neck that perhaps it really was still full of gods. These were the first pages of the chronicle of mankind, it was only just beginning.

Freidenberg (as summarized by Pasternak): Lyric poetry represents a great change in social consciousness, a stage in the cognitive process, a shift in the world outlook. The universe is inhabited for the first time by people in a social world. The myths of the gods become the biographies of poets. ${ }^{26}$

In the article "The Origin of the Greek Lyric," which Freidenberg planned to include as a chapter in her monograph on Sappho, she argued her thesis in a more philosophical vein: man in the history of culture and the "picture of the universe" created by him at various historical stages. The work proposes an analysis of the genesis of the ancient lyric. Freidenberg connected the origin of the new poetic genre with a great change in the relation between the cognized world and the cognizing human consciousness. The separation of the human from surrounding nature and the recognition of this very separation as the moment of the "birth of the lyrical author," in turn, retained in itself the faculties of that process by which one could see or hypothesize the real development that brought concepts into being.

Analyzing the separation of the cognizing subject (the poetic " $\mathrm{I}$ " of the lyrical song-maker) from the cognized object (reproduced in the verbal images of the external world), Freidenberg concluded that the lyrical author in the archaic Greek lyric "represents a form of unique subject, not yet fully separated from the object, not independent, but appearing in its function." ${ }^{27}$ In other words, the perceptual images that serve as a

the world of "unconscious infant" and "rational knowledge"; and notes correspondences between Pasternak's metaphoric poetic thinking and the scholarly understanding of metaphor in Freidenberg's works as well as in the theoretical trend to which Freidenberg was connected.

26 B. Pasternak, SS, 3: 45-46; Correspondence, 267-68.

${ }^{27}$ Freidenberg, "Proiskhozhdenie grecheskoi liriki," Voprosy literatury 11 (1973): 106-7. 
means of expression for the lyrical "I" of the song-maker and the verbalpoetic figurative fabric of ancient lyrics reconstitute the inner, morphological components of archaic mythological perceptions. These perceptions are themselves retained in their structure, according to which

the lyrical author himself is seen as the form of a god. Divinity crystallized the perception of a world already separated from man. However, a human already removed from divinity still continues in certain unconscious acts to experience himself as one of the types of divinity... The lyrical author continues, from the cognitive point of view, to be a divinity. This is its specific form, however, no longer figurative but conceptual. ${ }^{28}$

Analyses of the twofold formulas no longer/not yet; visible (the perceivable form of the object)/speculative (the form of the concept); figurative/conceptual; the translation of the concrete image-object into the image-concept; the portrayal of the subjectively individual in the forms of the objectively collective and as not yet personal (biographies of poets and of victors of athletic games and military conquerors seen through myths about gods and immortal heroes) can be found in all of Freidenberg's works-from her master's thesis of 1924, The Origin of the Greek Novel (the other title, The Greek Novel as Acts and Passions), to her last monograph, Image and Concept, which discusses the origin of the simile, metaphor, narration, as well as the genesis of the archaic mimos (performances by mimes) that later engendered both Greek tragedy and Greek comedy. ${ }^{29}$ In new cultural-semantic forms, in new "formants," transferring the new relationship of the cognized world and the cognizing human consciousness, she recognized the relics of invariable morphological elements - the constituents of the most ancient mythologies. Freidenberg interpreted the survival of archaic collective perceptions in images as resemantization, as an assimilation of an individualized, conceptual, qualitatively new content of meaning.

Whatever forms of poetic thinking Freidenberg might discuss, she always insists that the transference and transformation come about in the consciousness of either a cognizing community or an individual who perceives the world in the forms of the collective consciousness. The transformation is experienced, seen, and comprehended by analogy with the transformations occurring in nature and the cosmos. In reaccented form, the components of the cosmogonic worldview become the elements of an individual-poetic seeing of the world. The morphology of archaic cosmogonies enables the construction of new metaphors, representing a

28 Ibid., 107.

${ }^{29}$ O. Freidenberg, "Proiskhozhdenie grecheskogo romana," unpublished; see Sorokina, "Kratkoe opisanie," 776. 
poetic image of a new world. The constituent morphemes of archaic mythologies are assimilated as components of new plots and genres-of genres, however, that no longer belong to cosmogonic religious consciousness but that constitute forms of the preliterary folklore of the early Christian worldview. In one group the selfsame mythological substratum enters into the formation of apocryphal gospels, vitae, and acts, and in another group it makes up the key elements in the plots of ancient Greek love novels.

Familiar with the main ideas of Freidenberg's master's thesis, The Origin of the Greek Novel, ${ }^{30}$ Pasternak recognized in her Sappho fragments of the 1940s ideas already known to him from her earlier works. However, the elective affinities between Pasternak and Freidenberg are to be found not in the common themes contemplated by them both-after all, starting with Nietzsche, all the symbolists, as well as the majority of mythologists from the end of the nineteenth and the first third of the twentieth century wrote about various interpretations given by early Christianity to the myths of the suffering and resurrecting pagan gods. Rather, the elective affinities are to be seen in their ability to discover, independently of one another, congenial genres of poeticphilosophical utterances, to interpret in comparable categories the visible picture of the universe, and, once again independently of one another, to find unique formulas for the depiction of that which they had comprehended.

These elective affinities, of course, developed all the while in accordance with what was for the two of them a common cultural, philosophical, and aesthetic experience. To the extent that their correspondence was a dialogue, Pasternak invariably referred in his letters to his overall knowledge of the subject of her scholarly inquiries. Neither agreed with the theory of syncretism and its interpretation of cultural evolution. For both, the myths of death and resurrection of the pagan gods of vegetation and the seasonal transformation of nature were only figuratively but not conceptually comparable to the idea of the Resurrection in Christianity. In her master's thesis, while analyzing "The Acts of Thecla," Freidenberg demonstrated that the cultural semantics of the name of the heroine, Thecla (decla, "palm" in Hebrew), reveals the cultural survival of the archaic myths of the rising gods of vegetation. However, she also asserts that the conceptual aspect of the acts of Thecla, the Christian martyr, is not the result of a mere quantitative accumulation of disparate archaic experiences of polytheistic cultures. Correspondingly, in Pasternak the world of contemporary man cannot be interpreted in the categories of ancient cosmogonies. It was not neces-

${ }^{30}$ In 1924, Pasternak tried to help Freidenberg in the publication of this work. Mossman, Correspondence, 74-89. 
sary for Pasternak to refer to Freidenberg's articles on the semantics of the name in order for him to present his system of poetic allegories in the poem "Holy Week," to circumvent and refute the ideas of syncretism. In him, nature awakens "on hearing spring put forth its rumor" (zaslyshav shum vesennii), but the miracle of the Resurrection is infinitely higher than the efforts of nature: "Two birches / Guarding the portals have to step aside" (I dve berezy u vorot / Dolzhny postoronit'sia) to make way for "the procession with the shroud of Christ coming toward them" ( $i$ vdrug navstrechu Krestnyi khod vykhodit c plashchanitsei). ${ }^{31}$

Coincidentally, Freidenberg received a manuscript of Doctor Zhivago from Moscow at the very time that she was rereading the first volume of The Race in conjuction with her preparations for the second installment of the same work. In reading Pasternak's novel, she indeed was reading the book, and life, and herself, thus coming to realize how direct biographical experience was transmitted by both of them to a deeper existential level. She wrote to Pasternak: "You cannot imagine the sort of reader I am: I read at once the book and you and our common blood, and so my opinion is not that of the ordinary reader. This book must be possessed rather than read, as a man does not read a woman but possesses her. For that reason, slipshod reading makes no sense at all." ${ }^{32}$ Combining in the text of The Race biographical pages with her own metatextual commentary to the depicted past, Freidenberg (speaking in the language of her scholarly works) demonstrated how "in the course of history, one and the same thing takes on different forms, being subjected to different interpretations and being cast in different language forms. Hence what we have before us is a bivalent phenomenon: internal identity and external diversity." ${ }^{33}$ This ability to recognize the internal identity behind the external diversity of language forms and to perceive embryos of future diversity in a single prototype made her reading of Doctor Zhivago so penetrating and perceptive.

On the family and mundane daily levels, Freidenberg's memoirs present the distinctiveness of the setting that Pasternak described during work on his novel as "the proscenium in the performance, the place of greatest concentration in the whole drama, essentially a homogeneous

\footnotetext{
31 B. Pasternak, SS, 3: 513.

32 Mossman, Correspondence, 283.

33 O. M. Freidenberg, Poetika siuzheta $i$ zhanra. Period antichnoi literatury (Leningrad: GIZ, 1936), 10. The first edition of this book has been long become a rarity, and recently N. V. Braginskaia published a new annotated edition: $O$. $M$. Freidenberg, Poetika siuzheta i zhanra (Moscow: Labirint, 1997; hereafter cited as Poetika siuzheta). In this edition, the reference is to 13-14.
} 
one." ${ }^{34}$ In the first paragraph of The Race, volume 1, we find: "From the very earliest days of my childhood, as soon as consciousness awakened in me, I felt myself to be on the proscenium, undoubtedly having some invisible background" (1: 1). Early childhood experience was soon enriched by a new discovery: "It consisted of the appearance of yet another world, the second to come into being" - the world of art (1: 1-2).

A comparison of The Race with Doctor Zhivago helps us discern in the verbal fabric of this latter work stylistic layers that bewildered old friends (those who were the first to hear the reading of the novel) as well as distant, refined critics-writers (Nabokov's reaction), as well as readers who were spiritually close to Pasternak but who grew up in a different environment. ${ }^{35}$ They did not understand why Pasternak felt the need to pile up episodes one on top of another, making the plot improbable, to exclude descriptions of psychological persuasiveness, and in a lyrical-heroic epic to fall into the starry-eyed tone of Lidiia Charskaia. Freidenberg, after reading the manuscript, enthusiastically accepted all these incongruities:

The realism of the genre and of the language does not interest me. That is not what I prize. The novel has a grandeur of an entirely new sort, more overwhelming in scope than in idea... your passionate preoccupation with the idea of immortality that you are constructing with your life's blood ... much that is dear and close to me, that is wholly my own, as well as much that is of our family in its great and small demands on life, ranging from abstract categories to solutions of personal problems. In saying "the dear" and "of our family," I have in mind "the great" transposed to individual instances (and not concrete trifles per se). ${ }^{36}$

Both the individual chapters of The Race and the texts of many scholarly articles by Freidenberg are replete with such "transpositions" when individual instances speak in a private family language "about history

\footnotetext{
34 Boris Pasternak to Ol'ga Freidenberg, 30 November 1948, Mossman, Correspondence, 274.

35 For the bewilderment of friends who were invited to Pasternak's reading of the novel, and the restrained disapproval of the first readers of Doctor Zhivago, see E. Pasternak, Boris Pasternak, 588-96; for Nabokov's reaction, see his letter to George Weidenfeld, 12 January 1958, in Vladimir Nabokov, Selected Letters (San Diego, New York, and London: Harcourt Brace Jovanovich, 1989), 273-74, and Brian Boyd, Vladimir Nabokov: The American Years (Princeton: Princeton University Press, 1991), 370-81.

${ }^{36}$ Mossman, Correspondence, 283.
} 
as a second universe." ${ }^{37}$ The description of school-time and vacation amusements in Freidenberg's memoirs and in Pasternak's novel are comparable to the jolly weekdays of Princess Dzhavakha in Lidia Charskaia and other lady-writers of the early twentieth century; the awakening of the feminine nature in Lara Gishar is similar to certain passages on the same subject in Olia Freidenberg's autobiography-but she had not, after all, shown Boria her girlhood diaries!

Outside the bounds of the narrowly familial circle, an analogue to the text of Pasternak's novel in The Race seems to be the stories of Tonia, a girl of the same age from a poor neighbor family, and even more so the

scenes from our back yard (dvorovye kartiny). They entered as impressions but stayed as component parts of [my] character. The little girl who was tormented by her stepmother with exhausting work (the horror of such torment). The huge girl with breasts like two large melons; she would easily and quickly wash the wooden staircase and then would go out with a soldier (an attraction to what was large and abundant, to the ease of heavy labor). The janitor was exceptionally fat, with a handsome, combed out beard, not very old; it was not a secret that a thin, scraggy old woman lived with him; her husband, a bent-over and emaciated old man, worked as the yardkeeper across the way." (1: 11)

The formula by which Freidenberg explains the psychological assimilation of the pictures of the outside world enables one to understand and accept the specific features of Pasternak's novel that so irritated even his most devoted readers such as Ariadna Efron: "I cannot but get angry when I recall, find, and copy this disgusting account: 'she bathed and swam, boated, took part in night-time picnics beyond the river, lit fireworks with everyone else, and danced.' And why should you write like this? And about Larisa!" ${ }^{38}$ But in Pasternak this is how the subjects of the external plane are rendered, those that have not become an

${ }^{37}$ Particularly characteristic in this regard is Freidenberg's work "On Stable Plots and Wandering Theoreticians," which had the provocative subtitle "From a Business Notebook" ("O nepodvizhnykh siuzhetakh i brodiachikh teoretikakh, iz sluzhebnogo dnevnika") and was presented at the meeting of the "Sector for Studies in the Comparative History of Languages and Literatures" in the State Institute of Speech Culture (Institut rechevoi kul'tury; IRK) on 19 February 1931. For the publication of the work, with an introductory article and commentary by Nina Braginskaia, see the collection Odissei. Chelovek $v$ istorii (Moscow: Nauka, 1995), 244-71, 272-97.

38 A. Efron, Pis'ma iz ssylki, 1948-1957 (Paris: YMCA-Press, 1982), 29. For the lines cited, see B. Pasternak, SS, 3: 77. 
internal impression and have not entered into the personalities of his heroes. And here is an excerpt from the first volume of Freidenberg's memoirs:

I became the ringleader of my class, broken down into castes. I performed brilliantly at soirees. Everything that was most original was assigned to me; people started to single me out and admire me... And youth kept unfolding... I was a madcap who, with a gang of hungry high-schoolers, dazed peaceful citizens, our victims." (1: 40-41)

Joined by "elective affinities," Pasternak and Freidenberg were alike in understanding how time performs its "race" through man's destiny, bringing to "the preordained perfection" the great and the most important, as well as the intimate and the familial. As a memoirist, Freidenberg remembers only those impressions of the external plane that are in harmony with the constants of her personality; and as a scholar, she insists that one and the same thing, reemerging, creates diversity and becomes a component of differences absorbed by the history of culture. Pasternak endows his Iurii Zhivago with a similar ability to remember selectively. The forms of experiencing and expressing ideas in Doctor Zhivago and The Race are often so close that if not for the grammatical categories of gender indicating different narrators, the notations of the memoirist could be taken for the monologues of the literary hero and vice versa. About the February Revolution, it is said in The Race:

Everyone prepared for the revolution, from the first to the last person. If I had not lived in that epoch, I could not imagine what the singlemindedness of many millions of people, of all events, of everything that takes place means. The huge empire, the steppe, forests, and mountains all headed for revolution.

Революция подготовлялась всенародно, от первого до последнего человека. Если 6 я не жила в эту эпоху, я не могла бы себе представить, что значит единодушие многомиллионного народа, всех событий, всего происходящего. Огромное царство, степи, леса и горы, все устремлялось к перевороту. (1: 178)

One can easily take these lines for a first draft, later reworked into the final text of Doctor Zhivago:

Just think what is going on around us! And that you and I should be living at such a time... Last night I was watching the meeting in the square. An extraordinary sight! Mother Russia is on the move, she can't stand still, she's restless and she can't find 
rest, she's talking and she can't stop. And it isn't as if only people were talking. Stars and trees meet and converse, flowers talk philosophy at night, stone houses hold meetings... The revolution broke out willy-nilly, like a sigh suppressed too long. Everyone was revived, reborn, everything was transformed, overturned.

Вы подумайте, какое сейчас время! И мы с вами живем в эти дни!... Вчера я ночной митинг наблюдал. Поразительное зрелище. Сдвинулась Русь-матушка, не стоится ей на месте, ходит не находится, говорит не наговорится. И не то чтоб говорили одни только люди. Сошлись и собеседуют звезды и деревья, философствуют ночные цветы и митингуют каменные здания... Революция вырвалась против воли, как слишком долго задержанный вздох. Каждый ожил, переродился, у всех превращения, перевороты. ${ }^{39}$

Both in The Race and in the novel the word "revolution" by its very morphological composition indicates a circular motion, "over-turn," in the sense in which Copernicus entitled his work: "the revolutions of the heavenly orbs." An interest in the dynamics of cyclical, internally static repetitions, cataclysms, and catastrophes (the Greek katastrophe, "overturn"-kata, down, and strophein, turn) accompanied Freidenberg her whole life. ${ }^{40}$ In late 1928 , she was commissioned to give a talk to the Society of Marxists on the subject "Revolution in the Ancient World," which she turned into a report on the subject of "The Teaching of the Greeks about Upheaval" (katastrophe, perevorot). In the theses for the report she wrote:

The direct sources of Greek teaching about social upheaval are individual parts of Plato's The Politics and Aristotle. They can be understood only in connection with the main course of development of Greek theoretical thought... One must look at the semantics of thought that was to be reworked by the Greeks. The bearers of such a [semantic-N.P.] legacy are Greek cosmology, Greek ethics, and the compositional core of certain Greek literary genres. Cosmology explains the creation of the world through struggle and upheaval. Religious-ethical thought introduces the concept of "moral regeneration," transferring the struggle and the crisis inside the individual person. In tragedy,

\footnotetext{
${ }^{39}$ B. Pasternak, SS, 3: 145.
}

${ }^{40}$ Freidenberg was very familiar with the theories of cataclysms according to Spengler and found in his morphology of culture a common pattern of cycles of development that corresponded to her own anti-evolutionary interpretations. 
comedy, and the novel, there remains the parallelism of an external major turning point and an internal regeneration, which is thought of now concretely, now symbolically... The Greek idea of upheaval is close to our concepts of mutation, revolution, catastrophe, a sharp change-over to its opposite. This process is characteristic only of the material world; with it is closely tied the concept of diversity, differentiation, realization in time. (4: 62-64)

Pasternak was aware neither of these theses of Freidenberg's nor of their further development, which provided the content of her late unpublished monograph The Semantics of the Composition of Hesiod's "Works and Days." But considering that all the preliminary drafts, as well as the definitive text of Doctor Zhivago, have now come to light, if we were to take up an interpretation of the most "a-logical" of its episodes-such as the sudden transformation of the meek and shy Pavel Antipov into the "armor-clad" commissar Strel'nikov-the understanding of this transformation of "Paul into Saul" would appear explicable from Freidenberg's point of view. The essence of the inner upheaval that took place with Pasternak's hero may be understood as a "transference of the battle inside the individual person," as catastrophic mutations gripping the universe - the heavenly bodies, the earth, the floral world, and the material and psychological world of the individual person. ${ }^{41}$

In the second book of Doctor Zhivago (which in 1948 had not yet been written), we find an even more intriguing instance where elective affinities and the commonality of cultural-historical experience take the form of, as it were, direct quotations from Freidenberg's main theoretical statements. This includes Sima Tuntseva's arguments concerning the history of Christian mythology, a kind of "inserted philosophem" (vstavnaia filosofema, by analogy to inserted novel, vstavnaia novella). In the "introductory part" of the lecture, Sima proposes to replace the concepts of "culture, epochs," in view of their ambiguousness, with the figurative expression "God and work," characterizing the development of the human spirit: "Such a work was Egypt. Greece was another. The Scriptural Teaching of the prophets (bibleiskoe bogopoznanie prorokov) was a third. The last in time, not yet superseded by anything else and

41 A similar interpretation of mutation and transformation can be found in the second book of Pasternak's novel, in the "notes" of Iurii Zhivago: "He reflected again that he conceived of history, of what is called the course of history, not in the accepted way but by analogy with the floral world ... upheavals last for weeks, at the most for years, and then for decades, for centuries, the spirit of narrow-mindedness that led to the upheaval is worshipped like a divinity." B. Pasternak, SS, 3: 448. 
still being accomplished by all who are inspired, is Christianity." 42 This part of Sima's "lecture" corresponds to the ideas that Freidenberg developed in her master's and doctoral dissertations. Sima's examples, in which "Mary's motherhood is compared to the crossing of the Red Sea by the Jews," emphasizing with equal force "the oldness of the old and the newness of the new" (that is, pointing directly at mutations and transformations), have their correspondence in Poetics of Plot and Genre, as well as in philosophical anthropology and in the history of mythological representations of antiquity on which Freidenberg's writings were based. Sima's lecture on Mary Magdalene and the episode from the Holy Scriptures, which will later be transposed into Iurii Zhivago's poems, also have corresponding counterparts in the Poetics of Plot and Genre. ${ }^{43}$

Earlier still, in her master's thesis, while explaining the meaning of the love element in ancient myth, in Christian apocrypha, and in the ancient Greek novel, Freidenberg wrote: "But is this love, erotics, marriage?... This is a chaste, sacral perception of the forces of productivity, elevated in its essence, majestic in its merging with the life of all of nature, just as pure as 'In Thine Name.' There is nothing related to 'erotic love' in this religious idea." And in the "Conclusion" of the second book of Doctor Zhivago, in the scene depicting Lara's lament over Iurii's body, we read:

They loved each other, not driven by necessity, by the "blaze of passion" often falsely ascribed to love. They loved each other because everything around them willed it, the trees and the clouds and the sky over their heads and the earth under their feet. Perhaps their surrounding world, the strangers they met in the street, the wide expanses they saw on their walks, the rooms in which they lived or met, took more delight in their love than they themselves did. ${ }^{44}$

42 B. Pasternak, $S S$, 3: 405.

${ }^{43}$ Cf. B. Pasternak, SS, 3: 406, and Freidenberg, Poetika siuzheta, 79-81; 198201 , as well as 314 , ff $199,204,208$ (references to the works of I. FrankKamenetskii, which treat the use of tropes produced by the semantics of water in archaic mythologies and biblical folklore).

${ }^{44}$ Freidenberg, "Proiskhozhdenie grecheskogo romana," 98; B. Pasternak, SS, 3: 494. Freidenberg's work includes the translation she did of the apocrypha. Commenting on the language of the original, she gave an explanation of the word "hierodule," which, according to her interpretation, indicated not erotic debauchery, but chastity and purity. See further, p. ${ }^{* * *}$. 
Freidenberg wrote her thesis about Thecla, a Disciple of the Apostle Paul, as if in anticipation of Pasternak, in whose drafts to Doctor Zhivago we find the following passage:

Our time understood anew that side of the Gospels ... which artists long since had best felt and expressed. It was strong in the Apostles and then disappeared in the Church Fathers, in the church, morality, and politics. Francis of Assisi made us remember it passionately and keenly.... It is the idea that relations among mortals are immortal and that life is symbolic because it is significant.

And Freidenberg wanted to entitle her work on the origin of the Greek novel "Ver Corporis" ("spring of the body," an expression of Minucius Felix, a pagan author who converted to Christianity at the end of the second century A.D.). ${ }^{45}$ For everyone who remembers the text of Doctor Zhivago, these words can be understood also as a metaphor of the hero's life-a healer and a poet whose name in its very semantics reveals the universal code of immortality. ${ }^{46}$

Endowed with the gift of "creative intuition," Freidenberg "read herself" and her life in Pasternak's poems and in his prose. The first and second volumes of The Race abound in self-reflection, the meditative forms of which are cast by Pasternak's lyrics: "Thus began my new birth from a seed that had gone into the earth. I was being resurrected in a new form, in complete severance with everything that had constituted up to then my 'I.' Once again I was passing through an exit" (2: 105). There is nothing simpler than to entitle the landmarks of her life's path with quotations from the title of Pasternak's poetic cycles- "Twin in the Stormclouds," "Second Birth," "My Sister Life," "On Early Trains." Perhaps this would be too simplistic for an outline of the biography of Ol'ga Mikhailovna Freidenberg-an original scholar, a talented memoirist, and a colorful creative personality. Yet the very naiveness of the device enables one to envision clearly the most desirable reader for the literature of the new type (such as Pasternak's prose) and helps to understand the interpersonal links known as "elective affinities."

\footnotetext{
45 B. Pasternak, SS, 3: 575 (quotation from the draft of the novel); Freidenberg, "Proiskhozhdenie grecheskogo romana," 29. For Minucius Felix, see The Cambridge Ancient History, ed. S. A. Cook et al. (Cambridge: Cambridge University Press, 1965), 12: 595.

46 On Pasternak's "passionate preoccupation with the idea of immortality" and his "consciousness of the futility of one's best intentions and achievements," see Freidenberg's letter to Pasternak of 29 November 1948 and his reply of 30 November 1948. Mossman, Correspondence, 283-84.
} 


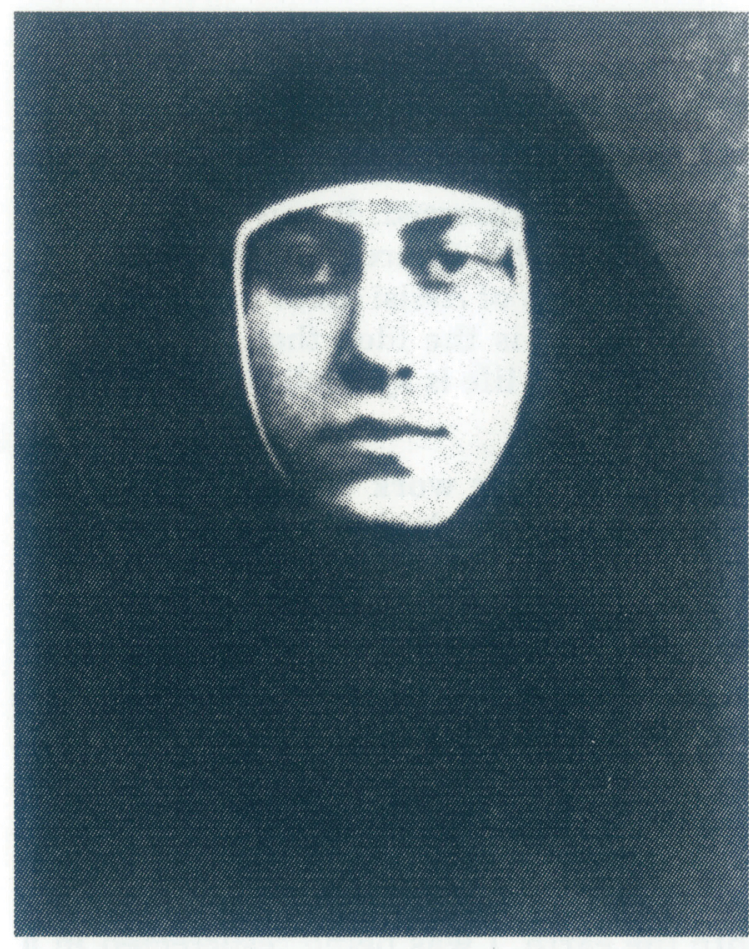

Freidenberg as a

volunteer nurse

Pasternak, early 1920s

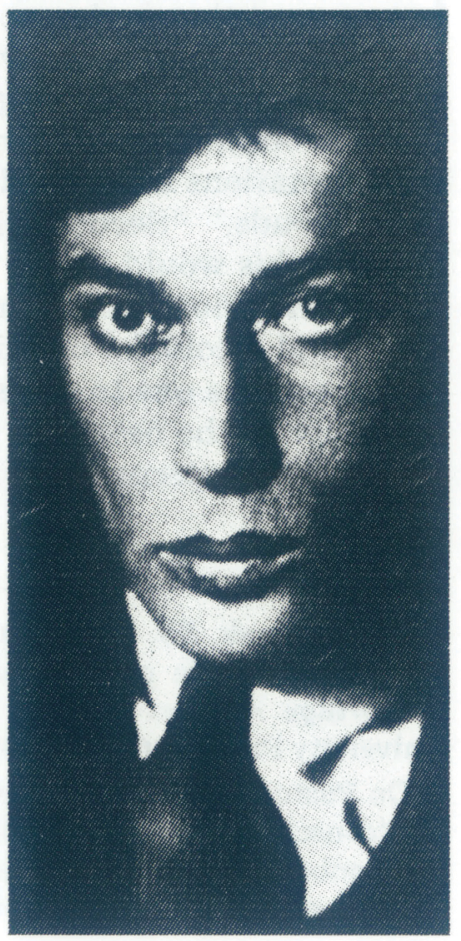


Part 2

\section{The Years of Apprenticeship}

Значит-в «море волнуется»? В повесть, Завивающуюся жгутом,

Где вступают в черед, не готовясь?

Значит-в жизнь? Значит-в повесть о том, Как нечаян конец?

Борис Пастернак, «Зима» 
Chapter 2

\section{At the Department of Classical Studies: A Female University Student of a New Type}

\section{A. One of the First Women Enrolled at Petersburg University}

$\mathbf{F}$ reidenberg entered Petersburg University a half year after the February revolution, only two months prior to the Bolshevik coup. February Revolution with the world's ultimate upheaval, which was equated with the common cause of the nation "from the first to the last person": "I knew soldiers safe-guarding Tsar Nicholas, his body-guards; I had acquaintances among the Emperor's guard officers in Tsarskoe Selo. They, and the Great Dukes, Nicholas's relatives, and every philistine-everybody wanted revolution" (1: 178).

The Bolshevik period, in contrast,

was the time of the greatest daily hardships. In the lofty language of history it has been named "the Revolution," and youth used to believe that it would be Karl Moor, Robespierre, the great Romantics. Yet in reality it is just Zinov'ev and Trotskii, an arrogant satiety which mortified millions of people by starvation and deprivation. This revolution is a horrible thing! It substitutes one form of coercion for another, and the process of pulling down one class of exploiters and installing another is horrifying. Russia has deteriorated like a rotten rag. They called this the dictatorship of the proletariat. The reign of Trotskiis and Zinov'evs has been a living grave. Starvation, meetings from dawn to dusk on every sidewalk and road, the black market, smashed street cars for free-everything was for free: apartments, medicine, human lives. (2: 68-69)

During her academic apprenticeship, Freidenberg experienced the dual impact of the liberating February Revolution and the increasingly oppressive pressure of Bolshevik dictatorship. Describing her first year at the university, Freidenberg stated: "The freedom of university teaching marvelously shaped my outlook. This was the Cronian age of liberty, 
as we (all pressed together by the political police) look at it from today. The professors all differed one from another, each with his own intellectual outlook. They announced any courses they wanted to teach." In her first year, still unsure about her future in the Humanities, Freidenberg attended the classes of the popular philosophers Aleksandr Vvedenskii, Nikolai Losskii, and Ivan Lapshin (the notes taken at his lectures are preserved in her archive).

The revolution treated Lapshin and Losskii cruelly (and not only these philosopher-idealists). They were deported and deprived of their motherland.... People whose lives had been built into their old family apartments or molded by bachelors' habits-they experienced the loss of their motherland and surroundings as a great tragedy. If only they could have known that this was the greatest mercy of the revolution, that the time of Stalinism, when the beast would not let victims fall from its clutches, and would constrict them with a lasting and ferocious smothering, was yet to come! $(2: 2,8)$

Of the fourteen professors whose lectures Freidenberg attended during 1918-20, six died from epidemic diseases and starvation, and five were deported or forced to emigrate by the end of $1922 .{ }^{1}$

Despite the oppression and hardships imposed by the regime, Freidenberg experienced her university days as "a sheer intoxication with happiness" (2: 39). Her teachers-the historian of the Russian schism Aleksandr Kornil'evich Borozdin and the Classicist Sergei Aleksandrovich Zhebelev, described this same period as the "wicked years" (likholet'e). ${ }^{2}$

Freidenberg was one of the first female students enrolled at Petersburg University, and she recognized the difference between her own emotional and evaluative attitudes toward the post-revolutionary academic system and those of her older professors. ${ }^{3}$ Upon graduating

${ }^{1}$ Freidenberg's list includes Academicians A. A. Shakhmatov (died 1920); I. Shliapkin (died 1918); B. Turaev (died 1920); the professor of Spanish literature D. Petrov (died 1921); and the historian of Russian literature Aleksandr Kornil'evich Borozdin (died 1918.) She also mentions the renowned Classicist Faddei Zelinskii [Tadeusz Zielinski], who left Russia for Poland shortly before his colleagues, the university philosophers, were arrested and forced into exile.

2 S. A. Zhebelev, "Iakov Ivanovich Smirnov," Seminarium Kondakovianum 2 (1928): 1 .

${ }^{3}$ In tsarist Russia, women were not admitted into the universities; in 1878 the Ministry of Education had approved the establishment of the Courses for Higher Education for Women (Bestuzhevskie vysshie zhenskie kursy, St. Petersburg), whose certified alumnae were allowed as educators in private and governmental gymnasiums for women. 
from the gymnasium, Freidenberg had no knowledge of Greek and she had learned Latin from her friend, Motia Lifshits, who was not a professional teacher. Freidenberg was certain, however, that her zealous work and talent for learning would enable her to bridge such lacunae in her previous education. Her teachers, on the other hand, treated her largely as a "case" symptomatic of the post-revolutionary anarchy which had destroyed all continuity in the educational system. Even after Zhebelev admitted Freidenberg into his Greek seminar and assigned her the task of preparing a commentary to the apocryphal "Acts of Paul and Thecla" (texts he himself used as a source for the study of the Pauline epistles), ${ }^{4}$ he demonstrated no desire to work with her and offered little mentorship in resolving various philological difficulties.

\section{B. Studying "The Acts of Paul and Thecla" under Zhebelev's Direction}

Freidenberg began working with the apocrypha in 1919, when, suffering from tuberculosis and exhausted by malnutrition, she took a leave of absence from the university.

Zhebelev's book with the Greek text remained in my possession, and from having nothing else to do, I delved into this text. It captivated me. How else could it be! The Acts began with Thecla hearkening, all entranced, to her teacher, Paul. The Apocrypha spoke to me. I sensed its loving, pagan aroma, its artistry. Borozdin, Zhebelev, Tolstoi, Bush. My teachers, the entire state of my mind and heart. All these things together brought me to Thecla and placed [me] by her window.

Жебелевская книга с греческим текстом так и застряла у меня. Я, от нечего делать, вчитывалась в этот текст. Он пленял меня. Еще бы! Деяния начинались с того, как Фекла завороженно внемлет своему учителю, Павлу. Апокриф говорил мне. Я ощущала его любовный, языческий аромат, его художественность. Бороздин, Жебелев, Толстой, Буш. Мои учителя, мой весь маршрут ума и сердца. Все привело меня к Фекле и поставило у ее окна. (2: 83-84)

The content of the apocrypha had a strong psychological and biographical impact on Freidenberg. As The Race of Life makes clear, in Thecla's eager response to Paul's teachings and the apostle's hesitancy to accept a woman as a disciple, Freidenberg found an analogue to her own strained relations with her university teachers. As she eventually came to believe, the main plot-line of the apocrypha anticipated the entire story of her own life during the 1920-1930s.

${ }^{4}$ Acta apostolorum apocrypha, ed. Constantinum Tischendorf et al. (Leipzig, 1891). 
In 1920-21, recovered from her exhaustion and still attending Zhebelev's seminar, Freidenberg undertook the chronological attribution, translation, and preliminary interpretation of the apocrypha. The main textual difficulty she sought to resolve consisted of the fact that sainthood did not yet exist as a theological concept in early Christianity when the apocrypha on Thecla and Paul was created. How then did the attribute "saint" enter into the textual fabric of the apocrypha? Although the question she raised was important for the interpretation of the entire text and Zhebelev recognized its significance, he offered Freidenberg little advice or encouragement, leaving her to work on her own.

One of Freidenberg's early drafts was entitled with a quotation from the apocrypha: "One Thecla, a Virgin" (parthenos in Greek). In the paper Freidenberg offered her commentary on the notions of virginity, chastity, purity, and by conjecture-on holiness and sanctity. Zhebelev's reaction to the study was entirely indicative of his attitude towards her scholarly methods:

"How do you yourself view this paper? This is just a prospectus, not a report," Zhebelev said.

"I view it as a hurdle I must overcome in order to approach real knowledge," I said.

Then, with an even more rigid face, Zhebelev said, "Well, when you stop jumping over hurdles, I will be willing to discuss your paper" [vot kogda Vy perestanete prygat' cherez prepiatstviia, ia budu govorit's Vami]. (2: 112)

A few weeks later Freidenberg completed a well-argued fragment in which she demonstrated that, as a literary genre, the apocryphal acts of Thecla and Paul were closely related to the so-called "Greek erotic novels." Zhebelev was excited when she acquainted him with this assertion, sensing in it "the breath of true scholarship. Oh God, how happy he was!" (2: 126). From that day on, Zhebelev did all he could to help her bring her preliminary observations to completion. In 1922 he expressed his indebtedness to her in a lengthy footnote to his Apostle Paul and His Epistles: "O. M. Freidenberg, who has been studying The Acts of Paul and Thecla under my direction for a long time and with remarkable success, has come (in my mind) to the irrefutable conclusion that, as a literary genre, The Acts are closely connected with those works of Greek literature that are traditionally referred to as 'the novel' (perhaps in the conventional term). I will not relate further details of $O$. M. Freidenberg's work, in the hope that her study will soon be published."5 Laudatory as it was, the acknowledgment was couched in conditional

5 S. A. Zhebelev, Apostol Pavel $i$ ego poslaniia. Obshchii ocherk (Petrograd: Ogni, 1922), 51; on the similarities of the genres, see also 50-53. 
clauses and parentheses, distancing Freidenberg's resolute conclusions from Zhebelev's own textual divinations. The footnote's implicit distinction between his and Freidenberg's views resulted largely from the different general frameworks which the teacher and his student each assumed for their inquiries.

Unlike Freidenberg who focused her entire study on the apocryphal Acts of Paul and Thecla, Zhebelev used this text as auxiliary material, representing no more than a small part of the oral tradition of the early Christian era. He relied on a wider body of scriptural sources, using both the canonical and the apocryphal Acts of the Apostles (specifically, manuscripts discovered in the late nineteenth century by Karl Schmidt, Tischendorf, Lipsius, and Bonnet, as well as manuscripts from the corpus of Ancient Syriac Documents at the St. Petersburg Public Library). ${ }^{6}$ Well informed of the fact that the genre of apocrypha took its origin in religious lore and myths, he nevertheless approached Acta apostolorum apocrypha (Apocryphal Acts of the Apostles) as historically valuable, written rather than oral sources. According to his interpretation of the "Acts," oral substratum preserved by the contents of apocrypha provided a distinctive picture of the cultural situation in the early Christian era. Zhebelev found cultural analogues to the apocryphal Acts in the secular genres of ancient literature-travelogues, biographies, the Lives of the Greek philosophers-a wide range of documents, none of which had been reputed to be a reliable historical source. ${ }^{7}$ Following Schmidt and Lipsius, Zhebelev used religious legends and apocrypha to double-check the historical facts which he then reinstalled into his "general survey" (obshchii ocherk) of the Apostle Paul's life. He mapped out the routes of Paul's missionary travels and reconstructed the story of his imprisonment, transfer to Rome, and his subsequent execution there.

In discussing the Pauline teachings Zhebelev further distinguished between the oral and the written traditions: he juxtaposed echoes of Judaic synagogal oration and reminiscences of Hellenistic rhetorical and philosophical art. For instance, in his chapter "The Epistles of Apostle

${ }^{6}$ For his study Zhebelev used the following sources: Karl Schmidt, Reliquienkult im Altertum (Giessen, 1909) and Acta apostolorum apocrypha, ed. Tischendorf et al. One of the St. Petersburg manuscripts, which consisted of 142 leaves, also included an apocryphal "History of Thecla, Disciple of St. Paul the Apostle" (Zhebelev, Apostol Pavel, 49-51); see also William Wright, Apocryphal Acts of the Apostles, Edited from Syriac Manuscripts in the British Museum and Other Libraries with English Translations and Notes (Amsterdam: Philo Press, 1968). For other versions of the apocryphal Acts of Paul and Thecla, see also Wilhelm Schneemelcher and A. J. B. Higgins, eds. and trans., New Testament Apocrypha (Philadelphia: Westminster Press, 1963), 2: 353-64.

${ }^{7}$ Zhebelev strengthened the power of his arguments by referring to the authority of Eduard Norden. Zhebelev, Apostol Pavel, 17-20, 22, 57, 152-53. 
Paul as a Historical and Literary Monument" he discussed the Epistles as a specifically written form of communication whose style, however, reflected the author's intention of establishing direct contact with his immediate audience-the people who had come to listen to his preaching. ${ }^{8}$ As Zhebelev stated, the Pauline epistles did not meet the stylistic standards of written communications and were composed in a manner commensurate with the diverse educational levels and cultural backgrounds of the multinational communities he addressed. Paul's deliberate uncouthness and negligence regarding unity of style were indispensable to his mission of delivering and disseminating the fundamentals of the new faith among this heterogeneous congregation. The ideational stance of the Pauline "tidings" was as nonhomogenous as its style. It recombined and dialectically modified the Roman idea of universal monarchy, Hellenistic cosmopolitanism, and Judaistic notions of wisdom and the "knowledge of God" as they derived from the Second Book of Chronicles and from the teachings of the Stoics. In the apostle's teachings, these ideas were complemented by the knowledge of Christ's life which Paul had gotten from the disciples, from legends, and from authoritative doctrinal sources. ${ }^{9}$

Assisting Zhebelev in his research and preparing a commentary to his New Testament Apocrypha, Freidenberg adapted as well as "adopted" her teacher's talent for recombining facts obtained from diverse nonhomogenous sources. Working from Zhebelev's supposition on the role of oral traditions and pagan beliefs in the dissemination of Christian teachings, Freidenberg broadened the theoretical framework of her study and developed a "revolutionary" approach to verbal arts and archaic folklore. ${ }^{10}$ Where Zhebelev surmised analogies between early Christian and Pythagorean teachings, Freidenberg obliterated differentiations and postulated antinomic identities:

Death and resurrection-that was the unconscious demand of the Christians' literature, which was just coming into being. Immortality and the eternal life of the soul was the statement of the neo-Pythagoreans (Porphyr, Vita Pythagor). Christ here,

\footnotetext{
${ }^{8}$ Zhebelev, Apostol Pavel, 121-58.

${ }^{9}$ Ibid., 134, 144-47, 161.

${ }^{10}$ In her letter to the Collegium of the Scientific Research Institute of Comparative History of Languages and Literatures of the West and East (ILIaZV), 30 March 1924, 1 (unpublished), Freidenberg insisted on the agreement between the political demands of the era and the spirit of her study: "My work, conducted during the five-year span 1919-23, was undertaken in the conditions of revolutionary times, and is to be treated in accord with the time's spirit and the meaning of the results achieved" ( $i$ otnoshenie $k$ nei dolzhno byt' sootvetstvuiushchee ee kharakteru i ee vypolneniiu).
} 
Dionysus there - both [systems-N. P.] needed the Greek novel, which had brought forth the necessary hero, but remained as yet void of content.

Смерть и воскресение - вот бессознательный запрос нарождающейся литературы христиан; бессмертие и вечная жизнь души - ново-пифаготейцев (Porphyr., Vita Pythagor). Христос там, здесь - Дионис: им нужен греческий роман, у которого есть именно такой герой, но еще нет содержания. ${ }^{11}$

Freidenberg looked closely at the correspondence between the vital demands of the early Christian era and the ancient, not-yet-formalized, proto-Christian genres through which these beliefs were expressed: "Although isolated individual features of Thecla's story corresponded to certain characteristics of the Christian apocryphal and canonical Acts, Martyrium, and Lives of the Saints, none of the ancient Christian genres provided analogues to the 'Acts of Paul and Thecla' in toto." Having ascertained this, Freidenberg transferred her attention to the "compositional formants," or morphemes which conveyed the basic meaning of the tale. Here she observed that the morphemes providing the general formula for Thecla's martyrdom duplicated the compositional formants of the Acts and Martyrium (both apocryphal and canonical).

Whether it is a tale of persecutions, of feats, martyrdom, or passions, everywhere we find in the center a heroic deed and victimization, a situation of journey and wandering; everywhere we find sufferance and death in torment. However, we find Martyrium in the form of Lives, as a condensed tale, an account of suffering, while various deeds [a vsiakogo roda deianiia] are rendered in the form of lively depictions which present the occurrences step by step, as if a series of moving-pictures [ $k a k$ by $v$ peredvigaiushcheisia dekoratsii]. ${ }^{12}$

Freidenberg's metaphor "a series of moving-pictures" makes one understand that the primary goal of her scholarly research was fundamentally different from Zhebelev's objectives. She sought a broad interpretative framework for her apocrypha and included free associations with modernity into her analysis of the ancient text. Freidenberg projected "a tale of persecutions" (as she now called "The Life of Thecla") against a new ideological and epistemological background. Zhebelev, conversely, realized clearly that he worked on his book during a time when the Bolshevik regime had grown aggressive toward the "oldregime" intellectuals. He was content to limit his religious and academic

\footnotetext{
11 Freidenberg, "Proiskhozhdenie grecheskogo romana," 208.

12 Ibid., 35-36.
} 
ambitions to introducing Christology and Christian theology as an auxiliary discipline which used theory of literary styles to unite Classical philology and history of religion. Quite intentionally, he assumed a pose of humility by publishing his book under the subtitle, "general survey," obshchii ocherk, and playing down precisely those assertions which Freidenberg found of cardinal importance for her own work.

Freidenberg fundamentally modified Zhebelev's interpretation of Paul's intention to affect the spiritual expectations of his non-Christian listeners. Instead of the religious proselytism of individuals, she primarily discussed the beliefs of pagan communities. She developed Zhebelev's marginal observations on the oral substratum of the early Christian apocrypha, and included in her study a large number of pagan texts and myths whose plots and composition provided analogues to the thematics, plot structure, and composition of Christian legends which treated the proselytes' martyrdoms, miraculous releases, deaths, and resurrections. She analyzed in detail the pagan substratum of the Graeco-Phoenician area, and when treating affinities between the genres of the apocrypha and ancient Greek novels, she utilized the morphology of these ancient myths.

Freidenberg's dissertation had its origin not only in the writings of Zhebelev, but also in the studies of Eduard Norden and Adolf von Harnack. Over the next two years she reworked it into a broader study, "The Greek Novel as Acts and Passions" ("Grecheskii roman kak deianiia i strasti"), but her attempts to publish the work remained unsuccessful. In 1926, her uncle Leonid Pasternak, who was working on a portrait of Adolf von Harnack, brought Freidenberg's manuscript to the attention of this world-renowned scholar. After the latter returned a very favorable review of the work, a relatively lengthy excerpt entitled "The Gospel-One Type of Greek Novel" was published by The Atheist, a monthly publication of the All-Union Society of Militant Agnostics. ${ }^{13}$ Nevertheless, her related study, "Aselliana," or "Entry into Jerusalem upon an Ass (From the Mythology of the Gospels)" ("V"ezd v Ierusalim na osle [Iz evangel'skoi mifologii]," 1923, reworked in 1930), had to wait almost 50 more years for publication. ${ }^{14}$

13 O. Freidenberg, "Evangelie-odin iz vidov grecheskogo romana," Ateist 59 (1930): 29-47.

${ }^{14}$ In his letter to Leonid Pasternak (28 October 1926) Harnack said that although he was "overburdened with all sorts of duties," he had read Freidenberg's paper immediately and found that "it is convincing as well as correct in its main conclusions, and thus indicates a step forward in the literary understanding of the Acts of Paul and Thecla" (Race of Life, 4: 3-4). For a synoptic account of Freidenberg's work, see Mossman, Correspondence, 64, 76-77. For a 
Freidenberg's master's thesis can be taken as a case study revealing both the general trends and everyday life of the humanities in early post-revolutionary times. Thanks to Zhebelev's support, Freidenberg received special permission to work with esoteric manuscripts, rare handbooks, and theoretical studies from the Petrograd Public Library; but archival holdings from Moscow and the proceedings of universities from other republics (such as Baku University, where Viacheslav Ivanov published his Dionis i Pradionisiistvo) were not available to her. ${ }^{15}$ She likewise had no access to Western scholarly publications of the $1920 \mathrm{~s}$.

\section{Tracing Similarities between the Early Christian Apocrypha and the Ancient Greek Erotic Novel}

Freidenberg began her thesis with a summary translation of the apocrypha. ${ }^{16}$ Regarding the contents of the apocryphal tale, Freidenberg wrote: "We find a hero [the apostle Paul-N. P.] endowed with a supernatural spiritual force undertaking many spiritual deeds in a situation of traveling." The hero is brought by a hostile mob to the Hegemon's council and subjected to an unjust trial. He is bound, thrown into prison, and then cast out of the city. In all the episodes of the apocrypha, the role of female personages is very significant:

At the center is Thecla, the virgin. Theocleia, her mother, inflicts the first ordeals on Thecla; Tryphaena, who constantly talks about her deceased daughter, follows Thecla to the theater in the episodes when the latter is thrown to fight with the wild beasts.

detailed account of her struggle with the academic bureaucracy, see Race of Life, 3: 45-49; 7: 55-88, 97-104. See also "V"ezd v Ierusalim na osle (Iz evangel'skoi mifologii)," Mif i literatura drevnosti, 623-65.

${ }^{15}$ Beginning in 1922, the Commissariat of Public Enlightenment accepted for publication only studies produced by faculty of the State Universities. In order to secure permission for publication of Dionysus and Pre-Dionysianism, Viacheslav Ivanovich Ivanov, the cultural leader of Russian Symbolism, had to seek academic affiliations with Baku State University and submit his study for an official Ph.D. defense. See G. Ch. Guseinov and N. V. Kotrelev, "Primechaniia k rabotam Viach. Ivanova," in: Eskhil, Tragedii. $V$ perevodakh Viacheslava Ivanova (Moscow: Nauka, 1989), 560-61.

16 "Proiskhozhdenie grecheskogo romana," 18-43. Freidenberg's Russian translation differs from the English translation by William Wright. She provides an interlinear word-for-word translation, sacrifices the pagan exotic flavor of the narrative, and avoids the patterned repetitions and phraseologisms (later interpolations) typical of Christian written style: "The Lord Jesus the Messiah"; "The Lord rose up thence and ascended onto heaven" (Wright, 128, 136). Fragments containing Thecla's prayer to God are also missing from Freidenberg's translation. 
In another episode, a crowd of women sympathizes with all of Thecla's acts and for some unknown reason rescues her. In yet another scene, women throw wood onto a fire in order to burn Thecla. Even Thecla's main protector among the beasts is a lioness who fights other animals for her, while Thecla, unharmed, remains at a distance: it's the female nature of the beast which accepts pain and death in her stead. ${ }^{17}$

The exceptional role played by women "in the apostolic and subapostolic age" and the manner in which apocrypha depicted their prominence in teaching Christianity had already been discussed by Adolf Harnack, who formulated his conclusion in the most unequivocal manner: "It is quite clear ... that women appeared in the local assemblies of the church and ... that they prayed and prophesied in public."18 In his discussion of the "inward spread of Christianity among women," however, Harnack had no intention of foregrounding the feminist reading of the Epistles and Acts. Freidenberg, who followed Harnack's interpretations, did not have this intention either. What can be mistaken for a manifestation of "feminist discourse" in her analysis of "The Acts of Paul and Thecla" provides further evidence of her thorough knowledge of Veselovskii's writings on the archaic matriarchal period of human history: his anthropological studies of "Mother Earth" cults and their cultural survivals in later patriarchal pagan myths and Christian religious rites. ${ }^{19}$

Consciously, Freidenberg was indifferent to the feminist ideas of her era, but intimately, musing over her own destiny, she viewed her position as a student vis-à-vis Professor Zhebelev through the prism of the old apocrypha, and recognized in the images and symbols of the analyzed text situations comparable to her own life. Thus, there exists an intentional parallelism between the episodes from her memoirs and those from the apocrypha in which both teachers (Zhebelev and Paul)

17 "Proiskhozhdenie grecheskogo romana," 37.

18 Adolf Harnack, The Mission and Expansion of Christianity in the First Three Centuries, trans. and ed. James Moffatt (New York: G. P. Putnam, 1908), 2: 64, 65; see also 2: 64-84.

19 A. N. Veselovskii, Istoricheskaia poetika (Leningrad: Khudozhestvennaia literatura, 1940), 571-85. Veselovskii's writings on couvada (ibid.) present another interesting case of a pseudo-feminist criticism. Beginning in the late $1870 \mathrm{~s}$, inspired by Veselovskii, the leading Russian historians and anthropologists V. Latyshev, M. Kovalevskii, and D. Zelenin wrote intensively on different aspects of matriarchate and "Mother Right." After the revolution an intensive study of matriarchate was undertaken by Nikolai Iakovlevich Marr and his group. 
refuse to help the young female proselytes and subject to trial their moral fortitude and faith. ${ }^{20}$

The apocrypha incorporated many historically disputable and poorly coordinated episodes, such as the scene in which Thecla baptizes herself by casting herself into a great pit of water with marine seals in it. While the heroine employs the formula for a baptismal vow which had been known from the days of Christ and from the canonical Acts of the Apostles, the rite of self-baptism, as Freidenberg correctly observed, was not to be found in any ecclesiastical tradition. Thus, the framework of the apocrypha had preserved components of archaic pagan plot structures which were later revamped in the spirit of Christianity.

Another group of incongruent episodes was related to Thecla's extraordinary beauty and virginity, as well as to her unreserved willingness to submit to ordeals and suffering in order to remain true to Paul and follow him. Sensual or physical beauty had no value in early Christian sources; and if the tale represented Thecla's extraordinary beauty and virginity as virtues, it meant that the apocrypha was investing these qualities with a connotation originating in pre-Christian texts. Resisting a rapist, Thecla calls herself the "handmaid of God," a "hierodule," that is, a temple slave who serves God with her purity. Rather than the heroine's virginity, her chastity and purity informed the plot of the apocrypha; and as Freidenberg insisted, these elements were first articulated and associated with one another in Greek erotic novels: the Ethiopian Story by Heliodorus, the anonymous Chion and Heraclea, and novels by Achilles Tatius, Xenophon Ephesius, and other erotici scriptores. ${ }^{21}$

Both the apocrypha and the Ancient Greek erotic novels can be synopsized according to the same scheme. The adventures and ordeals of the ancient heroes dovetail with the plot structures of Christian Martyrdoms and Passions: "Morphologically, Thecla's individual features turn out to be the most characteristic traits of the heroine of the Greek novel." ${ }^{22}$

${ }^{20}$ Cf.: Race of Life, where Zhebelev, impressed by the persuasiveness of Freidenberg's conclusions about the function of pagan elements of the plot in the genre of Christian apocrypha, repents publicly: "I tormented her! I made her undertake a dull, difficult and fruitless job! But she withstood all the temptations" (no ona odolevala vse iskusy) (2: 126) and "Acts of Paul and Thecla" (line 25) in Freidenberg's translation, where Paul at first leaves Thecla alone in the hands of a cruel governor and wild crowd who condemn her to be burned, and then, rejoicing in her miraculous escape from the torment of fire, exclaims: "The season is heinous, and you are comely. May no other temptation come upon you" (vremia postydnoe, a ty prekrasna soboi: ne vzialo by tebia drugoe iskushenie).

${ }^{21}$ Freidenberg, "Proiskhozhdenie grecheskogo romana," 43. See also chap. 1, "Elective Affinities," **.

22 Freidenberg, "Proiskhozhdenie grecheskogo romana," 43-44. 
Freidenberg further asserts a morphological identity between travel adventures, on one hand, and the journeys of homage and ordeals of religious proselytes, on the other; she also considers the situation of the hero's presumed death or departure in Greek romance as an analogue to death and resurrection in religious legends and evangelistic texts. Having demonstrated similarities in plot structures between Christian apocryphal and Greek secular genres, Freidenberg establishes affinities between this group of texts and those of archaic myths of dormition (departure from life) and awakening (return). She argues that the framework of the "Mother Earth" and Isis-Osyris cycle was also comprised of life/death metamorphoses. Freidenberg concluded her thesis with the following statement:

Like Hellenism, which met all the expectations of the not-yet shaped-genre, the early Christian era found all the preconditions it sought in the elements of the Greek novel, and this enabled it to transmute its own [Christian-N. P.] contents into what had originated from the same roots with it. This is how the Lives of the Saints with the plot structure of the Greek erotic novel were created. This is how the tale of the heroine of Achilles Tatius, who married the hero, brought about "the second part of the novel," although an already ecclesiastic, Christian Galactio et Epistema. At one time, the alternation of the seasons, of day and night, of life and death related to one's leaving and arrival; to the eternal vortex of joy and sorrow, to withering and blossoming. Ritual and religion brought to life legends which canonized their sacral plots.

When the gates of all nations were opened, there began to arrive from everywhere identical representations of the declining and rising luminaries, of the death and blossoming of tender vegetation, of bread grains, of handsome youths, which were envisioned as a bounty generated by the sepulchral darkness, as the eternal revolving of up-and-down movement, as the gifts of death and loss of life. Different nationalities and confessional denominations only varied the motifs which were layered over this archaic framework; yet everybody believed in the basic foundations....Ver corporis is the contents of the Greek novel. ${ }^{23}$

The most essential observations suggested by Freidenberg as early as 1924 later became known in the West independently via the writings of classicists and theorists working in literature, folklore, and cultural studies: Karl Kerényi, Northrop Frye, B. E. Perry, and Reinhold Merkelbach, as well as Denys Page and Pierre Saintyves (whose 1922 
publication did not reach Russia until 1925). ${ }^{24}$ In The Form of Greek Romance Bryan P. Reardon provides "a view of the pattern of romance in general" which points out affinities and draws distinctions between the ideas of these scholars. ${ }^{25}$ One has to remember, however, that Reardon summarizes the greatest achievements of more than fifty years of Classical studies. More significantly, all the above-mentioned authors (with the exception of Northrop Frye) offer two parallel planes of typological affinities: one, the treatment of the Greek novel in its context, among other works and genres-such as epic, drama, and historiography - whose textual fabric possesses elements comparable to the basic morphemes of ancient romance (E. Rohde, B. E. Perry), and two, the establishment of connections between the Greek novel and the standard features of works "in which gods do regularly manifest their goodwill to men and their prowess"-such as myths, aretalogy, religious legends, and "fanciful historiography and biography," including early Christian apocrypha (Karl Kerényi, R. Reitzenstein, Bryan P. Reardon.) ${ }^{26}$

Unlike these authors, Freidenberg offers a model that is reminiscent of an equilateral triangle: archaic myth - Greek novel - early Christian apocrypha, in which every side represents an individual mode of perception and representation of reality. The allegorical formula "Ver corporis," which for Freidenberg summarized "the contents of the Greek novel," can be best compared in this sense to the allegorical expression "the Mythos of Summer," by which Northrop Frye indicated the integral sum of the elements lending literary form to "the romance." "The complete form of the romance," writes Frye, "is clearly the successful quest, and such a completed form has three main stages: the stage of the per-

${ }^{24}$ Karl Kerényi, Die Griechisch-Orientalische Romanliteratur in religionsgeschichtlicher Beleuchtung (Tübingen, 1927) (here references are to the second, revised edition: Karl Kerenyi, Die Griechisch-Orientalische Romanliteratur in religionsgeschichtlicher Beleuchtung: Ein Versuch mit Nachbetrachtung [Darmstadt: Wissenschaftliche Buchgessellschaft, 1962]);; Northrop Frye, The Secular Scripture: A Study of the Structure of Romance (Cambridge: Harvard University Press, 1976); B. E. Perry, "Chariton and his Romance from a Literary-Historical Point of View," American Journal of Philology 51 (1930): 93-134; Reinhold Merkelbach, Roman und Mysterium in der Antike (Munich: Beck, 1962); Denys Page, The Homeric Odyssey (Oxford: Clarendon Press, 1955); Pierre Saintyves, Essais de folklore biblique: Magie. mythes, et miracles dans l'Ancien et le Nouveau Testament (Paris: E. Nourry, 1922).

25 Bryan P. Reardon, The Form of Greek Romance (Princeton: Princeton University Press, 1991). For a thorough discussion of the above problems, see "The Practice of Greek Romance," 15-45; "Context and Contacts," 127-68; and the concluding chapter, "The Pattern of Romance," 169-80. For the interpretative scheme, see 174 .

26 Ibid., 128, 141, 153, 160. 
ilous journey and the preliminary minor adventures; the crucial struggle, usually some kind of battle in which either the hero or his foe, or both, must die; and the exaltation of the hero.... The hero of romance is analogous to the mythical Messiah or deliverer who comes from an upper world, and his enemy is analogous to the demonic powers of a lower world. The conflict, however, takes place in, or at any rate primarily concerns, our world, which is in the middle and which is characterized by the cyclical movement of nature. Hence the opposite poles of the cycles of nature are assimilated to the opposition of the hero and his enemy. The enemy is associated with winter, darkness, confusion, sterility, moribund life, and old age, and the hero with spring, dawn, order, fertility, vigor, and youth." ${ }^{27}$ In Freidenberg's thesis one finds all of the associations and symbolic identifications mentioned by Frye: Thamyris, Thecla's malevolent betrothed, who denounces Paul, remains completely unloved and dies a lonely death, while Thecla, miraculously protected by God in prison, in the fire, and among the wild animals, goes from place to place, teaching love, peace, and bringing good tidings and great joy to every house.

\section{Freidenberg's Conflict with Her University Teachers}

One has to project the ideas Freidenberg articulated in her master's thesis onto the background of the 1920 s to really appreciate them. Moreover, the reaction to her work-the very limited support her views were given and the great degree of skepticism directed at her suppositions-can provide insight into the history of the humanities in Russia.

The classicists of the 1920 s who introduced Freidenberg to their synthetic approaches to the history of ideas and religious studies-Sergei Zhebelev, Ivan Tolstoi, and Grigorii Tsereteli-operated with cultures that had already completed their cycles of development. In their works the opportunity justifiably to consider Classical languages, literatures, and cultures as finalized objects of academic investigation became a methodological advantage; it enabled them to compare the dynamic process of culture (energeia) with the final result (ergon) obtained through the course of development. Experts in modern cultures insisted on mutually exclusive, synchronic/diachronic and synthetic/analytic methods, yet the Classicists and the Slavists with whom Freidenberg worked in 1918-23, while remaining adamant about the validity of the "facts" and their positivistic interpretations, favored a combined analytical and synthetic approach and correlated a diachronic interpretation of literary

27 Northrop Frye, Anatomy of Criticism: Four Essays (Princeton: Princeton University Press, 1971), 187-88. 
monuments with the synchronic study of the ethnographic and cultural data of the past. Adherents of positivism, they frequently summarized their academic observations in surveys: "ocherk" was the most frequent subtitle of their scholarly works. ${ }^{28}$ Freidenberg's teachers did not yet distinguish between, on the one hand, the intellectualism and euhemerism $^{29}$ in their treatment of myths and legends, and, on the other, the objective representation of reality these monuments had preserved in their textual fabric. Their hybrid methods embraced Edward Tylor's doctrine of uniform mental development, Frazer's anthropological and comparativist approach to myth, Herman Usener's interpretation of the antinomies of the Greek myths, and Norden's and Harnack's Christology. ${ }^{30}$ In Russian philology they succeeded in reconciling two competing theoretical trends: one syncretic, originating in Veselovskii, and another psychological, developed by Potebnia. ${ }^{31}$ In their analyses of Christian sources, Freidenberg's teachers acknowledged the "superiority" of written forms over oral cultural traditions. In their analyses of archaic folklore, they treated myths on the death and resurrection of pagan deities as effaced or precursory forms of Christian messianic writings. Freidenberg, conversely, projected an individual group of Christian apocrypha onto the massive background of oral culture.

Following Veselovskii and Usener, Freidenberg's teachers proceeded from the assertion that Christianity had absorbed and transformed (under the aegis of "spiritual individualism," as Zhebelev said) certain epistemological premises of Hellenism and Judaism, and in this sense religious postulates of pre-Christian doctrines had contributed to the creation of a new system. Freidenberg read Christian legends and the

${ }^{28}$ In addition to Zhebelev's survey (ocherk) on the Apostle Paul, see the voluminous study of Aleksandr Kornil'evich Borozdin, Protopop Avvakum: Ocherki po istorii umstvennoi zhizni russkogo obshchestva $v 17$ veke (St. Petersburg, 1900). Freidenberg took a seminar in Russian heresiology from Borozdin and learned from him how to juxtapose, without clashing them against one another, textual and historical criticism, and evolutionary and syncretic approaches.

29 Euhemerism (from Euhemeros, a Greek philosopher of the 4th century B.C.) explains myths rationalistically, as being founded on the basis of history or deification of the heroes.

${ }^{30}$ For the most complete overview of the history of mythography in the West, see Robert Ackerman, The Myth and Ritual School: J.G. Frazer and the Cambridge Ritualists (New York and London: Garland, 1991), 29-67, 118-59.

31 For a thorough discussion of Veselovskii, Potebnia, and their theories, see Akademicheskie shkoly $v$ russkom literaturovedenii, ed. N. F. Belchikov (Moscow: Nauka, 1975), 202-80, 303-62; for the discussion of a VeselovskiiPotebnia ingot molded by the Petrograd Classicists into a new synthetic approach to ancient cultures, see my "Ol'ga Freidenberg on Myth, Folklore, and Literature," 372-74. 
Gospels as "transcriptions" of multifaceted and colorful pagan myths. She underscored the role of Antiquity in the morphology of marginal figures from Christian apocrypha; she put additional emphasis on experientially, pragmatically observed occurrences and metaphysically interpreted schemes of the ancient universe, which together revealed the same underlying world picture (kartina mira). Freidenberg made this aggregate image-concept of pagan mythology comparable to the masterplots of early evangelism and the fabulous stories of Christian virtues and continence.

Quite unintentionally, Freidenberg located her study at the crossroads of two analytical directions which were about to gain authority in folklore and philosophical anthropology: one originating in the morphological analysis of plots (Joseph Bedier, Antti Aarne, Jiří Polivka, Vladimir Propp), another in Adolf von Harnack's philosophy of religion. Harnack stated that in early Christianity "each symbol has a mysterious but real connection with the fact which it signifies," and he interpreted the Pauline teachings and the book of Revelation as "the combination of the mysterious realistic elements with the spiritual ... which have a reciprocal knowledge of each other's essence and thus are absorbed in one another." 32 Both Propp and Harnack would eventually become familiar with Freidenberg's scholarship and appreciate her approach. ${ }^{33}$ In 1923 24 , however, the incipient junction of the two trends was not quite clear to Freidenberg herself, and the latent advantages of her approach had yet to be proven.

For as much as Freidenberg aimed to define patterns that recurred on an atemporal and acausal basis in different plots, she deviated from Harnack's and Veselovskii's intellectualist interpretation of plots and motifs in her search for the smallest indivisible elements underlying archaic myths, novels, and folk legends. In her thesis she named these recurring formulaic components "myth transcriptions," yet she failed to articulate the meaning of her term "transcription." ${ }^{34}$ In 1924 it still remained unknown to her which individual components of archaic myths lent themselves to "transcription" and became recast as the constituents of newer cultural texts.

One should emphasize that Freidenberg was not the only one who strove to answer the question of which particular components of archaic structures are "transformable." It is indicative that shortly before the publication of the Morphology of the Folktale (Morfologiia skazki, 1928), Propp wrote his "Transformations of the Wondertale," in which he was not yet able to delineate the indispensable and self-sufficient stable ele-

32 Harnack, Mission and Expansion, 1: 228, 231.

33 On Propp and Freidenberg, see chap. 6 of this study.

${ }^{34}$ Freidenberg, "Proiskhozhdenie grecheskogo romana," 71, 72. 
ment of the plots in these tales (what he will define as "function" in Morphology of the Folktale); and he therefore, exactly like Freidenberg, tried to analyze those components which undergo transformations: reduction, amplification, intensification, substitution, modification, and assimilation. ${ }^{35}$ His "function," conversely, pointed to the stable elements of the tales' plots-those which do not depend on the characters who perform actions. In Morphology of the Folktale, "function" was described as "an act of a character defined from the point of view of its significance for the course of the action." ${ }^{36}$ Propp's "function" suggested an analytical procedure comparing the plot-structures of the same genre. In Morphology of the Folktale Propp emphasized the significance of deductive, empirical, synchronic approaches, whereas in "Transformations of the Wondertale" he relied on the validity of evolutionary, diachronic, and organic approaches. ${ }^{37}$ As if hoping to reconcile the opposite analytical strategies used by Propp in "Transformations of the Wondertale" and in Morphology of the Folktale, Freidenberg in her "Origin of the Greek Novel" proposed a combination of syntagmatic, empirical, and inductive, rather than deductive approaches. ${ }^{38}$ Propp moved from one plot structure to another within the limits of the same genre, and therefore could easily demonstrate different meanings given to a function in the course of action. Freidenberg, by contrast, adopted Harnack's method of intellectual induction, and this made her

35 V. Ia. Propp, “Transformatsii volshebnykh skazok," Poetika 4 (1927): 71, 7886. Morphology of the Folktale had been completed but not published by this time. Thus Propp referred to his own synopsis of this work in "Transformatsii," 70.

${ }^{36}$ V. Ia. Propp, Morfologiia skazki (Moscow: Nauka, 1969). For an English translation, see Morphology of the Folktale, trans. Laurence Scott, ed. Louis A. Wagner (Austin and London: University of Texas Press, 1968), 21, 68.

37 Propp, "Transformatsii volshebnykh skazok," 72-77. Consider, in particular, his phrase: "The basic forms are those that are related to the genesis of the tale" (73).

${ }^{38}$ For a recent attempt to apply Morphology of the Folktale to "a sphere wider than that of folklore," see Consuelo Ruiz-Montero, "The Structural Pattern of the Ancient Greek Romance and the Morphology of the Folktale of V. Propp," Fabula 22 (1981): 228-38. Unaware of Freidenberg's study of the Ancient Greek romance and of Propp's "Transformatsii volshebnykh skazok," the author introduces "a theoretical model which only exists on a paradigmatic level" and which enables one to distinguish "the double morphological meaning of a single function." The structural components of the Ancient Greek romance that run across genre boundaries and whose morphological meanings undergo transformation are: "assimilation," "contamination," and "weakening and intensification of functions." Thus, unbeknownst to Ruiz-Montero, her theoretical model duplicates the pattern suggested by Freidenberg and Propp in the 1920s. 
understand that in the early Christian era "the mental standpoint of the age and its religious needs were so manifold that it was unwilling to forgo any form, even in Christianity, which was capable of transmitting anything of religious value." ${ }^{39}$ She presumed that intergeneric comparative analysis would be comparable to intrageneric plot analysis-a presumption which weakened her sequential treatment of mythological forms. Propp, most likely because he was aware of this unavoidable deficiency in the transformational method, limited himself to providing only a brief account of the possible substitutions of wondertale morphemes: he mentioned "confessional substitution, archaic substitution, and literary substitution," but he did not take up the process of genre transformations. ${ }^{40}$

Freidenberg regrouped mythological elements both across and along different genres of collective lore. This made it possible for her to demonstrate that at the time when the Christian apocrypha came into being, all the manifold standpoints and all the innumerable mysteries already known to people were provided a uniform interpretation: this is how she attained her understanding of earthly and divine love, divine marriage, death, and resurrection in different genres. What Freidenberg sought to define as "transcriptions" were the primordial elements (archetypes) of all myth-formations: water, bread (sprouts, shoots, grains, seeds), wine (grapes, grape juice), death, and rising from death. Treating "the elements of water, bread, and wine" as universal symbols and introducing them as components of mythological plots and motifs, as emblems of pagan deities and acronyms of their names, Freidenberg followed Harnack's interpretations. ${ }^{41}$ Her transcriptions represented "everything that was known as symbols of polytheist doctrines," and retained formal value as parts of a new concept. Each transcription, or (to continue with Harnack's definition) "each symbol had a mysterious but real connection with the fact which it signified." ${ }^{2}$ Freidenberg's thorough knowledge of Harnack firmed up her understanding of Christian teleology, while a reliance on the genetic approach protected her study from teleological encroachments. To be true to the spirit of the letter, Freidenberg's proposal for a combined syntagmatic and paradigmatic approach (as we say nowadays, in the age of Greimas, Lévi-Strauss, and Coseriu) was not clearly articulated in her dissertation for the simple reason that the required concepts and terminological definitions did not yet exist in the humanities of the 1920s, and this insufficiency in the

\footnotetext{
${ }^{39}$ Harnack, Mission and Expansion, 1: 228.

40 Propp, "Transformatsiii volshebnykh skazok," 81-82.

41 Harnack, Mission and Expansion, 1: 228.

42 Ibid.
} 
conventional terminological apparatus presented an additional hindrance in understanding her work.

Freidenberg's university teachers, while interested in archaic folklore, were studying the morphogenesis of literary forms, and their willingness to accept the validity of her innovations always remained within the boundaries of the "anthropology of origins" as suggested by Edward Tylor in Primitive Culture and Anthropology $(1871,1881) .{ }^{43}$ Zhebelev was himself a refined interpreter of Tylor's, Usener's, and Veselovskii's systems of reiterated motifs, which provided symbolic forms for the organization of the peoples' agrarian, religious, and societal traditions. ${ }^{44}$ He supported Freidenberg when she recognized in the narrative of the apocryphal Acts a syncretic substratum akin to the pre-form of the Greek novel, which, in its turn, had its roots in "Babylon, Egypt, Asia Minor and the isles ... formerly the region of a homogenous myth culture whose carcass predated the framework for the novel." 45 Among his colleagues Zhebelev enjoyed the nickname "factographer"; he always privileged facts over concepts and approached the evolution of the arts and cultures from the position of taxonomy. ${ }^{46}$ One can surmise that his personal adherence to positivism made Christian teleology commensurate with his own religious intuition, and that it also influenced his "tendency to value the cognitive component of religion (beliefs and intentions) at the expense of the performative (rites and ceremonies)."47 Thus, several of Freidenberg's premises, such as her statement that ancient aretalogy had preshaped the concept of miracles in Christian doctrine, or her tracing of the affinities between the Greek love story (romance, erotic novel) and an apocryphal Christian legend, seemed acceptable in his view. An erudite historian of Hellenistic, Roman, and early Christian cultures, he was quite well informed about the pagan mythological substratum in Christianity, but in terms of ontology, he refused to treat Christian religion as "a mythology" on par with ancient mythology; for, according to his world view, the former concept had the meaning of a theological tradition, rather than of legendary lore. Thus,

43 For Tylor's contributions to the study of the prehistory of mankind, see Ackerman, The Myth and Ritual School, 36-59.

44 A student of the forms of historical consciousness, Veselovskii is defined as the "Russian Tylor." See M. B. Pliukhanova, "Veselovskii kak issledovatel' form istoricheskogo soznaniia," in Nasledie Aleksandra Veselovskogo: Issledovaniia $i$ materialy, ed. P. Zaborov (St. Petersburg: Nauka, 1992), 40.

45 Freidenberg, "Proiskhozhdenie grecheskogo romana," 93.

${ }^{46}$ Freidenberg, Race of Life, 2: 47.

47 This characteristic of Zhebelev's positivism is borrowed from Ackerman's definition of Tylor's anthropological position. Ackerman, The Myth and Ritual School, 36. 
when Freidenberg proposed to incorporate into her thesis (as an illustration for what she termed "an antinomic identity") the results obtained from her two papers, one revealing in Odysseus's journeys the semantics of death (the hero's visit to Hades), and another treating an ass as a symbol of salvation in proto-Christian and Gospel mythology ("Asseliana," 1923), Zhebelev said: "All right, but remove the episode from the Gospels!" (3: 64). ${ }^{48}$

The so-called "Eselsroman" had been abundantly discussed in scholarly literature, and soon after Freidenberg had completed her thesis, Kerényi dedicated three lengthy chapters of his book to this subject. According to Kerényi, the redemption of a hero who has been transformed by witchcraft into an ass, as in Lucian, Apuleius, and Petronius, revealed a compatability with various monastic stories; and medieval Christian religious processions (such as that of "Corpus Christi" in fourteenth-century Europe) preserved elements of the man-in-animalshape fable. Kerényi also wrote about the protogenetic unity of the Eselsroman, the Greek erotic tale, and the Epiphany ceremonies of Roman and Christian times. ${ }^{49}$ Within this chronological framework, Kerényi discussed polytheistic pagan cultures as vestiges preserved at the periphery of Christian religious folklore. Freidenberg projected her study onto this intercultural spatial and temporal dimension, and from that dimension she extrapolated the core concept of Christian tradition.

It is rather unlikely that Zhebelev felt embarrassed by Freidenberg's "Ovolatria," or had religious reservations about her attempts to reconstruct the common world picture out of which were born Old Testament and Christian religions; after all, he shared the professorship at the Classical Department with the well-known Symbolist scholar and advocate of Nietzsche, Tadeusz Zielinsky. But as a rigorist in academic formalities, Zhebelev believed that Freidenberg's innovations were absolutely incompatible with the thesis requirements for a student seeking a master's degree in classical philology. Freidenberg's desire to have an official dissertation defense during a time when programs in classical philology were being sharply curtailed by the state struck him as untimely and ambitious. Freidenberg herself described the situation thus:

The very word "dissertation" sounded like a monster. Terms related to the old standards of life (democracy, officer, especially-

48 In Freidenberg's first curriculum vitae (which she copied into The Race of Life), "Literary Genesis of the Odyssey" (1922) and "An Ass-Symbol of Salvation" (1923) are listed as individual entries (3: 61). The papers were published later as "Siuzhetnaia semantika Odissei" (Iazyk i literatura 4 [1929]: 59$74)$ and "V"ezd v Ierusalim na osle (Iz evangel'skoi mifologii)" (ML, 623-65).

49 Kerényi, Die Griechisch-Orientalische Romanliteratur, 151-228. See, in particular, 158-63, 173-76, 209-13. 
general, dissertation, academic degree, and dozens of others) were turned into insulting maledictions. During the time described, all "signs of mandarin servility" were condemned and liquidated. The very institution of dissertation defenses was treated as a vestige of the past [samyi institut zashchit byl sdan $v$ arkhiv].... When Zhebelev heard about my intention, he got furious. He took it as an imposition upon his very being. Indignant, he exclaimed:

"Why do you need a defense? What kind of a defense is it nowadays? Who needs it? No defenses any more! How could it come into your head! There are no defenses whatsoever! I categorically abstain!"....

Meek and mute, I stood in front of him in total depression. A distressing struggle went on inside of me.

Zhebelev was a Russian "samodur." All of a sudden, with his face twisted, he shouted:

"All right, I say yes. You have forced me, and, against my will, I say yes. But remember (with a sinister intonation)-for you. Do you hear me? I agree to it only for your sake"

We stood facing each other, each excited in a different way. Then Zhebelev lowered his voice doggedly:

"But I set several conditions. First, the Registrar's office has to send your dissertation, along with the cover letter, to my home by courier. The cover letter is to be signed by the Director and sealed. I won't accept it without a seal, remember that!"

I kept silent. Amid this destruction, Zhebelev's requirements seemed unrealizable. (3: 45-47)

Freidenberg wrote her study in a free, informal manner, and if it were not for the upheavals of the time, which made publication impossible, she, undoubtedly, would not even have considered an official defense. Under other circumstances, a study like her "Genesis of the Greek Novel" would have received an enthusiastic welcome from humanists outside of the university, whose authority was high and whose opinions were free of scholastic prejudices. Beginning in the early 1900 s, numerous informal philosophical, psychological, philological, and artistic societies, circles, and courses (kursy) complemented the governmental system of higher education in Russia. Relations between the official and these voluntarily organized institutions, although not always amicable, helped maintain a desirable balance between subversively innovative and conservative academic trends within the humanities. Despite the fact that the old St. Petersburg University did not offer seminars in Christology, and cultural anthropology and paleontology found no place in the standard programs of the Archeological Institute, the newest 
achievements in Russian and European humanities penetrated the academic establishment with little difficulty: suffice it to refer to the memoirs of M. V. Sabashnikov, who ran a publishing house famous among the Symbolists. Sabashnikov related the story of "the three friends, poets-philologists"-Tadeusz Zielinsky, Viacheslav Ivanov, and Innokentii Annenskii, who had together sworn to translate into Russian the three Greek tragedians: Ivanov - Aeschylus; Zielinsky - Sophocles; and Annenskii - Euripides. ${ }^{50}$ Zielinsky undertook this project outside of his academic teaching; the administration disapproved of his Symbolism and of his adherence to Nietzsche, but never discouraged him from embellishing his courses on Ancient drama with decadent theatrical mannerisms or utilizing his innovative ideas for "Encyclopedia of Classical Philology," a course which he taught at the university. After the October revolution Zielinsky, Karsavin, and the famous historian of the ancient world Mikhail Rostovtsev, were forced to leave Russia, and the entire system of higher education, research, and publishing was placed under strict governmental control. The rare survivors among the private publishing associations kept their doors closed to outsiders; and newcomers had no access to professional journals in the West. ${ }^{51}$ After she completed her research, Freidenberg could not hope for its publication, and an official dissertation defense remained her only alternative. But Zhebelev procrastinated with the procedure and withheld his support from his own disciple.

Freidenberg's study showed how the semantics of archaic archetypal myths of eternal rebirth became a nucleus for the morphogenesis of newer cultural forms and aesthetic categories. Her reconstruction of the binary relations between semantics and morphogenesis met with no support among the Classicists of her department, and alienated by Zhebelev, she had, for all intents and purposes, no chance to succeed in the defense of her dissertation. Fortunately (and quite contrary to Freidenberg's own expectations), her study was enthusiastically approved by a prominent linguist of her era, Nikolai Iakovlevich Marr. Without his support she probably would not have been able to remove the stumbling blocks put in her way by both the old academic establishment and the new Soviet administration.

${ }^{50}$ For the list of the courses taught at Petersburg University and at other institutions of higher education in the 1917-18 academic year, see: Nauka $v$ Rossii: Spravochnyi ezhegodnik. Dannye $k 1$ ianvaria 1918 (Petrograd, 1920).

51 M. V. Sabashnikov, Vospominaniia, ed. A. L. Panina (Moscow: Izdatel'stvo imeni Sabashnikovykh, 1995), 360. The impossibility of getting access to European academic journals-such as Archiv für Religionswissenschaft-is discussed throughout vols. 2-4 of Freidenberg's memoirs in great detail. 
Freidenberg first heard about Marr from the linguist Anatolii Genko, who was a participant in Zhebelev's seminar. Genko and other of Freidenberg's colleagues kept suggesting that she discuss her dissertation topic with Marr, yet it was not until 1923, with the entire work completed, that she ventured to do so. Marr immediately perceived the fundamental affinity between Freidenberg's ideas and his own. ${ }^{52}$ Making use of his academic authority and administrative power, Marr contacted the head of the Slavic sector of ILIaZV (the Institute of the History of Western and Eastern Literatures and Languages, of which Marr was chair) and ordered him to arrange everything for the official defense of Freidenberg's dissertation.

As Freidenberg recollected, on 14 November 1924, Marr, ignoring an established statute, appointed himself to head her dissertation committee. During the official discussion at the defense, when polemics unleashed by Freidenberg's opponents reached a peak, Marr closed the debate without ceremony, stood up, and read a resolution that he himself had written.

In it, was stated, in strong terms, that, "taking into account completely new and progressive"-I do not remember what- but, taking into account something extraordinarily good, the Dissertation Committee grants.... And before I had the chance to grasp anything, Marr who, instead of the Academic Secretary had stood up to read this out himself, quickly nodded left and right, said "no objections," and closed the assembly. (3: 104)

This unceremonious snub of academic procedures won Freidenberg the reputation of being a Marrist "groupie" and intensified the antagonism between her and the senior scholars in her field.

52 Marr's philological prescience, his talent for discriminating promising new ideas was peculiarly combined with a shortsighted, indiscriminate support of his mediocre followers and their trite views. As Freidenberg stated: "Marr had no interest in people. He lived by his theory, and a human being became visible to his sight when his/her theory was involved. He treated me marvelously, and I used to visit him, and he would read out his works for me, but as an ordinary human being I was of no interest to him whatsoever" (3: 118). 


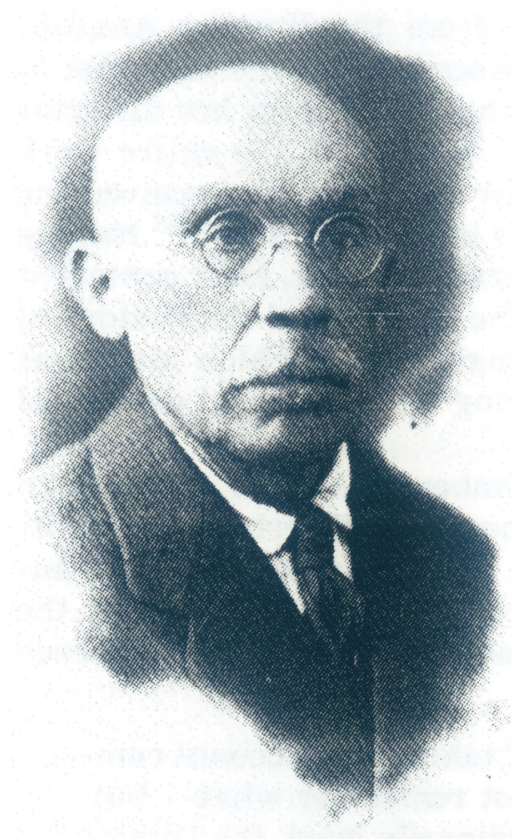

S. A. Zhebelev

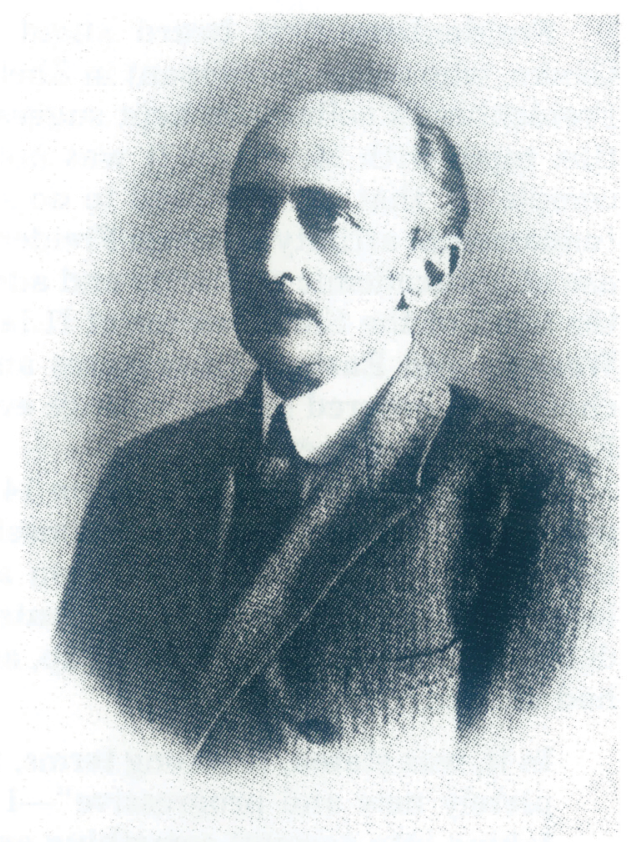

G. F. Tsereteli

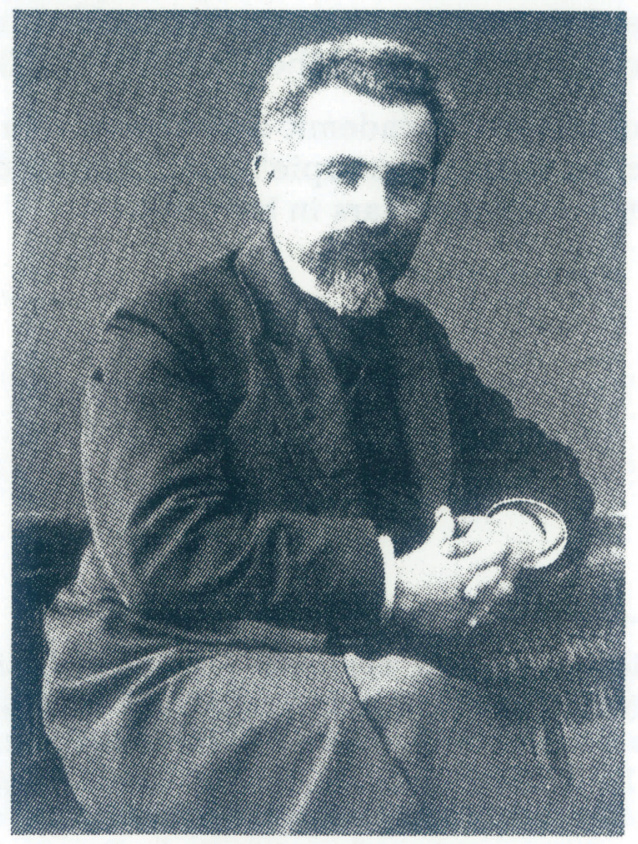

N. Ia. Marr 
Chapter 3

Studying under the Aegis of Nikolai Marr

\section{A. A Foster Child or a Stepdaughter in the Marrist Family?}

\section{day after her triumphant yet tumultuous defense of her master's thesis, Freidenberg found herself sitting, as ever, at her "school bench" in Zhebelev's seminar.}

Zhebelev was silent. My friends were eloquently silent. I was avoided, ignored by everybody.... Further events showed themselves to be very harsh on me, but I resisted them with all the strength of my spirit, my enthusiastic faith in life.... By graduation, I ceased to be a student and lost my "social status," without which people were not allowed to exist under Socialism. In order to legalize my unemployment, I had to be registered at the labor exchange. (3: 106-7)

Marr tried to help Freidenberg, but neither her newly earned academic degree nor his connections in the Council of Peoples' Commissars were powerful enough to overcome her social stated to the Peoples' Commissar of Education Anatolii Lunacharskii was an academic position secured for her at ILIaZV (3: 145-48).

Freidenberg spent ten years under Marr's aegis working for different institutions organized by him. As with Zhebelev, she recognized the significance of her apprenticeship with Marr, but she also saw clearly the irreconcilable contradictions of his personality. She admired Marr's dedication to ideas, but she realized that colleagues who did not adhere to the totality of his views and methods simply did not exist for him as scholars. Marr lived for the general cause of the idea, but for him the only lived idea was his theory. ${ }^{1}$ He supported original innovative contributions to his views, but did not tolerate any deviation from the main-

\footnotetext{
1 "Japhetic theory," or "Japhetidology," summarized Marr's understanding of the origins of human speech and thought. For a brief treatment of Marr's Japhetidology, see "Excursus on the Japhetic Theory by Nikolai Marr," 71-83.
} 
stream of his theories. In Freidenberg's case, Marr wholeheartedly supported her independent studies of the genesis of archaic mythological plots, but remained indifferent to her further genetic approaches to the composition of the genre and the dynamics of genre-plot relations, and stubbornly insisted on her adherence to his theory.

An inexperienced scholar, affected by Marr's personality, Freidenberg at first felt in a quandary, trying voluntarily to stifle in herself all of her own interests and yet feeling unable to abandon her independent way of thinking. ${ }^{2}$ In her private letters and diaries she further described the ambiguous features of Marr's personality and the ambivalent role he played in her scholarly life: a perspicacious theorist, he was not a prescient person, and he let himself be surrounded by mediocre sycophants, rather than dedicated followers. "Demanding apprenticeship from his pupils, he could not produce true disciples" (3: 134). In one of her private letters (which she copied into The Race of Life), Freidenberg stated:

I understand Marr profoundly, organically. When I listen to him, I have the excited sensation that I understand him with my entire mental organization, the entire intuition of my psyche, that I am born to be his disciple and adherent. I have never felt so free and spiritually at ease with anyone as with him.... At the same time I understand very well that as a creator he is focused only on Japhetism. He needs nothing except the blind following of his theory, and in this lies his refinement as an originator. Do not understand me in a banal way: yes, he loves blindness, finds independence annoying, and for fertilization [udobrenie] he needs obedient and ecstatic sectarianism and fanaticism. He needs only himself-himself in his pupils, himself in his source material, himself in his methods. Genius is a condenser. One can't apply philistine morals to him; I don't condemn, but praise him. But for me any revolutionism is genuine only within its own sphere. I can adhere to Japhetism and treat it passionately, if you wish, but my integrity demands from my own self independence as an individual offering to adoration. I can imagine no other forms of reverence, nor see any other way of coparticipation but the internal, the organic. I cannot be an imitator and servitor. (3: 169)

Freidenberg found it difficult to accept without reservations all of Marr's methods, but his theoretical power, the very range of his thinking did attract her. She felt proud of the fact that her first scholarly observations were acknowledged by Marr as theoretical propositions con-

2 O. Freidenberg, "Vospominaniia o N. Ia. Marre," in Vostok-Zapad. Issledovaniia, perevody, publikatsii, ed. N. Braginskaia (Moscow: Nauka, 1988), 188. 
substantial with his own views, and she never treated her contributions as a mere mechanical parcel of Marr's theoretical edifice. Through her "Recollections: On N. Ia. Marr" and through her diaries one can trace her insistent claim that her views be acknowledged independently of Marr's.

Nevertheless, the question of whether she accepted the Marrist perspective within the humanities as a solid, weighty, and self-sufficient worldview requires further consideration. A digression into Marr's career and a brief overview of his contributions to the humanities is necessary in order to understand Freidenberg's actual treatment of the main premises of Marr's theory, and where she fits among Marr's many associates: the true adherents, his "fellow-travelers" (a small group of colleagues from the university and the Academy of Sciences who escaped persecution due to Marr's protection), and the unscrupulous sycophants. $^{3}$

\section{B. Excursus into the Japhetic Theory by Nikolai Marr}

Nikolai Iakovlevich Marr (1864-1934), the son of a Scottish horticulturist and a Georgian woman, was educated at St. Petersburg University and elected an Ordinary Member of the Russian Academy of Sciences in 1912. He became known in Russia and Western Europe (Strasbourg and Berlin) for his archeological work in Ani and for his publication of early Christian manuscripts in Georgian and Armenian. ${ }^{4}$ While working with these old Armenian and Georgian scriptures, Marr had detected a common Semitic substratum in the structures of these languages. He interpreted this substratum as proof of a linguistic kinship between Iberian and proto-Semitic languages, as well as evidence of the uniformity of typological development among different ethnic cultures during

${ }^{3}$ Contemporary scholars hold different opinions regarding the degree of Freidenberg's dependence on Marr's linguistic doctrine. For example, while Nina Braginskaia in her commentary to Freidenberg's "Recollections: On N. Ia. Marr" insists on her individual scholarly interpretations of Marrism, Igor' Mikhailovich D'iakonov, author of the introductory article to the same text, and himself a former student of Marr, claims that "O. M. Freidenberg accepted all of Marr unreservedly: as a person, as a social activist, as a scholar. Even his obvious scholarly deficiencies she treated as revelations." Vostok-Zapad, 178.

${ }^{4}$ Marr's 1889 discovery of the old Georgian manuscript "Balavaar's Wisdom," authentication of its author, and classification of the text as a version of the Barlaam and Joasaph legend made his name known to the European theologians and Christologists Harnack and Krumbacher. For the publication of the texts, see Povest'o Varlaame i Ioasafe: Pamiatnik drevnerusskoi perevodnoi literatury XI-XII vekov, ed. I. N. Lebedeva (Leningrad: Nauka, 1985). For Marr's contribution to the study of the text, see 18-21. 
primeval times. From the 1880 s to the second decade of the twentieth century, Marr's research was aimed at establishing the linguistic and ethnological interconnectedness of Mediterranean (ancient Iberian, Ligurian, Pelasgian, and Hamitic) peoples and those of the protoSemitic group. His terminology was based on Biblical images and concepts: by analogy with the adjective "Semitic" (from Shem, the biblical son of Noah), Marr assigned Iberian languages to the "Japhetic" group (Japheth, the brother of Shem), and he asserted that both groups could be treated as offspring of the same forefather, Noetic protolanguage-an idea most likely borrowed from the eighteenth-century linguist James Parson. ${ }^{5}$ Later, when Marr broadened the temporal and spatial limits of his linguistic research, he chose to name his new theory "Japhetidology."

Like many scholars who combined archeological excavations with paleographic research, Marr interpreted fragments which pertained to the history of material culture through their descriptions in ancient manuscripts. By relying on data obtained from archeological excavations, he restored frescoes, graffiti, and inscriptions on temples and tombs which had been preserved as damaged fragments and isolated words. This synthesis of semantic, archeological, and paleographic approaches fit his perspective on the unity of cultural development. He envisioned the unity of cultures as a multifaceted evolutionary process which is implemented differently in various forms of communal experiences: labor-productive (meeting life's material needs, producing primitive working tools), proto-religious (collective worshipping of a fetish, participation in totemistic rituals), social (forming primeval hordes and tribes), as well as communicative (producing hand signals and articulating vocal signs of broad, barely differentiated, "syncretic" meaning). ${ }^{6}$ The syncretic component of Marr's theory was derived from Aleksandr Veselovskii, and Marr always acknowledged his indebtedness to him. ${ }^{7}$

${ }^{5}$ Kevin Moss, "Olga Mikhailovna Freidenberg: Soviet Mythologist in a Soviet Context," (Ph.D. diss., Cornell University, 1984), 29.

${ }^{6}$ Attempts at reconstructing protolanguages were always met with skepticism, which never cooled the enthusiasm of individual scholars about the discovery of a common ancestral tongue. Thus Vladimir Svitych, Aron Dolgopol'skii, and Vitaly Shevoroshkin (militant opponents of Marr's divinations) propose reconstructions of the Nostratic (from Latin noster, "our") and Dene-Caucasian languages, which were supposed to have been used sometime between 20,000 and 12,000 years ago. See Nostratic, Dene-Caucasian, Austric and Amerid: Materials from the First International Interdisciplinary Symposium on Language and Prehistory, 8-12 November, 1988, ed. Vitaly Shevoroshkin (Bochum: Universitätsverlag Dr. Norbert Brockmeyer, 1992).

${ }^{7}$ V. F. Shishmarev, "N. Ia. Marr i A. N. Veselovskii," Iazyk i myshlenie 8 (1936): 321-32; see also my "Ol'ga Freidenberg on Myth, Folklore, and Literature," 37276. 
Veselovskii emphasized evolutionary development along the temporal axis and progressed from the history of culture to historical poetics; Marr chose the tool-making experience, communal activities, and interhuman contacts as a springboard for his analyses offering historical reconstructions of the hypothetical origins of human thought and speech. Unlike Veselovskii, Marr was not particularly interested in studying the transition from folklore to literature, and he never specified which element of his multinomial formula of communal experiences played the primary role in cultural evolution.

In 1921-23 Marr revamped his Japhetidology into a peculiar interdisciplinary anthropological, linguistic, and epistemological approach"semantic paleontology," or the "paleontology of culture." It is indicative that in naming his new discipline on the origins of human speech, language, and thought Marr chose two components: semantics and paleontology. According to his idea, both of these sciences of ancient life, historical semantics and paleontology, dealt with remnants-the former of verbal, the latter of material substrata. Semantics represented that branch of language studies which dealt with semasiological change and development and traced the relationships between verbal signs (symbols, ideas) and that which they represented (material objects, things). Paleontology studied fossil remains and restored the relationships between parts (the biological or organic remnant) and wholes (the living organism). Metaphorically speaking, historical semantics could be treated as a "paleontology" of human culture, whereas paleontology could be introduced as the study of cultural morphogenesis.

A predilection for the metaphorical use of terminology served Marr both beneficially and harmfully in his reconstruction of the hypothetical protolanguage of all humans. It kept him open to new and daring ideas (hence his enthusiasm about Freidenberg's university work and his willingness to attract academic attention to her study), but it also negatively affected the precision of his Japhetidological assertions. ${ }^{8}$ For instance, Marr's search for a common semantic substratum led him to use the evidence of fossil jaws as a starting point in his reconstructions of the glottogonic process; but having arrived at certain conclusions about glottogony and glottochronology, he was too quick to transfer them onto

\footnotetext{
${ }^{8}$ According to V. M. Alpatov, who consulted V. I. Abaev, Viach. Vs. Ivanov, and S. A. Starostin ("the three acknowledged comparativists of three different generations") about the validity of Marr's Japhetidology, contemporary linguists do not accept the notion of the Japhetic group of languages, yet some theorists acknowledge the power of Marr's intuition and believe that his hypothetical assertions are to be reconsidered as valuable suggestions. See V. M. Alpatov, Istoriia odnogo mifa. Marr i marrizm (Moscow: Nauka, 1991), 25.
} 
contemporary nonalphabetized languages. ${ }^{9}$ In his analyses of the history of nonalphabetized languages, Marr did not take into account isogloss demarcations, and merely speculated about the ways human collectives learned to systematize and communicate discrete experiences. ${ }^{10}$ While discussing cultural survivals he did not distinguish between linguistic and extralinguistic data. From the aggregate meaning obtained from cuneiform and hieroglyphics, Marr moved arbitrarily in two opposite directions: he inductively hypothesized the semasiological and lexical archetypes, and then deducted from the formulae obtained concrete meanings for contemporary lexemes (whence his groundless conclusions on the affinities of modern Ossetic and protohistoric Japhetic languages). ${ }^{11}$

In his explanation of evolutionary processes, Marr proceeded from the stage-structure dichotomy. In the paleontology of culture, "stage" (stadiia) was not exactly synonymous with "epoch" because, Marr insisted, every stage in cultural development was defined by interdependent correlations of different types of collective experiences. At each stage of evolution, language, understood as the primary tool of social contact, provided collectives with their fundamental means of both forming and formulating an aggregate vision of the world and of man's place in the universe. The semantic structures of language, while correlated with a particular stage of cultural development, also preserved cultural survivals of earlier periods. As Marr believed, the polysemantic properties of the primeval lexicon derived in an autochthonal way from communicative signs and signals of more archaic stages of development. In her summary of Marr's Japhetic theory, Katerina Clark writes: "In canonical Marr, languages are said to have evolved not so much when tribes migrated or when one language group borrowed from another, but rather in a process akin to hybridization; when two tribes or other

\footnotetext{
${ }^{9}$ Glottogony, a discipline dealing with the origins of human speech, and glottochronology, a method of linguistic divination estimating the dates when the protolanguage appeared and the branches of language families separated from it, were used by Marr as linguistic underpinnings for his semantic paleontology of culture.

${ }^{10}$ See D. I. Edel'man and G. A. Klimov, "Iz istorii odnoi drevneperedneaziatskoi leksicheskoi izoglossy," in Irano-afraziiskie iazykovye kontakty, ed. G. Sh. Sharbatov (Moscow: Nauka, 1987), 162-67. Edel'man and Klimov juxtapose Marr's imprecise restoration of Japhetic names indicating trees and plants and I. M. Steblin-Kamenskii's wholly reliable analysis of the same concept.

${ }^{11}$ N. Ia. Marr, “Ossetica-Japhetica,” Izvestiia Akademii nauk (1918), 2071-73.
} 
language groups were thrown together by common economic need or practice." 12

At the archaic stage, each single instance of communication was not yet sensed as an individual sign, but remained closely associated with the totality of syncretic meanings. Marr remained evasive about the defining characteristics of a "stage." At one point, his "stage" characterized collective practices in production; in another instance, it pointed to cognitive thinking and the reflection of reality; in a third situation, the stage was linked to the societal organization of primordial hordes and thus was defined by the enactments and practices which were meant to protect the tribe from destruction. According to Marr's theory, the cognitive processes and communicative practices of human beings evolved through successive stages of development. To illustrate the lack of precision in his definition of the developmental stage, Lawrence Thomas, author of the most exhaustive critical study of Marr's linguistics, quotes from On The Japhetic Theory :

There was an epoch [stage-N. P.] of ethnic word creation; preceding it was an epoch of cosmic word creation when there were so few oral words (which concretely denoted, in live images, the perceived cosmic forces) that they expressed a multitude of entities-gradually perceived in their independent existence. In contrast to the association of ideas (with which we are accustomed from historical epochs), there took place a dissociation of ideas-the extraction, from a single pan-perceptible image, of its partial aspects of mythological transformations which had already separated out in consciousness. ${ }^{13}$

12 Katerina Clark, Petersburg: Crucible of Cultural Revolution (Cambridge: Harvard University Press, 1995), 213-14. Clark's chapter "Nikolai Marr" (21223) is, in my mind, the most original, challenging, and provocative summary of his linguistic ideas.

13 Lawrence L. Thomas, The Linguistic Theories of N. Ja. Marr. University of California Publications in Linguistics, no. 14 (Berkeley: University of California Press, 1957), 74. Thomas quotes from Marr's "Ob iafeticheskoi teorii," Izbrannye raboty (Moscow-Leningrad, AN SSSR, 1929), 3: 32. No comprehensive revision of Marr's theories has been produced since the work of Thomas, who as a linguist conducted his entire study in isolation from the history of ideas. Recent analysis of "ideological perversions" in the Soviet humanities, offered by René L'Hermitte (Marr, marrisme, marristes: Science et perversion idéologique. Une page de l'histoire de la linguistique sovietique [Paris: Institut d'études slaves, 1987]), does not change the standard opinion that, except for the early writings, in which Marr studied the history of Caucasian languages, his entire "theory" was but a purely anecdotal neglect of scientific methods of research and a misleading trick: "une désinvolture accablante dans le maniement des 'preuves'" (95). Rendered in far cruder language, this evaluation was pronounced by Stalin 
The passage from Marr allows for many discrete interpretations: it is compatible with Veselovskii's syncretic approach and Lévy-Bruhl's explanation of "how Natives think"; one can interpolate into it some of Cassirer's statements, as well as suggest interpretations borrowed from the dialectical materialism of Marx and Engels, and from the empiriocriticism of Lunacharskii and Bogdanov. ${ }^{14}$

Beginning in the mid-1920s, an emphasis on Marxist monistic underpinnings grew stronger in Marr's theories. Through paleontological analysis of the common glottogonic process, he discovered the most archaic elements in human speech and was able to reduce the variety of clearly distinguishable ethnic elements from twelve to seven, then to five, and eventually to four elements: SAL, BER, YON, ROSH. Marr treated the "four elements" as a uniform reflection of the single creative process in all languages. "In its entire volume, language is the creation of a human collective, a reflection not only of its thinking in semantics, but of its social order, as well as of its economics in technical and social

in 1950. Alpatov, in Istoriia odnogo mifa (191-214), goes into greater depth in restoring the peripeteia of the linguistic discussion unleashed by Stalin. He provides ample bibliographical and documentary sources concerning the history of Marr's "New Teaching on Languages," but he does not provide any critical overview of the contents of this doctrine. Finally, M. V. Gorbanevskii in $V$ nachale bylo Slovo ... Maloizvestnye stranitsy istorii sovetskoi lingvistiki (Moscow: Universitet druzhby narodov, 1991), 46-62, expresses more interest in Marr's logogenesis and in the Marrist theory of stages.

${ }^{14}$ Aileen Kelly, "Empiriocriticism: A Bolshevik Philosophy?" Cahiers du Monde russe et sovietique 30: 1 (1981): 89-118. Kelly treats Bogdanov's empiriomonism as a nontraditional Marxist epistemological creed. Her observation that the supporters of empiriomonism "started out from a view of the world as a complex of sensations, but argued that, as the latter differed from individual to individual, the reality was to be found only in their 'common multiple," may suggest an analogy with Marr's theories. In both Marrism and Empiriomonism, the entire world, as "a complex of sensations," "constitutes the subject-matter of science, which endows it with simplifying symbols, namely, laws and concepts. True reality lies in these "empirical symbols" (Kelly, "Empiriocriticism," 115). During lecture tours in Baku, Marr and Meshchaninov were asked about epistemological affinities between Japhetidology and Empiriomonism, and both abstained from unambiguous answers, whereas Valerian Aptekar', Marr's "political hand," stated vociferously that the New Teaching on Language (novoe uchenie o iazyke) of Marr has no common ground with the "petit-bourgeois" Empiriomonism. See V. B. Aptekar', N. Ia. Marr i novoe ucheniie o iazyke (Moscow: Gosudarstvennoe sotsial'no-ekonomicheskoe izdatel'stvo, 1934), 118-20; see also I. Meshchaninov, "Osnovnye nachala iafetidologii," Izvestiia obshchestva obsledovaniia $i$ izucheniia Azerbaidzhana 1 (1926): 63-76; N. Marr, Iafeticheskaia teoriia. Obshchii ocherk ucheniia o iazyke (Baku: AzGIZ, 1928). 
structures." 15 Marr maintained that the dynamics of linguistic evolution are, eventually, defined by the dynamics of social and economic class relations, and he delivered this new theory to his audience through a plenitude of articles and brochures that scarcely differed one from another in their propositions and frequently carried identical titles. His typology of linguistic development attacked comparative ethnolinguistics and the notion of national languages. Marr insisted that his revised model of language development corresponded to a schematic view of "economic-cum-social" cultural development. ${ }^{16}$ The latter mental abstraction, in its turn, demonstrated that the primeval practical experience of developing productive forces influences the development of speech, language, and culture. The use of new technical skills in material life promotes a further development of language resulting in the "hybridization of languages." These hybrid forms are brought about by a more advanced stage of cultural development and represent a more complicated structure of social contacts. Within those hybrid language structures, however, survivals of the earlier stages of communal experience are preserved. In other words, the history of speech awareness reflects the evolution of socio-economic processes and class consciousness. From this generalization Marr proceeded to additional abstractions: "There is no ethnic, all-national language, but there is a language of a class. Languages of one and the same class in different countries, while retaining the identity of social structure, reveal a greater typological kinship between each other, than the languages of different classes in the same country, of the same nationality."

Proceeding from semantic paleontology to the "paleontology of culture," Marr complemented the "stage-structure" binary relation with the dialectical opposition of "survival" to "link" (perezhivanie-uviazka). To illustrate his understanding of cultural evolution, Marr used the following example:

An 'axe', a metal tool, represents a functionally inherited name for a stone 'axe'; 'stone,' which was in its turn a designation for a 'hand', transferred its denomination (naimenovanie) to objects that took upon themselves the functions of a 'hand'. As all these objects derive from a 'hand', moving along the lines of material

15 N. Marr, "Pochemu tak trudno stat' lingvistom-teoretikom," in Voprosy metodologii $i$ teorii iazyka $i$ literatury: Iazykovedenie $i$ materializm (Leningrad: Priboi, 1929), 47.

${ }^{16}$ Clark, Petersburg, 214. The reference is to N. Marr's article "Ob iafeticheskoi teorii," Iafeticheskaia teoriia (Moscow: VNAV, 1924), 4.

17 Marr, "Ob iafeticheskoi teorii," 33. 
culture leaves one with the words which indicated 'knife', 'sword', 'dagger', etc., etc. ${ }^{18}$

During the last years of his career, Marr arrived at the formulation that "words" were to be understood as "social values brought about by the relations of production in the process of their dialectical development." 19

With all of his radicalism, Marr did not necessarily aim to dispute Western science with his theories. On the contrary, as late as 1929, he had the temerity to refer with respect to his former colleague, the émigré scholar Mikhail Rostovtsev, and to acknowledge the achievements of Henri Bergson and Lévy-Bruhl. ${ }^{20}$ As the editor-in-chief of the series Questions of Methodology and Theory of Language and Literature: Language Studies and Materialism, he solicited S. M. Dobrogaev's paper "The Phoneme as a Physiological and Social Phenomenon," and he published Dobrogaev's critical review of Saussure in the same volume where he placed his own programmatic article, "Why It Is So Difficult to Become a Theoretical Linguist." 21

What is most important, however, is that Marr, both as a social activist during the Stalinist era, and, at the same time, a venerator of pure ideas, used the paleontology of culture as a shelter for many scholars who did not share his materialistic doctrine. Like Noah, he took into his Japhetidological ark specimens both "clean and unclean," and rather than seven months and seventeen days (as in the Bible), for seventeen years (from 1917 to the day of his death in 1934), the Japhetidological ark floated relatively safely over the troubled sea of Marxist ideology. ${ }^{22}$

Marr remained loyal to his colleagues from the old Academy of Sciences, but nonetheless felt truly exalted that during his lifetime his theory was pompously announced as nothing less than the "New Teaching on Language" (novoe uchenie o iazyke). This ascension of the founder of the New Teaching to Stalin's Olympian Pantheon, and his subsequent katabatic descent to the underworld and oblivion have been discussed recently as a manifestation of Soviet totalitarian myths.

${ }^{18}$ Ibid., 41.

${ }^{19}$ N. Marr, Iazyk i myshlenie (Moscow: Sotsekgiz, 1931), 19.

${ }^{20}$ Marr, "Pochemu tak trudno stat' lingvistom-teoretikom," 19-23.

${ }^{21}$ S. M. Dobrogaev, "Fonema kak fiziologicheskoe i sotsial'noe iavlenie," op. cit., $57-63$.

22 According to V. A. Mikhankova, Marr's revision of Japhetidology in light of Marxism was catalyzed by his trips to Europe in 1920-21 and 1922-23. See her Nikolai Iakovlevich Marr: Ocherk ego zhizni i nauchnoi deiatel'nosti (MoscowLeningrad: AN SSSR, 1949), 311-12, 476-79. 
Analogues have been proposed in the modern myths of the State (Katerina Clark), in the myths of Genesis, with Stalin as the embodiment of the Holy Spirit and his Soviet heroes as the prophets (V. Alpatov), and in Trofim Lysenko's Genetics and Ivan Michurin's Biology (Katerina Clark, Kevin Moss). ${ }^{23}$

Freidenberg also drew parallels between Marrism and primeval myth structures. In The Race of Life, she described Marr's expulsion from Stalin's Olympus (1950) as a desecration of the old totem:

Stalin, this prestidigitator, this circus magician, assumed the role of a humble, ordinary reader defending the freedom of personal opinion. Never before had he done anything so insidious.... A bomb exploded! Stalin annihilated Marr, a scholar whom he himself had conjured up and cherished. A coward and traitor, he shifted all responsibility from himself to the executors of his will, and he did it at the moment when the Central Committee of the Party had compulsorily turned the teachings of Marr into irrefutable dogma. Just before the articles appeared, innocent people were persecuted and killed as never before for criticizing Marr, and that was done according to the tyrant's prescript. This whole thing was a scandalous and revolting falsehood. Now it appeared that neither the government, nor Stalin, nor the Party had founded academies and institutes for Marr, awarded him the highest orders, and arranged pompous ceremonies in his honor. If it wasn't they, who else was it-you, I, he, she-ordinary people? It wasn't Stalin who wrote to Marr and encouraged him, even though, before my very eyes, Marr used to receive felicitations from the tyrant (most likely destroyed by now by an invisible hand). (15: 133-34)

The dichotomous dynamics of consecration and desecration, which Freidenberg emphatically underscores, helps relate the aberrations in the development of Marrist human sciences to the mechanics of modern political and social myth-making. Serious reservations about the validity of Marr's linguistics were originally expressed by such prominent

\footnotetext{
${ }^{23}$ Katerina Clark, The Soviet Novel: History as Ritual (Chicago: Chicago University Press, 1981), 114; in Petersburg: Crucible of Revolution, 200-23, the mythological component of Marr's theory is defined as "Promethean linguistics," and further similarities between Marrism and the Stalinist botanists Michurin and Lysenko, who worked on genetic issues, are proposed (214). See also Alpatov, Istoriia odnogo mifa, 32-111; Moss, "Olga Mikhailovna Freidenberg," 38-40.
} 
theorists of hypothetical archaic and modern spoken languages as Nikolai Trubetskoi and Lawrence Thomas. ${ }^{24}$

The more determined Marr was in his attempts to restore a common semantic substratum in isolation from phonology and the history of languages, the more unrelenting were Trubetskoi and Thomas in their objections to Marr's theories. To outline briefly their disagreements with Marr, it suffices to quote a paragraph from Thomas summarizing the traits he found inadmissible for sound linguistic work. According to Thomas, Marr's working method showed: “(1) a tendency to ignore the history of a language; (2) a tendency not to specify, and even to ignore, temporal restrictions in the framing of sound laws; (3) a penchant (which eventually grew to the point of ludicrousness) for assigning a language to one family or another on the basis of a single morphological element; (4) a complete rejection of the possibility of borrowing." ${ }^{25}$ This impressive list could easily be complemented by a fifth point: Marr's tendency to present consubstantial concepts as identical and to obliterate the distinctions between philosophical semantics and linguistics, as well as between hermeneutics and etymology.

Trubetskoi's and Thomas's sound objections to Marr's theories raise several questions. Why did so many talented historians, anthropologists, folklorists, and linguists accept Marr's new creed? And how did it happen that their close association with Marrism largely helped augment the value of their contributions to linguistics rather than impede the development of new ideas? One example is Ivan Meshchaninov's syntactic study of the "ergative construction" (ways of expressing a relation to an object in different languages), which he believed to be a development of Marr's teachings on semantics. ${ }^{26}$ Moreover, scholars absolutely untainted by opportunism worked under Marr's auspices and found the basic

${ }^{24}$ N. Trubetskoi, "Lateral'nye soglasnye v severokavkazskikh iazykakh," in his Izbrannye trudy po filologii (Moscow: Progress, 1987), 233-47, first published as "Les consonnes latérales des langues Caucasiques-Septentroinales," Bulletin de la Société de Linguistique, vol. 23 (72): 1922, 184-204. Lawrence Thomas, The Linguistic Theories of N. Ia. Marr, 22.

25 Thomas, Linguistic Theories, 25.

26 In "Problema stadial'nosti v razvitii iazyka" (1947) Meshchaninov juxtaposes two formal-typological tendencies in linguistics: evolutionary and stageoriented. The evolutionary approach traces the progression "from amorphous to agglutinative, then to inflective, and, finally, to analytical" languages and formulates its conclusions in terms of historical linguistics. The stage-oriented approach, developed by the followers of Marr, takes into consideration structural correlations in expressing the subject's relational attitude towards the object and distinguishes between "amorphous, possessive, ergative, and nominative constructions." See I. Meshchaninov, Problemy razvitiia iazyka (Leningrad: Nauka, 1975), 294-95, 293-312. 
premises of his theories stimulating for their own studies. Obviously, the notorious "cult of personality" (Marr's, or in the wider context, Stalin's) cannot explain their infatuation with Marrism, for identifying this behavior as cultic merely rephrases the statement about modern mythmaking. Perhaps one should approach Marr's New Teaching not as a linguistic theory, but as a "philosophy of language." ${ }^{27}$ Marr's teachings should be considered as a component of the epistemological hypothesizing about the origins of human language (glottogony) and the linguistic acquisition of consciousness (logogenesis). From this viewpoint, his ideas, while not relieved of all their contradictions, do at least become comprehensible in their very contradictoriness.

As a contribution to the history of ideas, a number of analogues to Marr's teachings are readily found from the time of Democritus (with whom Marr would "share common ground" by accepting the "four elements") to that of Karl Jung (archetype theory, which also takes its origin in Democritus), Lévy-Bruhl (the statement on prelogical thinking revamped by Marr), and Ernst Cassirer (whose Language and Myth and Mythical Thought, the second volume of The Philosophy of Symbolic Forms, were brought to Marr's attention and adapted for the needs of his theory by I. G. Frank-Kamenetskii in 1929). ${ }^{28}$ Among the Marxist philosophers, Abram Deborin discussed the interdependency between the pronominal forms I, YOU, HE and the time-spatial categories HERE (on the spot, the situation of presence), THERE (at any other place distanced spatially or temporally from the present location), and OVER THERE (situated at a more distant point). Although Deborin's goal was to link Marr's New Teaching to Marxist dialectics, he made free use of Cassirer's Philosophy of Symbolic Forms, and he referred to neo-Kantian philosophy and the writings of Lévy-Bruhl in a positive context. ${ }^{29}$

Within this epistemological framework, the most internally contradictory assertions of Marr's theory, such as his postulation of the autochtonal development of languages, while retaining the theory of

${ }^{27}$ For those familiar with the works of the Bakhtin Circle, this definition brings to mind the subtitle of V. N. Voloshinov's Marxism and the Philosophy of Language (1929), which was published under the aegis of Marr's Japhetic Institute and included several references to Marr. Freidenberg, who met Voloshinov in 1930, stated unequivocally that this work was "written for him by Blokhin" [sic!] (4: 226). See also my "Funny Things are Happening on the Way to the Bakhtin Forum," Kennan Institute for Advanced Russian Studies Occasional Papers, no. 231 (1989): 25-27.

${ }^{28}$ I. G. Frank-Kamenetskii, "Pervobytnoe myshlenie v svete iafeticheskoi teorii i filosofii," Iazyk i literatura 3 (1929): 70-155.

${ }^{29}$ A. M. Deborin, "Novoe uchenie o iazyke i dialekticheskii materializm," in Akademiia Nauk SSSR XLV Akademiku N. Ia. Marru (Moscow-Leningrad: AN SSSR, 1935), 21-73. 
multiple origins, lend themselves to interpretation and reveal underlying features of Romantic theories of cognition. ${ }^{30}$ Moreover, the typological compatibility between the views of Marr, Vico, Dante, and Herder begins to make sense. Like Vico in Scienza nuova, Marr dreamt of a theory of cognition which would trace the verbal communication of mankind through different stages of social, cultural, and anthropological development back to an archetypal and common pre-form-to the point at which, as in Vico, the physical world ("il mondo della natura") and the world of mankind ("il mondo delle nazioni") were molded into an indivisible integrity. ${ }^{31}$ Like Dante in De vulgari eloquentia, Marr associated the common prehistoric protolanguage with the early human need to name God (or totem, in Marr) "either as an appeal or as a response." Rather than restore the lexical pre-form of this primary "word," Marr relied on its "archetypal meaning," and from there inferred that "Perhaps, in essence, 'the word' was for a tribe its totem, its God." ${ }^{32}$

Marr included modern languages of different groups into his Japhetidology, but he did not analyze contemporary lexicons or grammars. He was concerned with the pre-historical cognitive and communicative substratum at the stage when the very act of speaking rendered the self-identification of a tribe, when speech fulfilled the function of "ethnogeny." Marr coined the term "ethnonym" for this purpose.

A tribe had its own verb meaning 'to speak' and coinciding in sound with its own tribal name. That is to say, the uttered term for 'speaking, speech' indicated also the tribe's totem and was its ethnonym ... its sacred thing and its symbol. ${ }^{33}$

According to Marr, all speaking ethnic groups, peoples, and nations of the contemporary era shared common prehistorical stages of cognitive development. The identical features of peoples' mental development were fixed in their communicative practices, or proto-languages.

\footnotetext{
${ }^{30}$ Katerina Clark also believes that Marr's theories "can be seen as part of a European theory dating from at least the German Romantics, who believed that language is thinking"; see her Petersburg: Crucible of Revolution, 220.

31 For a comprehensive discussion of Vico's ideas, see Erich Auerbach, "Vico and Aesthetic Historism," in his Scenes from the Drama of European Literature (Gloucester, MA: Peter Smith, 1973), 189-90. My suggestion of an analogy with Dante's treatise is based on Dante, "O narodnom krasnorechii," in his Malye proizvedeniia (Moscow: Nauka, 1968), 272-76, and N. Marr, "Nazvanie etrusskogo boga smerti Kalu i terminy pisat', pet', chert, poet i slepets," Izvestiia Rossiiskoi Akademii Nauk 18 (1924): 184-90.

32 N. Marr, "Iz poezdki k evropeiskim iafetidam," Iafeticheskii sbornik 3 (1925): 50.

33 Ibid., 50-51.
} 
Focused primarily on his theory of logogenesis, Marr remained rather indifferent to the enthusiasm expressed about the possibility of reunifying all the existing languages of the world in a single international lexicon-a Marxist utopia advocated by his political allies from the Iazykofront. But he never argued with the Iazykofront extremists who insisted on the political correctness of their interpretation of the New Teaching. At the same time Marr certainly realized that his association with this internationalist linguistic utopia secured him an advantageous position in Soviet academia. ${ }^{34}$ One can see why the rise and the fall of N. Ia. Marr, the creator of the New Teaching on Language, followed all the crucial turns in Stalin's internal and global politics. For so long as the doctrine of the victory of Socialism in an isolated country (a universal and international phenomenon that develops autochthonously) held sway, Marr's ambivalent combination of autochthonal genesis and the multiple origins of languages was acceptable. But when the Communist bloc was built after World War II, all notions of multinational forms of communicating ideas were eradicated. ${ }^{35}$

\section{Meeting I. G. Frank-Kamenetskii, Life-Long Friend and Like-Minded Thinker}

To return to Freidenberg, although Marr obtained for her an academic position at ILIaZV, it took the employment office of this institution almost two years (from 25 February 1924 to 18 December 1925) to process Freidenberg's documents and to pay her the first monthly salary of twenty-four rubles and thirty-three kopecks $(3: 152-57$.) Hurt by these bureaucratic procrastinations, Freidenberg remained alienated from her colleagues at ILIaZV, and she entered into her diaries the following caustic appraisal of this institution: "Here governed terrible lawlessness and crude fleecing of the state and of the people, who were sharply di-

\footnotetext{
${ }^{34}$ Iazykofront played the same role in language studies as Proletkult in literature: the primary task of the organization was to translate Marr's theories into the language of Marxist ideological doctrine On members of Iazykofront and their methods of tailoring the New Teaching on Language in agreement with the patterns of Stalinist ideology, see Alpatov, Istoriia odnogo mifa, 79-109.

35 In a different connection, in Petersburg: Crucible of Revolution (278-79) Katerina Clark draws into the discussion Stalin's article "O nekotorykh voprosakh istorii bol'shevizma. Pis'mo k redaktsii zhurnala Proletarskaia revoliutsiia" (Proletarskaia revoliutsiia, no. 6 [1931]: 3-12). "In this essay," Clark states, "Stalin ... took the anti-Western trend and undermined the theory of the "two Berlins'; he drew a qualitative distinction between German Communists ... and Bolsheviks, favoring the latter." From approximately this time, Clark suggests, "it was not enough to be leftist or even Communist to be acceptable in Soviet Russia."
} 
vided into wolves and sheep; it was, if you wish, a patriarchal situation of doing-for-nothing, cheating, and primitive arbitrariness" (3: 158). Therefore, it was with great relief that she welcomed Marr's 1926 invitation for her to join his Institute of Language and Thought (Institut Iazyka i Myshleniia, IIaM), also known as the Japhetic Institute. ${ }^{36}$ There Freidenberg joined the "mythic section"-a group composed of scholars with different specializations and rather vaguely united by acceptance of Marr's Japhetidological methods. Among the "mythologists," Freidenberg's colleagues were Tat'iana Sergeevna Passek, a linguist and an expert on Chuvash oral lore; Vasilii Komarovich, an expert on Old Russian literature and religious folklore; Vasilii Struve, who studied the time and space measurements and calendar systems of the ancient Babylonians; Vladimir Shishmarev, a well known Medieval and Renaissance scholar; and Izrail' Grigor'evich Frank-Kamenetskii, an expert in Hebraistics, Egyptology, and Semitic religious lore, who as a person and a scholar would play a very important role in Freidenberg's life. Freidenberg did not like Ivan Ivanovich Meshchaninov, a linguist who served as the Academic Secretary of the sector, yet by and large she developed a warm familial disposition toward the members of the group. During the following two years the "mythologists" were moved from IIaM to IlIaZV, and new philologists and historians joined the small collective-Moisei Al'tman, a Classicist who had studied under Viacheslav Ivanov in Baku, and Boris Bogaevskii and Raisa Shmidt from Perm', both historians who studied the relations of production in agriculture, industry, and the economics of ancient times. ${ }^{37}$

Until 18 June 1927, the Soviet Academy of Sciences operated under the old eighteenth-century statute, which among other privileges, allowed its ordinary members uncensored exchange with foreign colleagues and a free apartment in an Academy building. After the Revolution, while on business trips to Leipzig, Berlin, Paris, and Bilbao, Marr openly contacted European Christologists and émigré scholars from

${ }^{36}$ IIaM was founded as the result of reorganization of the Institute of Japhetidological Studies (generally known as the Japhetic Institute) and was located next door to N. Marr's apartment in an Academy building.

37 Beginning in the early 1900s, Azerbaidzhan State University in Baku and Perm' University in the Urals were sponsored by St. Petersburg University. The head of the History department in Perm', Nikolai Petrovich Ottokar, maintained professional contacts with Zhebelev, Grevs, and Rostovtsev in Petersburg. Ottokar studied medieval guilds, legislatures, and municipalities in France and Italy; and Boris Bogaevskii owed the knowledge of the cultural history and urban structures of ancient and medieval cities to his apprenticeship under Ottokar. During 1922-24, Marr and Meshchaninov lectured on Japhetidology at the University in Baku, where Al'tman was a student; in $1925 \mathrm{Al}$ 'tman applied to Marr's ILIaZV for graduate study. 
Russia, but it never occurred to him that in all of these academic settings, as well as in his own IIaM apartment in Leningrad, he remained under the surveillance of secret informers. Freidenberg had a clearer understanding of who these people surrounding Marr were. She did not feel comfortable with the paternalistic, sycophantic, bureaucratic, and politically oppressive working conditions of those scholars; but she realized that "it was still the Chronian age of liberty" (a later remark in The Race of Life, 2: 2).

At IlIaZV and IIaM, scholars were somehow allowed to provide individual interpretations of Marrism, although a unanimous dedication to Japhetidology was required. This license resulted from the peculiar combination of arbitrariness and insightfulness in Marr's own theoretical views. Working under Marr's aegis, Freidenberg published twelve of her major papers, delivered several talks at various panels and roundtable discussions, and prepared for publication the only monograph which was published during her life time, The Poetics of Plot and Genre. Freidenberg believed that she, Frank-Kamenetskii, and Marr formed a group of genuinely like-minded thinkers: "The rarest ideas, not yet uttered by anybody, slipped at the same time, in the same city, from the lips of three people-three humans of different lives, fates, dispositions, and ethnic cultures. Marr's Caucasian nature was clearly sensed; FrankKamenetskii was a typical European, a German scholar; I was of Russian culture." As she wrote about Frank-Kamenetskii:

Comparing him to myself, I clearly sensed the difference between us: he possessed the heights of scientific thinking, the sum of academic culture in the deepest sense; he was endowed with a completeness of knowledge, with refinement of thought, argumentation, and a talent for scientific discourse-but I was more lavishly endowed with intuition, albeit rough and crossgrained. (3: 83-84)

Frank-Kamenetskii, at that time already the author of several books on ancient Semitic religious concepts, became familiar with Freidenberg's dissertation in June 1924, when he himself was working on an article "Water and Fire in Biblical Poetry." ${ }^{38}$ He found that Freiden-

${ }^{38}$ I. Frank-Kamenetskii, Pamiatniki egipetskoi religii (Moscow: Skoropech. Levinson, 1918); "Voda i ogon' v bibleiskoi poezii," Iafeticheskii sbornik 3 (1925): 127-65. In late 1925 Frank-Kamenetskii was proofreading the manuscript of his book Proroki-chudotvortsy. O mestnom proiskhozhdenii mifa o Khriste (Leningrad: Seiatel', 1925), and included into the definitive text of the book (p. 81) a reference to the chapter from Freidenberg's dissertation in which she discussed the redistribution of a cosmic substratum of divine nature among the heroes of different mythologies, and the functions of this cosmogonic substance in newer topical settings. 
berg's ideas on the common morphogenesis of different genre categories agreed with his own. Like Freidenberg, Frank-Kamenetskii used texts of the canonical scriptures, pseudepigrapha (writings that were alleged to have been composed in biblical times, but were never accepted as canonical), and Christian apocrypha for his study ProphetsThaumaturges: Towards a Localization of the Origins of the Myth of Christ. Working mainly with the pseudepigrapha and ancient Egyptian sources, he laid out the proofs for an autochthonal localization of myths relating to salvation, resurrection, and the risen pagan deities; and he then discussed the typological affinities in the composition and plot structures of the various scriptural versions of these salvific efforts made by redeemers. Like Marr, he recognized in typological affinities evidence of identical stages in the evolution of social consciousness (rather than cultural borrowings from one ethnic group to another or multiple attempts to relate a tale about a real historical personality). With great precision Frank-Kamenetskii traced the dialectical relations between an invariable autochthonal content and the variety of forms in which this diffuse substratum became manifest in individual ethnic cultures. Like Freidenberg, who studied Greek sources and early Christian apocrypha, Frank-Kamenetskii used sources from Semitic religious lore to trace the process of resemanticization, which transposes the common narrative substratum into individual plots and genres. His work thus revealed dialectical relations between homogeneity and heterogeneity. It is no surprise, therefore, that when Freidenberg became familiar with FrankKamenetskii's book, she noted: "Everything he was talking about repeated me to such an extent that it was of almost no interest to me. I studied Greece and looked for connections and explanations to the Bible; he studied the Bible, and looked for connections and explanations to Greece"(3: 83). Indeed, while Freidenberg asserted morphological identities between three types of plots-the travel adventures experienced by the heroes of Greek erotic novels, the journeys of the Apostles in Christian apocrypha, and the life/death metamorphoses of divine pagan life-givers-Frank-Kamenetskii recognized in the mythological prototypes of biblical thaumaturges the resemanticization of features characterizing "the series of divinities whose nature was identical to Yahweh." ${ }^{39}$ In a lengthy letter to Freidenberg he enthusiastically acknowledged the principal affinities between the conclusions they had drawn from the examination of different sources. ${ }^{40}$ In Freidenberg's study of ancient Greek myths he found parallels to his treatment of the legends of Elijah, Elisha, Moses, and Joshua the son of Nun. As he wrote about these figures, "In the mythological prototype of the heroes, we

39 Frank-Kamenetskii, Proroki-chudotvortsy, 73.

${ }^{40}$ Freidenberg copied this letter of 26 June 1924 in her Race of Life, 3: 93-97. 
discovered, along with the aqueous character of the deity, features which pointed to his solar nature." These cosmic features, FrankKamenetskii insisted, represented the cultural survival of archaic experience, the integral meaning of which could be summarized by the threefold formula: "water-light-fire." 41

In his letter Frank-Kamenetskii also argued with Freidenberg about her conjecture that the name of the hero "transcribes" and preserves in a condensed form the acausal plot structure of the archaic myth. Studying her Thecla apocrypha and moving backward and forward along the chronological axis, Freidenberg discovered in the heroes' names cultural survivals of old mythological semantics and suggested that a recognizable morphological component of the private name (a remnant, an isolated part) does actually represent the complete, yet extinguished whole. Thus Thecla (Dekla, a palm tree in Hebrew) is to be understood as a cultural survival of the palm in Isis' hand and provides a symbol for salvation and resurrection; the female name Falconilla (a deceased daughter of the queen Tryphaena, Thecla's foster-mother) would lead to 'falcon', a pictorial emblem of Isis and also a symbol of immortality. A "transcription" of the mythological plot-structure then, Freidenberg argued, could be seen in Thecla's prayer to God asking the Son of the Almighty to grant to the queen Tryphaena "according to her wish, that her daughter Falconilla may live forever." 42 Frank-Kamenetskii found this identification of etymology with hermeneutics in Freidenberg's work rather far-fetched. He suggested that the biographies and adventures of mythological heroes, whose names were etymologically related to the archetypal elemental forces (such as 'Moses'- "drawn out of the water"), were causally determined and originated from daily life and historical surroundings. Conversely, the thaumaturge's functions throughout the plots of these legends incorporated a series of poetic synonyms for the mythical element ('water', in the case of Moses). As a cultural survival, the thaumaturge's function maintained its connection to archaic stages of consciousness, whose diffuse forms rendered dichotomies as semantic identities. $^{43}$

Still a novice in academic discussions, Freidenberg interpreted Frank-Kamenetskii's friendly observations as a polemical thrust and parried his criticism in "Thamyris" (1924-25, published 1926). This paper extended her study of "The Acts of Paul and Thecla." Thecla's

\footnotetext{
41 Frank-Kamenetskii, Proroki-chudotvortsy, 72-73.

42 Freidenberg's translation of line 29, "Proiskhozhdenie grecheskogo romana," 26.

43 Frank-Kamenetskii to Freidenberg, 26 June 1924, 3: 94-95; for further discussion of the symbolism of the mythical elements see his "Voda i ogon'," 130 , 156-59.
} 
suitor, Thamyris, envious of her attraction to Paul, denounces Paul and brings him to the hegemon for punishment. At the story's end, Thecla and Paul are united by their faith in God and love of God, while Thamyris is punished for his impure love for Thecla and evil feelings towards Paul. He dies a lonely death.

In her outspokenly "Marrist" paper, Freidenberg discarded the etiology of individual mythological plot lines and suggested instead a uniform general model: "the outline of an emblem [figura gerba], where the idea of woman is taken to be death-life and destruction-rebirth." ${ }^{44}$ "Thamyris" addressed polemically both Frank-Kamenetskii and Marr. Frank-Kamenetskii held the opinion that linguistic data from different countries, languages, and epochs cannot provide evidence of the "localization of an idea" in cultural history. Freidenberg, by contrast, followed Marr and considered a broad range of parallels obtained from Homer, Pausanias, and Tacitus, as well as from Marr's own conjectural reconstructions of archaic eponyms and toponyms (word-lexemes that indicated topographical regions). ${ }^{45}$ The semantic analysis of cultural myths in this article, however, conformed to Frank-Kamenetskii's conclusions regarding the plot's architectonics: "The motif of victim and destroyer reveals their identity, the complete unity of the deity and its enemy, the one punished and the one who punishes." 46

Supported by Frank-Kamenetskii and encouraged by the similarities in their approaches, Freidenberg moved swiftly to refine some of the more justifiable aspects of Japhetidology. Marr, with his constant search for new ideas, appealed to the creative aspects of her personality; but her intimate friendship and close professional contacts with FrankKamenetskii opened her eyes to modern European philosophy.

\section{Frank-Kamenetskii and Freidenberg Assimilating Cassirer's Philosophical Principles}

In the mid-1920s Frank-Kamenetskii was working on a methodical grouping of the empirical data, terminology, and theoretical explications meant to "reveal the main features of primeval consciousness, characterized by Marr as prelogical thinking," and he was engaged in comparing Japhetidology to Cassirer's treatment of the fundamental presuppositions of language and of the principles of conceptual thinking

\footnotetext{
44 O. Freidenberg, "Thamyris," Iafeticheskii sbornik 5 (1926): 72-81, translated in SSL 27:1 (1990-91), 33-40. The quotation is from p. 38.

45 SSL 27:1, 35, 38-39 (references are to "On the Interpretation of the Name 'Homer" and "The First Mediterranian House" by N. Ia. Marr).

46 Freidenberg, "Thamyris," 34, 38 (references are to "Water and Fire in Biblical Poetry" by Frank-Kamenetskii).
} 
in general. ${ }^{47}$ For his "Prelogical Thinking in Light of Japhetic Theory and Philosophy," Frank-Kamenetskii brought together the most representative works of Marr and Cassirer dating from 1922 to 1925, including Die Begriffsform im mythischen Denken (1922), Philosophie der symbolischen Formen (1923), Die Sprache (1923), Das mythische Denken (1925), and Sprache und Mythos (1925). ${ }^{48}$

Marr was represented in Frank-Kamenetskii's work by his programmatic study Following the Landmarks of Japhetic Theory (Po etapam razvitiia iafeticheskoi teorii), as well as by publications in the Proceedings of the Russian Academy of Sciences and the Proceedings of the Russian Academy of the History of Material Culture. ${ }^{49}$ Part 1 of Frank-Kamenetskii's paper bore the subtitle "Do-logicheskoe myshlenie" ("Prelogical Thinking") and provided a "bilingual" Marr-Cassirer compendium. $^{50}$ As Frank-Kamenetskii presented the case, phenomena that Cassirer considered "symptoms of 'indeterminateness' found in the mythic thinking and in language" of several tribes (Bantu, the Yao of British Central Africa, and others), Marr distinguished as the main characteristics of "prelogical" (do-logicheskoe), diffuse thinking. ${ }^{51}$ As Cassirer wrote in the introduction to Das mythische Denken, to under-

47 Frank-Kamenetskii, "Pervobytnoe myshlenie," 76.

${ }^{48}$ Ibid., 76, 72. In Russian scholarly language, the prefix do provides a combined empirical and speculative interpretation of the phenomena and offers a cluster of meanings equal to 'pre', 'pro', 'pra', 'proto', which all are also present in the lexicon. Cf. Kongress protoistoricheskikh $i$ doistoricheskikh nauk' (congress of proto- and prehistorical sciences); 'progress preistoricheskikh izyskanii' (progress in prehistorical research) in B. L. Bogaevskii, Orudiia proizvodstva $i$ domashnie zhivotnye Tripolia (Leningrad: Sotsekgiz, 1937), 7. Elsewhere, do corresponds to 'ante': 'dopotopnyi' (antediluvian); compare also: 'praotsy' (forefathers), 'proobraz' (pre-image), but 'prototip' (prototype).

49 N. Marr, Po etapam razvitiia iafeticheskoi teorii (Moscow-Leningrad, 1926), Doklady Rossiiskoi Akademii Nauk (DRAN), 1924; Izvestiia Rossiiskoi Akademii Istorii Material'noi Kul'tury (IRAIMK), 1925.

50 "Pervobytnoe myshlenie," 74-111. For an in-depth discussion of FrankKamenetskii's bilingual Marr-Cassirer lexicon, it is worth mentioning that even Marr's notorious "Language is a means for production" (Iazyk-orudie proizvodstva) - a phrase which Stalin used as an example of sheer gibberishlends itself to a legitimate translation into Cassirer: "speech is the vehicle of any world perspective" (Language and Myth, trans. Susanne K. Langer [N.Y: Dover Publications, 1946], 31); and "the forms of mythical invention reflect the forms of human practices" (ibid., 41).

51 Cassirer, Language and Myth, 72; Marr, "Iafetidy," Vostok 1 (1922): 87; and Frank-Kamenetskii, "Pervobytnoe myshlenie," 73, 74, 123, 124. Following Marr's terminology, Frank-Kamenetskii uses "primeval" (pervobytnoe) and "prelogical" (do-logicheskoe, with the hyphen) alternatively. 
stand the entire content of a myth as a subjective illusion which the myth owes to its very origin, actually means to approach a network of problems related to an integral system of different forms of spiritual expression. In order to understand this integral significance of myth, one has to start with the origin of the primary forms of spiritual culture: "Und dass der Mythos in diesem Ganzen und für dasselbe eine entscheidende bedeutung besitzt,- - das ergibt sich sofort, wenn man sich die Genesis der Grundformen der geistigen Kultur aus der mythischen Bewusstsein vor Augen hält."52

Following this idea, Frank-Kamenetskii sought to define through forms of language (Cassirer's "Sprachbegriffe") the general and individual designators of mythological thinking. He defined the intrinsic qualifications of the thought processes that determined the comprehension of reality in terms of intuition rather than in categories of general and scientific concepts; and he arrived at the conclusion that language is correlative to the intrinsic qualifications of the entire sum of meanings contained in the collective experience of a people. He adapted Cassirer's central idea that on the intuitive level "the word denotes that thought content is not a mere conventional symbol, but is merged with its object in an indissoluble unity," and that language as a whole is an activity, an experience which facilitates the intuitive elaboration of metaphors that charge the objective world with meaning. ${ }^{53}$ Frank-Kamenetskii used this philosophical postulate to develop his hermeneutic treatment of metaphor. He demonstrated how poetic metaphor internalized a variety of forms and contents external to the verbal arts and rendered them through the categories of its own discourse; how it perceived the world through its own prism of animistic totemism, cosmogony, and religion. As a follower of Cassirer, Frank-Kamenetskii disputed the arbitrariness of individual metaphorical images in poetry; he insisted that the expressive plane in metaphors, like the monotheistic and polytheistic symbols in religions, comes about as "the secondary reconstitution of archaic concreteness." In "Survivals of Animism in Biblical Poetry" (1926), "Vegetation and Agriculture in the Poetic Images of the Bible and in Homer's Similes" (1929), "Parting as a Metaphor for Death in Myth and Poetry"(1935), and his last article "Adam and Purushah: Cosmos and

\footnotetext{
52 Ernst Cassirer, introduction to Cassirer, Mythical Thought, vol. 2 of Philosophy of Symbolic Forms, trans. Ralph Manheim (New Haven: Yale University Press, 1953), viii-ix.

53 Cassirer, Language and Myth, 58. An expert in contemporary semiotics can readily recognize in Frank-Kamenetskii's molding of Marr and Cassirer the signifier/signified dichotomy. It should be noted, however, that Saussurian terminology was not used by Marr, Frank-Kamenetskii, and Freidenberg.

54 Frank-Kamenetskii, "Pervobytnoe myshlenie," 152.
} 
Microcosm in Judaic and Indian Cosmogony" (published posthumously in 1938), he discussed metaphor as one of the historical forms of human consciousness. ${ }^{55}$ While working on his articles, Frank-Kamenetskii gave talks and delivered lectures to his co-workers in the sector of mythology, so that they became familiar with Cassirer's writings as soon as they had been published in Germany.

Through his lectures and articles Frank-Kamenetskii executed a thorough translation of Marr's Japhetidology into Cassirer's philosophical anthropology: the title of his paper and its two-part composition (part 1, "Pre-logical Thinking"; part 2, "Language and Myth") suggest a dual interpretation of prelogical thinking both in light of Japhetic theory and within the framework of Cassirer's philosophy. This transposition of neo-Kantian epistemology onto Marr's amorphous, philosophically eclectic teachings on glottogony and logogenesis had a very strong impact on Freidenberg. A scrupulous reading of the entire body of her mature scholarship reveals her peculiar manner of clothing thoughts with words: as an author she was a neo-Kantian thinker in Marrist garb.

However, it would be a grievous slight to the moral integrity of both Freidenberg and Frank-Kamenetskii to attribute the duality of their approach to ideological disguise or political camouflage. On the contrary, the incorporation of Cassirer into their philological framework signaled a new phase in the organic development of their own scholarship, and of the humanities as well. ${ }^{56}$ It also encouraged them to explore Cassirer's methods in areas which he himself did not investigate in depth.

55 I. G. Frank-Kamenetskii, "Perezhitki animizma v bibleiskoi poezii," Evreiskaia mysl' (1926): 43-80; "Rastitel'nost' i zemledelie v poeticheskikh obrazakh Biblii i v gomerovskikh sravneniiakh," Iazyk $i$ literatura 4 (1929): 123-70; "Razluka kak metafora smerti v mife i v poezii," Izvestiia AN SSSR 2 (1935): 153-73; "Adam i Purusha (Makrokosm i mikrokosm v iudeiskoi i indiiskoi kosmogonii)," in Pamiati akademika N. Ia. Marra (Moscow-Leningrad: AN SSSR, 1938), 458-76. Freidenberg included a brief review of the above works in the introductory chapter of The Poetics of Plot and Genre, 34-37.

${ }^{56}$ I am much indebted to Dmitrii Iunov (St. Petersburg), who shared with me the results of the recent research in the Archive of Russian Academy of Sciences he undertook for compiling an introductory article to the Complete Works by V. N. Voloshinov. Iunov ascertained that in 1931 Voloshinov began translating Cassirer's Philosophie der Symbolischen Formen (Arkhiv AN Rossii, f. 155, op. 2, ed. khr. 137). Iunov also found out that according to the "working plans" (rabochie plany) of IRK for 1930-33, I. Frank-Kamenetskii, M. Azadovskii, V. Voloshinov, O. Freidenberg, A Kholodovich, L. Tsyrlin, and A. Beskina were assigned to prepare for publication a collection Contemporary West European Literary-Aesthetic Theories (E. Cassirer, Dilthey, O. Walzel, and others). The works of Western theorists were not published. 
Cassirer's philosophical anthropology had a strong impact on Freidenberg's views. From his philosophy she learned that "the act of consciousness that gives birth to one or other of these forms-to science, to art, and to language-does not simply discover and reproduce an ensemble of pre-existent objects. This act, the processes that give birth to it, lead rather to this objective universe, and contribute towards constituting its being and structure. The essential function of language is not arbitrarily to assign designations to objects already formed and achieved, language is rather a means indispensable to that formation, even of objects." $" 57$ Like Frank-Kamenetskii, Freidenberg found in Cassirer a defense protecting her from Marr's eclecticism and reductionism.

In Freidenberg's scholarship, the assimilation of Cassirer's philosophical principles softened and modified the rigidity of Marr's formula on the supremacy of the collectively productive labor experience in the cultural development of mankind. Cassirer made it possible to place language, rather than the relations of production, at the base of her cultural studies. Through Cassirer, Freidenberg also came to realize that, unlike the Marrist syncretic approach, her method required a variety of typological models; she also realized that her genetic treatment of cultural development was incompatible with evolutionary schemata. Strategically, the elimination of evolutionary interpretations provided Freidenberg with a first line of defense protecting her reconstructions from eclecticism and arbitrariness. Nor could the modern arts and literatures easily penetrate the terrain of her studies due to her rejection of the evolutionary approach. The second line of defense, built along the temporal and spatial limits of primeval consciousness, was constructed in agreement with the Kantian interpretation of time and space postulating that time and space "are real entities" and that "space is pure awareness or mental visualization." 58 Since the mental organization of the world is possible only within a temporal and spatial perspective, Freidenberg quietly deemed as groundless the Marrist transpositions of paleontological methods onto contemporary cultures, such as the incorporation of modern languages into the paleontological framework. And since time and space are indispensable forms of cognition, a supporter of the genetic method has to take into consideration the boundaries of the temporal and spatial horizon of primeval man. The Kantian rule of "things as they appear externally are juxtaposed in

${ }^{57}$ M. F. Ashley Montagu, "Cassirer on Mythological Thinking," in The Philosophy of Ernst Cassirer, ed. Paul Arthur Schlipp (Evanston: The Library of Living Philosophers, 1949), 362.

${ }^{58}$ An Immanuel Kant Reader, ed. and trans. Raymond B. Blakney (New York: Harper \& Brothers, 1960), 26-27. 
space" remained universally valid; the limited nature of the primeval purview, however, rendered the encompassed images as either adjacent figures or antinomic identities; examples would be the mythological unities of light and darkness or life and death.

Publicly, Freidenberg remained close-mouthed about her methodological disagreements with Marr. An explanation of her reticence can easily be found in her dependent role as "foster child" in the family of the genuine Japhetidologists, in her modest rank of junior research scholar at the Japhetic Institute, and in her uncouthness in academic debates. In her retrospective diary, she never fails to mention all of these rather significant biographical details, but as The Race of Life provides a meta-biographical commentary to Freidenberg's "works and days," one finds there a more thorough explanation of the problem. Here she states:

I worked on my Poetics (or "Procris," as I called it) at full speed. ${ }^{59}$ I proceeded from the standpoint of those distinctions that turn out to be identities (a new lover of Procris appears to be her old husband).... For the first time in "Procris" I developed a complete system of ancient semantics. I took images in their multivariousness and demonstrated their unity. I sought to establish the regularity of building the forms and distinguishing their variabilities. Having summarized and systematized all the semantic meanings, I discussed their proper molding, their morphology. I introduced a chaos of plots, myths, rituals, and things as the law-governed system of definitive meanings. There were many different ideas and inventions. Philosophically, I wanted to demonstrate that literature, like natural history and the exact sciences, can provide a source material for the theory of cognition. In identities I sought to reveal dissimilarities, in dissimilarities to find identities. That was my invariable statement. The entire Greek novel provided just such an example of this. As to the factual material-there I had many particular ideas, many new results: the origin of drama, of chorus, of metaphoricalness in lyrics. To reveal the genetic semantics and to trace connections amidst the most diversified things-I was a great master of it!... Professional contacts with Frank-Kamenetskii, our meetings in the Japhetic Institute, discussions, his visits to our place and mine to his provided me with the opportunity for a thorough, far-reaching exchange of ideas and rewarded with understanding. We uncovered our surprising, absolutely unique affinity of scholarly views. All of my "Procris" as a whole and in

59 The Poetics of Plot and Genre, published in 1936. For the story of Procris, daughter of Erechteus and wife of Cephalus, see Ovid, Metamorphoses 7: 695865 . 
the minutest details was well known to him, and everything which he wrote or read he related to me with all the emotional nuances. Those years represented an intercourse of two scholarly souls, and our intimacy was so close that one individual personality immersed into the other. Two distant and different people, we were made into twins by nature.

Frank-Kamenetskii worked primarily on metaphor, on its semantic aspect. His every talk, every paper were events for me. At first I did not notice that for him the ancient times were merely a substratum, yet for me the begetters of the present. Yielding, for a while, to Marr in his interpretation of the Japhetides and to Frank-Kamenetskii in his treatment of the proto-Palestinian substratum, I too sought all sorts of protos-, pres- , and nons-: pre-Graecian, non-Graecian myths, and so on. But in the main part of the "Procris" I independently resisted all the substrata. Soon, in Marr, substratum was rendered as "stage," and he, like Frank-Kamenetskii, started to explain all dissimilarities through differences in the process of stage development. The theory of development by stages has always been alien to me. I found it to be superficial and evolutionist. For me the most interesting thing consisted in the fact that dissimilarities determined every life manifestation, every functioning, every existence. This was the original and the only possible form of expression of the unity of the universe. It was impossible to object to the theory of development by stages. But why didn't Marr look with suspicion at the fact that specifically this theory of development by stages was accepted immediately by everybody!

Я уже полным ходом писала свою Поэтику, которую назвала Прокридой: я хотела поставить во главу угла мысль о различиях, которые оказываются тождеством (новый возлюбленный Прокриды предстоит перед нею, как ее старый муж).... В Прокриде я впервые давала полную систему античньг семантик. Я брала образы в их многообразии и показывала их единство. Мне хотелось установить закон формообразованья и многоразличия. Охватив и систематизировав смыслы, я рассматривала их правильную отливку, морфологию. Хаос сюжетов, мифов, обрядов, вещей становился у меня закономерной системой определенных смыслов.

Тут было много идей и затей. Философски, я хотела показать, что литература может быть таким же матерьялом теории познанья, как и естественные или точные науки. Я хотела открыть в одинаковом различное, в различном одинаковое, - моя постоянная мысль! Весь греческий роман 
обращался тут в простой частный случай. Что до фактического матерьяла, то тут у меня было много конкретных мыслей, много новых результатов: происхождение драмы, хора, лирической метафористики. Вскрывать генетическую семантику и находить связи среди самого разнородного-на это я была мастер!...

Последующие научные контакты с Франк-Каменецким наши встречи в Яфетическом институте, беседы, визиты его к нам и мои к нему - давало мне возможность много, глубоко и обильно обмениваться мыслями и пониманием. Мы обнаруживали удивительную, совершенно исключительную общность научных взглядов. Вся моя Прокрида, в целом и частях, была ему хорошо известна. Все, что читал и писал он, во всех переживаниях излагалось мне. Эти наши годы представляли собой обмен научными душами, и близость здесь была такова, что индивидуальность одного терялась в другом. Природа создала из нас, чужих двух и далеких людей, близнецов.

Франк-Каменецкий занимался, в основном, проблемой метафоры, ее семантической стороной. Каждый его доклад, каждая его работа были событием для меня. Я вначале не замечала, что для него прошлое было субстратом, для меня созидателем настоящего. Поддаваясь Марру в его трактовке яфетидов и Франк-Каменецкому в трактовке до-палестинского субстрата, я искала (одно время) всякого “до”, догреческих, ино-герческих, мифов. Однако, в главной части Прокриды, я самостоятельно восставала против субстратов. Вскоре у Марра субстрат обратился в стадию, и для него, как для Франк-Каменецкого, всякое различие стало объясняться разницей стадий единого процесса развития.

Теория стадиальности всегда была мне чужда. Я находила ее поверхностной и эволюционной. Для меня самое интересное лежало в том, что различие определяло всякую жизнь, всякое функционирование, существование: это была исконная и единственно возможная форма выражения мирового единства. Открыто возражать против стадиальности было нельзя. И как Марру не показалось подозрительным, что именно теория стадиальности была всеми сейчас же принята! (3: 202, 204-05) 


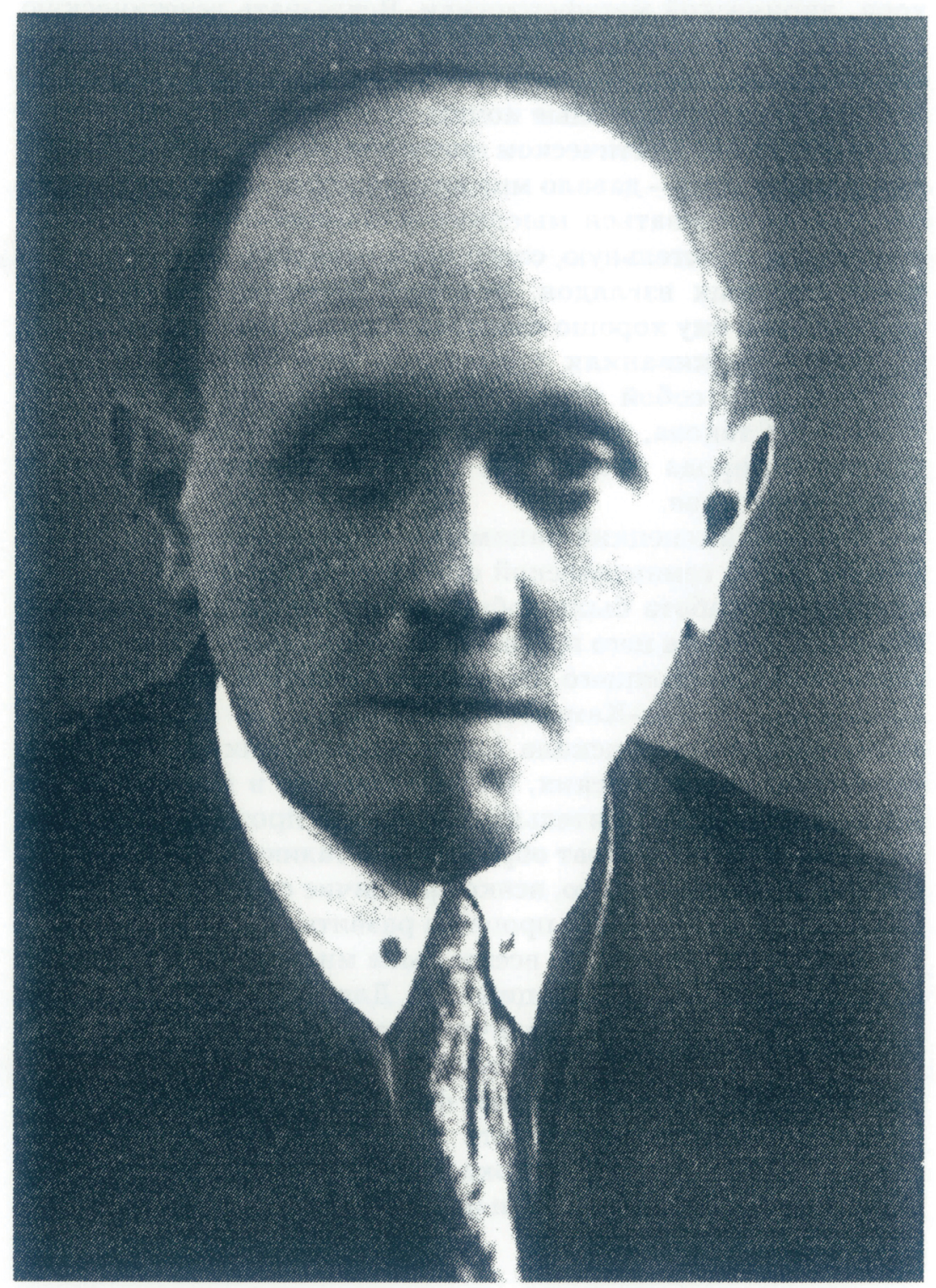

I. G. Frank-Kamenetskii 


\section{Becoming a Mature Scholar}

Wenn im Unendlichen dasselbe Sich wiederholend ewig fliesst, Das tausedfltige Gewölbe Sich kräftig ineinander schliesst.

Goethe, "Sprüche in Reimen" 
Chapter 4

Ol'ga Freidenberg, a Cassirer Scholar in Marrist Garb

\section{A. To Yield or Not to Yield to the Authority of Marrism?}

$\mathbf{V}$

ia Frank-Kamenetskii's interpretation of Cassirer, Freidenberg arrived at a new systemic approach to archaic cultures which now represented for her an integration of the "knower" and the "known thing." Formulated in her terms, collective consciousness, rather than merely reflecting the nature of the object existing externally, was endowed with the capacity for self-reflection and for producing new more complex mental images and concepts from its own, internal resources. The conclusion points to Freidenberg's original way of adapting Cassirer's thesis that at every stage of human social development, language as a whole provides a "symbolic form which points beyond itself toward still higher formations." Indeed, Freidenberg's postulate that "over the course of history, one and the same thing takes on different forms, subjected as it is to different interpretations"- the statement repeated insistently in the diaries, in the articles, in The Poetics of Plot and Genre (the source of the quote) and in the Prolegomenon to the Theory of Ancient Folklore (Vvedenie $v$ teoriiu antichnogo fol'klora)found its epistemological justification only with the acceptance of Cassirer's philosophy. ${ }^{2}$ The forms of language, or the different means by which things were named, provided Freidenberg with an objective criterion by which it would be possible to define the fundamental structures of the human intellect as they progressed through cultures. It is in this sense that Frank-Kamenetskii's summary of Cassirer's understanding of the character of human knowledge "which defined and deter-

\footnotetext{
${ }^{1}$ Robert S. Hartman, "Cassirer's Philosophy of Symbolic Forms," in The Philosophy of Ernst Cassirer, 292; Hartman refers to Ernst Cassirer, Philosophie der symbolischen Formen, 1: 122.

${ }^{2}$ Freidenberg, Poetika siuzheta, 13-14; $M L, 11$; see also my introduction to $S S L$ 27: 1 (1990-91): 9, 13-15.
} 
mined the circle of humanity" turned out to be indispensable for her further work. ${ }^{3}$

In order to accept Freidenberg's maxim on the genesis of cultural forms, one has to be sure that it provides answers to the following questions:

1) If autochthonal mythologies all follow the pattern which envisions the creation of cosmos (order) from chaos (disorder), and then transpose the notion of celestial order onto human life and society, which first appears to be disorganized, from where, then, does the idea of universal order originate?

2) Is the notion of "order" obtained through the development of collective consciousness? Is not this concept born in the minds of modern philosophers and then applied as a projection onto the past?

3) How should one conceive of this "one and the same thing" that "takes on different forms"? Is it a "real thing" whose constituent elements are to be singled out and analyzed, or is it a mental abstraction, a figment of our modern philosophical contemplations?

4) If "one and the same thing" represents an archetypal unity, the antinomic identity, how can it be approached via the architectonics of "different forms"? Can the aggregate meaning of antinomic identity be adequately expressed through plurality?

An answer to these questions can be found in "The Semantics of the Structure of the Puppet Theater." The work, delivered at the meeting of the Academy of Material Culture on 20 May 1926, does not yet contain direct references to Cassirer, but it does reveal Freidenberg's thorough reconceptualization of the paleontology of culture in view of the Philosophy of Symbolic Forms as well as her own way towards assimilating the main thrust of Cassirer's ideas. ${ }^{4}$ Freidenberg's rationale suggests that Cassirer's philosophical anthropology is a strain of thought compatible with Marr's semantic paleontology of culture. The introductory

${ }^{3}$ Ernst Cassirer, An Essay on Man: An Introduction to a Philosophy of Human Culture (New Haven: Yale University Press, 1951), 68. Cassirer himself considered this work (written in 1944) to be the cumulative summary of "psychological, ontological, epistemological questions" (ibid., vii) he dealt with in his earlier writings of 1923-29.

4 "Semantika postroiki kukol'nogo teatra," prepared for publication in 1926, published posthumously in O. Freidenberg, Mif $i$ teatr (Moscow: GITIS, 1988), 13-35. Fragments from this paper were published under the title of "Semantika arkhitektury vertepnogo teatra" in Dekorativnoe iskusstvo SSSR 2 (1978): 4144, and translated into English as "The Architectural Semantics of the Vertep Theater," SSL 27: 1 (1990-91): 41-54. 
passage provides the formula and "the general stamp" of "one and the same thing."

"Why semantics?" Freidenberg asks.

"Because there is nothing, absolutely nothing without the signification of meaning. In the cosmos, we indicate it as lawgoverned regularity, and in the process of this regularity we try to discern its universal meaning. In various ordinary occupations of men we also distinguish the general stamp of meanings which humans have given to things. This is the semantic meaning. Before we unfold the law-governed regularity of the cosmos, we discover the meaningfulness of the social world, for this is the system of meanings in which we live, without being aware of it." 5

Freidenberg approaches the cosmos, the realm of infinity and supersensoriness, through sense perceptions and through "finite" human practical interests. She charges the realm of infinity and the finite world with semantic validation and treats both material and verbal structures as repositories of meanings, so that the history of things and of words becomes amenable to study through the "signification of meanings": semantics and etymology. Freidenberg approaches the material object, the architectural construction, and the structure "as a philologist would a sequential text; she regards each detail of an object as though it were a word that had a so-called 'etymology' in addition to its present meaning and its history." ${ }^{6}$ Philological terms and methods of investigation are applied to the study of puppets, statues, the vertep theater, the construction of temples, and other material things. As Nina Braginskaia observes, "the 'etymology of a thing'-that is, its meaning 'according to its origins' that no longer has any current import for its present function, that has been completely effaced by history and has become lost in a multitude of later reinterpretations-can, Freidenberg asserts in her paper, be restored, preserved, as it is in the very form of this thing." 7

Freidenberg's analytical approaches agree with Cassirer's thesis that language is the main repository of meanings and that there is nothing in the world that is able to "claim independence from the power of the word ... for, as myth and religion seek to transcend the bourne of language, they arrive therewith at the limits of their own creative and formulative power." 8 Equipped with the methods that enabled the trans-

\footnotetext{
5 "Semantika postroiki," 13.

${ }^{6}$ Cf. Braginskaia's note prefacing the publication of Freidenberg's "Architectural Semantics" in Soviet Studies in Literature, 41.

7 Ibid., 41.

${ }^{8}$ Cassirer, Language and Myth, 79.
} 
position of Cassirer's epistemology onto Marr's paleontology of culture, Freidenberg utilized some of the former's observations for the benefit of her own genetic approaches. In "The First Mediterranean House and its Japhetic Denominations among the Greek and Roman Peoples" Marr wrote about the common Japhetic substratum he discovered in the worldviews of primeval tribes from the Mediterranean region. Primeval people, Marr believed, used the same semantic element to indicate different "constructions," beginning with the construction of towns and other settlements, and ending with "eternal dwellings" created (in fantasy) or built (in stone) for the repose of human remains and holy relics. Marr thus established a semantic identity between the ideas indicating 'house', 'temple', 'tomb', 'town', 'necropolis', 'sky', and 'underworld'. He suggested that the general notion of the firmament (viewed as a solid arch or vault) was used for the signification of different meanings, such as 'heaven', 'room', 'cavity', and 'hell'. Marr further identified 'sky' with the higher world-the firmament for ethereal beings; he envisioned 'cavity' as a hollow space which either provided dwelling for the cave man or represented the lower world where the dead abide; and he treated 'room' as the simplest man-made construction, "the first Mediterranean house." ${ }^{9}$ Freidenberg also referred to Marr's brochure "Tracing Tribal or Class Experiences of the Pre-Historical Population of Europe in Russian Speech and Toponymics" (1926), in which he suggested, although in passing, "the semantic identity: 'puppet-deity-skyaltar' (seen as 'throne-armchair-seat' in cult)." ${ }^{10}$

Freidenberg describes the roles which were assigned to human-like effigies in different historical situations: "[D]olls or puppets are to be met in five roles-in folk ritual, in liturgical procession, in puppet theater, in religious mystery, and, finally, in peoples' daily life and customs." ${ }^{11}$ While the roles are different, the semantics, or the aggregate meaning ascribed to puppets, marionettes, statues, figurines, and dolls is determined by the structure and by the pragmatic destination and sym-

\footnotetext{
${ }^{9}$ N. Ia. Marr, "Pervyi sredizemnomorskii dom i ego iafeticheskie nazvaniia $u$ grekov 'megaron', u rimlian 'atrium'," Izvestiia Rossiiskoi Akademii Nauk (IRAN) 18 (1924): 225-36. Freidenberg refers to pp. 231, 226-28 of Marr's study (Mif $i$ teatr, 18-19, 29); she also mentions Marr's "Otchet o poezdke k vostochnoevropeiskim iafetidam," Iafeticheskii sbornik 3 (1925), 1-64. In "Pervobytnoe myshlenie," 74-78, Frank-Kamenetskii referred to the same articles of N. Marr to demonstrate similarities between the Japhetic theory and the Philosophy of Symbolic Forms.

${ }^{10} \mathrm{~N}$. Marr, Iz perezhivanii do-istoricheskogo naseleniia Evropy, plemennykh ili klassovykh, $v$ russkoi rechi i toponimike (Cheboksary, 1926), in Freidenberg, Mif i teatr, 35.

11 "Semantika postroiki," Mif i teatr, 15.
} 
bolic interpretation of the spatial construction within which the effigies are placed. Approached from the position of architectonics, the vertep theater, the church, the classical temple, the sanctuary, and the tombdistinct structures that they are-become semantically comparable, and their common semantic essence can be identified as the "house of a deity."

Freidenberg juxtaposes the vertep theater and the church/temple from the architectural standpoint and defines their material, pragmatic affinities. ${ }^{12}$ Connecting the vertep theater and the church from the architectural perspective, Freidenberg demonstrates "their identity from the purely material standpoint." From this material standpoint, we can find in both "a sanctuary, a phenomenon familiar to us both from antiquity in pagan and biblical times and from church archeology. The aediculae were arks or tabernacles; we ought to mention this so that the idea of sanctuary will begin to emerge before us. ${ }^{13}$ The aedicula is at once a little house, a room or niche, and a small shrine. This is the same sanctuary with imagines [ancestor portraits] as our raek, our vertep, and our marionette theater, with the same representations of gods or saints inside, the same shape of a little shrine, a little house-box shrine that is found in the sanctuary and-what is especially indicative-sometimes stands on the altar." 14 Freidenberg continues with the analysis of architectural structures and finds the common semantic denominator for three different groups of constructions: the human dwelling ("the house" in its most common, pragmatic sense); the temple ("the house" of a deity), and the tomb ("the house" of the deceased). Her series of semantic identities continues:

the deity is embodied in food and drink, the vessel is linked to a box and the temple, the table on which the deity lies is symbolized as a 'heavenly place' and simultaneously as a 'tomb'; the symbolism speaks directly of it as 'Body of the Lord' and places a sign of semantic equivalence between the deity, the table,

12 Freidenberg described the vertep as a portable two-story construction, a little house with a peaked attic; the puppet show and the action took place from within this little house; the topical frame of the performance was fixed by allocation to the Christmas cycle and divided by emotional expressive planes: a comic play in the lower level, and the mystery-play in the upper level. Ibid., 1617.

13 As Freidenberg notes in "The Architectural Semantics of the Vertep Theater," the term aediculae "was also used for the seats high up. They had a bed for gods and rulers, and from there Roman emperors watched competitions," SSL 27: 1 (1990-91): 50.

14 Ibid., 43. 
heaven, and the tomb; but, hidden by the canopy, this table is also identified with the vessel where the deity abides. ${ }^{15}$

This lengthy passage is worth quoting, for it makes one understand Freidenberg's essential modification of the standard paleontological approaches. Actually, only the spatial vectors pointing to the signification of meaning-cosmos, earth, and the netherworld-have been preserved in her study from Marr's analysis of the "Mediterranean House." On the other hand, the passage demonstrates that already in 1926 Freidenberg was quite familiar with Cassirer's theory of language and myth relationships. Her treatment of material architectural structures and architectonics in their semantic intersection advances to the foreground the transference of meanings in human consciousness. This notion points directly to Cassirer's understanding of metaphor, which provides "the conscious denotation of one thought content by the name of another which resembles the former in some respect, or is somehow analogous to it." According to Cassirer, "metaphor is a genuine translation." It translates within and between cultures and forms of consciousness: "the two concepts between which it obtains are fixed and independent meanings, and betwixt them, as the given terminus a quo and terminus ad quem, the conceptual process takes place, which causes the transition from one to the other, whereby one is semantically made to stand proxy for the other."16

"The Semantics of the Structure of the Puppet Theater" represented a prominent achievement in Freidenberg's development as an original theorist and scholar. With the completion of this paper, Freidenberg reached a turning point in her quasi-Marrist interpretation of the morphogenesis of prelogical thinking; and having assimilated the fundamentals of Cassirer's philosophical creed, she outlined her main area of concentration-the semantics of cultural forms in archaic folklore and early Greek literature. The paper opened a perspective for her works of the next fifteen years: from "Three Plots or the Semantics of One" (1929), continuing with The Poetics of Plot and Genre (1936) and "On the Semantics of the Folkloric Proper Names 'Makkus' and 'Mariia'" (1936), to "The Semantics of the First Thing" (1943). In this last paper, written in the besieged city of Leningrad, facing starvation and death, Freidenberg summarized the results of her own scholarship and reconfirmed that the architectural constructions of the oldest haunts of primeval people, as well as the first furniture and interior designs, were implemented in imitation of the archetypal model of the "two types of

15 Ibid., 45.

${ }^{16}$ Cassirer, Language and Myth, 86-87. 
dwellings known to primitive man: hell and heaven, in which, in his imagination, he lived together with the deceased and with the gods." ${ }^{17}$

In the paper on the vertep theater, the common semantic connotations of different cultural forms in the arts, religion, and daily life are drawn on the basis of symbolic relations or functions. Thus, seeking the common semantic key to the architectonics of the funeral and the wedding processions, of the banquet table, the temple's altar, and the platform (stage) of the puppet theater, Freidenberg states:

Now the funeral platform, the catafalque with its bed-tomb, high table, and canopy, is presented to us in the form of an altar. The table with the deceased lying upon it and the feast table with the food on which the movable little figurine of the corpse or the puppet in its grave lies duplicates the idea of the altar with the sacrifice lying upon it, or the Holy Table with the "Body of the Lord," the divine bread and wine. Hence, the puppet theater on the table is the same thing in terms of its idea as the figurines of corpses on the feast table. ${ }^{18}$

This type of transference links Freidenberg's semantic interpretations to the morphologic-functional approach of Vladimir Propp. A more detailed discussion of the Freidenberg-Propp exchange will follow. For current purposes, however, it is necessary to point to the main prerequisite of Propp's method, which Freidenberg also takes into account. Propp states that in the tale the functions of the dramatic personae are not to be confused with their acts. While "identical acts can have different meanings," functions "serve as stable, constant elements in a tale" and are defined from the point of view of their significance for the course of the action (or, to translate Propp's terminology into Freidenberg's lexicon, functions are drawn on the basis of their relation to the semantics of the plot). ${ }^{19}$

In The Race of Life one finds a valuable auto-commentary to "The Semantics of the Structure of the Puppet Theatre" in which Freidenberg claims that her treatment of semantics was different from Marr's:

For the first time, I introduced the thing along with the word and with the action. That was not Marr's influence in the least. From my student years, I was captivated by Usener and his Deluge Legends and by the unforgettable semantic writings of the German archeologists. Marr was but "a civil registrar's

${ }^{17}$ Freidenberg, "Semantika pervoi veshchi," Dekorativnoe iskusstvo 12 (1976), 20.

18 Freidenberg, "Architectural Semantics," 45-46.

19 Propp, Morphology of the Folktale, 21. 
office" which legalizes the old affair. While nobody worked in my vein on genre, with plot it was another story. I myself did not quite realize the entire meaning of those studies of mine. At one point I even believed that I worked in the area of religion, mythology-in any other field but literature. After me Marr and Frank-Kamenetskii developed an interest in plot. Their interest was determined entirely by semantics, whereas for me, beginning with the novel and "Three Plots," semantics was the main goal for defining the morphology-the regulatory law of the development of forms. (3: 203-04) ${ }^{20}$

Впервые я вводила, рядом со словом и действием, вещь. Это вовсе не было влияние Марра. Со студенческой скамьи меня взял в плен Узенер своими "Сказаниями о потопе" и незабываемые семантические работы немецких археологов. Марр был тем “отделом гражданских дел", который узаконивает старую связь. Если над жанром никто в моем духе не работал, то иначе вышло с сюжетом. Я плохо понимала все значение своих работ, и даже думала,что работаю в области религии, мифологии, - чего угодно, только не литературы. Интерес к сюжету появился после меня и у Марра и у ФранкКаменецкого. Этот интерес всецело определялся семантикой, в то время как для меня, начиная с романа и Трех сюжетов, семантика была целью определения морфологии, - закономерности формообразования.

\section{B. An Attempt at Creating "Marrism with a Human Face"}

In her papers "The Myth about Joseph the Beautiful" and "Blindman over the Precipice" (1932) Freidenberg relied on Frank-Kamenetskii's resemantization of archaic cultural forms within new formulaic themes and adapted Cassirer's statement that in prelogical thinking the correlation between the part and the whole differs fundamentally from the causally determined nomenclature. "Different items bear the same name and are subsumed under the same concept whenever their functional significance is the same, i.e., whenever they hold the same place or at least analogous places in the order of human activities and purposes." ${ }^{21}$ Following this interpretation of the stable functions and their

${ }^{20}$ Freidenberg refers to the classical study by Herman Usener, Die Sintfluthsagen (Bonn, 1899), to her own master's thesis on the genesis of the Greek novel, to the paper "Three Plots or the Semantics of One," and to Poetika siuzheta i zhanra.

${ }^{21}$ Cassirer, Language and Myth, 40. 
significance, Freidenberg singled out the integral connotation of being barren (respectively: sterile, infertile, arid, poor) and traced transformations of this primeval "mythico-religious predication" (another borrowing from Cassirer and Frank-Kamenetskii) through individual images in the Bible, in Aristophanes, and in Shakespeare. ${ }^{22}$ Her projection of the story of Joseph the Beautiful against a totemistic background treated individual manifestations of the person's self in terms of collective representations, and brought about a recontextualization of the biblical plot structures. The fundamental individual characteristics of the herohis chastity and voluntarily chosen celibacy-were shifted from the ethical to a lower semantic plane of representation, and there rendered as equivalents to everything futile and fruitless. In this study, the most characteristic features of the Judaic religious worldview which pointed to the emergence and comprehension of ethical categories of consciousness were rendered as polysemanticized expressions of an archaic sensorial "symbol-concept" (Cassirer). In the poetic metaphors of moral fortitude and voluptuousness, as those are known from the biblical legend, Freidenberg discerned the "objectivation" of the totemistic prohibition put on Heaven and Earth - the sacred progenitors of every living thing (Frank-Kamenetskii).

In "Blindman over a Precipice" she analyzed archetypal images which underlay the plot structures of a wide range of texts: from Aristophanes' comedy Plutus to Shakespeare's tragedy King Lear. Here the totemistic notion of fertility was rendered through the metaphors of light, golden rays, gold, and wealth. ${ }^{23}$ To the same issue of Language and Literature Frank-Kamenetskii contributed "Echoes of the Mother-Earth Representation in Biblical Poetry." ${ }^{24}$ His paper owed its understanding of the concepts of 'Being' and of the 'self' to Cassirer, and claimed consubstantiality of archetypal models in Biblical and Graecian mythico-religious lore. Like Freidenberg, Frank-Kamenetskii recognized in the images of the wedding banquet and of sexual intercourse survivals of archaic symbolic forms which rendered in sensory images the notion of common wealth, fertility, and productivity.

Freidenberg's colleagues from the Group for the Paleontological Semantics of Myth and Folklore at the Japhetic Institute of the USSR Academy of Sciences (the so-called "mythical sector") were also influ-

${ }^{22}$ Freidenberg, "Mif ob Iosife Prekrasnom," Iazyk i literatura 8 (1932): 137-58; "Slepets nad obryvom," ibid., 229-44. For the references to Frank-Kamenetskii, who followed Cassirer in his interpretations of prelogical thinking, see 142, 147, $148,151,241$.

23 Iazyk i literatura 8 (1932): 241.

${ }^{24}$ Frank-Kamenetskii, "Otgoloski predstavleniia o materi-zemle v bibleiskoi poezii," ibid., 121-36. 
enced by Frank-Kamenetskii. Their ample references to such works of his as "Survivals of Animism in Biblical Poetry," "Vegetation and Agriculture in the Bible's Poetic Images and in Homer," and "Primeval Thinking in Light of Japhetic Theory and Philosophy" prove that his rendering of Cassirer's philosophical principles as a counterpart to Marrism contributed to the prolific output of the entire academic group. ${ }^{25}$

In 1929 the "mythical sector" prepared a collective contribution dedicated to N. Marr and entitled it Homer and the Japhetic Theory. ${ }^{26}$ Boris Bogaevskii, the editor-in-chief, acknowledged that Marr touched upon the so-called "Homer's question" only in anticipation of opening a Japhetidological perspective onto this problem. Developing a "materialistic insight into Homer studies," Bogaevskii utilized the general culturological observation that forms of collective consciousness mirror the typology of the collectively productive labor experience. The process of cultural development in early antiquity, Bogaevskii presumed, takes on precisely the course described by Marr in his theory of diffusive thinking, which has the stage/structure opposition bring about polysemantic components: semantic clusters. In the history of culture, a new symbolic form (here an epic poem created by the ancient bard) points beyond itself toward more specific, higher representations (the image of an artist, of the performer of the work.) The principal inability of the primeval mentality to find individual expressions for the concept of the 'self' and to discriminate between the collective and the individual ' $I$ ' can be used as a springboard for a thorough revision of the question of collective or individual authorship in the Iliad and Odyssey.

Bogaevskii further considered the Japhetidological treatment of ancient culture along the synchronic and diachronic axes. He believed that the "typological layering, that is, the revealing of the ideal, reflected

25 According to Frank-Kamenetskii's hermeneutic approach, poetic metaphor internalized and rendered through the categories of poetic discourse various contents and forms of experience which were external to the verbal art. The perceptual (emotional) and conceptual (mental) perspectives of animistic totemism, of cosmogony, and of polytheistic religious views were changed and their "accents" shifted. This is how the poetic language of the Bible started to perceive the world through its own prism. A follower of Cassirer, Frank-Kamenetskii insisted that monotheistic and polytheistic religious symbols, as well as metaphorical images in poetry, all come about as results of "the secondary reconstitution of archaic concreteness," rather than by means of arbitrary individual associations. He thus discussed metaphor as one of the historical forms of human consciousness. See his "Perezhitki animizma," 43-80; "Rastitel'nost' i zemledelie," 123-70; "Razluka kak metafora smerti," 153-73; "Adam i Purusha," 458-76.

${ }^{26}$ Iazyk i literatura, no. 4 (1929). 
depth of epos" (tipologicheskoe rassloenie, t. e. raskrytie ideal'noi, otrazhennoi glubiny eposa) has to be conducted "diachronically, along the vertical axis leading down to the paleontology of culture." The quest for the real depth of the individual epic poem of an individual author, conversely, has to be conducted along the synchronistic horizontal axis, "within the limits of chronologically distinguishable stratifications of "cultural background"' ( $v$ predelakh opredeliaemykh khronologicheski naplastovanii "pochvy"). ${ }^{27}$

Bogaevskii limited his editor's introduction to these general observations; he neither explained the character of synchronic/diachronic relations, nor suggested methods commensurable with tracing the oppositions through the epic forms of the Iliad and the Odyssey. He only anticipated that the collective work of the sector would introduce analytical strategies providing a "specific study of the dialectical process." Freidenberg's "The Plot Semantics of the Odyssey" was accepted as an open-ended statement encouraging polemical exchange between her and other contributors. For the sake of caution, Bogaevskii placed in the footnote the following information provided by Freidenberg herself:

This essay is an extract from a large work about the Odyssey that I wrote in 1922 before I became acquainted with the Japhetic theory of N. Ia. Marr and his article "Death as the Netherworld in the Mesopotamian-Aegean World," published in the Proceedings of the Academy of Sciences in 1924. However, I had only to pose the question of meaning and apply the genetic method in order to find myself smack in the midst of Marr's Paleontological Semantics. In this regard, it is instructive to see how an analysis of the plot from a non-Japhetic perspective turned out to be an illustration of the Japhetic analysis of names as found in the article by Marr referred to above, especially with regard to the formula Athena-Etana. ${ }^{28}$

In the above-mentioned articles (written two years after Freidenberg's essay), Marr suggested a common denomination for

${ }^{27}$ B. Bogaevskii, "Gomer i iafeticheskaia teoriia," Iazyk i literatura 4 (1929): 12, 13.

${ }^{28}$ Freidenberg, "The Plot Semantics of the Odyssey," SSL 27: 1 (1990-91): 22. Freidenberg is referring to Marr's "Smert'-preispodniaia v MesopotamskoEgeiskom mire," Doklady Akademii Nauk (DAN) 7 (1924); two other articles (also mentioned by Bogaevskii) in which Marr approached directly the famous Homer question are: "Towards the Interpretation of Homer's Name" ("K tolkovaniiu imeni Gomera"), DAN 7 (1924): 2-5; and "Denomination of the Etrurian God of Death 'Kalu' and the Terms 'Write', 'Sing', 'Devil', 'Poet', and 'Blindman,'” 183-94. 
'dwelling (house)', a derivative from the cosmic images of 'sky', 'earth', 'hell', as those were known to the archaic stages of the MesopotamianAegean cultures. He also surmised that in the 8th century B.C. the utterance 'Homer' did not point to an individual being (as the proper name does by modern standards). Rather, it provided a common denomination to a generic group of tribal performers-tricksters, who, like demonic and divine beings, were endowed with the power of working miracles, mimicking, and creating illusions through the magic of words. The polysemantic connotation was assigned to Homer's name from the planes of communal experience, all located outside the poetic contexts. Marr further endowed his hypothetical conjecture with the validity of incontestable truth. He stated that establishing the fact that the polysemantic connotation of the poet's name originated in the archaic culture of the collective, and not in poetry, completely invalidated the issue of individual authorship.

A classicist working with archaic pre-literate forms of folklore, Freidenberg also was not interested in the vexing problem of Homer's authorship. In "The Plot Semantics of the Odyssey" she treated the behavioral manifestations of the hero as basic compositional elements of epic plots. Of primary importance to the Iliad and the Odyssey, to the Greek and the Babylonian epos, was the hero's descent into the underworld and his adventures there: "A character who was solar in his earthly phase always had a corresponding hadean counterpart in the land of darkness, to which he descended in order to overcome the dark forces and attain the triumphant victory over them that marked his departure from the realm of death." 29 To the extent that behavioral manifestations (morphemes and formants, in Freidenberg's terminology) were stable elements in the tale, the plot semantics of different epic works were isomorphous as cultural forms. The purpose of the descent into the underworld had been always the same: either to free a deceased friend and to bring him back to the world of the living, or to question the deceased about the hero's own future destiny on earth. The genre structure of epic works was built on the same archaic scheme of winning the battle with death, but the plot structures "dressed it in different semantics." The archaic scheme which underlay the structure of characters as different as Odysseus, Aphrodite, and Heracles in one group, and their friends Elpenor, Adonis, and Theseus in the other, remained always the same. One can say therefore that "even before Homer the plot of the

29 "Plot Semantics of the Odyssey," 23. Freidenberg does not yet use the term "function." However, the explanation contained in the above quoted passage corresponds to Propp's functions 15-spatial transference between two kingdoms, guidance; 16-struggle; 18-victory; and 20-return. See Propp, Morphology of the Folktale, 50, 51, 53, 55-56. 
Odyssey, like Odysseus himself, possessed all the context and complexity of celestial and chthonic features, and it is only for this reason that now Hermes, now Apollo-Helios, now Poseidon reveal themselves to the hero in theophany. But none of them is a pra-image of Odysseus or of the plot about him in pure form even before Homer." 30

As a contributor to the group discussion of "Homer and Japhetic theory," Freidenberg interpreted authorship in the Odyssey and Iliad as an individual manifestation of collective memory. She expected a satisfactory answer to the controversy over the "Homeric question" to be found in the semantics of cultural forms. She associated the idea of the epic genre with the "vertical axis" of the structure, and discovered an archaic paleontological substratum of solar and chthonic myths at the base of epic poetry. Her article suggested a nonambiguous answer to Bogaevskii's question concerning the "reflected depth of epic poetry within the chronologically distinguishable stratifications of cultural background." Freidenberg located mythological morphemes, functions, and motifs along the horizontal dimension, in such a way that "within the chronologically distinguishable stratifications of cultural background," semantic elements of plots acquired new forms of "expression, presentation, and meaning." ${ }^{31}$ Freidenberg's approach did not completely meet the requirements of Marr's teachings, and with good reason she, as well as Bogaevskii, the editor of the collection Homer and the Japhetic Theory, claimed only the "elective affinities" of genetic and Japhetic methodologies.

The Homer issue of Language and Literature illustrated the unity of the Japhetidological position shared by the contributors, as well as the varieties and the range of interpretations individual researchers were allowed to manifest. The sector's reliance on Marr's typology of collective productive labor experience had been accepted as an established principle. $^{32}$ The contributors to the Homer Collection were all expected to accept the Marrist and Marxist monistic schema of the evolution of languages, culture, and speech-communications as unconditional truth.

Within the group of paleontologists, however, the predisposition towards a materialistic dialectical interpretation of evolutionary-developmental stages of experience varied from scholar to scholar. FrankKamenetskii had subtly altered Marr's typology of collective labor experience. Following Cassirer, he suggested that the primitive mentality should not be studied in the fixed categories of real existence, but that

30 Iazyk i literatura 4 (1929): 73.

31 "Expression, presentation, and meaning" are the basic terms of Cassirer's philosophy.

32 Nina Perlina, "From Historical Semantics to the Semantics of Cultural Forms," SSL 27: 1 (1990-91): 11. 
special "symbolic forms" of collective experience like those represented by and imprinted in myth, art, and language, rather than "laborproductive experience," are to be placed as the focus of the group study. ${ }^{33}$ His modification of the concept was met with enthusiasm, and three younger researchers of the group-Nikolai Petrovich Baranov, Al'tman, and Shmidt-following in his footsteps, presented articles, each of which was based on those of Cassirer's statements which FrankKamenetskii interpreted as comparable to Marr's general formulations. ${ }^{34}$

Cassirer was not the only contribution brought by the "mythical sector" in ILIaZV as a sacrifice on the altar of Marrism. Freidenberg and her colleagues utilized both Potebnia and Veselovskii and fused together the inner form with its syncretic manifestations in culture; they complemented the conclusions of these two great Russian philologists with the achievements of Herman Usener and other European scholars, and introduced to their treatment of culture ideas originating in Lévy-Bruhl. As a result, individual scholars, while being compelled to accept the doctrine of the New Teaching on Languages, brought about "Marrism with a human face."

The realization that she was unable to release herself from the fetters of Marrism-both a binding doctrine and a stimulating hypothetical supposition rolled into one-caused painful complications in Freidenberg's life. She could not imagine her life without the free exchange of ideas, but, at the same time, she was hurt by the clear realization that everything she produced as an individual scholar was added to the sum of Marr's theories. Of course, she enjoyed the atmosphere of the humanistic scholarship, intense academic exchange, and friendly environment of the erudite Japhetidologists. "But the tragedy which would ensue from it," she added in her cryptic manner, "was not yet clear to me" (3: 207). Freidenberg also believed that in spite of their amicable relations, her

33 Frank-Kamenetskii, "Pervobytnoe myshlenie," 117. Frank-Kamenetskii quotes the first edition of Cassirer's Sprache und Mythos. For an English translation, see Language and Myth, 8.

${ }^{34}$ Cf.: M. Al'tman, "K poetike Gomera," Iazyk i literatura, no. 4 (1929): 33-35, and Frank-Kamenetskii, "Rastitel'nost' i zemledelie," 165; N. Baranov, "Mana u Gomera" [Mana in Homer], ibid., 75-92. Baranov's explanation of "mana," "a mythical field of force, and atmosphere of potency which permeates everything," originated from the passage in Cassirer's Language and Myth, 63, which FrankKamenetskii explained in detail in "Pervobytnoe myshlenie." (Cf.: FrankKamenetskii, 111-20, and Cassirer, 62-67). In R. Shmidt's "Pervobytnoe myshlenie v obrazakh Iliady" [Primeval Thinking in the Images of the Iliad], "primeval thinking" was a conceptual borrowing as well as a quotation from both Cassirer and Frank-Kamenetskii (ibid., 93-109). 
male colleagues from the "mythical sector" treated her, a woman, as a secondary figure in the group; moreover, they were not willing to acknowledge the originality and the genuine significance of her professional contributions. ${ }^{35}$ In Freidenberg's diaries, the concessive meaning introduced by her "of course" and "but" addressed one big issue and many lesser ones as well.

The famous line from Archilochus which says that "the fox knows many things, but the hedgehog knows one big thing" certainly marks Freidenberg as a hedgehog. ${ }^{36}$ Obsessed with the feeling that "all that is to be found both within and outside myself is irreducible to itself alone, but is charged with meaning" (vse to, chto nakhoditsia vo mne $i$ vne menia, ne ischerpyvaetsia soboi, a imeet znachenie; $1: 1$ ), inexperienced in overcoming petty obstacles, and burdened with a rigorism which, from an ethical standpoint, she expected the people around her to demonstrate as well, Freidenberg did not feel comfortable with her Soviet co-workers. In the "mythical sector," she believed, colleagues frequently shared her ideas unscrupulously. Publicly she did not argue about her priorities, but in her memoirs she never failed to mention incidents of this type. A poignant suspicion that her innovative ideas were played down or unfairly appropriated had thwarted her professional relationship with Moisei Al'tman and Iosif Trotskii (Tronskii). ${ }^{37}$ As Freidenberg believed, they owed their approaches to her as-yet-unpublished studies (her master's thesis on the origin of the Greek novel, "The Plot Semantics of the Odyssey," and talks delivered for the sector), but failed to acknowledge this debt.

For their contributions "Toward a Poetics of Homer: What Does Japhetic Semantology Contribute to Homer Studies?" and "The Myth of Daphnis" Al'tman and Trotskii adapted Freidenberg's major idea that one and the same morpheme of the archaic plot finds different representations in cultural history and therefore serves simultaneously as a survival of archaic experiences and the incorporation of new ideas. The semantics of Thecla's name (dekla-palm tree) and the plot semantics of

${ }^{35}$ For examples of discriminatory treatment of female colleagues in the academic milieu, according to Freidenberg, see my "Primeval and Modern Mythologies in the Life of Ol'ga Mikhailovna Freidenberg," The Russian Review 51: 2 (1992): 190-92.

36 The quotation and the interpretation are borrowed from Isaiah Berlin's famous essay "The Hedgehog and the Fox," in his Russian Thinkers (New York: Penguin Books, 1978), 22.

${ }^{37}$ Following the arrest and execution of historian Isaak Matveevich Trotskii in 1935, his brother Iosif (1897-1970), and the wife of the latter, Mariia Lazarevna (1896-1987), were forced to change their last name to Tronskii. The Tronskiis were Freidenberg's colleagues for many years. 
the Odyssey had preserved cultural survivals of archaic myths of vegetation and of the battle between the celestial and chthonic elements, but the function of old semantic forms met the expectations of as-yet-unshaped, forthcoming contexts of Homer's and early Christian times. As Freidenberg demonstrated, the plot semantics of Thecla's story contained the notion of sainthood at the time when the institution of holy saints had not yet been introduced to culture.

Al'tman and Trotskii borrowed Freidenberg's system of arguments, but furnished it with their own textual contents. Without referring to "The Plot Semantics of the Odyssey " (whose idea he knew from Freidenberg's talk delivered for the sector), Al'tman also asserted that the plot of the Odyssey is focused on the voyages of two figuresOdysseus (the father) and Telemachos (his son), of which the latter duplicates the former, in such a way that the plot semantics of the father's journeys defines the semantics of the son's name. Odysseus is shown traveling and battling (mache-battle) far away (tele) from his native land, and this function of the hero's plot-line is reflected in the name of his son: Telemachos. ${ }^{38}$ Trotskii's article "The Myth of Daphnis" followed the heuristic principles of Freidenberg's master's thesis: in the motifs of the hero's miraculous escape, his journey in the sealed box (sarcophagus or coffin), his nurturing by the bees, Trotskii recognized the survivals and paraphernalia of vegetation myths. Al'tman's and Trotskii's borrowings from Freidenberg were camouflaged by the original topical issues of their studies. ${ }^{39}$ Freidenberg, however, looked upon the situation from the stance of one creating new ideas, and believed that her discoveries were plagiarized. And still, the word "tragedy" in her memoirs addressed something more substantial than disputed authorship or underestimated authority.

A problem far more serious than this disagreement with her colleagues was Freidenberg's philosophical conflict with Cassirer's teleological principle that underlay his understanding of cultural development. Her reservations about Cassirer concerned the validity of his principle which presupposed that "the whole of human culture has a common evolutionary origin in human experience" and suggested the "teleological unity of function in achieving a common harmony for any given historical culture as well as for the culture of humanity as a

${ }^{38} \mathrm{M} . \mathrm{Al}^{\prime}$ tman, "K poetike Gomera," 42-57.

${ }^{39}$ I. M. Trotskii, "Mif o Dafnise," Iazyk i literatura 8 (1932): 205-27. For references to Freidenberg, in which her Master's thesis is not mentioned, but only her "Myth of Joseph the Beautiful" and "Blindman over a Precipice" are named, see 218, 224. 
whole." ${ }^{40}$ The disagreement with Cassirer's philosophy was never formulated as an issue for discussion in Freidenberg's articles. In her memoirs, however, she wrote about her infatuation with Oswald Spengler's Gestalt und Wirklichkeit and Welthistorischen Perspectiven; her interest was so serious that she asked her uncle, who lived in Munich at that time, to obtain Spengler's address for her; she sent Spengler a letter "written in a very bad English," but received no answer (3: 214). Spengler's Morphology of Culture was immune to teleology. Unlike Cassirer (his philosophical antipode), Spengler did not seek to designate a common function for the whole of human culture, and his interpretation of cultural phenomena contained no indication of a teleological restructuring of heterogeneous cultural elements into a homogenous whole. Freidenberg included a well-balanced critical overview of Spengler's concepts in the introductory chapter to The Poetics of Plot and Genre. ${ }^{41}$ However, for a scholar working in a Soviet institute for scientific research, epistemological conflicts with the "bourgeois philosophical ideas" represented by Cassirer, Spengler, Boas, and many others likewise bore little ideological contagion. The matter concerning the rightness of Marr's teaching, however, was of quite a different ilk, and this conflict could most deservedly be called "the tragedy" in the life of O. M. Freidenberg.

40 David Bidney, "The Philosophical Anthropology of Ernst Cassirer and its Significance in Relation to the History of Anthropological Thought," in The Philosophy of Ernst Cassirer, 542.

41 Poetika siuzheta, 26-27. 
Chapter 5

Freidenberg's Semantic Paleontology and the History of Folklore

\section{A. The Collective Study of the Plot of Tristan and Iseult}

$\mathbf{F}$ reidenberg was never allowed to air her serious reservations concerning Marr's evolutionary approach to the paleontology of culture. Marr's stage/structure opposition and the postulate that the cultural and anthropological process is determined by the relations of production were treated as inviolable commandments in Soviet scholarship. In addition, every Soviet scholar working in the humanities had to accept as a prescript the axiomatic statement that the evolution of the relations of production is reflected in the phenomena of superstructure: languages and ideologies. ${ }^{1}$ Unlike Marr, at the center of her studies Freidenberg placed the capacity of human consciousness for selfreflection. From her analysis of the architectural semantics of the puppet theater, it followed that rather than providing additional illustrations for the theory of reflection, she would trace reconstitutions of the general "signification of meaning," and that rather than proceeding from matter or a material basis, she would instead take as her point of departure a law governing regularities of consciousness. Reliance on Cassirer enabled her to place language-the system of semantic connotations and meanings-rather than the relations of production at the base of her cultural studies. But in order to shield her studies from evolutionary schemata incompatible with her genetic approach, Freidenberg needed typological models and fixed formulae capable of pointing to how the morphemes of archaic myths worked to bring about constituents of newer cultures. She had to find a denominator which would enable her to distinguish between new and old forms of communal representations and worldviews: to characterize, let us say, archaic

\footnotetext{
${ }^{1}$ This thesis, originating from Historical Materialism, was built into Marrism mainly due to the efforts of politically oriented linguists from the Iazykofront. A thorough analysis of Marr's own encounter with this philosophical dictum demands closer investigation, which is beyond the scope of my study.
} 
folklore as "a specificum," something special by contrast to religion and cult, or to discriminate between literature and oral poetic lore at the level of the semantics of different cultural forms. ${ }^{2}$ This "specificum," Freidenberg presumed, would locate for each type of communal enactment a fixed place and time in the life of the collective. Instead of Marr's syncreticism, Freidenberg's specificum introduced "quality" to semantic paleontology. She treated quality as a characteristic which belongs to an individual phenomenon and helps to make it what it is, in distinction to all other occurrences. Through identification of a new quality one aspect of communal worldviews becomes distinguishable from another. While Freidenberg could go so far in her paleontological approaches as to ask directly "On what basis is this newness determined," the "correct" answer did not allow her to step over the prescribed bounds of Marrism and Marxism. Thus, stubborn rigorist that she was, Freidenberg was compelled to accept the following formulation in her paper:

Folklore enters the verbal arts organically as one of the elements of its worldview, which provides the basis for the creation of any given work. The proportion between folkloric and nonfolkloric elements is determined by the stage of cognition, conditioned by the relationships of production in the concrete society, i. e., the stage of class struggle.

Фольклор органически входит в литературу в качестве одного из элементов мировоззрения, на базе которого создается и данное литературное произведение. Пропорция между фольклорными и не-фольклорными элементами определяется стадией мышления, обусловленного производственными отношениями конкретного общества, т.е. стадией классовой борьбы. ${ }^{3}$

Rereading her meta-textual observation in The Race of Life, one realizes that Freidenberg experienced this intrusion of Marrism into the territory of her cultural studies as "the real tragedy." To mitigate the damage, she opted not to stipulate the border-line dividing her genetic method from paleontological approaches determined by socio-economic foundations. Her concentration on typological models made comparisons of identical plot lines and motifs in the works of individual poets of the same epoch irrelevant to the main direction of her analyses. In this precarious situation, Freidenberg's typology clothed her genetic methods in

${ }^{2}$ O. Freidenberg, "Fol'klor u Aristofana (Tesmoferiazusy)," in Sergeiu Fedorovichu Ol'denburgu $k$ piatidesiatiletiiu nauchno-obshchestvennoi deiatel'nosti: 1882-1932. Sbornik statei (Leningrad: AN SSSR, 1934), 557, 560.

${ }^{3}$ Ibid., 560 . 
Marrist garb and made them acceptable to his teachings inasmuch as an interest in typological models characterized his own excursus into the area of verbal arts. Freidenberg admitted only pre-literate, oral forms of verbal arts into her studies. Within her own methodological framework, stage/structure relations were rectified in the sense that the archaic semantics of the plots were recognized as archetypes for further modifications of collective consciousness. Therefore, at first glance, her views could simply be mistaken for a fragment of the Marrist perspective. Although Freidenberg was compelled to compromise with Marrism, her chosen perspective still allowed her to trace invariants of individual plots through the mythologems of different cultures. The approach enabled her to modify Marr's theory of four elements and semantic clusters into a clearly shaped "plot of plots." Those of Freidenberg's colleagues in the mythical sector who felt that their research goals were limited by the rigidity of Marrist schemata accepted her alternative with enthusiasm.

The second collective study undertaken by the "mythical sector" centered around the plot of Tristan and Iseult, and Marr himself insisted that Freidenberg take upon herself the responsibilities of editor-in-chief. The study aimed to specify and develop some of the hypotheses advanced by Marr as early as 1925-26 in his seminal studies "From a Journey to the European Japhetites" and "Ishtar: From the Goddess of Matriarchal Afro-Eurasia to the Love Heroine of Feudal Europe." Indicative of her position vis-à-vis Marr, Freidenberg provided an indepth analysis of his old work which focused on glottogony and logogenesis and did not yet bear the mark of his later infatuation with dialectical and historical materialism.

In his paper on Ishtar and in his report on his 1922-23 trip abroad (Berlin-Paris-Bilbao) presented to the Russian Academy of Sciences, Marr used the term "European Japhetites" to refer to contemporary Basques and their spoken language, as well as the hypothetical language of the Etruscans, which had been preserved in fragments obtainable from monuments of material culture. As usual, he treated several vexing problems in a manner which allowed for more than just a few discrete interpretations. On the other hand, Freidenberg's clearly formulated outline for the proposed study on Tristan and Iseult provided the necessary specifications and drew yet another line of demarcation between her own treatment of cultural history and that of Marr.

In both papers Marr addressed the issue of the origins of voiced speech, stating explicitly that it does not suffice to take into account

4 Marr, "Iz poezdki," 1-46. For the complete text of Marr's paper "Ishtar' (ot bogini matriarkhal'noi Afrevrazii do geroini liubvi feodal'noi Evropy)," see Iafeticheskii sbornik 5 (1927): 108-79. 
solely the ordinary phonetics and morphology which contributed to the formation of the words and grammar of different languages. "There exist a phonetics and morphology of the idea-bearing or semantic order, without which the human race would not have had in its possession the available treasuries of words which came about as a result of ideational disassociation and phonetic-morphological differentiation" ("Существует фонетика и морфология идееносного или семантического характера, без которых человечество не распологало бы наличным богатством слов, получившихся в результате идейной диссоциации и фонетико-морфологической дифференциации"). ${ }^{5}$ Primeval human collectives (hordes, tribes, ethnic units) had come to life gradually; they were distanced and isolated from each other territorially; their communicative word-signals differed from group to group vocally, yet the regularities of the glottogonic process were the same in all primordial collectives. However, in Marr's opinion, one should not exclude the possibility that every Japhetic tribe, possessed as it was of its own individual totem for its collective body, had, in turn, associated its own "proper name" with that combination of sounds that formed the name of this tribal god. For a given tribe, this word was its totem, its own god. "It would not be wrong to believe that John the Evangelist draws not from scholastic speculations, but from living tradition concerning the actual pre-historical state of affairs which he describes as 'In the beginning was the Word, and the Word was God."'6 The historical localization of different tribes, their migration, merging, dispersal-all of these processes were accompanied by the crossbreeding, hybridization, and creolization of their spoken languages. Therefore residual forms of archaic perceptions had been preserved in the vocabulary of ethnic groups which formed as collectives in later epochs, and in territories unknown to their "paleontological" progenitors. Vestiges of the greatest proto-historical Japhetic deity, HEAVEN-WATER, which was held to be both Chaos and the life-giving female element, can be found in the female image of Ocean, who was also represented as the Great Mother of god. Echoes of this totemistic notion can be recognized in certain myths of Europe and Zeus, in mythologems of the Homeric and pan-Hellenistic epos, and finally, in the well-known romance Tristan and Iseult. ${ }^{7}$ In the myths of the Phoenician and Babylonian cycles, Astarte and Ishtar represented the goddesses of Matriarchal Afro-Eurasia, while Iseult, the

\footnotetext{
5 Marr, "Iz poezdki," 51.

${ }^{6}$ Ibid., 49-50.

${ }^{7}$ Ibid., 36, 47-48. Marr acknowledged the priority of Gaston Paris's supposition that Tristan represents the sun transformed into the love hero.
} 
heroine of the feudal love romance from the French or English Middle Ages, represented one of Ishtar's stage equivalents. ${ }^{8}$

In order to provide a detailed overview of Marr's hypothesis, according to which Ishtar "turned out to be Iseult's ancestor, her namesake," Freidenberg and other members of the group chose "the plot of plots" about Tristan and Iseult by Joseph Bédier, and juxtaposed this masterplot with its various ethnic and regional transcriptions, as well as with their common archaic mythologem as it was known from its different historical epochs. Freidenberg and Frank-Kamenetskii, the co-editors of the collection, delineated the perspective and the main goals sought by the study. They distributed the material among their colleagues so that every member of the group received a sampling of sources that provided either a contrastive or a complementary pair to the medieval romance. Expanding on Marr's assertion about the Ishtar-Iseult typological identity, Freidenberg insisted that when placed along synchronic and diachronic axes the story of Tristan and Iseult and "the plot that [was] available for implementation under medieval feudalism [was] but the latest link in a long chain of transformations brought about by changes in the social structure." ${ }^{9}$ After the medieval "plot of plots" had been located within the synchronically and diachronically distinguishable stratifications, the group traced out "the entire series of plot transformations reflecting specific phases in the development of thought according to changes in socioeconomic structure."10 The transformation of the plot and the history of its development were traced through the reconstitution of components within an archaic semantic cluster. This cluster reflected the thinking of the "cosmic" stage (myshlenie kosmicheskoi stadii) and corresponded to the "cosmic plot structure" (kosmicheskaia fabula) of the most archaic archetypal mythologems of the different ethnic and geographical regions.

Freidenberg's introductory article was followed by A. A. Smirnov's summation of the hypothetical prototypal Celtic version of the plot. In the second of the two papers she contributed to the collection, Freidenberg investigated the different stage equivalents for "the plot of plots" within the mythologems of the Aegean region of the Mediterranean sea; Frank-Kamenetskii traced analogies to the same plot in the Biblical poetry, while for his part Vasilii Struve went from Iseult-

\footnotetext{
${ }^{8}$ N. Marr, "Ishtar'," 113; Freidenberg, "Tselevaia ustanovka kollektivnoi raboty nad siuzhetom Tristana $i$ Isol'dy," Tristan $i$ Isol'da: Ot geroini liubvi feodal'noi Evropy do bogini matriarkhal'noi Afrevrazii (Leningrad: AN SSSR, 1932), 3, 4. Translated as "The Main Goals in the Collective Study of the Plot of Tristan and Iseult," SSL 27: 1 (1990-91): 54-66.

${ }^{9}$ Freidenberg, "Main Goals," 56.

10 Ibid.
} 
Ishtar back to the most archaic myths of the Babylonian and Egyptian pantheon (Astarte, the deities of the sea and the harvest, and the nine mighty gods). ${ }^{11}$ Reconstitutions of the cosmic fabula and parallels to the leading plot lines were found in Mordovian, Caucasian, and Russian folk tales (B. Latynin, A. Endiukovskii, M. Tikhaia-Tsereteli, N. Driagin, T. Passek), as well as in the Georgian medieval poem Abesalom and Ether (K. Dondua). ${ }^{12}$ Additional linguistic sources for paleontological analyses were provided by Germanic eponyms and toponyms (V. Brim). The plot constructions and motifs of the single battle and the love triangle were traced through the composition of Tristan and Iseult and other medieval romances (B. Kazanskii). ${ }^{13}$

The Collective Study of Tristan and Iseult treated the so-called "cosmic fabula" of primeval myths and religious concepts as a multinuclear, discrete set of homologous forms. The contributors stated that cosmic, zoomorphic, vegetative, and anthropomorphic renditions of the same archetype were known to different ethnic groups and in different centers (nuclei), independently of each other. As the archetypal antinomic identity remained everywhere the same, structural transformations of the archetype illustrated the dynamics of cultural development in its relation to the solidifying power of cultural memory and tradition. At the source of the diversity among cultural configurations was the distinction between the paleontological semantics (the cultural semantics of symbolic forms) and the historical semantics of poetic forms. While tracing the reverse process from Iseult back to Ishtar, the Collective Study made clear the social genesis of the mythological masterplot and followed its transmittal through various folklore genres, such as the Russian Wondertale about Vasilisa-the Beautiful and Mordovian legends of serpent-slayers. Survivals of matriarchal and patriarchal social

11 A. A. Smirnov, "Roman o Tristane i Isol'de po kel'tskim istochnikam," Tristan i Isol'da, 17-36; O. Freidenberg, "Siuzhet Tristana i Isol'dy v mifologemakh Egeiskogo otrezka Sredizemnomor'ia," ibid., 91-114, translated as "The Plot of Tristan and Iseult in the Mythologems of the Aegean Region of the Mediterranean Sea," SSL 27: 1 (1990-91): 67-87; I. G. Frank-Kamenetskii, "Ishtar'-Isol'da v bibleiskoi poezii," Tristan $i$ Isol'da, 71-89; V. V. Struve, "Ishtar'-Isol'da v drevne-vostochnoi mifologii," ibid., 49-70.

12 B. A. Latynin, "Arkhaicheskii ekvivalent mifa o Tristane i Isol'de v mordovskom fol'klore," Tristan i Isol'da, 215-26; A. G. Endiukovskii, "Siuzhet Tristana i Isol'dy v mordovskom fol'klore," ibid., 227-60; M. G. TikhaiaTsereteli, "Zhenskii obraz mzeeunafav gruzinskikh skazok," ibid., 137-74; N. M. Driagin, "Liubovnye motivy nartovskogo eposa gortsev Severnogo Kavkaza," ibid., 183-99; T. S. Passek, "Motivy Tristana i Isol'dy po materialam russkoi skazki," ibid., 201-14; K. D. Dondua, “Abesalom i Eter," ibid., 175-82.

13 V. A. Brim, "Ishtar'-Isol'da po germanskim materialam," ibid., 37-47; B. V. Kazanskii, “Antichnye aspekty siuzheta Tristana i Isol'dy," ibid., 115-35. 
structures and relations of production were not imposed directly on the poetics of medieval folklore. Rather, the socioeconomic level of the paleontological analysis was substituted by the semantics of plot structures and genres, and the dialectics of plot/genre relations were worked out on interdependent planes of collective experiences. The subject of Tristan and Iseult was summarized as a typical medieval story of the hero's fight on behalf of his suzerain, as a tale about love, separation, death, and poetic reunification in love, but the realistic motifs of this romance absorbed the cardinal, structurally meaningful components of the archaic collective worldviews. Everything that facilitated the communication of the content-bearing components at the mythological level was rendered through the poetic forms of the medieval romance. Thus the golden hair of Iseult, her healing skills, her falling in love and union with Tristan aboard a vessel at sea on a dark night, as well as the beautiful rose bush or the honeysuckle that grew over the graves of the lovers-all these elements of the medieval love story reflected the heroes' connection with sun, water, sky, and primordial chaos, with archaic mythological entities which, before they became known as the fixed images and standing epithets of the medieval romance, entered into symbolic representations of life and death, cosmogony, vegetation, and zoomorphism. ${ }^{14}$ Thus the Collective Study made a step forward beyond paleontological semantics, suggesting an additional discussion of the "paleontological morphology of myth and plot." 15

The volume prepared by Freidenberg and Frank-Kamenetskii summed up a two-year collective effort to study of myth and folklore, but by the time the book was published in 1932, new political directives were imposed on the Soviet humanities. The change which took place in the official ideology hardly boded well for a favorable reception of the work. Prior to the publication of the book, the Communist Party "had proven" that folklore stems from the creativity of the working masses. This political statement was fraught with serious consequences for those scholars whose subject of study was the love stories once told in the households of medieval kings. Consequently, Marr tried to dissociate himself from the work whose main goals he had once approved. In 1929 he invested Freidenberg with full authority and power: "You have to take the guidance of the group upon yourself. We need a literary scholar. I think that only you are a real expert in literature. Frank-Kamenetskii is a philosopher; Bogaevskii an archeologist. You can organize the work better than anyone else. I entrust it to you"-those were Marr's own words, Freidenberg wrote (4: 179). Three years later, in June 1932, she

\footnotetext{
${ }^{14}$ Freidenberg, "The Plot of Tristan and Iseult," 69, 77-78.

15 Frank-Kamenetskii, "Itogi kollektivnoi raboty nad siuzhetom Tristana i Isol'dy," Tristan i Isol'da, 273.
} 
felt "indignant with Marr who is so cringing that he decided to renounce Tristan publicly and to criticize my work" (5: 33). However, Marr's leading position in the Institute to which the mythical sector belonged and the contributors' laudatory references to his ideas protected the collection from criticism and saved the members of the group from the purges.

\section{B. The Discussion "What is Folklore": Freidenberg, Zhirmunskii, Azadovskii}

During the early period of Freidenberg's professional career, the term "interdisciplinary studies" was not yet used, and intercultural approaches to the humanities were implemented through "complex and systemic methodologies," through various "team-group methods" (kompleksnye, sistemnye, brigadno-gruppovye metody), and, of course, through Japhetidology and Semantic Paleontology. Since the cultural politics of Bolshevism combined secularism, proletarian internationalism, and the Socialist enlightenment of the working people, the government furthered ethnographic studies of culturally and economically underdeveloped societies and colonized nations, and promoted the ethnolinguistics of oral cultures. At the same time, traditional folklore was labeled as an "ideological byproduct of the backward, counterrevolutionary classes," and "the belief that folklore reflected the ideology of the ruling classes gave rise to a strongly negative attitude toward it in literary circles." 16 Characteristically for the professional lexicon of the era, in 1918-22 the Department of Social Sciences (Fakul'tet obshchestvennykh nauk, FON) and the Geographical Institute of Petrograd University had numerous courses in ethnography, ethnology, and paleontology of culture, but no folklore studies in their curricula. ${ }^{17}$ In his collection Folklore, Nationalism, and Politics, Felix Oinas rightly absolved many prominent Soviet folklorists of blame for their desire to hide their professional identity under the guise of general philological studies. During the 1920s and early 1930s, Vladimir Propp approached Russian folk tales through taxonomy and morphological analyses and published his works under the aegis of the State Institute of the History of the Arts; Dmitrii Zelenin (1878-1954), an acknowledged folklorist and ethnographer, camouflaged his interest in folklore as a study of pre-his-

\footnotetext{
${ }^{16}$ Felix Oinas, "The Political Uses and Themes of Folklore in the Soviet Union," in Folklore, Nationalism, and Politics, ed. F. Oinas (Columbus, OH: Slavica Publishers, 1978), 77. See also his "The Problem of the Aristocratic Origin of Russian Byliny," Slavic Review 30 (1971): 513-22, and "Folklore and Politics in the Soviet Union," ibid., 32 (1973): 46-47.

17 See chapters "Kak ia stala etnografom" and "S kotomkoi za plechami" in N. I. Gagentorn, Memoria, 50-53, 257-81.
} 
toric lore and ethnology. Zelenin made full use of his affiliations with Marr and with the State Academy of the History of Material Culture (GAIMK), but during 1917-1933 he avoided the word "folklore" in his writings. ${ }^{18}$ Ivan Ivanovich Tolstoi published his folklore studies under the guise of Classical Philology. Only after the abstract of his article "The Language of the Folk Tale in Greek Literature" was accepted as a Soviet contribution to the prestigious Italian Festschrift in honor of Felice Ramorino did Tolstoi submit this work to the Soviet collection Poetic Folklore. ${ }^{19}$ Viktor Zhirmunskii promoted folklore as one component of ethnolinguistics and comparative studies. ${ }^{20}$ Freidenberg succeeded in finding a niche for folklore in the history of mythology and Japhetic studies. As she described it, "We, the Japhetidologists, were the first advocates of folklore, but we were whipped for it. Later, when folklore came into fashion, its former adversaries-Azadovskii, Zhirmunskii, and Tolstoi threw themselves into it" (5: 3).

Of course, Freidenberg knew that she unjustly placed I. I. Tolstoi and M. K. Azadovskii among the enemies of folklore. In the very same volume of her Race of Life she quotes the amicable inscriptions which she and Azadovskii wrote on the papers that they proffered to each other as gifts. Following the pattern of a Spanish romancero, and playing on Azadovskii's name (Mark Azadovskii-King Mark, Iseult's husband and Tristan's suzerain) to enhance the effect of parodic imitation, they developed a charming dialogue in verse. Freidenberg autographed her Tristan and Iseult collection with the quatrain:

I fear that Mark, becoming a wild beast enkindled with jealousy, May put right his family affairs with me

And kill Tristan and Iseult

With his review.

Дрожу, чтоб Марк, от ревности зверея,

На мне семейных счетов не сводил,

И чтобы он рецензией своею

${ }^{18}$ On Zelenin's contributions to ethnography, folklore, dialectology, and cultural anthropology, see Problemy slavianskoi etnografii. K 100-letiiu so dnia rozhdeniia chlena-korrespondenta AN SSSR D. K. Zelenina, ed. A. Baiburin, K. Chistov (Leningrad: Nauka, 1979).

${ }^{19}$ I. I. Tolstoi, "Iazyk skazki v grecheskoi literature," Khudozhestvennyi fol'klor 4-5 (1929): 82-93; for the abstract of the paper "Une survivance de language des contes populaires chez Herodote," see Raccolta di scritti in onore di Felice Ramorino (Milano, 1928), 376-80.

${ }^{20}$ M. Tronskaia, "V. M. Zhirmunskii," introduction to Ocherki po istorii klassicheskoi nemetskoi literatury by V. M. Zhirmunskii (Leningrad: Khudozhestvennaia literatura, 1972), 3-11. 
Тристана и Изольды не убил. (5: 29)

Freidenberg's biased remark about Azadovskii's hostility to folklore is, undoubtedly, a by-product of the ideological situation in the 1930 s, described in her diaries as

the time of the reinforcement of Stalinism, the demolishing of the peasantry, the "dizzying from success" [golovokruzhenie ot uspekhov]. The era of Soviet Fascism was coming into being, but we still accepted it as a continuation of the revolution with its thirst for destruction. We still did not know who Stalin really was and believed that there was some program behind him. (4: 156)

Thus, implicitly, Azadovskii's "hostility" to folklore illustrated his proclivity to conformism rather than ignorance about the significance of folklore studies. To illustrate what she actually meant, Freidenberg entered into The Race of Life a "bibliographical rarity": a set of abstracts (her own and Zhirmunskii's) for the discussion "What is Folklore," which was organized by Mark Azadovskii in June 1931 in IRK (5: 3-10). In his summary, Zhirmunskii treated poetic folklore among the "residual survivals of the material and spiritual culture of the socially and historically backward classes (peasantry and petit bourgeois)."

Under the cultural hegemony of the ruling classes, in developed class society (especially in capitalist society) an ongoing process of importing culture from above takes place, the process of the "descent" of artistic values with their further social transformation. $(5: 4,5)$

Since in modern industrial societies the objects of folk production are not original, but imitative artifacts, it followed that the study of folklore could not be legitimized as an autonomous discipline. Folklore studies are to be incorporated into ethnography and ethnology, or else conducted as one component of the paleontology of culture. The history of folklore is to be built into comparative literature, or else limited to collecting old curiosities, so-called "living relics."

In this abstract, Zhirmunskii tried to meet the requirements of Stalin's political dicta-his "six conditions and tasks necessary for the building of Socialism in the USSR." This becomes evident from the strongly politicized terminology: "rudimentary survivals" rather than "vestiges of cultural experience," "the folklore of the declasseé," "the artistic production of ideologically narrow-minded workers." Zhirmunskii also stated that "in a socialist classless society, as cultural backwardness and differences between the city and the village are 
removed on the basis of collectivization and the industrialization of agriculture, the problem of folklore is eliminated" (5: 6).

Freidenberg countered Zhirmunskii with her invariable oppositions: "doliteratura/literatura" and "classless/class society." "We have to distinguish," she insisted, "between that stage in the development of literature that begins in the class society and the preliterary stage of the classless society. Folklore is, in fact, the ideological production of a classless society, which is present either in its pure or obliterated form as ideological artifacts of class society" (5: 7). From this point of view, "the folklore of the working class" ( $r a b o c h i i$ fol'klor) is as much a contradiction in terms as "socialist religion"; it does not exist, for the proletariat cannot produce classless artifacts. Rather than a "rudimentary survival," folklore represents a natural period of cultural development. While "pushing down" obsolete artifacts from above onto the popular culture, the ruling classes cultivate "olden times and old folklore traditions (i.e., reactionary romanticism)." The ruling classes dump the refuse of their cultural values into the rural areas, where they disseminate their trite artifacts, the typical "class literature of the petit bourgeois," among the peasants. From the paleontological point of view, Freidenberg insisted, "class literature" represents an outdated and obstinate ideological experience: religious books and old religious rites, all introduced as "folklore." Thus, unless a new consciousness and new, socialist standards of life are put into effect, folklore, this specific form of collective worldview, cannot be eliminated (5: 7-10).

As Freidenberg herself admitted, she made many of these statements in the heat of polemics, and she too paid her tribute to the political jargon of the 1930s- "bolshevichila" (harangued Bolshevism), as her caustic colleague Solomon Lur'e used to say. ${ }^{21}$ It is also quite apparent that, although their theoretical platforms were different, both Zhirmunskii and Freidenberg were trying to save folklore: he by incorporating it into ethnography and cultural anthropology, and she by placing it under the umbrella of semantic paleontology.

By relating folklore to the creative activity of classless societies, Freidenberg attempted to draw a line of demarcation between true oral lore and the avalanche of cheap ideological products manufactured

${ }^{21}$ Solomon Iakovlevich Lur'e (1890-1964), historian of Greek antiquity, one of Zhebelev's students and Freidenberg's colleague. During the years of stagnation, the biography of Solomon Lur'e was compiled by his son Iakov (an acknowledged Soviet medievalist from Leningrad) and published abroad as an "extract" from the archive of Solomon's sister Bogdana Iakovlevna (died in New York in 1981). See B. Ia. Koprzhiva-Lur'e, Istoriia odnoi zhizni (Paris: Atheneum, 1987). The publication provides a complementary and, in many instances, polemical counterpart to Freidenberg's memoirs. 
during the Stalin era as the "revolutionary folklore of the working masses." And her unwillingness to accept the very idea of contemporary folklore was disputed by Azadovskii. In the early 1920s Azadovskii conducted fieldwork in Siberia, and in 1934 he became an editor of the journal Soviet Folklore, to which he contributed numerous studies. ${ }^{22}$ Two of his surveys discussed the correlation between Marr's semantic paleontology and contemporary folklore studies: the first, "To the Memory of N. Ia. Marr" (1934), came out in 1936; and the second, "Twenty Years of Soviet Folkloristics" (1937), in 1939. ${ }^{23}$

In a preface to the first issue of Soviet Folklore, Azadovskii argued that folklore is not only connected with the past, but that it always reflects contemporary views of the people as well. ${ }^{24}$ Unfortunately, this reasonable claim, made by an erudite editor who treated folklore as an ongoing cultural activity of the people, helped turn his new periodical into a mouthpiece of political indoctrination: themes of the Civil War in the songs and legends of different nationalities, peasants' songs on Lenin, Stalin, and Lavrentii Beriia began to dominate in every issue. Azadovskii stressed the connection between the poetic structures of folklore and the social life of the people; he demonstrated that the specificity of the historical time and of the local region always leaves an imprint on the aesthetic features of the artifacts. As a scholar who collected new regional songs, legends, and tales, Azadovskii was also interested in the individual characteristics of folk songs and in the personalities of the performers and song-makers; therefore he did not feel comfortable with the typically "Japhetic" emphasis on the oneness and unity of typological development in culture. ${ }^{25}$

22 In 1918-21 Azadovskii collected funeral laments of Siberian female keeners and in 1922 published a thorough analytical study Lenskie prichitaniia (Chita, 1922). During the Civil War he served in the Ministry of Education in Siberia, under Kolchak's government, and later lived in constant fear of being charged by the GPU with counter-revolutionary activities.

23 M. K. Azadovskii, "Pamiati N. Ia. Marra," Sovetskii folklor 2-3 (1936): 5-20; "Sovetskaia fol'kloristika za dvadtsat' let," ibid., 6 (1939): 3-53. It is worth mentioning that Marr died in 1934, thus, "In Memoriam" as well as Azadovskii's anniversary overview of Soviet folklore studies each came out with a two-year delay - a fact that clearly reflects the instability of the ideological status of folklore in the $1930 \mathrm{~s}$.

24 Sovetskii fol'klor 1 (1934): 3.

25 For a thorough discussion of how the fieldwork of Soviet folklorists served both scholarly and political goals, see F. Oinas, ed., Folklore, Nationalism, and Politics. On the connections of folklore with contemporary life, see M. K. Azadovskii, Istoriia russkoi fol'kloristiki (Moscow: Gosudarstvennoe uchebnopedagogicheskoe izdatel'stvo, 1958-63), 1: 375-83; 2: 112-17. A quarterly journal by the Russian Geographical Society, Times of Yore (Zhivaia starina, Saint 
According to Azadovskii, Marr, who "was not a folklorist in the exact sense of this word," used folklore as a source material to illustrate his own theories. Azadovskii did not pay mere lipservice to Marr when acknowledging that folklore studies gained from adapting the general postulates of Japhetic theory, but he did not fail to mention that as a methodological aid Marr's ideas remained too broad to meet the needs of historians of folklore. ${ }^{26}$ The works produced by the PaleontologistsMarr's own "Ishtar (From the Goddess of Matriachal Afro-Eurasia to the Love Heroine of Feudal Europe)" and the Tristan and Iseult collection edited by Freidenberg and Frank-Kamenetskii-advanced daring speculative interpretations, but hardly offered secure guidelines to those involved in textual analyses of folklore sources. ${ }^{27}$ For whatever reason, Azadovskii refused to see any difference between Marr's general overview of human culture and those far more precise approaches which Freidenberg and other contributors to the Tristan collection introduced into their study.

Contemporary studies of oral lore, Azadovskii continued, should not be limited to reconstitutions of mythological plots and transformations of semantic clusters through different stages of social development. The observations which follow from an analysis of the semantics of myth (Freidenberg's collection) can hardly suffice for all the needs of those working with folklore material. Freidenberg's definitions- "literature is a product of a class society, but before becoming what it is, it passed through a stage that we are familiar with in the form of folklore" and "folklore itself had a long path of historical development"-cannot satisfy those studying particular forms and individual artifacts of oral lore. $^{28}$ The dissimilarities between folklore and literature cannot be reduced to the antinomy "preliterature/literature," for this formula renders folklore only as an archaic substratum and does not take into ac-

Petersburg, 1890-1916), whose active contributors were Marr and S. F. Ol'denburg, was revived in 1994, and its editorial bears the title "Russian Folklore Studies at the Gates of Freedom." See Boris Putilov, "Russkaia fol'kloristika u vrat svobody," Zhivaia starina. Zhurnal o russkom fol'klore $i$ traditsionnoi kul'ture 1 (1994): 4-7.

${ }^{26}$ For Azadovskii's treatment of Marr's theories and of the situation in Soviet folklore studies, see his contributions to Sovetskii fol'klor: "Pamiati N. Ia. Marra," 5-20 ; "Sovetskaia fol'kloristika," 3-53, of which pp. 3-4, 41-48 provide an analysis of Marr's theories, and pp. 42-43 offer reservations about Freidenberg's methods.

${ }^{27}$ Azadovskii, "Pamiati N. Ia. Marra," 6-14.

${ }^{28}$ Azadovskii referred to Freidenberg's introduction to the collective study of the plot of Tristan and Iseult, here quoted from SSL 27: 1 (1990-91): 54, 57. For Azadovskii's critique of the collection, see his "Pamiati N. Ia. Marra," 6, 8, 1415. 
count its close connection with contemporary reality. A new philological discipline, "Japhetic folkloristics" (iafeticheskaia fol'kloristika), had yet to find subjects and methods different from those of the genetic and sociological approaches of semantic paleontology.

Freidenberg acknowledged that Azadovskii's "In Memoriam" was "the most comprehensive overview of Marr's theory," but believed that in it he diminished the significance of her own contributions to the theory of folklore. She was disappointed with Azadovskii's inability to understand the originality of her approaches: unlike other Marrists, she distinguished vigorously between the preliterature which belonged to the era of exclusively oral culture and the oral poetry composed in the epoch of written cultures. As Freidenberg reiterated throughout her works, instead of addressing the social elite in a class society, the oral compositions of ancient times expressed the collective feelings of their communities, and ancient Greek literature came about as the result of the reconstitution of what this archaic communal mode of poetic thinking (archaic folklore) used to be. Within this line of development, the early Greek literature which had preserved all the pertinent features of this process of becoming, of energeia, differed fundamentally from ergon-from the final achievements of European classicism. Freidenberg believed that her methods described ancient folklore as a specificum, as a qualitatively new category of collective worldview, fundamentally different from other types of social Weltanschauungen. Since she did not mean to transpose her methods onto the aesthetic phenomena and artifacts of the written cultures of modernity, Freidenberg was reluctant to accept Azadovskii's criticism as justifiable. By 1939, her partial disagreement with Azadovskii ceased to be a purely methodological conflict. In 1939 his old survey "Twenty Years of Soviet Folkloristics" acquired new political overtones and, in tune with the times, required that Soviet scholars "turn their faces to the working people"-an injunction that could lead to the persecution of those who once contributed to the study of chivalric medieval romance. An inveterate rigorist, Freidenberg charged Azadovskii with perfidious opportunism, and from 1939 on, they were to remain "friends and enemies at the same time" (5: 3). 
Chapter 6

Freidenberg and the Formalists: The Broken Connection

\section{A. A Similarity of Macrostructures and Dissimilarity of Microstructures}

$\mathbf{T}$

hose works written by Freidenberg between the completion of her master's thesis and the publication of her doctoral work bear, in her choice of topics, a close relation to the poetics of plot and genre in archaic folklore and literature. The studies she produced during this extraordinary decade of her activity can be placed in three sub-groups:

1) inquiries into mythological folklore plots and genres vs. specific structures of individual plots and genres in European literatures;

2) studies discussing the genesis of individual genres and their specific features (this topic continued throughout the 1940s as well); and finally,

3) works in which Freidenberg sought to define the principle that would enable one to distinguish between religious rituals and the poetics of oral lore-the category of qualitative difference, a new specificum, as it finds its manifestation through different stages of collective worldviews.

Taking into serious account the philosophical aspect of the term "quality as a specificum" in Freidenberg's writings, one should seek farreaching divergencies as well as correlations between her paleontology of culture and socio-historical views on the one hand, and, on the other, between her theories and those of the Formalists. In retrospect, the correlations are apparent; Freidenberg's biography, however, provides limited information on her professional contacts with adherents of either Sociologism or Formalism. Social and ideological superstructures play a very significant role in Freidenberg's theoretical explorations, but the 
philosophy of history is understood differently by her than it is by the Marxist dialecticians. ${ }^{1}$

The Freidenberg-Formalists correlation can be seen as a similarity of macrostructures and dissimilarity of microstructures. At the level of macrostructures, the entire Formalist paradigm can easily be detected in Freidenberg's writings: she treats cultural development as the reconstitution and resemantization of the components of plots and genres; and her transposition of the old substratum onto new semantic forms provides a justifiable analogue to the formalist "resurrection of the word and automatization of the device." Moreover, her treatment of morphology as a discipline studying organic forms (of thought)-their coming to life (taking shape) and recurrent (cyclical) transformations-is clearly present in the fundamental postulates of the Russian Formalists. ${ }^{2}$ One can wholly agree with Nina Braginskaia's observation that in the 1920 s the commonality of the subjects discussed by the Paleontologists and the Formalists resulted in a similarity of their apparatuses. Yet, Braginskaia continues, while starting with the same problems, formulated in the same terms and described with the same technical terminology, the movements took separate courses, and, as they sought different goals, arrived at different conclusions concerning the substance of the same matter. For instance, the "form and meaning" opposition was discussed by both groups in similar terms, and, more importantly, it was viewed from the same perspective. If not for academic footnotes, a contemporary scholar would feel at a loss trying to attribute the following postulate to either the Formalist or Paleontological context: "Any one factor, from which a multiplicity of facts arises, leads to the weakening of the generality and to the accretion of differences. Upon turning into a new phenomenon, when the fact itself becomes a factor, these individual

\footnotetext{
${ }^{1}$ An overview of the problem will be discussed in chap. 10 as "Ol'ga Freidenberg and Grigorii Gukovskii on Historical Poetics."

${ }^{2}$ Nina Braginskaia, in "O rabote O. M. Freidenberg "Sistema literaturnogo siuzheta'" (Vtorye Tynianovskie chteniia [Riga: Zinatne, 1986], 276), and Viach. Vs. Ivanov in "Vvodnye zamechaniia k stat'e O. M. Freidenberg 'Sistema literaturnogo siuzheta"' (Montazh, literatura, iskusstvo, teatr, kino, ed. B. V. Raushenbakh [Moscow: Nauka, 1988], 214-15), demonstrate that in the mid1920 s the Formalists and Freidenberg shared an interest in theories of saltations, mutations, and catastrophes. Likewise, they applied a knowledge of biological genetic theories to the study of verbal arts. Subsequently, the famous Russian geneticist Aleksandr Aleksandrovich Liubishchev (1890-1972), applied the general schema of semantic paleontology and formalist morphology to his treatment of form, taxonomy, systematics, and evolution of living organisms.
} 
differences [of fact-N. P.] will serve as material that will be passed on in the form of the general." ${ }^{3}$

The necessity of distinguishing between the Paleontologists and the Formalists and the difficulties one experiences trying to find a watershed between the two trends grows stronger if we remember that the participants in the Prague Linguistic Circle (1926) spoke of their approach as "Structuralism." The broad contextual similarity of the two different positions is so instructive, that, in order to make it clear to the reader, Ann Shukman, while fully aware of the rift between the Paleontologists' and the Formalists' views, decided to include Freidenberg's "Three Plots, or the Semantics of One" ("Tri siuzheta, ili semantika odnogo") into her anthology of Formalist texts. ${ }^{5}$

As microstructures, the Formalist and the Paleontologist edifices are built upon different foundations, and the theories diverge from each other on the questions of architectonics and composition. The same terminological nomenclature-form, content, material, narrative, rhythm, genre, structure, image, metaphor, and the self-sufficiency of the artistic work-are understood from different philosophical perspectives.

The philosophical underpinning of the controversy with her well-respected opponents was clear to Freidenberg. In 1925-26 she discussed the different roles allotted to the same archaic plot cluster in Cervantes, Calderón, Shakespeare ("Three Plots or the Semantics of One") and in Lermontov and Calderón ("The Methodology of One Motif"). ${ }^{6}$ The main postulates of both studies challenged the Formalists:

3 Freidenberg, "Sistema literaturnogo siuzheta" (1925), quoted from Braginskaia, "O rabote O. M. Freidenberg...," 275. See also Braginskaia, "Problemy fol'kloristiki i mifologii v trudakh O. M. Freidenberg," where the same statement from "Sistema literaturnogo siuzheta" is referred to in order to pinpoint Freidenberg's interest in "the topics of dissimilarities" and her attempts to formulate "the regularity that governs differences and specifics as a necessary function of the law of generalities." Vestnik drevnei istorii 3 (1975): 183.

4 Peter Steiner, Russian Formalism: A Metapoetics (Ithaca and London: Cornell University Press, 1984), 28.

${ }^{5}$ O. Freidenberg, "Three Plots or the Semantics of One: Shakespeare's The Taming of the Shrew," in Formalism: History, Comparison, Genre. Russian Poetics in Translation 5 (1978): 30-52. Without any explanatory footnotes, Freidenberg published this paper as an appendix to The Poetics of Plot and Genre, 335-60. Her unwillingness to polemicize with the Formalists as well as her intention to challenge their interpretations of literary plots are implied and emphasized by this tacit gesture.

6 "Metodologiia odnogo motiva," Trudy po znakovym sistemam 20 (1987), 12030. 
There is no such thing as the image as hypostasis. There is only the concretely reified image, image in the form of metaphor.... It is necessary to start with the premise that an image is engendered by reality, but is perceived against that reality, the premise that sensing and perceiving are non-identical and that the meaning content of this perception, its semantics, is wholly dependent on the given social ideology... Behind each image lies a reality, and in each case we have to do only with what precisely is conveyed from the real world in the given image, by what real phenomenon the given image is localized. ${ }^{7}$

"The Methodology of One Motif" added to the public anti-Formalist proclamation: "Even in the greatest masterpieces, the composition of the plot is not conceived just by free inspiration. The composition is rather one of the instruments (not necessarily consciously chosen) of the forms which are brought about by the nature of the plot." ${ }^{8}$ Freidenberg steadily adhered to her anti-Formalist statement and insisted that although an author chooses the subject for his creations in agreement with his aesthetic taste (freely, as it were), he nevertheless selects only from among the forms which have already been instilled into human culture.

Freidenberg finished "The Methodology of One Motif" in 1925 and wanted to present the paper to the discussion session in ILIaZV, at the time an interregional institution where the Formalists were working together with traditional classicists, comparativists, and paleontologists of culture.

Neither Zhebelev nor I realized that during this time a fierce combat took place between the Formalists, who held the leading position, and the Marxists, who were just coming to power. Eikhenbaum was the head of the one group, and Desnitskii the leader of the other. At that time, I did not understand anything of it.... My presentation could not take place: the Formalists sabotaged the meeting and did not come. Having no interest in their conflict, I was ready to deliver my paper anyhow ... but Derzhavin didn't dare to call the meeting, for he feared political complications. ${ }^{9}$

\footnotetext{
7 "Three Plots, or the Semantics of One," 48.

8 "Metodologiia odnogo motiva," 121.

${ }^{9}$ Vasilii Alekseevich Desnitskii (Stroev, 1878-1958)-Marxist literary critic and historian of literature. Nikolai Savostianovich Derzhavin (1877-1953)-from 1925 head of the Department of Slavonic Studies at Leningrad University. An administrator from the "Red professoriate" (krasnaia professura) and an adherent of Marrism, Derzhavin was an arch-enemy of the Formalists.
} 
The pitched battle happened later, most likely in 1926. Both sides prepared for the combat; a huge crowd came. When I entered the hall, Nik[olai] Vas[il'evich] Iakovlev, the Academy secretary, a crude bureaucrat, approached and warned me, in a sweet voice, that "extraordinary events are expected" and that I had better go home. I remember, I asked: "And who are you?" He departed in disdain, and I did not leave the meeting. What I witnessed aroused anger in me.... One thing was clear: those whom I was ready to support, behaved in a rude, impudent, fraudulent manner. These, with whom I had nothing in common (the Formalists) spoke elegantly, persuasively, and academically correctly. The single combat was between Eikhenbaum, whose speech was smart and excellent, and Desnitskii, who made one blush for him. The huge audience was keyed-up. And there, in the middle of the battle, Desnitskii offered to take a vote: "Who is for the Formalists, who is against?" The whole scene was such an outrageous blackmail and rude misrepresentation, that, all excited, I voted for the Formalists. But then something unexpected happened. "The majority is against the Formalists," Desnitskii lied without polling the votes. "The meeting is dismissed. Everyone who is not elected, please, leave the room." (3: 178-9)

This "free discussion" was a lesson for the rest of her days! For more than twenty-five years Freidenberg continued working together with the prominent theorists of what used to be Russian Formalism (first at the Institute of Speech Culture, and then at the University), but never voiced her vigorous disagreements with their creed. She omitted polemics from her works, because under Stalinism academic disagreements were treated as political conflicts and used as pretexts for the denunciation of "the enemies of the Soviet people." Her decision to spurn open debate was adamant, and when reservations about formalist methodologies reached their culmination, Freidenberg embarked on a travestied exchange. In her talk "On Static Plots and Wandering Theoreticians" Freidenberg expressed her anti-formalist stance under the guise of a theoretical musing, jotted down as "excerpts from a diary." 10 In this paper Freidenberg proceeded from her "Methodology of One Motif" and then, "playing the idiot, treated from the positions of all the different theories that were in circulation at that time (and are still in force nowadays) all the causes that brought about the similarity of plots. I represented the simultaneity of similarities as a simultaneous performance at several stages of a Constructivist theater, and the dissimilari-

${ }^{10}$ Odissei, 272-97. 
ties as a film" (7: 1). Among Freidenberg's disguised opponents one recognizes Boris Eikhenbaum, Boris Kazanskii, Mikhail Petrovskii, and Viktor Shklovskii.

\section{B. Factors, Facts, and Their Interaction within the Literary System, According to Freidenberg and Tynianov}

To reconstruct the actual exchange between Freidenberg and the Formalists, one must speculate on the nature of their theoretical persuasions, moving from group to group and from one cluster of ideas to another. Comparing Freidenberg's views with the theoretical persuasions of the Formalists, who supported the idea of "the literary system," one can see that she, like her opponents, foregrounded factors which are related to a system, yet function within it in such a way that they exert a transforming impact upon its totality. According to Freidenberg, within the limits of their own system factors cause a multiplicity of facts. She traced the interaction of factors and facts through the interrelations of plot and genre, image-concept reconstitutions, and relations between semantics and morphogenesis. All of these binary oppositions were taken into consideration by the Formalists. It suffices to mention Roman Jakobson and Iurii Tynianov, of whom the latter was the main proponent of the "systemo-functional" treatment of literary processes. ${ }^{1}$

In his excellent book on the metapoetics of Russian Formalism, Peter Steiner mentioned (although in passing) Tynianov's indebtedness to Cassirer. Steiner demonstrated that Cassirer's Substanzbegriff und Funktionsbegriff and his treatment of "relation-concept" (according to which "similarity is not considered a property of objects but a categorical tool that enables us to unite disparate objects in a single concept") were taken into account by Tynianov's theory of literary evolution. ${ }^{12}$ Like Freidenberg, yet operating within the framework of another epistemology, Tynianov treated literature as a dynamic hierarchy of dialectical interrelations between literary facts and extraliterary phenomena. Thus, where he had "series and functions," Freidenberg recognized the correlation of "factors and facts." However, unlike Freidenberg, Tynianov defined literary genesis as the specific moment in cultural development in which an extraliterary fact or a non-literary occurrence is recognized as a specifically literary event. He stated that this specific instance in cultural development "has its own significance" whose characteristic features are different from the genetic series, "from the study

\footnotetext{
11 Steiner, Russian Formalism, 99.

12 Ibid., 101. Tynianov's programmatic article "O literaturnoi evoliutsii" ("On Literary Evolution") was published in Na literaturnom postu 10 (1927): 42-48.
} 
of genesis itself." 13 Tynianov treated literary genesis as a study of individual transformations; he associated conditionality with the evolution of the value system which enabled one to relate concrete facts (those located within the system) to extraliterary or literary series-the realms of the broad cultural context open to change. Tynianov "conceived of literature as a dynamic hierarchy, an ongoing struggle for domination among parts and wholes."14

Freidenberg approached ancient folklore, early Greek literature, ancient philosophy, ethics, and religion as a network of coexisting dynamic factors which pointed to the self-reflections of collective consciousness. She associated genesis with the reconstitution between the components of stage and structure, and traced the dynamics of literary processes through the restitution of an old experience via new value compounds whose semantics became specified at more advanced stages of collective consciousness. In "Folklore in Aristophanes" Freidenberg discussed the correlations of static and dynamic reviving impulses within the system, and thus juxtaposed the a-causal period of archaic folklore and the causally conditioned period of literary development. In the case of Aristophanes' plays, for Freidenberg his works ceased to be folklore and brought about literature, along with the genre and the plots of Attic comedy, whereupon "religion lost its actual content and passed into the role of a form." 15

The more subtle the disparity between Freidenberg's and Tynianov's definitions of genesis and evolution, the heavier the weight of epistemology in their systems. Tynianov conceptualizes literary development through cultural history in terms of dialectics and relativity. For him, the dialectics between the perceptibility or the automatization of a speech construction define the development of the literary process. "Whether a fact is literary or not depends on its differential quality (i.e., on its correlation with either literary or extraliterary series)." In other words, the life of a literary fact is a matter of its function in culture and cultural consciousness: "What constitutes a literary fact for one epoch, is but a trite speech construction for another." "literary facts of various periods, disparate in themselves, become related if they are placed within a concrete historical process and viewed according to this process." ${ }^{17}$ Literary facts derive their poetic meaning from the evolutionary process, but every individual author sees his work,

${ }^{13}$ Iu. N. Tynianov, "O literaturnoi evoliutsii," in Poetika. Istoriia literatury. Kino (Moscow: Nauka, 1977), 271, 526.

14 Steiner, Russian Formalism, 104.

${ }^{15}$ Freidenberg, "Fol'klor u Aristofana," Sergeiu Fedorovichu Ol'denburgu, 560.

${ }^{16}$ Tynianov, "O literaturnoi evoliutsii," Poetika. Istoriia literatury. Kino, 273.

${ }^{17}$ Steiner, Russian Formalism, 107. 
his individual achievement, as an artifact that differs decisively from any other item of artistic production. According to formalist systematology, culture is "a complex system of systems composed of various subsystems," within which "extraliterary phenomena relate to literature not in a piecemeal fashion but as an interplay among systems determined by the logic of the system to which they belong." 18 Thus, according to Tynianov, the fundamental Marrist opposition, the stage/structure dichotomy, is a conjectural speculation rather than evidence of organic development in cultural history.

Freidenberg advances the antinomy of noumenal/phenomenal relations as the definitive factor of development. She starts with the premise that in different epochs and at different stages of social development "sensing and perceiving are non-identical and that the meaning content of this perception, its semantics, is wholly dependent on the given social ideology" and its structures. "Behind each image lies a reality," and the difference between religious images of reality, folklore images of reality, and literary or philosophical images of it is defined entirely "by what precisely is conveyed from the real world in the given image," by what real phenomenon the given image is generated. ${ }^{19}$

Freidenberg's semantic model also located genesis and evolution in the process of human development. According to this model, literature facilitates an awareness with specific structures and gives specific expression to various manifestations of the collective perception of reality. Through its own genre categories and images, literature internalizes, resemanticizes, and endows with poetic meaning the planes of human awareness which Tynianov termed "extraliterary series." Rather than challenging her formalist opponents to a continuation of the duel, Freidenberg reaffirmed her thesis, according to which any predominance of one image (or metaphor) over another within the series becomes invalid, for while "we grasp the generic unity (rodovoe edinstvo) of the image only in its precise forms, the image manifests itself in the different forms of its transmission." 20

To better clarify the main reason for the Freidenberg-Tynianov opposition, one must realize that Tynianov's causal determination of the genesis of a literary work focuses on the creative efforts made by an individual author, whereas Freidenberg's "a-causal genesis" points to processes located beyond the territories of the premeditated selection, adaptation, and resemantization of poetic motifs. According to Freidenberg, the simultaneity of the self-manifestations of motifs and their different meaning for different individual authors are not mutually exclusive. The

\footnotetext{
${ }^{18}$ Ibid., 112.

${ }^{19}$ Freidenberg, "Three Plots," 48.

${ }^{20}$ Ibid.
} 
same archaic plot, even when it is cast in similar poetic images, acquires different motivations and interpretations in poetic works produced by different individual European authors. This observation reconfirms her earlier statement that within the limits of their own system factors cause the multiplicity of facts, and in "On Static Plots and Wandering Theoreticians" she brings additional examples of factor-fact interactions, referring to Lermontov's nineteenth-century narrative poem Demon and Calderón's seventeenth-century drama Dedication at the Cross. ${ }^{21}$ In European literatures, identity of archaic plots provides evidence of historically bound differentiations in the poetic awareness of individual authors, rather than restoring a broken sequence of lost and found prototypes, borrowings, and functional and projectional transformations of poetic plot lines.

\section{Freidenberg and the Folklorists of the Formalist School: Vladimir Propp and Petr Bogatyrev}

More light can be shed on the polemical contacts between the Formalists and the Paleontologists of culture if one becomes aware of the general situation in Russian philological studies at the time, and within this context moves from scholar to scholar, from group to group, and from literature to folklore studies. As soon as one consults the pioneers of functional approaches in folklore, Vladimir Propp and Petr Bogatyrev, several common interpretative strategies become apparent, although the sensation of two vying ontologies does not lose its sway.

The folklorists of the Formalist school readily subscribed to the validity of morphologic analysis. In Morphology of the Folktale (1928), Propp's understanding of folktale plots, characters, and their functions conforms perfectly to Freidenberg's system.

Freidenberg met Propp in ILIaZV. As she wrote in her diary, in March 1930, during the discussion of her "Blindman over a Precipice," 22 a person from the audience, whom she did not know, gave wholehearted support to her ideas: "This was the only person from the academic coterie who supported me and approached my views with enthusiasm. Life arranged it in such a way that I could not reciprocate his feelings" (4: 22). Belated lyrical effusions aside, Freidenberg and Propp arrived at the same conclusions yet approached folklore studies from opposite sides. Freidenberg progressed from mythological metaphors and their semantics to morphogenesis, and from there to individual manifestations

\footnotetext{
21 Freidenberg, "O nepodvizhnykh siuzhetakh," 274-80.

22 "Slepets nad obryvom," Iazyk i literatura 8 (1932): 229-44. Written in 1925, the paper was first presented as a talk for the meeting of the mythical sector of the Japhetic Institute in 1928 and then submitted to ILIaZV for publication.
} 
of literary genres. Propp moved from morphology to morphogenesis, and from there to vestiges of archaic life/death antinomies in tribal life, communal experience, and ritual. Both relied on Veselovskii's Historical Poetics, yet raised doubts about syncreticism in the treatment of motifs and cultural survivals. Propp and Freidenberg gave comparable interpretations to the semantics of laughter, dance, and the communal repast in ritual and in other emotive and behavioral acts of the collective. Both found survivals of ritual laughter in folk tale plots, in the narrative, and in the allocation of story-telling to the seasons of the year (the prohibition vs. the eliciting of laughter in archaic rituals; the seasonal prohibition of story-telling in folk rites; the exclusion of the opposite sex from certain ritual performances).

The dissimilarities and affinities of their approaches can be seen from a comparison of Freidenberg's "Blindman over a Precipice" and Propp's "Ritual Laughter in Folklore" and "Oedipus in Light of Folklore." ${ }^{23}$ Freidenberg discusses the apparent "discrepancies," such as the lack of correlations between the plot and motifs in Aristophanes' comedy Plutus: Chremylus, the hero of the play, meets a dirty blind old beggar who does not want to disclose his identity. Carion, the slave servant of the hero, suggests that he lead the old man to the verge of a precipice and leave him there till the latter "pitches over and breaks his neck." At this moment the old man acknowledges that he is Plutus, the God of Wealth, and the entire course of events takes a drastic turn in the play.

In Aristophanes, Freidenberg observes, "the image is not developed into action," the threat is not followed by execution; and the function of Carion's strategem (an imagined precipice) has no connection to the disguised image of the god and his further plot-line. ${ }^{24}$ The elements of Aristophanes' plot, known as scattered motifs from Greek ancient tragedy, reappear in Latin and European prose and drama (Freidenberg lists Lucian's dialogues, medieval fables, carnival performances, Shakespeare, Franco Sacchetti, Alain-René Lesage, Christian apocrypha, and many other texts). The question is, how do literary plots treat the figures of poor old blindmen, and to which kind of motifs do the

${ }^{23}$ Vladimir Propp, "Ritual'nyi smekh v fol'klore (Po povodu skazki o Nesmeiane)," Uchenye zapiski LGU, no. 46. Seriia filologicheskikh nauk (Leningrad, 1939), trans. as "Ritual Laughter in Folklore," in Theory and History of Folklore, ed. Anatoly Liberman, trans. Ariadna Y. Martin and Richard P. Martin (Minneapolis: University of Minnesota Press, 1984), 124-46. "Edip v svete fol'klora" (written 1940, publ. 1944), in his Fol'klor i deistvitel'nost' (Moscow: Nauka, 1976), 258-99. Propp's articles written in the late 1930s were published in 1939 and 1944.

24 Freidenberg, "Slepets nad obryvom," 229. 
plots relate these images? In the figure of a wealthy beggar, Freidenberg reveals the mythological substratum and then suggests:

But perhaps, we can pluck up our courage and read the myth literally, in the language of the images it speaks? Then it will turn out that our wealthy beggar has two biographies. One of the plot, which is present in the theme and in the plot structure $(v$ tematike $i v$ fabule). The other, metaphorical, is constantly present in the surroundings of the place and action. According to the first biography, the old man is a beggar who becomes rich and then loses his wealth. According to the other biography, he is linked to a precipice, to the sea and steepness: that's where he lives, where his dead body belongs, that's where he stays in life and death. But there we see him only in one short instance, episodically, before his falling down. And the semantic identity of the two different motifs makes itself clear when at the very same place, at the moment preceding his falling down, we find another folklore "poor old blindman"-Oedipus. His precipice is the precipitating way of death, a steepness leading to the dark abode of the netherworld. That's the end of Oedipus. From king into disreputable old blindman who dies instantly, vanishing over the steep precipice. ${ }^{25}$

Freidenberg concludes her analysis by juxtaposing the plots and the motifs. An aggregate mass of world literature-from Aristophanes to Shakespeare-did not produce free unbound plot structures. Rather, it resemanticized the traditional clusters of mythological motifs and metaphors: life/death, fertility/barrenness, wealth/poverty, paradise/ netherworld, spiritual wealth/eternal suffering. In Aristophanes, the vestiges of mythological semantics are rendered in the images of a threat; but in Shakespeare, the archaic semantics is not to be found in the contents of the scenes which make up the play. In Shakespeare the old semantics is rendered as a mystification that organizes the form and the composition of the play. In either rendition, however, vestiges of old motifs in literary plots retain their semantic constancy and connections. In Freidenberg's readings of Aristophanes and Shakespeare her interpretative schemata from the "System of the Literary Plot" are quite visible: "a factor causes a multiplicity of facts, leading to the weakening of generality, and to the accretion of differences. When the fact becomes a factor, its individual differences are passed onto the newer phenomena in the form of the general." ${ }^{26}$ Semantic analysis, Freidenberg insists, reveals far-reaching regularities and interconnections between the stages

25 Ibid., 237-38.

${ }^{26}$ Quoted from Braginskaia, “O rabote O. M. Freidenberg... ," 275. 
of social development and the law-governed regularities of communal awareness, between the social worldview and its fixed forms of expression. She illustrates this conclusion by a long inventory of motifs taken from many different sources. ${ }^{27}$

In "Ritual Laughter in Folklore" Propp arrived at analogous conclusions and indicated specifically that he relied on Freidenberg's methodology: "I have taken from the world's inventory of folklore, ritual, religion, and myth everything that relates to laughter. Rituals, beliefs, myths, folk tales, and games also have been considered. I have noted for each fact which people it characterizes. A people, as a representative and example of a particular socioeconomic stage" (Propp's emphasis-N. P. ${ }^{28}$ Like Freidenberg, whose works are mentioned in this paper, Propp distributed his data in two directions: "by varieties of laughter ... and by peoples in accordance with the stage of their development." And as if to reconfirm Freidenberg's conclusions in her analysis of folklore motifs and poetic plots in Aristophanes, Propp stated: "It turned out that there were not two points of view or two possibilities for classification. It turned out that each category or type of laughter characterizes peoples at a certain stage in their economic and social development. The result was a historical sequence, rather than a rootless classification. It proved the connection between types of laughter and the stages and explained certain outwardly puzzling forms of material production in the past." ${ }^{29}$ In "Oedipus in Light of Folklore" the main problem advanced by Propp and the method for its solution were completely within the framework of Freidenberg's approaches:

Propp: The plot does not emerge as a direct reflection of the social structure [ne voznikaet kak priamoe otrazhenie obshchestvennogo uklada]. It emerges from collisions, contradictions, and displacements of different structures. Our task is to trace how the plot is brought about by the displacement.

Freidenberg: [T] he plot is not a plot line, not some "literary form" or a component of an individual author's invention; it represents a law-governed system of social worldviews [predstavliaet soboi zakonomernuiu obshchestvenno-mirovozzrencheskuiu sistemu] which has its own history. ${ }^{30}$

The standard English expressions "social structure" and "social worldview" do not convey the significance of the scrupulously chosen

${ }^{27}$ Freidenberg, "Slepets nad obryvom," 241-43.

${ }^{28}$ Propp, Theory and History of Folklore, 127

${ }^{29}$ Ibid., 128.

${ }^{30}$ Propp, "Edip v svete fol'klora," 262; Freidenberg, "Fol'klor u Aristofana," 557. 
terminology in the original works of the two authors. Propp and Freidenberg used "obshchestvennyi" rather than "sotsial'nyi." In their studies of folklore, they discussed societal rather than social phenomena. Societal phenomena take place in different types of archaic classless collectives and are as yet not incorporated into a stratified hierarchy of values.

The paper on Oedipus, however, marked a threshold in Propp's writings on the theory of folklore. After the mid-1940s, when literary theory was harnessed to an immutable sociopolitical dictum, he pulled back from cultural anthropology and paleontological semantics with their emphasis on epistemology. In 1946 he acknowledged that these general approaches were not able to define folklore's "objectives, its material, or its specific character as an area of knowledge." ${ }^{31}$ Rather than recognize in folklore and folklore studies "a special form of verbal art," the supporters of genetic methods in historical and philological disciplines place it beyond the limits of literature. In order to bring folklore studies back to their true nature, Propp suggested confining semantic and genetic approaches to "the territories" of archaic communal beliefs and the history of aesthetics. ${ }^{32}$

It is quite possible that in the mid-1940s Propp used the same strategy of lines of demarcation which Freidenberg had applied in the 1930s in erecting a protective barrier between her rendition of semantic paleontology and Marr's overtly general interpretations; but now she took this strategic move for a manifestation of opportunism. Hurt by his disloyalty to their common creed, Freidenberg wrote about Propp in her memoirs: "And now we work together, side by side, without even noting each other's presence" (4: 230). Two decades later, in his last study, The Russian Folktale (unfinished, published posthumously), Propp found his way to "please a shadow" of Ol'ga Freidenberg. ${ }^{33}$ Here he traced the history of the folktale genre through world culture and generously acknowledged Freidenberg's contributions to the analysis of folktales from the position of semantic paleontology. ${ }^{34}$

As for Petr Bogatyrev and Ol'ga Freidenberg, their writings on folklore and ethnography reveal an intricate strain of mingled affinities and

31 V. Ia. Propp, "Spetsifika fol'klora," in Trudy iubileinoi nauchnoi sessii LGU. Sektsiia filologicheskikh nauk (Leningrad: Izdatel'stvo Leningradskogo gosudarstvennogo universiteta, 1946), 138.

32 Ibid., 146-49.

33 The expression is borrowed from Joseph Brodsky's tribute to Wystan Hugh Auden. See Joseph Brodsky, Less than One: Selected Essays (New York: Farrar Straus, 1986), 357-83.

${ }^{34}$ V. Ia. Propp, Russkaia skazka (Leningrad: Nauka, 1984), 161-70. 
incompatibilities. ${ }^{35}$ Many of their studies have subject matter in common: folk theater, the functions of theatrical costume, the architectural structure of village theater buildings and peasant houses, and the function of marionettes in the seasonal puppet shows. ${ }^{36}$ Both Bogatyrev and Freidenberg support a multilateral approach to ethnographic data. Both emphasize that there are "very few folk implements and tools whose function is exclusively practical; in village life we find that an object will have aesthetic, regionalistic, and other functions as well." Various items of material culture and manifestations of practices in folk performance "serve many functions other than the strictly practical. The furnishings of the village house, the wall decorations, and other components are objects with practical purposes, as well as signs whose functions are to indicate the religious, regionalistic, social, and other affiliations of the owners." ${ }^{37}$ As has been demonstrated in chapter 4, Freidenberg's "The Architectural Semantics of the Vertep Theater" also provides a long inventory of manufactured things: wooden puppets and marionettes, embroidered clothes, carved furniture pieces. These material objects and implements serve multiple functions and represent generalizing concepts (ideas) and specific (emotive) images. Both scholars insist that in folklore and ethnography "a sign and an object" (Bogatyrev) and "the image and the concept" (Freidenberg) should not be separated. ${ }^{38}$ Presented in this form, the Bogatyrev-Freidenberg affinity is more than a mere similarity of subject matters and academic topics. One might expect a profound methodological similarity. Instead, the more fundamental the affinity, the more irreconcilable are the theoretical disagreements.

In Magic Acts, Rites and Customs of the Trans-Carpathians, Bogatyrev challenged the validity of diachronic historical approaches by his "static" (synchronistic) method. He insisted that the typology of folklore forms be established independently from the typology of literary forms. Adhering to the langue/parole opposition, Bogatyrev differentiated between folklore and literature. Following Saussure, and with the

35 The Freidenberg-Bogatyrev correlation follows my publication in Slavic Review 50: 2 (1991): 381-83.

36 Compare Petr Bogatyrev, The Function of Folk Costume in Moravian Slovakia, trans. R. G. Grum, ed. Thomas A. Sebeok (The Hague: Mouton, 1971); Voprosy teorii narodnogo iskusstva (Moscow: Iskusstvo, 1971); and Freidenberg's discussion of the material form of mythological metaphors in Poetika siuzheta I zhanra, 179-202. See also her "Semantika pervoi veshchi," 16-22; "Architectural Semantics," 41-53; and lectures 4 through 8 in Mif i literatura, 22-49.

37 Bogatyrev, Function of Folk Costume, 102.

${ }^{38}$ Bogatyrev, Function of Folk Costume, 102; 83-84; 95-98; Freidenberg, Mif $i$ literatura, 22-23; "Semantika pervoi veshchi," 19. 
support of his friend and co-author, Jakobson, Bogatyrev never failed to emphasize that "the semiological value of the phenomenon can and should be studied outside all the historical preoccupations." ${ }^{39}$ Bogatyrev believed that historical reconstructions of semantic clusters and primeval antinomic identities disintegrate functional structures and separate signs from objects. ${ }^{40}$ Bogatyrev's reaction against diachronic approaches was, of course, a polemical overstatement. Adding historical, semantic, and paleontologic interpretations to his analytical methods would enable one to discern a common substratum of pagan culture in both old and new folk rites and customs. The authentic forms of popular folk culture would gain a multitude of functions when their constituent features were projected against the background of historical semantics.

Using the "law of magic participation" by Lévy-Bruhl, Bogatyrev described a rite of the Transcarpathian peasants-putting a rope on the legs of the dining table; and supported by the synchronic law of magic participation, he described the network of magic functions attributed to this act (protecting the herds in the pastures from being scattered). Following Lévy-Bruhl, Bogatyrev stated that an action performed on one object exerts its effect upon another, even when they are at a temporal and spatial distance from each other: the magic functions ascribed to the "hobbling" of the table in the peasant's hut were transferred onto the herds in the fields. ${ }^{41}$

In the late 1920s through the mid-1930s, Freidenberg (like other Soviet folklorists, including Propp) was not familiar with Bogatyrev's writings. ${ }^{42}$ Her semantic methods, however, also dealt with the multistage relations between the functions of signs and objects. Freidenberg's diachronic approach would trace correlations between the two objects and one predicate: the legs of the table $\left(O^{\prime}\right)$, the legs of the cattle $\left(O^{\prime \prime}\right)$, and the hobbling of lower extremities (P). In addition to Bogatyrev's static synchronic interpretation of the magic functions of different isolated objects, Freidenberg's paleontology would restore the archaic formula of the spell that presumably accompanied the magic performance, yet has been erased from the collective memory of the peasants.

\footnotetext{
39 Roman Jakobson, Language in Literature (Cambridge: Harvard University Press, 1987), 445. See also "Fol'klor kak osobaia forma tvorchestva," written by P. Bogatyrev in coauthorship with Jakobson in 1929, in P. Bogatyrev, Voprosy teorii narodnogo iskusstva, 362-83.

40 Bogatyrev, Voprosy teorii, 180-85.

41 Ibid., 189, 195.

42 Works produced by expatriots (whether émigrés or Soviet citizens working abroad, like Bogatyrev) were not available even to the erudite Soviet folklorists, while the writings of so-called bourgeois scholars were selectively filtered by censorship in the late 1920s-mid-1930s.
} 
Following her object-predicate equation, the magic spell would read: As the legs of the table are strapped in the hut, let the legs of the cattle be hobbled in the pasture.

Bogatyrev also described the trans-Carpathian polazniks, domestic animals or people who enter the peasant's hut on Christmas Eve. Harbingers of the household's good or bad luck, the polazniks form two opposite groups. ${ }^{43}$ Freidenberg, the follower of semantic paleontology, would argue in this case that the trans-Carpathian peasants distinguish between bad and good omens proceeding from a bottom/top opposition. This cultural survival constitutes the semantic cluster 'life/death', where life-giving force is rendered through images of a producing, procreating womb, bowels, entrails of earth or of a being, and where death is envisioned as futility, sterility, virginity, starvation. Thus, as polazniks, a virgin or an old woman portend bad luck and lean years. Either represents those whose wombs do not yet or no longer conceive. Conversely, a young peasant lad, a bachelor, or a man who comes from the riverside or from a downhill area are all emblematic of the ability to procreate and are good polazniks. Mysteriously, a Jew is considered to be a good polaznik (an omen whose meaning the peasants were not able to explain to Bogatyrev). ${ }^{44}$ Freidenberg's understanding of antinomic identities would readily suggest that a Jew, that is, the successor of those who had sent Christ to Calvary, symbolizes resurrection, the life-giving death antinomic unity, and is a sign of good luck and wealth. ${ }^{45}$ Polazniks are arranged by groups according to rigid semantic regularities, yet the regulative principles (or factors) that structure the distribution of the facts have been obliterated from the peasants' memory.

The Bogatyrev-Freidenberg parallel demonstrates that diachronic and synchronic studies should be closely interconnected. Forty years after his first publication of Actes magiques, rites et croyances en Russie Subcarpatique Bogatyrev prepared this work for publication in Russian in the Soviet Union. In the preface he acknowledged that "the diachronic approach helps to trace historical facts analogous to those that are studied by means of the synchronic method. In ethnography and folklore studies, one can reach interesting results by applying combined synchronic and diachronic methods." ${ }^{46}$ The suggested fusion of the two

\footnotetext{
43 Bogatyrev, Voprosy teorii, 218-23.

44 Ibid., 221.

${ }^{45}$ A semantic equivalent of this residuary peasant belief can be seen in John 4:22: "We worship that which we know, for salvation is from the Jews." In her papers "The Cross at the Grave" (unpubl.) and "The Methodology of One Motif," Freidenberg discusses the category of archaic antinomic identities which portend the transformation of demonism into saintliness.

${ }^{46}$ Bogatyrev, Voprosy teorii, 170.
} 
approaches has not yet been achieved. Several steps in this direction taken in Russian and Western scholarship will be discussed in chapter 12 of this monograph. 


\section{Habeant sua fata libeli}

Преемственность - вещь почтенная, конечно... Но бывают также этапы в истории науки, когда, при всем уважении к достоинствам предшественника, хочется от него отгородиться; и, как ни почтенна традиция, - бывают такие исторические этапы! - появляется желание показать вещь по-иному, пусть не с должной законченностью и удачей, но в противовес именно этой чрезмерно доброкачественной и чересчур самонадеянной преемственности.

Ольга Фрейденберг, Поэтика сюжета $u$ жанра, «Предисловие», 11 августа 1935 г.. 
Chapter 7

\section{Suppression and Release of The Poetics of Plot and Genre}

\section{A. Reopening the Department of Classical Studies in the Soviet University}

W Then Marr entrusted the guidance of the group for the paleontological study of myth and folklore to Freidenberg, she was working as a part-time researcher for the Japhetic Institute (IIaM), and as a full-time scholar at ILIaZV (in 1931 renamed the Institute of Speech Culture, Institut rechevoi kul'tury, IRK). IRK combined scientific research with the training of graduate students (aspirantura), and following the 1931 decree on the reorganization of higher education, Freidenberg was made responsible for organizing the institute's graduate-school program. ${ }^{1}$ As she recalled, the decree was met with enthusiasm, "demagogical destruction was abandoned in favor of scientific and academic construction" (nauchno-uchebnoe stroitel'stvo, 5: 24). In 1932, the School of Philology at LGU was given the status of an independent institution: the Leningrad Institute of Philosophy, Linguistics, Literature, and History (LIFLI), and it was decided to reopen the Department of Classical Languages under its auspices. Among seventy candidates for the position of Department head, only Freidenberg met the requirements of the Search Committee. Since the Search Committee was seeking a scholar combining traditional academic training (Zhebelev's school) and knowledge of Marr's theories, she was entrusted with "the reigns of government" by a new bureaucracy. At first Freidenberg countered this offer by suggesting several senior scholars as deserving candidates, yet soon realized that it was beyond her powers to make the committee ignore "ideological principles" in

\footnotetext{
${ }^{1}$ For the text of the decree, see: Direktivy VKP(b) $i$ postanovleniia sovetskogo pravitel'stva o narodnom obrazovanii, 1917-1947 (Moscow: Ministerstvo prosveshcheniia SSSR, 1947), 151. For an analysis of the reform, see Gail Warshofsky Lapidus, "Educational Strategies and Cultural Revolution: The Politics of Soviet Development," Cultural Revolution in Russia, 1928-1931, ed. Sheila Fitzpatrick (Bloomington, IN: Indiana University Press, 1984), 99-104.
} 
appointing a new chairperson. However, the old university "guild" believed, erroneously, that she was seeking power, and they acknowledged her status very unwillingly. Zhebelev felt offended that she did not cede the position to him: after all, he was an acknowledged member of the Russian Academy of Sciences, while Freidenberg held only a master's degree which she earned under his tutelage. How could Zhebelev know that it had been precisely his membership in the Academy of Sciences which led the committee to resolutely vote him down $!^{2}$

While the reorganization of educational institutions in 1932 seemingly promised a return to "the status quo ante" in higher education, the 1929-32 political campaign deprived the Academy of its former relevance, stripped the institution of the privileges guaranteed by the old statute, and took as its victims four members of the Academy from the division of the Human Sciences, all of whom were given political trials. The Machiavellian "divide et imperia" strategy chosen by the party cut both ways. By squelching the resistance of the most independent individuals, the party secured its domination over the Academy. ${ }^{3}$ This insidious strategy sowed discord between the Academy of Sciences and its branches (institutes for scientific research) on the one hand, and institutions for higher education, on the other. While the first group was accused of not being able to "pass the vote of confidence of the Communist party and of the working masses" and underwent purges, the second was instructed to raise academic standards to match those achieved by the intelligentsia before the Revolution. In October 1932 the People's Commissariat for Higher Education reintroduced the old academic degrees and dissertation procedures and assigned the Highest Qualification Board (vysshaia kvalifikatsionnaia komissiia) the duty of certifying the validity of academic studies for the conferment of degrees. ${ }^{4}$ With the establishment of the Qualification Board, university scholars became subject to a dual control of the party bureaucracy and of the academic elite.

Freidenberg never cherished any illusions about the radiant future of the humanities in the Stalinist state, and soon came to realize that the advancement of new objectives in higher education did not change the

\footnotetext{
${ }^{2}$ In "The Case of Four Academics" (1929-32), the defendants were Zhebelev's old friends and colleagues: V. N. Beneshevich, S. F. Platonov, N. P. Likhachev, and E. V. Tarle. For his contacts with émigré scholars Zhebelev was blacklisted in November 1928. See F. F. Perchenok, "Akademiia nauk na 'velikom perelome," Zven'ia 1 (1991): 183-87.

${ }^{3}$ For references to and quotations from M. Kalinin's and A. Enukidze's statements, see Aleksei Rostov, "Delo chetyrekh akademikov," Pamiat' 4 (1981): 471.

4 "Zakon ob uchenykh stepeniakh i zvaniiakh, utverzhdaemykh Vysshei kvalifikatsionnoi komissiei (VAKK)," Biulleten' LGU 10 (1932): 1-16.
} 
political attitude of the party toward the intelligentsia. An emphasis on the individual achievements of both students and teachers and a restoration of required academic courses, examinations, and academic degrees had been accompanied by strict ideological control over scholarly writings, where punitive censorship grew ever stronger. The change in admission policies allowed a larger proportion of well-read, educated students with an "advantaged family background" into the university. The social contrast between them and those students who were uninformed in the arts and sciences was exploited in order to foment squabbles and denunciations, which, in turn, served to undo the remaining corporate traditions. Freidenberg hated the substitution of "meritocracy" for proletarian democracy, and depicted this fake Renaissance as the "Feast during the Plague," a whirl of drummed-up festivities cut short by Kirov's assassination.

Although Freidenberg treated the promulgation of the decree on the reorganization of higher education as a temporary breakthrough, she believed that conscientious intellectuals, like herself and her friends, should accept administrative positions to protect the academic system from ignorant bureaucrats. Sober and vigilant as she was, Freidenberg nevertheless remained unaware of the tragic events which took place very near to her. It did not occur to her that a favorable quota of students from educated and well-to-do families and a revision of pedagogical approaches would follow on the heels of the cardinal restructuring of the Russian Academy of Sciences. ${ }^{5}$ Only after the Academy had been morally demolished and destroyed as a bastion of independent thought was the decision made to recommence under the supervision of Party authorities and to bring up a generation of skilled, servile professionals. The main goal of this cultural politics had been later defined as "the construction of the Stalinist psyche." ${ }^{6}$ Its destructive impact became clear to Freidenberg only later, and in her memoirs, she gave honest expression to her belated disillusionment with this reality.

Freidenberg accepted the new position rather reluctantly:

I had no calling for pedagogical work. Already a senior research scholar at IRK, I had never been a university educator. I had reconciled myself long ago to my expulsion from our institutions of

\footnotetext{
${ }^{5}$ Loren Graham provided a survey of the problem in The Soviet Academy of Sciences and the Communist Party, 1927-1932 (Princeton: Princeton University Press, 1967). His data and interpretations have recently been complemented by numerous émigré and "mainland" Russian publications, of which the most important is Perchonok's analytical study "Akademia Nauk na 'Velikom perelome." See note 2.

6 The title of Joravsky's article, published in Fitzpatrick, ed., Cultural Revolution in Russia, 105-18.
} 
higher education: no matter how I tried to break down their walls, they did not accept me even to teach the Greek language. And all of a sudden - the entire department! Taking power had always been burdensome to me.... The idea of professionalization, of being limited only to the sphere of classical philology, was alien to me. To rally my own enemies, to provide them with a platform, to do for them what they had refused to do for me-and to function among those "ichthyosauri"-all inherently hostile to me, all miserable and backward! To trade them for bright-minded friends like Khona [Frank-Kamenetskii-N. P.] $\ldots$ and my other colleagues from IRK. (5: 57-58)

But finally, after two months of vacillation, she came to the conclusion that her acceptance of the position would be beneficial-for her colleagues, for the students, and for the development of classical studies.

In 1932 Freidenberg became head of a Department which actually did not yet exist and was to be built anew. Her appointment was approved by the university administration late in November, in the middle of the academic year, and did not release Freidenberg from her duties at IRK, where she continued to serve as the Graduate School supervisor (zaveduiushchii aspiranturoi) until the end of 1933. Her administrative responsibilities in the Department of Classical Languages made great demands on her time, and she needed all of her courage and goodwill to support and advocate for those who were hunted down and persecuted by the GPU. Due to the late opening, she side-stepped the quota which required the acceptance of a set proportion of young people from working families and of those with an "advantaged family background." In their stead she accepted a considerable number of students who were children of the nobility, of high-placed intellectuals, and of priests (5: 24-25, 112).

Freidenberg offered academic positions to erudite, yet old-fashioned, scholars from the pre-revolutionary era: S. Zhebelev, A. Malein, I. Tolstoi, M. Pokrovskii. She hired a group of talented colleagues from IRK and IIaM-Solomon Lur'e, Tronskii, and $\mathrm{Al}^{\prime}$ tman, as well as her former peers from Zhebelev's seminar of the 1920s-Andrei Egunov and Aristid Dovatur, brilliant translators of ancient Greek prose. Also given positions in her department were Adrian Piotrovskii, the theater historian and a translator of Aristophanes, and Sofiia Melikova-Tolstaia, a classicist who started her education in Heidelberg.

Freidenberg encouraged her colleagues to publish textbooks, anthologies, and manuals, and they produced an annotated anthology 
Ancient Theories of Language and Style. ${ }^{7}$ She rearranged the course distribution: "first year-general propaedeutic as an introduction to the subject courses; for every new semester-a new period of history with the topics that belong to it (the archaics, the classics, Hellenism, the Republic, the Empire)" (5: 58). She also wanted to introduce a new systemic approach to the humanities, so that Ancient Greece was to be studied together with the Ancient Orient, and Rome with the Middle Ages. Unfortunately, this synchronistic treatment of cultures did not find approval in Moscow. From 1932-36 Freidenberg remained affiliated with both IRK and IIaM and contributed to their publications-she submitted "Folklore in Aristophanes" to Sergei Ol'denburg's Festschrift, and two other papers to Marr's memorial collections. ${ }^{8}$

Aware of her elder colleagues' hidden disapproval of her academic credentials, Freidenberg decided to develop the research she had been conducting over the previous seven years into a thorough topical study and to submit it to the University Academic Council in fulfillment of the requirements for the doctoral degree. At first she felt uncertain whether this step was feasible. Exhausted and overburdened with her routine job, she also feared that this study would suffer the fate of her master's thesis-that it would not be published and would remain unknown to the community of scholars. In February 1934 she described her psychological state to Leonid Pasternak: "I feel weary and exhausted by digging in the past. All of it has already been lived through and passed through. The eternal return to my scholarly bygone days has killed my thought and covered my heart with dust and ashes."

By the beginning of the new semester, however, she found herself all absorbed in her project:

It has been two months already since I harnessed myself to a heartbreaking endeavor-the reworking of my capital study The Poetics of Plot and Genre, which was written seven years ago and which is now going to be presented as a doctoral dissertation. Ostensibly, no one (myself included) has any need for this wearisome labor. But academic degrees have been reinstituted here, and although they will be conferred on the basis of less than what I have already done, but-but you know my "buts." The old academic coterie, despite our good relations, will exact payment from me for all the sins of our ancestral mother Eve,

${ }^{7}$ Antichnye teorii iazyka $i$ stilia, ed. O. Freidenberg (Moscow-Leningrad: 1936). For a photocopied edition, see Antichnaia biblioteka (St. Petersburg: Aleteia, 1996).

8 "Fol'klor u Aristofana," 549-60. "Iz do-gomerovskoi semantiki," Akademiia nauk akademiku N. Ia. Marru. XLV (Moscow-Leningrad: AN SSSR, 1935), 38192; "The Plot Semantics of the Odyssey." 
especially for this autumn, when I've eaten plenty of apples. Academician Zhebelev, my "ex-coach" [eks-uchitelka], now working at my department (!!!) is particularly truculent about these dissertations, and he will have the deciding vote. ${ }^{9}$

In less than a year Freidenberg succeeded in completing her project, and on 9 June 1935 presented it for defense. Zhebelev and FrankKamenetskii, the officially appointed discussants of her dissertation, wrote highly positive evaluations of her work, and the next day the University daily and the Red Newspaper (Krasnaia gazeta, Leningrad) published the laudatory articles "Triumph," and "First Woman, Doctor of Literary Studies."10

In all probability, the information submitted to the Leningrad press was read by the head of the Government Publishing House (GIZ), L. V. Tsyrlin, who offered to publish the dissertation for her. "For a long time I did not trust his words. Knowing the worth of Soviet law, I did not trust the signed agreement either. Neither did I trust the first honorarium, nor the acceptance of the manuscript by the editorial office, not even the galley pages"(5: 142). Finally, by the beginning of May 1936 The Poetics of Plot and Genre was published. Yet only three weeks after its publication, the book was banned by Gorlit and confiscated from book stores. ${ }^{11}$

\section{B. Travels through the Labyrinths of Power: The Adventures of The Poetics of Plot and Genre}

The efforts undertaken by Freidenberg to rescue her creation from oblivion bring to mind the travels to the Kingdom of Death undertaken by the heroes of antiquity. The sixty-odd pages that Freidenberg dedicated in her diaries to an account of her trial help one to understand the mecha-

${ }^{9}$ Ol'ga Freidenberg to Leonid Pasternak and his family, 13 February 1934, pp. 5; 27 November 1934, pp. 1-2, The Pasternak Trust, Oxford, unpublished.

${ }^{10}$ In her diaries, Freidenberg copied Zhebelev's evaluation of her dissertation (a skillful twenty-odd-page summary of the work), an article, "Torzhestvo," by Liubov' Semenovna Izrailevich (in 1935-36 a graduate student at LGU, arrested in 1937), and an article "Pervaia zhenshchina-doktor literaturovedeniia," Krasnaia gazeta, 10 June 1935, written by an old newsman, M. S. Shpitser, a former coworker of Ol'ga Mikhailovna's father. 5: 125-32, 140-41, 141-42.

${ }^{11}$ In her diaries Freidenberg writes that "three weeks" after The Poetics of Plot and Genre was published, she heard from I. Tronskii about its confiscation (5: 185). Her recollections are not quite accurate: "three months" later, on 28 September 1936, Izvestiia published a denunciation of her work, a critical review "Pernicious Balderdash" (vrednaia galimatia) by Tsilia Leiteizen, but the book was not yet confiscated. 
nism of Stalinist myth-making and, in particular, the public performances during which invisible party authorities acted under the guise of the broad masses and submitted political dicta as a spontaneous expression of the voice of the simple people. ${ }^{12}$ In the last week of May 1936 an anonymous local denouncer scolded Friedenberg harshly and charged her with "disrespect to Homer." Freidenberg's first reaction was to rebuff the denunciation immediately. On 2 June 1936, she addressed Karl Bauman, the supervisor of the Department of Sciences, Discoveries, and Inventions at the Central Committee:

I am writing to a representative of the Central Committee; I have no need to draw the conclusions. You understand things better than I. Even when a person is led to capital punishment, the indictment is read out to the offender. But I know nothing about the cause for the public and moral ruination of my work. I do not intend to extort an explanation of the hidden circumstances behind the scenes at GIZ and Gorlit, neither am I going to solicit petitions to bring my work back to life. What is important for me is that the system lacks any deference to academic work, whether the system takes the shape of reviews by calumnious pen-pushers, or of direct repressions. (6: 4-5; emphasis Freidenberg's)

Я пишу представителю ЦК партии - и выводов мне делать не нужно. Вы понимаете вещи лучше, чем я. Когда человека ведут на смертную казнь, ему и тогда читают обвинение. Но я ничего не знаю о причинах общественной и моральной гибели моего труда. Я не намерена вымогать их на задворках Госиздатов и Горлитов, ни хлопотать о воскрешении из мертвых. Для меня важна система неуважения $\kappa$ научному трудy, выливается ли она в рецензии борзописцев или в прямые репрессии.

The petition remained unanswered, but further developments made Freidenberg understand that the ban was in some way connected with the division of power between the Academy of Sciences and the Communist Academy. ${ }^{13}$ Less than a month after her book was published, Valer'ian Aptekar', a militant adherent to the Marxist treatment of the New Teaching on Language, a leading figure in the Linguistic Front faction, and a professional supplier of "politically correct" book reviews

12 Mossman, Correspondence, 157-71; Freidenberg, Race of Life, 6: 1-69. See also my "Primeval and Modern Mythologies," 193.

13 The Communist Academy was established in Moscow in 1918 under the guidance of M. N. Pokrovskii. In 1930 a branch was also established in Leningrad. 
and brochures ("The Present Situation in the Linguistic Front and the Urgent Tasks of Marxist Linguists"), forwarded his critical notes to Freidenberg. ${ }^{14}$ Aptekar' stated blatantly that Freidenberg followed an outdated rendition of Japhetic theory; had a poor knowledge of Marxist literature; underestimated the significance of Hegel's dialectics; and treated several bourgeois concepts in a simplistic and deviant manner. He also faulted Freidenberg for her excessively laudatory evaluation of Frank-Kamenetskii's scholarship-she refused to criticize his views, whereas they deserved severe criticism. Aptekar' reproached her further for her reluctance to entertain critical discussion of the works which supported the fundamentals of the outdated Japhetidology and played down the achievements of the New Teaching on Language. To sum up, Aptekar' continued, Poetics gave evidence of Freidenberg's ideological short-sightedness: "Nowadays, with all the open and clandestine harassment of N. Ia. Marr, to be more precise- of his great deed, when it is necessary to pour cauldrons of tar on the heads of these loathsome skunks, every wrong step is particularly dangerous; every less-thanpenetrating analysis serves the purpose of the enemy." 15 The letter read as a warning that Freidenberg, along with Frank-Kamenetskii, belonged to a wayward faction of Marrism whose activities were to be unmasked. Typically for the mid-1930s, the harassment was signaled by a "friend" who vigilantly scrutinized the academic achievements of his confederates in the ranks of Soviet scholars.

As it turned out, the Communist Academy had not officially appointed Aptekar' as Freidenberg's public prosecutor. Both he and Bau-

${ }^{14}$ V. B. Aptekar', S. N. Bykovskii, "Sovremennoe polozhenie na lingvisticheskom fronte i ocherednye zadachi marksistov-iazykovedov," Izvestiia Gosudarstvennoi akademii istorii material'noi kul'tury 10: 8-9 (1931). Freidenberg met Aptekar' in 1929 during her business trip to the Communist Academy in Moscow. Uneducated yet self-confident, Aptekar' was one of the leaders who managed to "master Party slogans, newspaper jargon, the bare bones of Marxism, and assume the role of bosses and dictators" (Mossman, Correspondence, 125). Typical of Aptekar"s treatment of Marr is the following statement: "Long ago, prior to N. Ia. Marr's studies, the essence of the primeval consciousness had been penetratingly grasped by V. I. Lenin in his 'Notes to Aristotle's Metaphysics"' (N. Ia Marr i novoe uchenie, 126). On Aptekar's role in the Linguistic Front and on his doctrinaire treatment of Marr's linguistics, see Alpatov, 84-86, 95-97.

15 For Aptekar's letter, see Race of Life, 6: 7-8. Its conclusion provided the preliminary formulation for a charge which could be brought against Freidenberg: "I know you, Ol'ga Mikhailovna, as an advanced person, and therefore address you without any fear of hurting you individually. I urge you to shake off the oldtestament Japhetic Adam [sic!-N. P.] and to start acting resolutely, abandoning Izrail' Grigorievich's sugary water (with the Kantian whiff)" (ostaviv pozadi sladenkuiu vodichku [s kantianskim dushkom] Izrailia Grigorievicha). 
man were arrested in 1937, but in 1936 their authority and power remained unquestioned, and Freidenberg's colleagues believed that her selfless attempts to save the book from perdition were hopeless. In July 1936, an anonymous denouncer T. N. (Tat'iana Nikolaeva) published in Red Virgin Soil a lampoon "This Blind Man Homer." The pastiche was not Nikolaeva's only attempt to cast a slur upon the Classics Department of Leningrad University; earlier in May she had submitted to the journal her ignorant review of Ancient Theories of Language and Style, edited by Freidenberg. ${ }^{16}$ The rapidity of T. N.'s onslaughts on the university classicists raised suspicions that her pen was pushed by the invisible hand of a well-informed internal player, and indeed, later Freidenberg found out that the instigator of the assault was I. I. Meshchaninov, her old adversary from IIaM and IRK (6: 67). But by 1936 Red Virgin Soil had begun to lose its leading position in determining the ideological views of society, and during the summer, when ideologically reliable reviewers were not on hand, the persecution did not yet attain its full sweep of violence. The real war was declared on September 28, following the publication of Tsilia Leiteizen's pamphlet "Pernicious Balderdash" in Izvestiia. ${ }^{17}$

Izvestiia was an official Party newspaper. Its every word had an official significance, the practical results of which (or as was then the phrase, "the organizational implications") could not be overestimated. $^{18}$

A calumniator of a much greater harshness than her feeble colleague T. N., Leiteizen, consequently, took her guidance from a political figure of much higher authority than Meshchaninov. She was instructed by P. I. Lebedev-Polianskii, the editor in chief of the Literary Encyclopedia and Literary Heritage, who was also responsible for the Classical section in Glavlit. Leiteizen labeled Freidenberg's book "anti-Marxist balderdash" and charged everyone privy to the publication of the book with lack of ideological vigilance: Zhebelev and Frank-Kamenetskii, the "official discussants," who acknowledged the study and accepted it as a doctoral dissertation; M. S. Epstein, assistant to the Peoples' Commissar of Education and Chairman of the Highest Qualification Board, who sanctioned Freidenberg's doctorate; and L. Tsirlin, the editor of the

${ }^{16}$ T. N., "Etot slepets Gomer," Krasnaia nov' 7 (1936): 270; Freidenberg copied Nikolaeva's article in Race of Life, 6: 12-14. T. N., "Teofrast i drugie," Krasnaia nov' 5 (1936): 238.

${ }^{17}$ Freidenberg copied Leiteizen's article (Izvestiia, no. 226, 1936) in Race of Life, 6: 15-22.

${ }^{18}$ Mossman, Correspondence, 158. 
State Editorial House, who published the harmful manuscript (for which he was dismissed from GIZ). ${ }^{19}$

Armed only with her human and professional dignity, Freidenberg appealed to the Central Committee of the Communist Party, to the Department of Sciences at the Commissariat of Education, and, when these two petitions remained unanswered, addressed Stalin himself. For two months (ostensibly, while Stalin was vacationing in the South) Freidenberg remained, as it were, dangling between life and death, ostracized and alienated from her colleagues. Then she was sent to Moscow for an appointment with Boris Volin, the Deputy Commissar of Education, the successor of Lebedev-Polianskii at the State Publishing House, and from 1934 the supervisor of the Main Management of the Literature and State Publishing Houses (GLAVLIT). On 10 November 1936, in her absence from the University, an extraordinary session of the Department of Ancient History was called to discuss the Poetics, and as the minutes stated, the Department acknowledged that "on the whole, the work of Freidenberg is anti-scientific, antihistorical, and not only is it alien to Marxism, it also contradicts the very foundations of the Marxist-Leninist scientific methodology" (6: 50). In a characteristic feature of the time, five of the seven referees were not at all familiar with the book under discussion, a fact that did not deter them, however, from formulating their opinions in writing. M. Al'tman expressed his bewilderment at Freidenberg's absence, yet nevertheless declared his disagreement with "some of her ideas," and only Raisa Shmidt dared to rate the book as a valuable academic achievement (6: 44-49). Meanwhile in Moscow, simultaneously, "the erstwhile censor" Comrade Volin found nothing objectionable in her book and assured Freidenberg that "there had been a mistake": "It appeared he had 'studied' my book and found nothing in it contrary to Marx's teachings. He only scolded me in a fatherly way-that is precisely what it was, fatherly-for my difficult language and 'scrupulousness'.... In parting he said to me: 'You will not be bothered again.... You have the right to publish your work freely; your good name has not been sullied in any way."20

An inquisitive interrogator, Volin did not fail to inquire whether Freidenberg knew who her "ill-wisher" was, and when Freidenberg named Volin's arch-rival Lebedev-Polianskii, he "grunted with an approval," and assured her that the Poetics would be back in circulation. "The atmosphere in Leningrad," Freidenberg recollected, "was completely changed when I got back, and it was as if the former one had never existed. How, from what source, had the news reached them? By

\footnotetext{
${ }^{19}$ Izvestiia, no. 263, 14 November 1936; Race of Life, 6: 57-58.

${ }^{20}$ Mossman, Correspondence, 165.
} 
what radio? Can radio change the climate?" ${ }^{21}$ However, Izvestiia, receiving no instructions from Volin, relapsed into another assault on Freidenberg's book and on her Department. ${ }^{22}$ This time FrankKamenetskii went to Moscow and encouraged Boris Pasternak to contact Bukharin, the editor of Izvestiia. Pasternak's letter (copied and saved in Freidenberg's cache) was not delivered to its addressee, for by this time Bukharin was under house arrest, and "while his case was being 'investigated,' Izvestiia continued cynically to carry the name of the editor-in-chief who was already condemned to death." ${ }^{23}$ Only after Volin telephoned the vice-president of the University and instructed him to cease criticizing and obstructing Freidenberg's writings, did the persecution come to an end. As Freidenberg sarcastically noted, the review of the Poetics remained Leiteizen's only contribution to Classical studies, for by mid-December 1936, her advisor Lebedev-Polianskii himself became a target of severe criticism. He survived this assault successfully to be promoted even higher in the hierarchy of "apparatchiks."

The story of the suppression and release of The Poetics illustrates the practice of organized persecutions and shows the utter helplessness of the victims in proving their innocence. Any individual support offered to Freidenberg by her colleagues was deemed a mistake. FrankKamenetskii's letter of support submitted on behalf of Freidenberg to the Highest Qualification Board was misquoted and distorted in Leiteizen's pamphlet, and Raisa Shmidt, who acknowledged the validity of Freidenberg's study, won the reputation of a politically suspect person.

On the other hand, in Freidenberg's audacious campaign against injustice one recognizes family features common to all the Pasternaks. As soon as Boris Pasternak read Leiteizen's article, he sent Freidenberg a long and emotional letter. "In this whole business the only thing I worry about is that you are not hardened; it is your first experience of this kind.... I cannot come to you now or in the near future, much as I should

21 Ibid., 166.

22 Izvestiia, no. 263 (14 November 1936.).

${ }^{23}$ Race of Life, 6: 57-62; Mossman, Correspondence, 167-68. In her memoirs, Freidenberg erroneously confused the chronological order of several events. Most likely, Frank-Kamenetskii visited Boris Pasternak urging him to contact Bukharin before she was scheduled for an interview with Volin: the copy of Pasternak's letter to Bukharin bears no date, yet his letter to Freidenberg in which he describes briefly Frank-Kamenetskii's visit to his summer house in Peredelkino is dated 7 October 1936. And on 8 October, Freidenberg thanked Boris's wife Zhenia for "receiving [her] emissary so well" (Mossman, Correspondence, 169-70). 
like to and probably ought to. Couldn't you come here? You would have a separate room and would find yourself in a company made up almost entirely of victims like yourself." ${ }^{24}$ As Freidenberg later described her ordeals to Leonid Pasternak, "the boys" (Boris and Alexander-N. P.) greeted her lovingly in Moscow and celebrated her victory at Volin's with a family dinner. ${ }^{25}$

The campaign made Freidenberg see with her own eyes the hidden gears and levers of the apparatus that corrupted people's perceptions. She did not cherish sentimental dreams about the moral fortitude of her colleagues, but she was injured by the opportunism, sycophancy, and irresponsibility many of them demonstrated during the days of her ordeal. Unlike Odysseus, Orpheus, Psyche and other ancient heroes who traveled to the Kingdom of Death, she had no "magic helpers" at her disposal; rather a violent struggle between the powers of evil at the highest echelon of the Party had miraculously protected her from destruction. Freidenberg would not have been able to win her campaign, were it not for the feud between the top Party officials who urged Volin (a candidate put forward by the Central Committee and a Deputy Commissar of Education) to undermine Lebedev-Polianskii (a representative of $\mathrm{Bu}$ kharin's camp and the political supervisor of academic sciences). In this battle of the chthonic forces Freidenberg was used as an infinitesimally small pawn whose personal views and moral values were of no meaning whatsoever. In The Race of Life she analyzed the patterns of contemporary myth-making and the atavistic reversion of social awareness from causality to totemism. Freidenberg demonstrated how the social consciousness of the "brave new world" had set itself in opposition to human history and its cultural values. In accordance with her semantic paleontology, she discerned intertwined clusters of meanings, whose common lexical denominator was corruption-the corruption of social justice and human rights; of civic dignity and human freedom; of language and interpersonal contacts; of people's individual morality and social awareness.

The intimate pages of The Race of Life read like a meta-philosophical counterpart to The Poetics of Plot and Genre. They can be compared to the semi-autobiographical notes originating from Ernst Cassirer's famous essay "The Myth of the State" (1944) and his extended posthumous treatise with the same title, which analyzes the techniques of modern myth-making. Cassirer writes: "The new political myths do not

24 Pasternak, letter of 1 October 1936, ibid., 158.

${ }^{25}$ Freidenberg, 'letter to the Pasternaks, 15 December 1936, 5-6. Using Aesopian language, Freidenberg conveys the essence of her difficulties and makes her uncle understand that his family should abandon any idea of returning to Moscow (pp. 6-8, The Pasternak Trust, unpublished). 
grow freely; they are not wild fruits of an exuberant imagination. They are artificial things fabricated by very skillful and cunning artisans. It has been reserved for the twentieth century, our own great technical age, to develop a new technique of myth. Henceforth myth can be manufactured in the same sense and according to the same methods as any other modern weapon." ${ }^{26}$ The similarity between Cassirer and Freidenberg is so profound that the general characteristics of The Myth of the State can easily be applied to the ethical stance of The Race of Life. When treating reverse processes which gave rise anew to the darkness of chthonic mythologies, Cassirer referred to the Babylonian god Marduk, who had subjugated, yet not entirely destroyed, the world of darkness. However, "the mythical monsters were not entirely destroyed. They were used for the creation of a new universe-and they still survive in this universe. The powers of myth were thus checked and subdued by superior forces. As long as these forces-intellectual, ethical, artistic forces-are in full strength, myth is tamed and subdued. But once they begin to lose their strength, chaos arises again. Mythical thought then begins to rise anew and to pervade the whole of man's cultural and social life." ${ }^{27}$ Similarly, Freidenberg, rereading her diaries in 1950, stated that "the Egyptian Book of the Dead was less horrible than [her] notes" (15: 153). She compared 1937 in Stalin's Russia to the Apocalypse:

I do not know how historians will describe 1937. This was a whole year, even more: a year and a half, two years (from the second half of 1936 and to the first half of 1938) of political plague, pestilence, and flood-horrible, irresistible, and unfathomable. Its meaning was clear only to Stalin, who moved through the country like death. He undertook the merciless massacre of the population and cut off the people's head. From then on only the truncated torso remained alive. Such a version of myth was not known to mankind, even to the most savage barbarians. There were myths of Hydra, of Ruslan's head, but the horrifying picture of headless yet functioning bodies never occurred to anyone, not even to John the Divine Theologian. (6: $159-60)^{28}$

${ }^{26}$ Ernst Cassirer, The Myth of the State (New Haven: Yale University Press, 1946), 282. See also his Essay on Man (New Haven: Yale University Press, 1944) and "The Myth of the State," Fortune 29: 6 (June 1944): 165-67, 198, 201-6.

27 Dmitry Gavronsky, "Ernst Cassirer: His Life and His Work," The Philosophy of Ernst Cassirer, 34. Incidentally, Dmitry Gavronsky, an outstanding neoKantian philosopher from Marburg, was a friend of Boris Pasternak and Ida Vysotskii's cousin.

${ }^{28}$ Freidenberg refers to an episode from Aleksandr Pushkin's poem Ruslan and Liudmila. 
Не знаю, как историки будут описывать 1937 год. Это был целый год. Даже больше, полтора, два года (вторая половина 1936-го и первая 1938-го) политической чумы, моровой язвы, стихии сташной, непреодолимой и бессмысленной. Ее смысл был ясен только Сталину, который проходил по стране смертью. Он совершал процесс беспощадной расправы над населением с отрубаньем у народа головы: отныне оставалось в живых одно туловище. Такой версии мифа человечество никогда не придумывало, даже самое дикое. Ходили мифы о гидре, о голове Руслана, но никому не приходила на ум ужасающая картина обрубленных и функционирующих туловищ - даже самому Иоанну Богослову.

Like Cassirer, Freidenberg provides "an exhaustive analysis of mythical thought, uncovering the intellectual, emotional, and volitional roots upon which the myth thrives in the social life of man." ${ }^{29}$ In The Race of Life, in the chapters that follow the ordeals of her Poetics, Freidenberg depicts a pestilence that struck the university, slew many of her colleagues, and ruined the morality of the survivors. Fearlessly, she refers to her own experience, relating how the secret police tried to recruit her as an informer. Her diaries transform the genre and semantic features of the memoir into a testimony about the epoch. In her writings, the boundaries between professional prose, self-addressed meditations, factual and documentary sources, her own aphorisms, and philosophical maxims borrowed from various authors are all obliterated. Freidenberg's life and the history of her writings, as they are represented in The Race of Life, can best be summarized by the Latin saying "Habeant sua fata libeli" (books have their fate). While the adventure story of the banishment of The Poetics of Plot and Genre and its miraculous release have become known from the Correspondence of Pasternak and Freidenberg, an in-depth interpretation of the book itself has not yet been written.

${ }^{29}$ Gavronsky, "Ernst Cassirer,” 33. 
Chapter 8

\section{The Poetics of Plot and Genre: Content of the Book}

\section{A. "Dissimilarity is the Most Essential Form of Identity"}

he Poetics of Plot and Genre is a difficult text to read, and any
attempt to summarize this seminal work in less than twenty
pages most certainly runs the risk of becoming a sophomoric exercise. But since it was only after Braginskaia prepared a new annotated edition of this study that The Poetics became available for scholarly readings in the West, one feels compelled to put aside such fascinating issues as the "demystification of logos" or the "retrieval of ontological beginnings," concepts in which Freidenberg probably had an interest, but was on no occasion allowed to formulate. Instead, my overview must focus on the essentials of the book: what the book is about and how Freidenberg progresses from one proposition to another.

The Poetics starts with semantic paleontology and progresses to "paleontological morphology," very much in the vein suggested by the conclusion of the Tristan and Iseult study. It continues with a study of archaic preliterate folklore and of "that naive realism," as Cassirer used to explain, "which regards the reality of objects as something directly and unequivocally given, literally something tangible." ${ }^{1}$ In archaic folklore and ancient literature, however, one finds no such naive realism. On the contrary, Freidenberg states, in all ancient genres the basic constructive plot-lines and peripeteia of the narrative are "complicated to a point too extreme to be believed." 2 Taking the Odyssey as an example of this type of story-telling in Greek epic lore, Freidenberg writes:

The story is presented in an absolutely improbable manner and in defiance of any sense... This strange verse narrative is not a wondrous exception. We know that along with the Odyssey there existed a multitude of the same type of poemata, as they were

\footnotetext{
${ }^{1}$ Cassirer, Language and Myth, 6.

${ }^{2}$ Freidenberg, Poetika siuzheta, 39.
} 
conventionally called ("creations"). Only their plots came down to us. But the Iliad did survive; its fabula is unlike that of the Odyssey, but what completely coincides in it with the Odyssey is the form given to the language, the metrical structure, the general artistic form, the general character of the content.... All ancient civilized peoples had the same type of poemata, with a greater or lesser number of differences and similarities-in Egypt, Babylon, India, and, in part, Israel. In all these poems the fantastic, totally improbable element is mingled with close attention to reality, to life, to human society, to human character; the protagonists are plants, inanimate objects, animals, phantasmagoria (gods, heroes, monsters), the dead, as well as human beings; the place of action may be a paradisaical or otherworldly land, as well as a city, a village, a house.

Evidently, no one was interested in consciously concocting such works. Who could need, who could be the recipient of this mixture of engaging fiction devoid of sense, along with a good dose of intuition, thoughtfulness, and seriousness in approach? ${ }^{3}$

Looking into the Greek lyric genres, Freidenberg also notes that their forms do not conform to the visible world and daily practices of the people:

It is hard to imagine that in those centuries [7th-6th B.C.-N. P.] the Greek would have been unable to sing a song without a cup of wine and a bough passed to him by a fellow-banqueter along with his turn to sing; that a man in love would not have wished to speak of his love face-to-face in private without mentioning death and without tears, and, above all, without combining his own multifarious desires with a choral, monotonal song.

And yet-Freidenberg states, bringing together all of her arguments - "all these strange forms do come into being, stabilize, and function. Their fundamental and least comprehensible feature is standardization, the operation of genre stereotypes which are upheld by all poets, by all lyrists," as well as by all the great dramatists of Greece. This amazing tendency to preserve standardization in a huge variety of forms of expression Freidenberg considered to be the unique, inherent antinomic identity of ancient literature.

She was quite explicit about the subject matter and about the aims and methods of her study:

\footnotetext{
${ }^{3}$ Ibid., 40-41.

${ }^{4}$ Ibid., 43.
} 
The central problem that interests me in this study consists in defining the unity of literary semantics and its morphology. I try to demonstrate that for the explanation of differentiations there is no need to resort to the original complexity or syncretism from which the dissimilarities derive. Dissimilarity is neither a splitting off from identity, nor the result of its development (which is, in the final analysis, one and the same). Dissimilarity is rather the most essential property of the identity. It is the problem of semantics considered from its form-giving aspect. Furthermore, I intend to demonstrate that genre is not an autonomous, once and for all classified magnitude, but is intimately bound up with the plot, and therefore its classification is completely conditional. Both plot and genre have a common genesis, and they function inseparably within a system of social worldviews; each one of them, depending on the worldview, can turn into the other. In the course of the continuous development of literature, all plots and all genres acquired common features, allowing one to speak of their complete identity, despite the distinct morphological differences. ${ }^{5}$

The Poetics of Plot and Genre deals with emotive representations of collective cognitive experiences that did not always have direct sensory forms of expression and were, therefore, rendered through standardized metaphors, or as she calls them later, mental or conceived images (umozritel'nye obrazy). In this regard, The Poetics prefigures Image and Concept: it conforms to the idea of the later study insofar as image precedes and anticipates concepts. In other words, an image is not merely an envelope for concepts: if image anticipates or projects concepts, it guarantees every concept an adequate, specific form of representation. The concept is implicit in the image as the yet unexpressed inner form at every given stage of cultural development. As a representational form, image gives an individual expression to the results of the cognitive operations of a primeval collective. By exploring the survivals of such primeval image-concepts within the composition of more advanced individualized conceptual representations, Freidenberg seeks to analyze the way individual modes of collective thought arise from the archaic nondifferentiation of image and concept. It is in this sense that she calls her method of analysis genetic. Her Poetics is devoted to the demonstration of the genesis of new cognitive concepts out of archaic plots and genres, and it really shows how new cognitive concepts come into being.

In this book Freidenberg limited the scope of her investigations to the historical poetics of archaic cultural forms, demonstrating the gene-

${ }^{5}$ Ibid., 12-13. 
sis of preliterate folklore as a new form of perceiving the world and as a qualitatively new specificum, in comparison to religion. Within this strictly delimited area, Freidenberg also explained how further resemantizations of the old preliterate plots and subjects brought into being a new phenomenon-the individual poetic genres of ancient Greek literature.

While possessing its own conceptual framework and its own subjectmatter, The Poetics of Plot and Genre, in relation to Image and Concept, deals specifically with the image-component of the future Image and Concept. In other words, the latter work conceptualizes the primordial images analyzed in the former. The Poetics of Plot and Genre is Freidenberg's programmatic work, and it advances two programmatic propositions:

1) "Poetics is a discipline which deals with the law-governed regularities of literary phenomena as phenomena of social consciousness" [poetika est' nauka o zakonomernosti literaturnykh iavlenii kak iavlenii obshchestvennogo soznaniia, Freidenberg's italicsN. P.]. Poetics is both theory and concrete history of literary phenomena, for it "traces the literary process in its concrete historical conditions." 6

2) "The historical specificity of the ancient plots and of the ancient genre-formation [zhanroslozhenie] consists in the fact that all ancient plots and genres originate in folklore, that is, none of them represents an individual creation of ancient writers."7

Freidenberg then goes on to say (and, by the way, this is nothing new for her theories) that all the phenomena (poetic plots and genres) are different forms of a collective consciousness with its own long history. Through resemantization, primeval consciousness assimilates the phenomena of the surrounding world into its own categories. The aggregate result of such mental resemantization is that the primeval collective, by identifying its collective body and its life with nature, transposes what it perceived in visible nature upon its own life, thus replicating nature. ${ }^{8}$ That is, a primordial community conceives of its own life in terms of nature: the collective as a whole identifies itself with nature and repeats nature. Events in nature are experienced in a two-fold way: as a coming into view, an appearing, and as a disappearing, a departing. This pri-

\footnotetext{
${ }^{6}$ Ibid., 12; O. M. Freidenberg, Poetika siuzheta $i$ zhanra. Period antichnoi literatury. (Tezisy $k$ doktorskoi dissertatsii) (Leningrad: LIFLI, 1935), 3 (henceforth referred to as Tezisy).

${ }^{7}$ Freidenberg, Tezisy, 3.

${ }^{8}$ Freidenberg, Poetika siuzheta, 51-53 (morphology of metaphors); 221-22 (plot morphology); 254 (morphology of literary genre).
} 
mordial identification with nature Freidenberg calls the mythological metaphor. The two basic components of the mythological metaphorcoming into view/disappearing-provide representations for all phenomena of collective life. Perceived as a unity of appearing/ disappearing, the mythological metaphor is transferred onto the appearing and disappearing of the sun, the moon, and other celestial bodies; it is transferred to human birth (coming into life) and death (departing from life); the transfer is experienced as a vivification of the totem and of its collective embodiment-the tribe. Furthermore, the collective imitates the events of nature in its ritual enactments so that the entire world becomes perceived and understood as a variation, a version of the same unity of appearing-and-disappearing.

According to Freidenberg, the same mythological metaphor depicts sunrise and sunset; the alternation of day and night; of warm and cold seasons; of quickening and germination; the descent of darkness, the onset of cold and deprivation; of birth, life, and death. As she explains in her Poetics, the metaphor was preserved in the morphology of totemistic rituals, in archaic plot structures of worship, as well as in the later more complex and polysemantic collective enactments that took place in temples and on the stage platforms in city squares. Furthermore, the same unity of appearing-disappearing predetermines the structure of the agon, both the agon as the competitive battle programmed into the famous Greek national festivals, and the agon as the conflict of characters and their dialogic exchanges in ancient drama.

As we know from chapters 4 and 5 of the present study, Freidenberg postulated the unity of semantics and morphology, yet she considered the entire problem of semantics from its "form-giving" aspect. Since all paleontologists agreed that the same primordial image underlies all the motifs of a given plot, Freidenberg drew the further conclusion that morphologically all motifs repeat each other: "they are all tautological in the potential form of their existence." 9 Yet inasmuch as it is semantics that gives a particular form to them, these tautologies will always be distinguished one from another, and "one motif will always be distinguished from another, regardless of how much one tries to show their similarity." 10 The dissimilarity between morphology and semantics, between the potential form and the manifest form of the mold image constitutes the antinomic identity of all archaic motifs and their metaphorical plots.

Freidenberg's morphologic tautology denotes the tendency to preserve the standardization of plots, and the varieties of "castings" manifest the semantic polysemy of metaphors. "These primordial and mani-

9 Ibid., 225.

10 Ibid. 
fest differences [between morphology and semantics-N. P.] will always remain the result of differences in the metaphoric terminology." ${ }^{11}$ To illustrate this statement, Freidenberg refers to her basic complex of primordial metaphors: sky/underworld with its underlying image of a cyclical movement-the sun descends into the underworld, battles with its enemy, and comes out as a victor.

This constitutes the most elementary group of motifs and of plot situations: descent and ascent, combat, or rather single combat, and later-war and victory. Thus we have been operating with the concept of plot already for some time, even if it was plot in concealed form. The overall structure of plot is wholly dependent on the language of metaphors, and if this language conveys, as it does here, the image of dying/rising again (peremiranie) in the form of descents and ascents, then the plot will also take on the architectonic of more or less extended and descriptive acts of going down and coming out again. It should be clear as well that a certain figure will appear to fulfill the function of the motif: descend into hell, engage in combat with death, and rise again above the earth. Who exactly is this performer? It is still the same agent as before: the sky, the sun, or a king, a god, or the bridegroom-as-victor; or, finally, an animal, the vegetation, or a hero-the one whom we call the chorus or the protagonist. ${ }^{12}$

In the group of motifs Freidenberg described above, different varieties of metaphors convey the same primordial image; the same agent, while preserving his/her morphology, is given a different cast and conveys different meanings. In The Poetics of Plot and Genre Freidenberg continued to work on the tasks she had set herself in her earlier papers, such as "Three Plots or the Semantics of One" (1925) and the study of the plot of Tristan and Iseult. In the Poetics, however, Freidenberg limited herself neither to defining the semantic clusters on which this or that group of plots was based, nor to outlining different series of plot transformations. Instead she made morphology a constituent part of the semantics of cultural forms.

\section{B. Shifts in Meaning/Structure and in Image/Concept Correlations as the Main Operational Principles in the Archaic Semantics}

The Poetics also continued the ideas first proposed in the "Semantics of the Structure of the Puppet Theater." The latter, however, traced only

\footnotetext{
11 Ibid.

12 Ibid.
} 
one series of semantic identities and discussed only the roles allotted to a doll (a man-made article viewed as the representation of a god, a human being, and the dead), whereas the Poetics started from "the beginning of all beginnings": it focused on archetypal, or, in Freidenberg's professional lexicon, "mythological metaphors." The mythological metaphors of appearing/disappearing were construed as underlying the "elementary acts of eating, life giving, weeping, and laughter." 13 Through different images the archetypal metaphors conveyed the same sum of primitive meanings extracted by the collective from nature. The archaic semantics of eating, for example, was derived from the enactment of the totem's appearing (the setting up of the tribal deity) and its disappearing (the removal of the deity.) The semantics of weeping was derived from disappearance (the death, the devouring) of the totem; weeping accompanied its death, laughter-its revivification. In wedding ceremonies, the bride and the groom were viewed as male and female deities who appear in the temple like the brightest celestial bodies and thus make themselves visible to all. Hence, the wedding ceremonies provided reenactments of the metaphor of appearing, of coming into sight, of beginning a new life. In later centuries, the Christian Eucharist reenacted an archaic ritual of eating the body of the tribal totem. ${ }^{14}$

If Veselovskii argued that syncreticism represented a stage of cultural development in which different forms of experience were merged and not yet distinguished, then Freidenberg insisted that archetypal metaphors existed side by side. This parallelism of archetypal metaphors provided parallel realizations of the same integral meaning. Yet metaphors were not seen as equal or comparable, because the primeval mentality was not yet aware of the relative properties of objects that would make possible the comparison of one thing to another. Six years after the publication of her Poetics, Freidenberg undertook the semantic and morphological analysis of epic simile. ${ }^{15}$ There she demonstrated that the archaic epic similes are all structured as elaborate depictions of scenes. The first part of the scene (a cultural survival of archaic totemistic images) functions as a plot-line in its own right, and at the same time organizes the narrative and provides the point of view from

\footnotetext{
13 Freidenberg, Tezisy, 5.

14 Freidenberg, Poetika siuzheta, 59-62.

15 Freidenberg, "Proiskhozhdenie epicheskogo sravneniia (na materiale Iliady)," Leningradskii gosudarstvennyi universitet. Trudy iubileinoi nauchnoi sessii. Sektsiia filologicheskikh nauk (Leningrad: Leningradskii gosudarstvennyi universitet, 1946), 101-14. The author's footnote informs us that "the work was written during October-December 1941 in Leningrad."
} 
which the second part of the scene is depicted; here the main actors are already human heroes. ${ }^{16}$

Well versed in cultural anthropology, Freidenberg was fully aware of the fact that "representations," "transferal processes," "reenactments," "metaphors," "semantic clusters," "laws of participation," etc. had no place in primeval consciousness. Thus she wrote:

Let us imagine that consciousness produced the transference of one phenomenon upon another, and thus metaphorized it; in reality consciousness did not do that, and initially there existed no metaphors at all-metaphor is simply our own term for denoting real historical features of primitive thinking which interpreted objective reality. Thus, metaphor is an image rendered precise (metafora-utochnennyi obraz). Metaphor translates the impersonality of undifferentiated mental representations into the language of the distinctive character of real-and, once again, external-phenomena. In every metaphor we are dealing with a contradictory simultaneity (a simultaneity which cannot be dissociated and designated chronologically) of the generic commonality of an image and its particular concrete specificity. An image is given a particular form by means of particular, completely different, concretely applied metaphors; the metaphors are, therefore, semantically identical, but morphologically they are always differentiated from one another. ${ }^{17}$

Shifts in meaning/structure and in image/concept correlations form semantic clusters and designate a progression from one stage in the development of society to another. Every stage of the relations of production in society represents its own context of meanings, and the comprehension of new contexts is accomplished through semantic clusters. Thus, what underlies the development of synchronic and diachronic phenomena in culture are changes in the morphologic structure of metaphor, the accumulation of new semantic overtones, and the polysemy of the clusters. Semantics and morphology, thus, perform three functions diachronically: they accumulate, preserve, and modify collective memory. The human acquires new categories of consciousness and a broader knowledge of the world in two ways:

${ }^{16}$ Among contemporary scholars, Steven H. Lonsdale in his Creatures of Speech: Lion, Herding, and Hunting Similes in the Iliad (Stuttgart: B.G. Teubner, 1990), 9, 103-10, also supports the idea of two parallel scenarios-one of animals and the other of human life-constituting the form and contents of ancient Greek similes.

${ }^{17}$ Freidenberg, Poetika siuzheta, 51. 
One, through a change in the relationships between what was perceived by the senses and what was signified by actions and words. What follows is the translation of sense perceptions into signs which develop into primitive performances or spectacles; and elementary verbal expressions in those performances acquire the status of the simplest concepts. Thus the perceptual-conceptual transformations affect and change the old structures from within.

Two, the old structures can be used to name and interpret new aspects of collective experience. In this case, the translation of transference is to be understood as the incorporation of a new historical reality into a cultural context previously unknown to the consciousness of an ethnic or social group.

The constituent elements of the new cultural context obtain their specific meaning through the redirection of old morphologic functions and the restructuring of old symbolic forms. In this redirection of the relationship between the functions of morphological structures and the function of semantic contents Freidenberg discovered the model for explaining the genesis of archaic literary plots and genres. What needs to be stressed, however, is that she never treated primordial images and archetypal metaphors as the "embryos" of new genres. In her view, all the archaic genres-epos, lyric, and drama-have their origin in the same semantics. Yet the existence of this single semantic base does not guarantee that all the specific literary genres (epos, lyric, drama) will necessarily come into being in any ethnic community. To clarify her proposition, Freidenberg poses a hypothetical question: what would have happened if lyric poetry had remained unknown in Greek literature? After all, epic poetry was unknown in Hebrew literature, and drama was unknown to ancient Babylonians and Egyptians. Freidenberg's answer is that if this were the case in ancient Greece, then the lyric would still not be known as a literary genre: rather, it would exist "in the form of myth, ritual, tradition, in the form of a festival; as a folk legend, a tale, a song." ${ }^{18}$ In other words, instead of becoming lyrical poetry as a literary genre, the lyric would exist as the lyric mode which manifests itself in different varieties of laughter, keening, invocation. Lyric as the lyric mode would provide the social process of assimilating reality with new modifications and combinations of perceptualconceptual transformations. What this indicates, Freidenberg insists, is that literary genres are brought about by internal antinomies: the perceptual base of literary genres is "an antiliterary material (antiliteraturnyi material), which has to resemanticize its own self and redirect its own functions in order to become literature." ${ }^{19}$ This

\footnotetext{
18 Ibid., 133-34.

19 Ibid., 134.
} 
categorical conclusion which summarized the relationship of plot and genre made Veselovskii's evolutionary models of syncreticism inapplicable to Freidenberg's interpretations.

In the pre-literate period as well "metaphors, semantically identical yet externally diversified, give form to the same worldview in its essence (oformliaiut i tut vse tu zhe samuiu mirovozzrencheskuiu sushchnost'), except that its objectification takes on a rhythmic-verbal form."20 The metaphors of appearing/disappearing semanticized the recurrence of natural phenomena. The metaphors themselves had two rhythmicized forms of manifestation: verbal acts and non-verbal physical actions. "In the consciousness of society, actions and rhythm (deistvovanie $i$ ritm), as the simplest biological elements, are immediately subjected to interpretation in the consciousness of human society, and thus are transformed into two parallel worldview forms." ${ }^{21}$ The physical acts of crying and laughter, for example, were semanticized as lamentations and invocations and were enacted collectively under the guidance of the tribal leader, the exarchos, whose movements and exclamations, repeated by the tribesmen, produced the primary rhythmical patterns of archaic folklore. Adducing examples from the history of classical prosody, Freidenberg shows that the basic elements of versification derived from the names of body parts: podos means "foot" and "a metrical foot"; kolon means "a member of the body" and "a member or section of a rhythmical period." Like the simple signs of kinetic speech, rhythmicalverbal acts named and identified particular phenomena.

The word is terse and rhythmic. Initially it consists of names alone, and then of repetitions of names: it is effectively paralleled by bodily movements. A terse rhythmical unit gives the verbal expression its primary musical form: this is the short verse, accompanying the movement of the foot, which combines with other similar verses, and produces either slowed-down, drawn-out, mournful rhythms, or quick, lively dancing rhythms (pliasovye ritmy). Thus the tempo itself acquires a specific semantics: the 'slowing down' is linked to sorrow, to death, while the speeding up is linked to joy, to life."22

20 Ibid., 133.

${ }^{21}$ Ibid., 112, 323 n, 343. Freidenberg shared the hypothesis (strongly supported by Veselovskii and Marr) that "kinetic speech" (repetitions of gestures and nondifferentiated auditory signs) preceded verbal communication.

22 Ibid., 122-23. 


\section{Further Examples of "the Heteromorphism of the Forms of Being"}

By the 1940s, Freidenberg sums up the results of her observations in the formula "the concept is created by the image." This formula is given the status of "the main law of semanticization, which is also considered as the main law of producing forms" in semantics and in morphology. ${ }^{23}$ In her papers of the 1940s, Freidenberg presents further examples of "the heteromorphism of the forms of being" (raznomorfnost' bytiinykh form). She defines the perceptual-conceptual vectors joining the center (the sun in the sky) with other bodies arranged around it on different planes: the heavenly and the earthly spheres correspond to an arch or the gates of the city as their heteromorphic modifications; the indication of height on a vertical axis is perceived as a milestone, a frontier post, a pillar, a column erected in the center of the city; on the horizontal earthly plane the arrangement is perceived as the center of a settlement, which may be a market place, an arena, a platform in the middle; and, finally, heaven and earth correspond to the subterranean sphere, the underworld. ${ }^{24}$

Today, almost sixty years after The Poetics of Plot and Genre was written, some may believe this work to retain only historical value, since many of Freidenberg's innovative ideas have been introduced into the field by other scholars. However, such a presumption is not in the least correct. Freidenberg's unsurpassed innovations may be seen in her new classification and regrouping of data obtainable from the historical poetics of ancient times and in her monogenic interpretation of folklore, the verbal arts, and poetics as individual forms of one collective worldview. Her genetic method provides an exceptionally and, perhaps, uniquely unified insight into a wide variety of discrete phenomena by revealing the one archetypal meaning that underlies the variability of cultural representations and manifestations:

The multi-level polyvariant nature of the metaphors (which are non-derivable from each other) produces an externally variegated picture which is unified from within by one and the same meaning. The particular forms given to these polyvariant metaphors are constituted by parallel rhythmic-verbal, actional, material-objectival, and personificational sedimentations of one and the same semantic interpretation of the world. ${ }^{25}$

The constituents that our modern mind is accustomed to distinguishing within literature (such as rhythm, word, action, thing, personage) all go back to different forms of understanding the meaning of reality and

23 Freidenberg, "Vvedenie v teoriiu antichnogo fol'klora," 45.

${ }^{24}$ Freidenberg, "Semantika pervoi veshchi," 16-22.

${ }^{25}$ Freidenberg, Poetika siuzheta, 109. 
result from the same process of metaphorization. "Their structure is constituted in the same metaphoric way as any system of images. What subsequently becomes lyric poetry, drama, etc. is a variation of laughter, weeping, vituperation, invocation, etc., in as much as it is a paraphrase, a new figurative expression of one and the same meaning ... i. e., one and the same meaning of reality." 26

To reconfirm the above philosophical claim, Freidenberg insists: "Food, birth, death-they are not elements of future literary genres and plots, and it is pointless to search for them and find them there; they are metaphors which have given a form to imaged ideas about food, birth, and death. These metaphors, varying and recombining, give form to literary genres and plots and constitute the morphological parts of them." 27 Subsequently, in chapter 2 of her Poetics ("Forms of the Primitive Worldview"), she demonstrates how different emotional and communicative forms came to convey new themes and meanings.

In Freidenberg's analyses one never loses sight of the connection of literary genres and plots with "the parallelism of perceptual representations" and "the heteromorphism of the forms of being." She stated unambiguously that the social values expressed in collective representations can be objectively described and evaluated from within through the study of their structures. Freidenberg's "semantics considered from its form-giving aspects" shows the redirection of functions within the intuited and perceptual view, on the one hand, and within the conceptual and mental constructions, on the other. Thus her genetic analysis examines both the morphogenesis and the semantics of different speech genres, such as rhythmical invocations, elevated forms of praise and low forms of abuse. For instance, the fixed formulae of the komos, which consisted of verbal abuse chanted in a rhythmical pattern, served to elicit the fertility of the newly-weds and to protect them from poverty. Freidenberg interpreted the fixed forms of vituperation in the komos as metaphors which translated the "impersonality of the undifferentiated mental representations" of death, sterility, and starvation "into the language of the distinctive character of the real," that is, into images which now are all given particular and specific forms. Similarly, such different forms as the paeon (a loud and joyous song of triumph), the dithyramb, the elegy, and the lyrical song were structured from within by patterned sound repetitions (alliterations, rhymes, and rhythms). Different forms of discourse (dialogue and agon in comedies and tragedies) as well as of narration and storytelling (pithy monologic sayings, such as the gnomes,

${ }^{26}$ Ibid., 109-10.

27 Ibid., chap. 1, pt. 2 of Freidenberg's Poetics, "The Primitive Worldview" [Pervobytnoe myshlenie, 50-111], is composed of the sub-chapters "Metaphors of 'Food,"” "Metaphors of 'Birth,"” and "Metaphors of 'Death.'” 
riddles, and prophecies) all owed their polyvariant nature to a common folkloric origin, yet each, located within its own time-space framework, now functioned in agreement with its new, individual cultural scenarios.

\section{Forms of Comedy and Tragedy in Their Dialectical Relation to the History of Communal Perceptions}

In the part entitled "The Literary Period of Plot and Genre" Freidenberg begins to work out the specific features of the comic and of the tragic in the plots and genres which subsequently became ancient comedy and tragedy ${ }^{28}$ In the context of literary plots and genres she returns to her idea of "a contradictory simultaneity of the common generic nature and its particular concrete specificity," which now takes on the form of a correlation between mode and genre.

Ancient tragedy is of the same social age as ancient comedy. But as a literary genre tragedy is created prior to comedy. The archaization of the forms of tragedy seems to indicate a chasm separating tragedy and comedy, and yet comedy is not as ancient as tragedy. The crucial difference is that the class countenance of comedy specifies precisely that in comedy which is most archaic and no longer vital. ${ }^{29}$

The Poetics of Plot and Genre provides an analysis of the forms of comedy and tragedy in their dialectical relation to the history of communal perceptions, worldviews, and modes of thinking. Considered as modes of thinking, the tragic and the comic "have their own class genesis and are determined by their own historical conditions. The tragic and the comic are, therefore, concepts which change their content at every new stage in the development of thinking." ${ }^{30}$ This rather conventional Marxist statement, however, constitutes only one part of Freidenberg's antinomy of mode and genre. In fact, on the same page of her study she explains that in the process of development from pre-literary to literary thinking, "just as the tragic, the comic, once it becomes stereotypical, begins to acquire its own special genre characteristics, its own special dramatic personae, a special selection of material objects, a special vocabulary." As Freidenberg explained, that which constituted the content of the tragic, could eventually become the subject for a comedial

${ }^{28}$ See also pts. 4, 6, and 7 in Image and Concept (286-328, 345-71, 372-622) and "Komicheskoe do komedii (k probleme vozniknoveniia kategorii kachestva)," Mif $i$ teatr, 74-127.

${ }^{29}$ Freidenberg, Poetika siuzheta, 266.

30 Ibid., 269.

31 Ibid. 
representation. While the modes of perception were interchangeable, literary genres conveyed qualitative distinctions, and in this sense ancient comedy and tragedy functioned as fixed and stable literary categories. The "potential forms" of the tragic and of the comic were capable of manifesting their underlying deeper identity, but comedy and tragedy, as culturally defined aesthetic forms, were identified as different genres. ${ }^{32}$ In comedies universal concepts were rendered through "low-brow" images. The outward features of the characters' masks and costumes gave graphic expression to the metaphors of sex, bodiliness, and gluttony. Where tragedy represented passionate suffering, comedy showed sensual lust; where tragedies and epics dealt with Asklepios (the divine healer and the ideal image of the physician), comedies, farces, and mennipeas presented tricksters, cheaters, liars, and mountebanks. The vulgar, mimetically "realistic" themes of the comic genres all had their elevated counterparts. Since comedy and tragedy originated in contrasting systems of values, the identical components were presented as pairs of opposites.

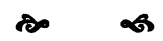

The definition of metaphor which Freidenberg proposed in The Poetics of Plot and Genre called into question both Veselovskii's theory of syncretism and Marr's theories of "the four elements" and of development by stages.

I defined metaphor as a concretely functioning image; all the metaphors of one and the same image are identical in meaning. They differ only formally. This simple theory resolved all the difficulties of the formation of primary metaphors, and Khona [Frank-Kamenetskii-N. P.], who specialized in the study of metaphor, following now Veselovskii, now Marr, now Cassirer, immediately appreciated what I myself did not see. He told me, laughing, how he expressed his bitterness about his failure to Dora [his wife-N. P.] and how she exclaimed naively: "Why could not you think up such a trifle, and she could?" (5: 121)

The Poetics draws its data from different spheres of communal experience. The unified picture of the universe does not lose its variegated and polyvalent character. The book presents long inventories of material things: food (corn, beans, water, wine, porridge, and meat);

32 To emphasize the difference between her paleontological and the neoHumboldtian interpretations (Potebnia), Freidenberg uses the term "potential form" rather than that of "inner form" when she deals with "morphological structures." The distinction underscores the difference between the epistemological and etymological origins of the concepts. 
objects required in various kinds of performance (if corn functions as a signifier of the powers of Demeter and Persephone, showering the newly-weds with corn elicits fertility, and the corn seed buried in the earth provides metaphors for life, death, resurrection, and immortality). Similarly, in folklore and in folk medicine, a bean brew provides a meal which raises sexual potency; in fortune telling, dividing beans by color or distribution provides a cryptogram for one's future; in the Saturnalia, beans represent the motifs of solar and chthonic plots; and in medieval carnivals and seasonal mockery plays, the King of the Bean becomes the ruler and protagonist of a comic performance. Ancient agorae (city squares and market places), as well as the interiors of private houses, the crypts of temples and sarcophagi are seen as "material-objectual metaphors" (veshchnye metafory), and thus provide subjects for conceptual metaphors. Conceptual metaphors, are, in their turn, recombined into semantic clusters. The manifest dissimilarities of objects are in no way played down in the Poetics, since the semantics of plots and genres is viewed as the form-giving capacity of the human mind. It is in this way that Freidenberg succeeds in demonstrating that "dissimilarity is not a dissociation from identity, nor the result of its evolution." 33

Freidenberg's theory claimed that the reconstitution of symbolic forms and the redirection of functions within the categories of cognition provide new representations of reality. The theory not only described the mechanism of cultural memory, but also proposed a new perspective on the typology of literary development. The culturological framework of Freidenberg's Poetics of Plot and Genre anticipated the main premise of Cassirer's philosophy of culture in his Essay on Man (1944): "History will always keep its place and its inherent nature in the organization of human knowledge"; while "art turns our empirical life into the dynamic of pure form, history molds the empirical reality of things into a new shape and gives it the ideality of recollection." ${ }^{34}$

In a study written during the 1930 s, when the "unity of form and content" and the supremacy of matter over idea were made into a shibboleth, Freidenberg had the courage to demonstrate that "dissimilarity is the most pertinent characteristic of identity." Her thesis that both genre and plot function inseparably within the system of individual forms of social consciousness postulated a "semantic law" which determines the interdependence of "the material basis, relations of production, forms of thought along with its contents" (5: 130). From Freidenberg's standpoint, metaphors infused the material world and the social universe of primeval men with conceptual meanings. Instead of a

${ }^{33}$ Freidenberg, Poetika siuzheta, 12.

34 Konstantin Reichardt, "Ernst Cassirer's Contribution to Literary Criticism," The Philosophy of Ernst Cassirer, 664. 
sociological analysis of reality Freidenberg proposed a methodology for analyzing forms of communal-social thinking. 
Part 5

The Siege of Leningrad and Its Aftermath

Еще там

Наши лежат погребенья лишенные трупы; о нашей

Смерти не сведал еще ни один из родных и из ближних Наши кровавые раны еще не омыты, еще нас

........... никто нас оплакал, и почести нет нам.

Гомер, Одиссея, перевод В. Жуковского 
Chapter 9

\section{The Siege of a Human Being and the Technique of Modern Political Myths}

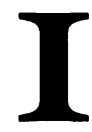

n The Race of Life, which includes "Recollections on My Own Self," Freidenberg loves to speak about the personality traits displayed by her contemporaries in their everyday contact with her. However, at the interpretative level, her emphasis on the homey aspect of these portrayals immediately becomes a component of a broader type of narrative. The stories and personal tales included in The Race of Life are never neutral with regard to the fate of civilization and scholarship during the epoch of Stalinism.

Impetuously fearless and demanding in her scholarship, Freidenberg expected from everyone alike the same level of rigor. Exaltation, self-absorption, stubbornness, and the traits she herself designated as "iurodstvo"-personal features of a holy fool-these characteristics clashed within her. Understanding these internal contradictions was particularly difficult for those around her. With good reason, Freidenberg's students and colleagues gave her the nickname "Archbishop Avvakum." The nickname applies equally to her personality and to her idiosyncratic style of writing.

A seventeenth-century preacher and religious teacher, Avvakum was deeply involved in the troubled fates of his coreligionists, the Old Believers. But sympathetic as he was to their ordeals, Avvakum demanded from his congregation unreserved submission to the moral rigor of his teachings and adherence to his standards of everyday behavior. The indivisible combination of spiritual exaltation and everyday unpretentiousness in equal measure defined the biography of Avvakum and the style of his writing, in which traits of the theological treatise, the secular story, the Christian saint's life, autobiography, and memoir were interwoven. The thematics of his stories about "voyages on the sea of daily life" were informed by the hagiographical tradition and biblical literature, which molded Avvakum's worldviews, but his ideological and confessional standing in the "old faith" gave rise to a new realization of his own personality and of those who interacted with him. As many scholars have indicated, in Avvakum, autobiography is organized into a 
mythic structure within which an individual way of life is given the prevailing, and quite an unusual, structural function. His Life reads as a valuable historical document, though the portraits of Avvakum's contemporaries in it are often factually inaccurate. ${ }^{1}$

Freidenberg's memoirs, where entries in the intimate diaries speak of her sense of history and superpersonal semantics, are similar. Many of the discrete events of her personal life are built into her depiction of Yezhovshchina, "a period of dreadful political trials, arrests, and banishments." 2 Thus in volume 6 of The Race we read of the arrest of Musia, her sister-in-law and Sasha's (Alexander Freidenberg's-N. P.) wife, who was, allegedly a mistress of the director of a military plant, accused of espionage in 1936; of Sasha's unwillingness to cooperate with the interrogator to denounce his unfaithful wife, of his arrest in 1937 and death in the beginning of 1938; of the sudden death of I. G. FrankKamenetskii, who fell victim to a car accident in 1937; and of the hounding of Boris Pasternak for the poet's unwillingness to sign death sentences against the defendants of the political trials.

In Freidenberg's memory the terror of the thirties gave way without interruption to the horrors of the war and the blockade. She filled up blockade notebooks, entitled "Recollections on My Own Self," "A Wreath of Dill,"3 and "The Siege of a Human Being" ("Osada cheloveka"), in the same years that Leo Spitzer, the famous classicist scholar who had escaped Hitler's Nazi-camp in Germany, published in the United States a discussion article "Geistesgeschichte vs. History of Ideas as Applied to Hitlerism." ${ }^{4}$ Spitzer, who was acclaimed by René Wellek for "the peculiar combination of lexicography and history of

1 The Archpriest Avvakum (1620-1682) was the leader of the Old Believer schism in the Russian Church. Avvakum's autobiographical account of his own life uses the conventions of the saint's life (zhitie) to describe his own sacrifice for the sake of his religious ideals. See Priscilla Hunt, "The Structure and Function of the Autobiography of the Archpriest Avvakum," Ricerche Slavistiche 23 (197576): 57-70.

2 In 1936-38 N. I. Ezhov was the People's Commissar of Internal Affairs. "The chief of the secret police," in Freidenberg's account, he "was always referred to by such Homeric epithets as 'The Iron Commissar' and 'Stalin's Comrade in Arms." Mossman, Correspondence, 175.

${ }^{3}$ For the figurative meaning of this expression, see the preface, 2 . In her memoirs, Freidenberg reaccentuated the statement: "Dill is another story, fresh dill with vitamins! From early in the morning the radio harangues the people of Leningrad to have a private kitchen garden! Any Leningrad dweller now will pay 2,000 rubles for a bunch of dill, anyone will steal and sell for 20,000 the dill from his neighbor's kitchen garden" (8: 97).

${ }^{4}$ Leo Spitzer, "Geistesgeschichte vs. History of Ideas as Applied to Hitlerism," Journal of the History of Ideas 5 (1944): 191-203. 
ideas" in his studies, was also moving from historical semantics toward the semantics of culture. ${ }^{5} \mathrm{He}$ too investigated particular signs of the phenomena inseparably linked with the overall emotional and conceptual climate of the era. Speaking of the different "isms" that defined the general climate of Hitlerism, Spitzer names the union of nationalism and socialism (National-Socialism) in domestic and foreign politics; the collectivism touted by Hitler ("closeness to the people"); messianism (the deification of the leader, literally "the principle of leaderism"); antiintellectualism; pagan fetishism; the principle of Realpolitik (or political realism); racism; Machiavellianism; and finally the perception of death, murder, violence, and the terrors of life as norms. ${ }^{6}$ Stalinism in The Race of Life is conceived in this sense as a cultural calque of Hitlerism.

Freidenberg's concentration on Stalinism is particularly apparent in the blockade entries, where there is virtually nothing written about German fascists, Hitler's armies, and their atrocities. Aware of Hitler's strictly executed program to exterminate the Jews, Freidenberg, a Jew by birth, repeats from chapter to chapter that Stalin's order to defend Leningrad "to the last drop of blood" is just as horrific a policy of human annihilation as Hitler's genocide, and uses the words "executions," "torture chambers," "concentration camps," and "siege" only as applied to life in the Stalin era:

It frequently came to my mind: who is more relentless-those who locked people alive in the death box or those who shot and killed? Hong Kong was surrendered because of a shortage of drinking water. Cities and regions yielded to the enemy when food supplies ran out. But with us! No peoples' torment, neither pestilence, nor starvation would ever urge our authorities to surrender the city, to parley, to negotiate, to offer a victim any help. Here there operated a common law of trampling down a human. This law was called valor, prowess, heroism of the besieged, who voluntarily, it was said, sacrificed their lives. (9: 71)

The blockade of the war years reinforced with new cruelty the siege waged by Stalin on the people. The introduction of different categories of ration coupons for foodstuffs established a hierarchy in the system of starvation and death, making access to food, heat, light, and survival a Party and governmental privilege. Freidenberg's diaries serve as documentary evidence that Stalin's siege on humanity, combined with Hitler's blockade, led to changes of a biological and spiritual nature,

\footnotetext{
${ }^{5}$ Renè Wellek, preface to Classical and Christian Ideas of World Harmony: Prolegomena to an Interpretation of the Word "Stimmung," by Leo Spitzer (Baltimore: The Johns Hopkins Press, 1963), vi.

${ }^{6}$ Spitzer, "Geistesgeschichte," 194, 198.
} 
changes in the ethics and psychology of the Soviet people. But even when the principal, biological laws of human existence were seemingly suspended, the punitive machine of Stalinism continued to work with all its former cruelty. Citizens of Leningrad dying from starvation were arrested and tortured by interrogations. There appeared new pretexts for arrests: the distribution of defeatist rumors, fluency in the German language, and knowledge of German culture were treated as proclivity to espionage. Viktor Zhirmunskii was arrested because in his study he had a map of St. Petersburg printed in German; Gukovskii was said to be a food profiteer. These malicious rumors actually affected people, and Freidenberg believed that the slanderous fabrications about Gukovskii were not groundless. ${ }^{7}$ Those who did not die of starvation were sent to dig trenches, to their death under fire, or were forced into daytime duties and night watches.

By the graphic naturalism of her entries, Freidenberg exposes the falsely patriotic emblems of the official press. The physicality of her descriptions of diarrhea, filth, stench, rotting sewage, and defecation frozen rock-hard in the wintry streets contrasts with the official myth of the moral immaculateness, political purity, and cleanliness of the simple Soviet people. Freidenberg calls those dying from starvation "golodaiushchie" (the hungry), but not "dystrophics." She understands that the use of the neutral medical term is dictated by an ideology that imposes a taboo on truth and thus breeds in the human mind an indifference to death. She vehemently rejects an industrial exhibit which displays goods produced from man-made materials and natural substitutes, since for her the exhibit is arranged as self-promotion of a lie. Even the new women's fashions in the war years are interpreted as a substitution of a lie for truth, and a compensation for what had been taken away. The starving should appear to be buxom beauties, with padded, boldly squared shoulders and stout busts, or young girls with luxuriant blond hair.

An erudite scholar, well versed in Cassirer's philosophical works, Freidenberg pursues the connections between the collective consciousness and the linguistic forms in which the consciousness of an era is expressed. She develops an analysis of the language of the Stalinist period and consequently moves to the semantics of cultural forms. The letters of her high school friend Mimi Voevodskaia, in which she talks about the

\footnotetext{
${ }^{7}$ Freidenberg described the wave of arrests at Leningrad University in late December 1941 (7: 46-47). Lidiia Ginzburg compares the attacks of "those" (the Nazi airplanes) and "these" (the NKVD): "These were not so prompt. It was believed that after four in the morning these do not usually come, and from four o'clock on till the evening a human being imagined himself to be in safety," Chelovek za pis'mennym stolom (Leningrad: Sovetskii pisatel', 1989), 590.
} 
death of her beloved, an officer in the Polish Army, permit Freidenberg to surmise that the organizers of the catastrophe at Katyn were Stalin and his clique. Her memory of the Tukhachevskii case makes her realize that in 1943, using the same hackneyed pattern, the Kremlin fabricated the accusation that General Wladyslaw Sikorski, the head of the Polish Government in Exile, collaborated with the Fascists. Seeing reports in the State's central newspapers of the opening of the Third Pan-Slavic Meeting in Moscow and comparing this event with the dissolution of the Third International (9 and 15 May 1943), Freidenberg gives a penetrating reading both of the religiously colored language used during wartime and of the coarse, political camouflage which set up Stalin-era panslavism as the true image of the international brotherhood of the Slavic nations (9: 86-90). Hitlerist propaganda put the biblical word "chiliasm" back into circulation, attaching to it the new semantic meaning of the thousand-year reign of the Third Reich. Stalinist propaganda elaborated an entire lexicon of messianic terms and fixed epithets with the same content: the Genius of All Times and Peoples, the Great Helmsman, the Light of the World, World-Wide Historical Victory. Like leitmotifs, these epithets of Stalinist cultural politics, direct calques of Hitler's Kulturpolitik, connect the themes of the war and post-war volumes of The Race of Life.

With the end of the Second World War the West learned from many sources how Hitler's system operated in the area of ideology. These sources include the works of Victor Klemperer, a German philologist, by descent half-Jewish and half-German, who recovered after confinement in a Judenhouse in Dresden to publish a book on the language of the Third Reich, LTI (Lingua Tertii Imperii). ${ }^{8}$ Klemperer and Freidenberg noticed identical examples of newspaper rhetoric during Fascist and Stalinist times. They name one and the same fixed epithets applied to everything "positive": the world's best tennis players (in Germany), the world's best soccer and chess players (in the U.S.S.R.). Both here and there "purges" were carried out, and where the "Beloved Father and Leader" Hitler ruled with "a strong rod," Stalin equipped himself with "a rod of iron." The postwar program of punitive operations elaborated

${ }^{8}$ Victor Klemperer. LTI. Notizbuch eines Philologen (Halle/Salle: VEB Max Niemeyer, 1957), 4, 226-36, 171. Freidenberg was not familiar with Klemperer's writings, because the first edition of LTI (published in East Germany in 1946) was not available in the Soviet Union.

${ }^{9}$ For those familiar with German and Russian, the origin and the political transference of metaphors in Hitler's and Stalin's lexicons is quite apparent: “der eiserne Handschuh" (zheleznaia rukavitsa, from Goethe's medieval knight Götzder eiserne Hand), and "ezhovye rukavitsy" (from Stalin's "Iron Commissar" Ezhov). 
by the Soviet ideological apparatus was, in essence, a borrowing: as early as 1942 the publication Bolschewistische Wissenschaft und Kulturpolitik (a series on higher education of a district in East Prussia) proposed the problems "Linguistics in the Soviet Union," "Philosophy and Psychology in the Soviet Union," and "The Bases of Soviet Pedagogy." Also discussed was the depiction of "The Spiritual Life of Contemporary Soviet Georgia in the Mirror of Literature." 10

Freidenberg's discrediting of falsely heroic myths distinguishes her memoirs from the avalanche of "siege" publications in the Soviet press as well as from the small number of books written by Western correspondents. In the latter case a comparison of Freidenberg's text with Harrison Salisbury's 900 Days: The Siege of Leningrad deserves particular attention. Inasmuch as many of the blockade survivors whom Salisbury interviewed lived in a house belonging to the Writers' Union on Griboedov Canal, two blocks from the place where Freidenberg lived, it would be natural to expect some agreement between his information and the material in The Race of Life. There is none: the facts recorded by the American journalist from prominent figures in the Union of Soviet Writers-Vera Inber, Vsevolod Vishnevskii, Vera Ketlinskaia, and others-were all carefully selected in advance and adapted to the structure of the patriotic myth. ${ }^{11}$

In 1943 Freidenberg was hired by the Central State Archive of History to provide source material for the collection "Heroic Women of Leningrad." As she wrote, she was more interested in interviewing "little people" rather than the great.

The little people reeked of Soviet heroism, of an amazingly impersonal heroism. They were modest, terrified, and they had learned modesty and patriotism by heart as if for an exam.... Some lives emanated uncensored tragedy. I learned the horrible truth about the work of the female members of the Board of Public Defenders during the siege. A story about the defenders who walked over the slippery ice of the Neva to prisons where people were dying by the hundreds. This horror story turned one's heart to ice, but nobody dared to write down the truth. People told me many unbelievable stories. A remarkable tirade

${ }^{10}$ Bolschewistische Wissenschaft und "Kulturpolitik," ed. Bolko Freiherr von Richthofen (Königsberg and Berlin: Ost-Europa Verlag, 1942).

11 Harrison E. Salisbury, 900 Days: The Siege of Leningrad (New York: Harper \& Row, 1969), 251-53, 363-65. Only the young writer Pavel Luknitskii, who lived in the same building, No. 9 Griboedov Canal, was brave enough to describe Leningrad under the siege as "the city of the white apocalypse, where humans fed on humans and the very water which they drank carried the sweet stench of human corpses." Ibid., 481. 
was uttered by a worker of the People's Committee of Internal Affairs from the Institute of Meteorology, Tesakova. "Everything is fine, but why is it impossible to tell the truth about Leningrad? The heroism of our women would reveal itself clearly only if we were allowed to tell about cannibalism, about staying for 20 days together with 5-6 dead bodies in one room, about the arms and legs we dug out of the snow, about dead children in rubbish heaps, about everything we suffered through that kills the soul." (10:46)

The whereabouts of the material collected by Freidenberg for the archive are currently unknown; they may have been removed from the stacks during the Popkov Leningrad trial. Some of the women interviewed by Freidenberg maintained their own diaries as well, ${ }^{12}$ and during the 1980s-1990s, following Ales' Adamovich and Daniil Granin's $A$ Book of the Blockade, numerous oral histories of siege survivors have been published containing episodes similar to those mentioned by Freidenberg and her informants. ${ }^{13}$ There are also the famous Notes of the Besieged by Lidiia Ginzburg and Dmitrii Likhachev's memoirs How We Stayed Alive. ${ }^{14}$ Nevertheless, a comparison of The Race of Life to the memoirs of these survivors of the blockade makes the volumes grouped into "The Siege of a Human Being" a challenging exception to the entire class of war texts.

It is neither the tenaciousness of Freidenberg's memory, nor the facts she remembers, nor even the emphasis on atrocities and ordeals that make the difference so notable. Rather, the notion of a communal spirit, a concept expressed grammatically by the pronoun "we," is not to be

12 Freidenberg interviewed an artist, Anna Petrovna Ostroumova-Lebedeva, whose wartime diaries were included in the second volume of her memoirs Avtobiograficheskie zapiski (Leningrad and Moscow: Iskusstvo, 1945), and a piano player, Mariia Iudina, who visited Leningrad and gave concerts there in late February 1943 and in June-October of the same year. She also interviewed an opera singer, Sof'ia Preobrazhenskaia; an actress and memoir writer MichurinaSamoilova; a school teacher and party activist, Maria Kropacheva (her notes of a journalist, "How Do We Work" [July 1942-January 1943], are held in the Manuscript Department of the St. Petersburg Public Library); and Anastasiia Iakubchik, professor of chemistry at LGU and an old friend of OstroumovaLebedeva.

13 Ales' Adamovich and Daniil Granin, Blokadnaia kniga (Moscow: Sovetskii pisatel', 1979), translated into English as $A$ Book of the Blockade, trans. Hilda Perham (Moscow: Raduga, 1983).

14 Lidiia Ginzburg, "Zapiski blokadnogo cheloveka," in her Chelovek za pis'mennym stolom', 1989), 517-98; idem, Pretvorenie opyta (Riga: Avots, 1991), 580; D. S. Likhachev, "Kak my ostalis' zhivy," Neva 1 (1991): 5-31. 
found in her wartime notes. Responsive and generous people are described in her memoirs, and Freidenberg never fails to mention when, where, and how they offered her help and compassion. But they all are represented as disconnected, dissociated, moving chaotically, like mechanical particles in a solution. Any interhuman space, where one "I" establishes a relation to the "I" of the other, is absent from the context of Freidenberg's memoirs of the war, and the absence changes the meaning of the facts within the entire structure. If the fundamentals of Christian anthropology define resurrection as "death denied by death," then the formulaic definition of "The Siege of a Human Being" reads "life denied by life," thus making spiritual regeneration impossible. Rather than facts and events, it is the relation of a multiplicity of facts to the existential factor of Being which is experienced by Freidenberg differently from other memoirists of her time.

For her, the function of one's life and autobiography is distorted by the structure of the myth that rejects humanness and human life as a whole. The most terrifying page of "Recollections on My Own Self" conveys the image of death gestating death-death carrying death in the womb, as if during pregnancy:

On the night of 28 March [a few days before Anna Osipovna's death, on 9 April 1944-N. P.] on the very same night when fiftyfour years ago my mother, in pangs, had delivered me to life, on this very night I witnessed again the horrible pain of delivery which my mother of eighty-four had passed through. She cried out to me and said, "Let the child out of my womb!"-Now I experienced the only anguish inaccessible to a human being. I witnessed my own birth. Oh, how horrible was this night! Life had no mercy on me, it made me pass through the only trauma which is hidden from any living being. (10: 99)

The siege led to both a physiological and a spiritual wasting away, destroying biological life and human nature. The besieged had only one hope left-to realize themselves in their second nature: in culture. Ol'ga Freidenberg was among a number of intellectuals who managed in these terrible years to fulfill themselves through scholarly creativity. In her diary she noted when and under what conditions moments of illumination would descend:

It was 25 February [1943-N. P.]. We were already in bed. Mama, with great animation, spoke about Cicero and how the mere contact with antiquity carries away, uplifts and heals her soul. Suddenly I felt a wild rage come over me.

"Don't talk to me about antiquity, about scholarship. I've asked you a hundred times. Leave me alone, don't torture me, 
don't pour poison on my wounds. My life is ruined. Scholarship has been killed in me by everyday routine and hunger. I'm in such pain. Leave me alone!"

We quarreled. I burned in a fire of bitter memories of the person I had been before.... My head burned and my heart beat and "thought-feelings," "thought-waves" ran through me. I began to think about myself and about scholarship.

My old element, closed off by silt, stirred, and I floated to the side. Like mermaids, one lucid idea after another began to emerge from deep currents of trans-conscious thought. It felt as if I were starting to give birth, as though something important, almost paramount, was issuing from me, rising from very far-off and dark areas. Here was scholarship, and here I was, and my life, and questions of fate and of everything that humanity writes with a capital letter... Suddenly the major landmarks of my existence and scholarly achievements, no matter how subjective, were revealed to me. I suddenly understood the error and inadequacy of my definition of form and content, supposedly identical. I understood the error in Marr's main thesis of morphology as semantics, which I had considered my deepest conviction. My whole theory was built on the proposition that form is the external, outward appearance of content, as I said, its molding. The contradiction between form and content arises at secondary stages, but it is not present in genesis. Here I concurred with orthodox Marxist dialecticians, I totally agreed with Marr. In all my works, beginning with the Greek novel, I studied the problem of the construction of form. I looked for conformity to this principle and "topics of variation," as I formulated it for myself. My most central interests were always directed there....

$[N]$ ow the primordial and everlasting essentiality of the inequality of semantics and its morphology had been opened up to me, bringing very profound philosophical conclusions about myself and life as a whole. Semantics had always to remain invisible in the background; being [bytie] saw as a morphology with its own new qualities-new in relation to the semantics....

The thought that form, in relation to semantics, is a new quality, not its mold (as I earlier thought), not its outward appearance (as Marr and Marxism taught, when speaking of a genetic stage), overturned my former constructions, yet opened new philosophical horizons to me. Never before, in any period whatsoever, had being served as a direct expression of that which called it into existence-otherwise there would not be that eternal, mysterious secret which comprises the essence of the 
universal process of becoming. Semantics functioned as form and in a form, but these two different elements embraced something much greater than merely being and non-being....

I began to feel great ties to life and complete indivisibility with its internal forces; I wanted to work, to return to scholarship.... And I sensed that my work awaited my philosophical generalizations and that they would come and that I was still alive and stood as in my youth, before the second serious and large stage in my scholarly life. (9: 46-49)

The second stage of Freidenberg's scholarly life consists of works written in fits and starts, in the intervals between bombardments and gun fire, in the spring, summer, and early fall, until her hands froze and her ink turned to lilac ice. These are "The Origin of the Epic Simile," written during October-December 1941 and published in extracts in 1946, and Lectures on the Theory of Ancient Folklore, whose last page bears the postscript: "Spring 1941-October 1943, besieged Leningrad." This segment of her work, as well as everything she produced during the post-war decade, from "Palliata," which examines the main thematic components and composition of the Roman comedy of disguise, to Image and Concept, was addressed to eternity, for only eternity can be conceived of as "something much greater than merely being and nonbeing." 16

15 O. Freidenberg, "Proiskhozhdenie epicheskogo sravneniia," 101-13; "Vvedenie $\mathrm{v}$ teoriiu antichnogo fol'klora," first published in Mif $i$ literatura, 9-169.

${ }^{16}$ Freidenberg's "Palliata" (1945-46), published in fragments in Mif i teatr, 3673. The genre definition of a comedy, Palliate (from Latin pallium, a cloak, a robe), bespeaks the composition of its plot and the function of plot-lines and characters. Freidenberg also traces figurative images and metaphors of disguised truth, apparent lies, impostures, and pretense. 
Part 6

Freidenberg's Last Decade: The Siege of Humanity Continues

The light

Runs from the dark, the dark from light

Towards a black and white total emptiness.

Stephen Spender, World within World 


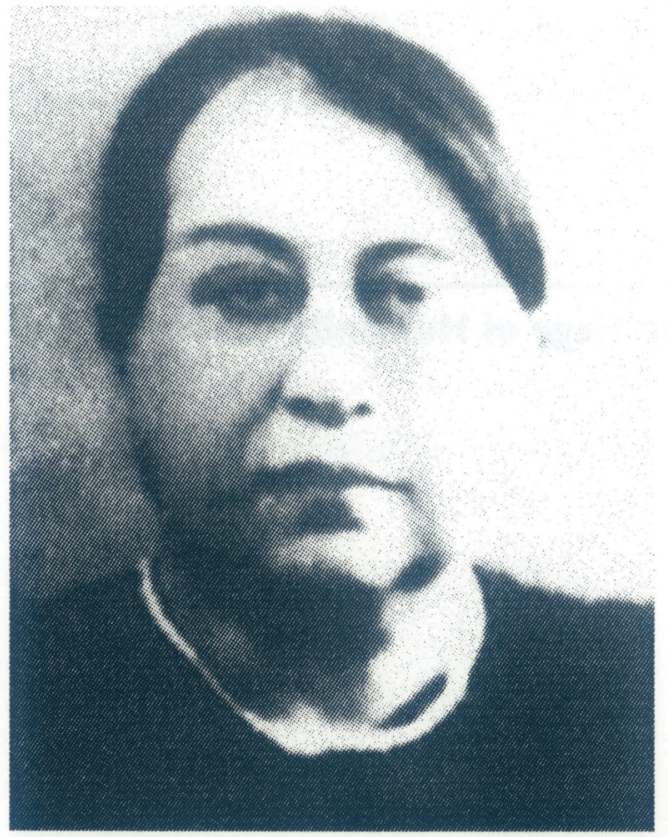

Freidenberg after World War II

Pasternak after World War II

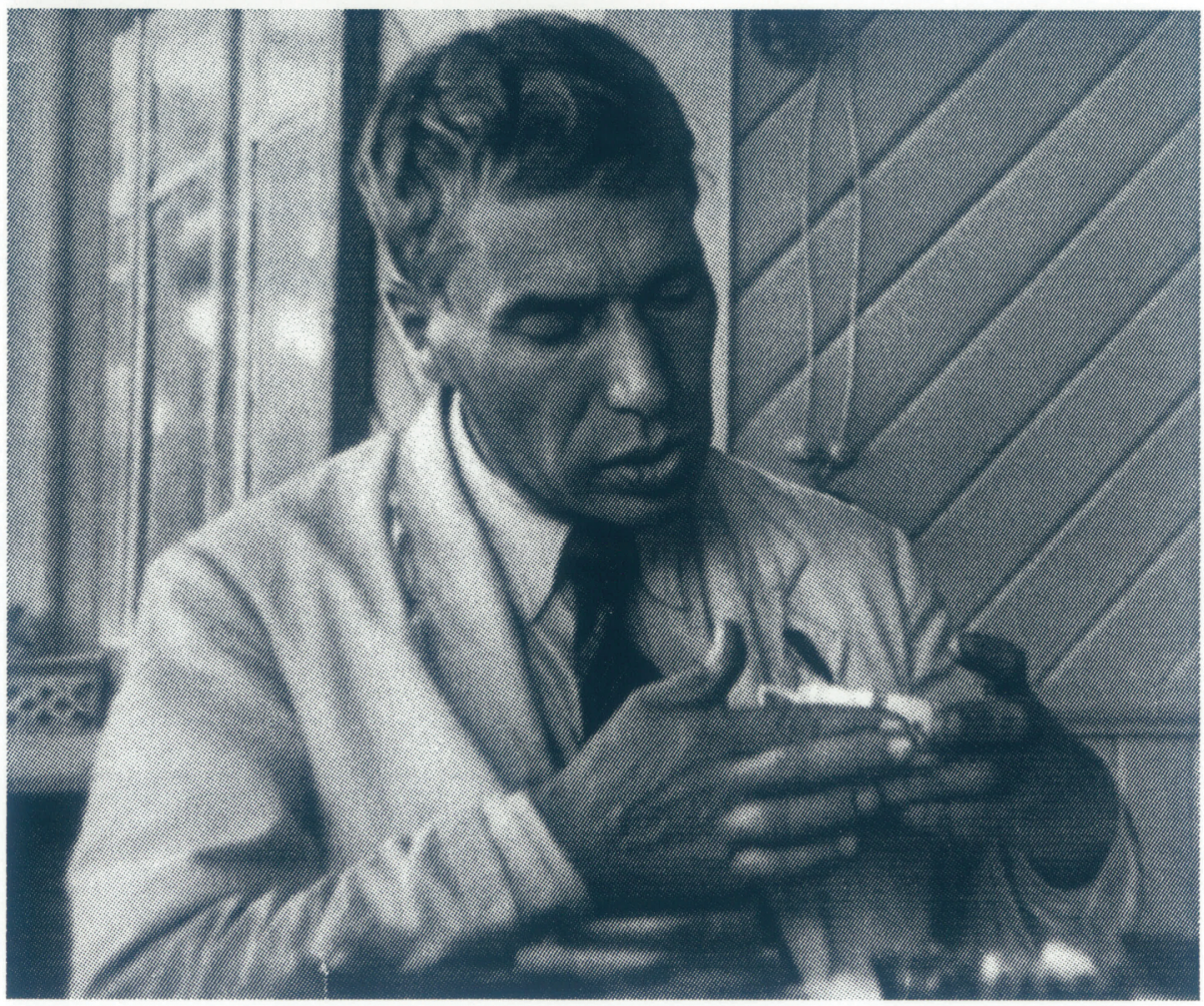


Chapter 10

Historical Aesthetics and the Socio-Historical Method in Literature

\section{A. "I Have Looked Biology in the Eye. I Have Lived under Stalin" (11: 2, 26 June 1945)}

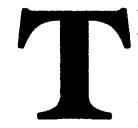

he siege of Leningrad that devoured the lives of those closest to Freidenberg's heart and killed her mother, put an end to her personal life as well. Freidenberg repeated unceasingly and in different words that reality, the world in which she lived her life and was destined to die, had lost its meaning for her. ${ }^{1}$ In this situation, the world of ideas and of culture remained the only space that still kept her within reach of "the universal brotherhood of humanity."

In great excitement Freidenberg awaited the University's return from evacuation in Saratov. She realized that only distance had muffled the old disagreements between her and her other colleagues, but she also understood that I. M. Tronskii and I. I. Tolstoi, who took upon themselves the academic and administrative supervision of the department during the evacuation, now had reason to expect her to cede the throne to them. Freidenberg, in her perfectionism, was hurt by the very idea of comparing her services to the department to anyone else's achievements, and her scruples made the use of administrative diplomacy an inadmissible stratagem in the battle for the chair. Contrary to her expectations, Tolstoi and Tronskii did not dispute the chairmanship with Freidenberg. Rather, political powers and administrative forces of a far greater

\footnotetext{
${ }^{1}$ See, for instance, Correspondence, 244, and the entry in The Race of Life, 26 June 1945: "I have lost my feelings for family and friends. My friends irk me and I rarely recall Boria. Life has become a mirage, a distant echo, a burned out fire.... I resemble the Lavretskiis and the Vronskiis when the novels about them are finished" (11: 1-2). Yet even this desperate, meditative passage, which she wrote to preface her volume 11 , begins with the name of her new study: "I am sitting and working on 'Palliata."'

${ }^{2}$ Mossman, Correspondence, 271.
} 
magnitude caused drastic changes in culture and higher education during the post-war period and made Freidenberg consider resigning her position in 1946, and then in 1948, and finally forced her to quit the job in 1950.

In her post-war diaries Freidenberg described people's unethical daily behavior and low morals: "Wherever you looked, in all our institutions, in all our homes, squabbles (skloka) were brewing. Skloka is a phenomenon born of our social order, an entirely new term and concept, not to be translated into any language of the civilized world. It is hard to define. It stands for base, trivial hostility, unconscionable spite breeding petty intrigues, the vicious pitting of one clique against another. It thrives on calumny, informing, spying, scheming, slander, the igniting of base passions.... Skloka is the alpha and omega of our politics. Skloka is our method."

As Freidenberg confesses, she herself was not immune to the pestilence of skloka. Rabidly hated by the political clique, she responded with rancor and accused her political denouncer Natal'ia Vulikh of falsifying the exams for students and providing them with "ideologically harmful bourgeois sources" for studying ancient literature (15: 119). Yet in Stalin's 1948, as in Orwell's 1984, not the thought, but "only the Thought Police mattered," and Freidenberg's information was ignored by the Rectorial Commission. ${ }^{4}$ In her diaries Freidenberg reacts to the denunciation of Anna Akhmatova and Mikhail Zoshchenko and to the banning of the two Leningrad journals on 16 August 1946. She describes "the change in political course," announced as "a shift of ideology in favor of the Great Russian people," and the onset of antisemitic propaganda.

Political smothering grew more intense. The moment arrived when Stalin's claws reached academic circles. (14:29)

Freidenberg mentions the public discrediting of Boris Eikhenbaum in 1946, during which time he lost his wife (2 December 1946), and the second squall of persecutions that followed him in April 1949 and caused his severe illness. She describes the irreparable losses to the humanities inflicted by the onset of the anti-Veselovskian anticosmopolitan campaigns and refers to the notorious speech delivered by Aleksandr Fadeev at the Institute of World Literature on 20 February 1947 (15: $16-18,65-81)^{5}$

${ }^{3}$ Ibid., xvi.

${ }^{4}$ George Orwell, 1984 (New York: Signet, 1949), 6.

${ }^{5}$ In his speech "The Tasks of Literary Criticism" ("Zadachi literaturnoi kritiki"), Fadeev labeled Veselovskii the "progenitor of an entire literary schoolthe school of vagabonds worthless for mankind." See his Sobranie sochinenii 
If on 6 November 1936, an extraordinary session of the Department of Ancient History condemned Freidenberg's Poetics of Plot and Genre in her absence from the meeting, then now, on 1 June 1948 she was summoned to her "public discreditation." "The Party leaders," writes Freidenberg, "reserved the entire afternoon for this session, so that in the evening they would be free. In the evening they scheduled another meeting, in honor of the great Russian humanist Belinskii, during which, feigning morality, they celebrated the triumph of free-thinking." (14: 70).

Each change of political course brought more and more destruction to Freidenberg's department. Her younger colleague Sof'ia Poliakova was charged with "eroticism" in her academic interests (11:2: 47); her student Aleksandr Zaitsev was arrested (12:2: 19-23); two graduate students, Ol'ga Gutan and Berta Galerkina, were deprived of their Ph. D. diplomas (11:3: 41-47, 56-64; 12:1: 1-6; 27-30; 12:2: 28-34; 15: 71-78), and the anniversary collection of the scholarly works of the Classical Department was broken up because of "obsequiousness toward the West." (13: 16)

Now that numerous documentary sources of the period are available in Russia, we can compare Freidenberg's memoirs to Boris Eikhenbaum's "Diary, 1946," to Lidiia Ginzburg's documentary prose, to a historical survey "On Obsequiousness and Cosmopolitanism" by Konstantin Azadovsky and Boris Egorov, and to other texts. ${ }^{6}$ Now we know that many Soviet intellectuals were flabbergasted and thunderstruck by the overt cynicism of the political campaigns of the mid-forties and fifties. But we should not forget that in their astonishment and pain, almost none of the survivors and victims dared to share their feelings with anybody else. Like Dostoevskii's Underground Man, each person silently thought: "I'm alone, and they are everyone."

Horrified as she was, Freidenberg, an old woman, her heart dry and empty, her whole "life uprooted," had enough moral fortitude to go on writing, teaching students and fostering younger scholars for five more long years. (11:1: 1) For the first post-war anniversary session of the University, she presented her paper "On the Origin of Greek Simile" (written in October-December 1941, in Leningrad). In 1945 she submit-

(Moscow: Gosudarstvennoe izdatel'stvo khudozhestvennoi literatury, 1960), 4: 403-42.

${ }^{6}$ B. M. Eikhenbaum, "Dnevnik 1946 goda," Peterburgskii zhurnal 1-2 (1993): 183-202. Part 1 of the issue, "Zhurnal Leningrad. Avtobiografiia" (7-65), recounts the history of the edition which was banned following Stalin's decree: "Leningrad [the city- N. P.] will survive without Leningrad [the journal-N. P.]." See also K. Azadovskii and B. Egorov, "O nizkopoklonstve i kosmopolitizme," Zvezda 6 (1989): 157-76. 
ted to the editor of the University Proceedings, Professor Sergei Dmitrievich Balukhatyi, a manuscript of her article "On the Origin of Greek Metrics," and Balukhatyi, then already gravely ill, accepted it with great appreciation. "Ol'ga Mikhailovna," he said, "is the most inventive person" (11: 2: 19), and arranged for her work to be allotted double the usual number of pages. ${ }^{7}$ In a situation when "moral and intellectual pogroms spread like a plague through the cities of Russia," when knowledge of European sources was labeled as "obsequiousness toward the West," and "groups of students rummaged through the works of Jewish professors, eavesdropped on their private conversations, and whispered in the corners," Freidenberg dared to keep people of Jewish origin in her department and began to work on Sappho (12:1: 56-57). "I did not accept the common conception of Sappho.... The Lesbian theory seemed to me the height of vulgarity. Sexual excesses could not find realistic expression in the classical genre, which drew its themes from inner, rather than outer sources." 8

In 1946-47, Freidenberg still somehow managed to present for public discussion two small excerpts from her 238-page manuscript on Sappho. Her Sappho abstract appeared when the Department of Classical Philology was in "complete disarray," and members of the faculty and her editors were harassing her. In order to have her piece published, she had to make certain concessions. A comparison of her manuscripts with the published excerpt speaks for itself and for the historical reality of the late 1940s. In her memoirs Freidenberg wrote:

The masculine element is found in Sappho's songs, and it is expressed in typically matriarchal forms that make it difficult for modern researchers to recognize it. Sappho's songs cannot be dated precisely. But one thing is certain: Sappho, like Homer, belongs to folk art. The direct implication of the breakdown of genres is a breakdown of the social consciousness. The changed social outlook, in which the main role is played not by gods and nature but by man and society, created the lyric. Sappho's lyrics are on the border between thinking in images and thinking in concepts. The mythical image of the world is edged out by a realistic, social picture. ${ }^{9}$

And in an unpublished chapter from the monograph Freidenberg provided an exhaustive explanation for what she termed "the masculine element in Sappho's songs" and what was absolutely inadmissible to the

${ }^{7}$ Freidenberg, "K voprosu o proiskhozhdenii grecheskoi metriki," Uchenye zapiski LGU. Seriia filologicheskikh nauk, no. 90, vyp. 13 (1948): 290-332.

${ }^{8}$ Mossman, Correspondence, 294.

${ }^{9}$ Cited in Mossman, Correspondence, 294. 
sterile and chaste outlooks of her editors. ${ }^{10}$ Freidenberg analyzed Sappho's invocation to Aphrodite (book 1, fragment 1, "Ornate-throned Immortal Aphrodite"). ${ }^{11}$ The female poet begs Aphrodite to descend from heaven to earth (as the mighty goddess used to do before) and help her win the love of a person who does not love her. In this dialogical poem, Sappho, the actual speaking subject, moves into the background, and Aphrodite, the object of the female poet's invocation, steps forward, addressing the author of the song. The divine protectress of the female author acts as Sappho's champion, symmachos, who fights on behalf of her and in her stead. The goddess Aphrodite is Sappho's symmachos, while the poetess is seen as the earthly female hypostasis of the divinity of love. Sappho's only function is to seek love, and Aphrodite's only function is to satiate Sappho's passion; however, no one reciprocates the feelings of the poetess. Like Apollo, the god of beauty and music, who knows no reciprocity in love, Sappho, the poet-creator of her love songs, is unloved and unmarried. As Freidenberg observes, both Apollo and Sappho lack spouses and are, as it were, "sexless." Sappho's life, as it is shown in her poems, is but an invariant of the myth of Apollo, and both represent vestiges of archaic muse-related (musicheskie) images which were not yet distinguished by gender. Like Apollo, accompanied by a choir of Muses, yet not connected by bonds of love with any of them, Sappho is shown amidst loving beautiful women who are not her lovers. Male poets worship Apollo, pay adoration to him and glorify the handsome victors of athletic games, and Sappho pays adoration to Aphrodite and worships beautiful women, the temple priestesses and participants in competitions of female song-makers.

The fragment from Freidenberg's manuscript demonstrated that survivals of folk epic tradition and choral songs, rather than a proclivity towards male or female sex, constituted the body of Sappho's lyric (13: 2: 77). However, in the introductory passage to her publication on Sappho, Freidenberg forced herself to submit the following:

In bourgeois science, Sappho has been approached either from an antiquated or from a formalist position. She has been treated as but another bourgeois "poetess," as an "author" of contemporary European "love lyrics." The specific characteristics of the epoch by which Sappho ought to be defined, the social condi-

${ }^{10}$ O. Freidenberg, "Fr[agment] I, Safo," ed. N. Braginskaia, Novyi krug 2 (1992): 142-48. In 1948, Freidenberg's old colleague Tronskii, one of the editors of the university Proceedings, refused to publish her paper "Sappho's Second Fragment," frightened by "its erotic material" (14: 16).

${ }^{11}$ Freidenberg uses the Greek original and Viacheslav Ivanov's Russian translation; I use Greek Lyric, trans. David A. Campbell (Cambridge and London: Harvard University Press, William Heinemann, 1982) , 1: 52-55. 
tions that determined women's life in ancient times, as well as the limited ideological consciousness of a slave-owning society were not taken into consideration.... Bourgeois scholars vulgarized the "lesbian" theme and distorted it by analogy with the morality of a modern capitalist city. ${ }^{12}$

Freidenberg's abstract could only partially convey her original concepts, and forwarding an offprint to Boris Pasternak, she lamented: "I am sending you the sediment rather than the wine. Even so, the epigraph ought to read, 'Life is everywhere.' This, at least, has pushed its way through to the light of day. In the original the stress is on textual analysis." The invisible epigraph "Life is everywhere" referred to the popular painting Vsiudu zhizn' by Nikolai Iaroshenko (1846-98), who depicted prisoners headed for exile in Siberia, looking out through ironbarred windows onto the landscape. "Sappho" was the last article Freidenberg was allowed to publish during her lifetime.

\section{B. Ol'ga Freidenberg and Grigorii Gukovskii on Historical Poetics: The Collective Societal or the Socio-Historical Interpretation?}

Considering Freidenberg's treatment of the origin of literary plots and genres, the epistemological distinctions between her "historical aesthetics" and the dominant, socio-historical interpretations of literature, culture, and ideology take on increased importance. From the late 1920 s through the late 1940s, Grigorii Gukovskii (1902-50) was the most talented Soviet social critic and an acknowledged authority in the area of literary sociology. At first glance, it appears that Gukovskii and Freidenberg shared many common views as theorists. For different theoretical and methodological reasons both supported the principal postulates of cultural and historical development by stages. Gukovskii and Freidenberg both discussed functional changes within and beyond the limits of genre, and thus they treated historical poetics in connection with the development of collective consciousness (Freidenberg on folklore) or the evolution of social and ideological values (Gukovskii on literature).

An unbiased treatment of the Freidenberg-Gukovskii dichotomy should begin by acknowledging the extensive shared aspects of their aesthetics. As theorists, both offered views on the methods which they then applied as an epistemology to literature, literary studies, and the history of culture. Supporters of the "stage theory," they believed that

12 O. Freidenberg, "Safo," Doklady i soobshcheniia filologicheskogo instituta LGU 1 (1949): 190.

${ }^{13}$ Mossman, Correspondence, 296. 
this creed offered an interpretation of cyclical development. The acceptance of cultural cycles enabled them to treat different stages in the development of poetic awareness as manifestations of autochthonous (independent and self-generating) processes. In order to justify the autochthony of artistic development, both relied on semantics. Freidenberg's thesis was that in ancient Greek literature individual works (as well as the biographies of their creators, the individual poets) could be preserved by cultural memory only if they reflected upon the collectively acknowledged picture of the universe with its system of values. This corresponded to Gukovskii's statement that a historical milieu "forms the basis of the aesthetic reality of the work, and is itself, in turn, created on the basis of common assumptions of the aesthetic thinking of the era as a higher unity." 14

Freidenberg repeatedly emphasized that the development and context of ancient Greek literature did not yet constitute "Classicism," while Gukovskii unceasingly argued that the European and Russian literatures of the seventeenth-eighteenth centuries were no longer what the Classicism of Greek antiquity used to be. He insistently used the term "Pseudo-Classicism" for his discussions of seventeenth- and eighteenth-century poetic phenomena. The acceptance of the "not yet/no longer" opposition localizing cultural phenomena in time and history seems to characterize both Freidenberg and Gukovskii as supporters of cultural cycles; yet, paradoxically, the very core of the scholars' controversy originates in their different interpretations of the "not yet/no longer" correlation.

The works which Freidenberg wrote from 1939 to the late 1940 s deal with cultural history as the validation of the human self in empirical reality. This topic, first introduced into her scholarship by the paper "On the Basic Characteristics of Greek Literature," delivered in 1939 at the Jubilee meeting dedicated to the 120th anniversary of Leningrad University, was later complemented by a series of fragments on the origin of the Greek lyric. ${ }^{15}$ Freidenberg insisted that Greek literature of early antiquity differs from all other literatures of later cultural epochs in the sense that "it reveals the coming into being of new genres and of

\footnotetext{
14 G. A. Gukovskii, "Toward the Problem of Russian Classicism: Competitions and Translations," Soviet Studies in Literature 21: 1-2 (1984-85): 47. First published as "K voprosu o russkom klassitsizme: Sostiazaniia i perevody," Poetika 4 (1928): 126-48.

15 O. Freidenberg, "Ob osnovnom kharaktere grecheskoi literatury," Uchenye zapiski LGU. Seriia filologicheskikh nauk, no. 60, vyp. 6 (1940), 32-50; "Safo," 190-98; "Proiskhozhdenie grecheskoi liriki," 103-21; "Fr<agment> I, Safo," 14348. All fragments were written as chapters for her monograph on Sappho.
} 
the literary process as a whole." ${ }^{16}$ Insofar as early Greek literature was experienced as something qualitatively different from folklore, individual poets, the oldest of whom was Pindar, made efforts to separate themselves and the subjects of their songs from the communal tribal traditions of oral lore. ${ }^{17}$ Early Greek literature had its own specific subjects of depiction and comprehension, yet the occasions and circumstances of individual performance-the very presentation of the ancient ode, the song maker's invocation of the Immortals, the verbal forms as well as poetic allusions that permeated the plot of the song-maker's presentation and his self-adjuration-addressed collective consciousness. Within the limits of early Greek culture, the poet's self-adjuration, that is, the discourse which the song-maker addressed to himself, bore no meta-poetic connotations. Rather than divesting communal values of their meaning, the poet invested the individuals he glorified and their personal objectives (to win the city from the hands of the enemy, to win a competition in sports) with the value of superhuman, heroic deeds. The poet depicted the success of his victors through a system of mythological images whose validity still remained collectively acknowledged. Thus Pindar, the bard of the state's aristocracy, who "swept aside the traditions of the populace," eulogized individual rulers, tyrants and kings, yet he glorified them as the winners of pan-Hellenic competitions in the Olympian, Nemean, and Pythian games. The individual victors were members of aristocratic families, but the games-occasions of universal veneration-were arranged on collectively established sacred days and were held in holy places. Pindar's epinician songs glorified the individual achievements of the victors, but the victors' lives and the stories of their families were compared to the histories of Immortals-divine heroes and Olympic gods. The transient facts of earthly life found their place in the eternal chain of being and were treated as momentous events that pertained to immortality. Pindar depicted the extraordinarily high skills of the contestants as hard "works" comparable to the righteous deeds of the legendary heroes-those taken to heaven by the immortal gods. In Pindar's odes, mortal life became part of eschatology through images of divine righteousness, everlasting spring, plenty, and wealth. Both the ode as a new literary genre and early Greek literature as a whole represented a stage in the cognitive process whereby the myths of the divine rulers (gods) were used to glorify the lives of the

\footnotetext{
16 "Ob osnovnom kharaktere grecheskoi liriki," 32.

${ }^{17}$ Freidenberg has in mind the well-known fact that the winners in the Olympic games, their wealthy patrons, or members of the family commissioned the poet to write the commemorative ode. Thus, the subject of the event, the central figure of the ode, and the epinician style of the poet represented the ideas of the aristocratic elite and the nobility.
} 
ideal kings of the Grecian people and to bring about a new understanding of the individual's "self." The latter transformation involved the object of the poet's encomia - the figure of the victor as well as the poet's image of his own "I." Chosen to valorize mighty deeds, the poet too was viewed as a victor whose songs commemorating the success of almost legendary heroes remain forever alive in the people's memory. However, Freidenberg insisted, in Pindaric odes, neither the victor, the actual subject matter of the song, nor the song-maker were yet envisioned in categories comparable to those of the contemporary "hero" and "author."

In her study of the origin of the Greek lyric, Freidenberg emphasized that people create a different picture of the world at different historical stages of development. What is most decisive is the interrelationship of the world as an object of knowledge and the human consciousness that comprehends it. Since in the earliest period, man does not separate himself from the surrounding nature, subject and object are merged in his consciousness.

Greek society is so archaic that the development of concepts is still occurring within it. However, it is so young that this process has already begun and is even moving significantly forward... We must take into consideration the fact that cognitive processes become shaped as fixed ideologies with great delay, so that their original models do not coincide with the finalized forms [that these ideologies take on-N. P.] The separation of subject from object does not occur in a linear way. The process in which the subject and object take on each other's functions continues for a long time.

Греческое общество настолько архаично, что в нем происходит становление понятий. Однако он настолько молодо, что в нем этот процесс уже начинается и даже значительно идет вперед.... Необходимо, однако, учесть, что познавательные процессы отлагаются в виде сложившихся идеологий с большим опозданием и хронологически не совпадают их готовые формы и истоки. Отделение субъекта от объекта не идет линейным путем. Очень долго продолжается процесс, при котором субъект и объект выступают в функциях друг друга. ${ }^{18}$

The most striking example of this gradual separation of the knowing subject from the object, Freidenberg stated, "is the birth of the author" in the Greek lyric.

${ }^{18}$ Freidenberg, "Proiskhozhdenie grecheskoi liriki," 106. 
Like Pindar with his monodic, rather than choral odes, the lyrical author is still very much a rhapsodist, who continues the musical tradition (musicheskaia traditsiia) of song-making. This lyrical author does not conceive of his own self as an individual personality, but views his "I" as a form of deity or oracle, aware of being in communication with the gods. The lyrical author still represents deified nature, though no longer in images-rather through concepts that are just in the process of being born. Lyric poetry represents a great change in social consciousness, yet the link to mythic awareness remains clearly palpable in the self-consciousness of the song-makers, in the thematics and allocation of their songs, as well as in the invocations of their divine protectors who are beseeched to endow the poets' songs with special meaning and to extend to the poets their divine powers. "What used to be cult in religion, in the musical tradition, is now the poet's life, the objectified world.... The feasts where lyric song-makers perform, the religious processions and festivals, the character of competitive performances, special garments, wreaths, special poetic appurtenances, and the singers' attributes-flowers, adornments, special shoes, the lyre"-all these paraphernalia characterize the "lyric scenario" as "a conceptual variant of a cult," yet at the same time they all work to separate the objective and the subjective plane of perception, thus introducing the poet's individual point of view. ${ }^{19}$ The lyric song-maker is now an individual subject who sings "about" his object; he experiences certain states and relates them in his song, and this is how a new category of lyrical narrative comes into being. Unlike the epic bard, the lyrical poet not only enumerates, but classifies as well, and by translating the objective to the subjective sphere he renders personification as metaphor. "The Greek lyric," concludes Freidenberg, "is valuable because its genesis shows the origin of poetry. Moving from Sappho to Pindar, the classicist recognizes the way that poetic metaphor comes into being; and, following the process of metaphorization, he recognizes how the new cognitive system that we call lyric comes into being."20 Freidenberg's historical aesthetics explained the recognition of a specifically poetic communal consciousness in culture and in the world views of individual authors.

In the 1940 s, while tracing this process through the history of Greek literature, Freidenberg undertook a substantial revision of her own paleontological ideas, emerging with a more specific conclusion, according to which vestiges of mythological semantics were treated as figurative images-the "crossroads of old and new." The archaic substratum underlay the morphogenesis of new poetic images and concepts, but the specific morphology of new genres was no longer tied to the primordial

\footnotetext{
19 Ibid., 108.

20 Ibid., 116.
} 
antinomic unity. On the contrary, as Freidenberg demonstrated in her articles on Sappho and on the origin of the Greek lyric, breaking apart the bivalent identity was an epistemological upheaval, a transformation which brought about the split between the knowing subject and the object of his cognitive activities-the universe and nature that the poet was coming to know and describe through concepts which were still in the process of formation. The fundamental factor in the genesis of the Greek lyric, by which the real historical world was assimilated in categories "of concepts arising directly from the image," brought about a radical change of social consciousness. It is therefore no coincidence that in the history of culture, "the lyric and philosophy arise almost simultaneously as two basic conceptual categories." 21

In the 1940s, the neo-Kantian connection in Freidenberg's historical aesthetics could no longer be overtly expressed, but those familiar with The Philosophy of Symbolic Forms would recognize in her treatment of the specific qualities of Greek literature Cassirer's formulae: "not nature but society is a true model of myth: all of its fundamental motives are projections of man's social life" and "the principles by which the manifold of experience receives its structure are not static but dynamic."22 Like Cassirer of the 1940s, but independently from him, Freidenberg had now arrived at the conclusion that although by the seventh century B.C. the cognitive consciousness of Greek society was determined by peoples' class position and organized into different ideological views (politics, philosophy, poetry, ethics), the multitude of societal cultural manifestations were not yet arranged into a hierarchy of values. ${ }^{23}$ Therefore the "birth of concepts arising directly from images" was enacted differently by the lyric and philosophy, by drama and ethics, and by tragedy and mystery-cults.

Recognition of the communal poetic consciousness in culture and in the worldviews of individual authors characterizes Freidenberg's epistemological position as entirely different from Gukovskii's dialectics, which has its roots in Hegelian aesthetics and Marxist sociology. Gukovskii's adherence to Hegelian dialectics enabled him to combine the notion of cultural cycles with those of evolution and historical progress. The Hegelian thesis-antithesis-synthesis triad and its pragmatic consequence, the Marxist interpretation of the spiral path of historical development and cultural evolution, were cornerstones of

\footnotetext{
21 Ibid., 122.

22 Cassirer, An Essay on Man, 79.

23 Ernst Cassirer, "Logos, Dike, Kosmos in der Entwicklung der griechischen Philosophie," Göteborgs Högskolas Arskrift 47 (1941): 3-31; see also An Essay on Man, 75-78. Cassirer's studies written during the mid-1930s-1940s were not available to Soviet scholars.
} 
Gukovskii's aesthetic edifice and provided the grounds for his interpretation of how stage/structure correlations operate in European cultures. According to Gukovskii, only in connection with Marxist dialectics could the stage theory explain a progression from the system of general universals (Classicism) to that of the inimitably individual poetic features (Romanticism), and from there to the individualized manifestations of universal properties (Realism).

Like Freidenberg, Gukovskii traced the relations between the knowing subject and the object of his cognitive activities: the social world, nature, and the individual psychologies that the poet was coming to know and describe in his works. Gukovskii relied heavily on the stage/structure correlation in his explanations of how an individual author "can assimilate the achievements of more than one social class or historical period and can view them ... as models with some analogous relationship to his own life." ${ }^{24}$ The choice of assimilable artifacts was determined by the poet's ideology, which was in turn historically bound, occupying the highest position within the system of cognitive social values. According to Gukovskii, whose focus was on Russian and European culture of the seventeenth and eighteenth centuries, literature has always been an integral part of the social fabric, and as an institution has always been bound to class ideology. Great writers and poets always "translated" one ideologically-charged speech genre into another; yet as individual authors they all were different, for each had an individual sense of ideological authority and aesthetic value comparable to or incompatible with his own time and culture.

As two outstanding philologists who began their careers at Leningrad University at almost the same time (Gukovskii was hired a few months later than Freidenberg and continued to work at the Department of Philology until his arrest in 1949), Freidenberg and Gukovskii could not have remained uninformed about the epistemological differences and striking similarities of the themes, subjects, and applied methods of their works. To their credit, they never overtly expressed reservations about each others' philosophical positions, although their professional relations were always strained. ${ }^{25}$

\footnotetext{
${ }^{24}$ I borrow this definition of Grigorii Gukovskii's social criticism from William Mills Todd III, Fiction and Society in the Age of Pushkin: Ideology, Institutions, and Narrative (Cambridge: Harvard University Press, 1986), 112. I find Todd's chapter "Institutions of Literature" (45-105) of particular significance for an understanding of the sociology of culture.

${ }^{25}$ In her diaries Freidenberg depicted Gukovskii as a money-craving political conformist. This assessment must be treated cautiously, since her views contradict several persuasive memoirs and studies written by Gukovskii's friends and colleagues. See, for instance, N. G. Gukovskaia, "Otets," Avrora 9 (1974): 34-42;
} 
The difference in their subsequent treatments of the same theoretical subjects can best be seen by comparing Freidenberg's "On the Basic Characteristics of Greek Literature" and Gukovskii's "Towards the Problem of Russian Classicism: Competitions and Translations." ${ }^{26}$ These articles discuss victory and competition as important themes in the poetics of ancient Greek (Freidenberg) and eighteenth-century Russian literatures (Gukovskii). According to Freidenberg, in Pindar, for the first time in the history of literature, myths of immortality entered poetic discourse as abstract concepts. Yet figurative meanings were still rendered through images of God-like splendor and heroic deeds, which the poet had before his eyes when he described the combats and competitions of the mortals. The individual thematic plane, the actual subject matter, and the poetic plot of Pindar's odes were expressed through the fixed mythological, communal images of the agon (competitive combat, single battle).

One of the basic characteristics of ancient literature, Freidenberg believed, could be seen in the poetics of the Pindaric odes, in which the connection with mythological archetypal plots was not yet effaced. The mythological metaphor and the archetypal plot of the agon left their imprint on all the different planes of this new poetic phenomenon. Its heroes were "agonists" contending for and winning a prize. The agon, as a poetic formula developed through songs about the moral virtues of the local god-like heroes and their ancestry, brought about the new individual, yet collectively accepted, poetic genre of the Pindaric epinicon. Moreover, the poet who glorified the contest felt, in a way, as though he were the victor's champion. The "I" of the poet and the winner in the competition-the actual object of the victory song-merged. The personality of the song-maker, his discourse, and his feelings dissolved in the hero's history, and the entire collective which witnessed the contest shared the poet's exaltation: "I will be small among small things, great among great" (Pythia 3: 107); "In the poet's tongue might breathe the prayer that is on the lips of all" (Pythia 3:1). Pindar's "poetic objects"the athletes whose victories provided plots for his odes-also signified victories of the poet as a song-maker and immortalized his name "in words and stone." Particular biographical facts were accepted as a component of poetic plots and literary genres, and through literature,

M. A. Shneerson, "On chelovekom byl. Pamiati professora Gukovskogo," Grani 122 (1981): 135-54; I. Z. Serman, "G. A. Gukovskii," Soviet Studies in Literature 21, nos. 1-2 (1984-85): v-xxv; and L. Ia. Ginzburg, "I zaodno s pravoporiadkom," Tret'i Tynianovskiie chteniia (Riga: Zinatne, 1988), 218-31, where pp. 218-21 discuss the poignant problem of an intellectual trying to live in agreement with Stalin's order.

${ }^{26}$ Gukovskii, "Russian Classicism," 46-75. 
remained immortal in the memory of mankind. With ancient Greek literature, the concrete, individual event found its way into culture.

Freidenberg insistently emphasized that at different historical stages of development, people create their vision of the universe differently. The cardinal thing to be taken into account is the correlation between the known world and the knowing human consciousness. Figurative descriptions of concepts as abstract as, for instance, the predestined ordering of events associated with the decisions of the Fates in archaic eschatological folklore are not to be met in any other "classical" literature. Modernized ideological interpretations of cosmology, ancient religious beliefs, and eschatology ignore the autochtonal origin and organic unity of ancient literature and make impossible to understand the traditional images that conveyed the notion of "the vast scope of the Fates' designs, or the irrevocable nature of their decrees and their formidable and final character."27

Freidenberg believed that the genesis of poetic phenomena cannot be explained through the ideological superstructures which occupy the highest hierarchical level in the causally determined system of social consciousness. Here she disagreed with Gukovskii, who posited the paradigmatic power of ideological structures over culture in his treatment of literary evolution. For him, the "institutionalizing" of various artifacts accumulated in the humanities was as important as the analysis of constituent "structures of separate facts and literary works." ${ }^{28}$ Even in his works written for the Formalists' Poetics, Gukovskii insisted that the classification of objects according to the principle of contiguity (po printsipu smezhnosti) must be subordinated to their grouping and uniting under concepts such as "schools, movements, or traditions." The entire field of literature of any era will then constitute a segment of an even wider cultural system, and the development of literary facts will be impelled by extra-literary, ideologically, and socially bound factors. ${ }^{29}$

Gukovskii's theory enabled him to localize the art-object within a rigid, hierarchically organized system and to consider individual works as well as groups of varied phenomena to be characteristic manifestations of this hierarchy and its composition. In order to define clearly the most salient features of eighteenth-century Russian neoclassicism,

\footnotetext{
${ }^{27}$ Freidenberg, "Ob osnovnom kharaktere grecheskoi literatury," 40-50. Chaps. 4-6 of this paper dovetail with the ideas developed by C. M. Bowra in Greek Lyric Poetry from Alcman to Simonides (Oxford: Clarendon Press, 1961), from which the quotation on "the Fates' designs" is borrowed (406). Freidenberg was familiar with the first edition of Bowra's book and valued this study greatly.

${ }^{28}$ Gukovskii, "Russian Classicism," 46.

29 Ibid., 46-47.
} 
Gukovskii chose "the unusual attachment that the era of Lomonosov, Sumarokov, and Kheraskov had to poetry competitions." 30

Russian poetry of the mid-eighteenth century, Gukovskii argued, was characterized by an interest in poetry competitions and the way in which they were "staged." Competitions that proceeded from theoretical arguments in poetics were explicitly considered a battle between opposing ideas, rather than between authors. A work of art became tied to a specific question of an ideological and goal-oriented order; the best contestant and winner was the poet who most convincingly demonstrated the way in which a particular phenomenon belonged to the whole. "This idea of a single and achievable absolute solution to an aesthetic problem hangs over the entire debate, and in the theoretical debates the idea of an absolute solution to the problem of prescriptive poetics corresponds to it." 31 To put it simply, the path to aesthetic perfection was paved by an ideologically bound system of guidelines, and "anyone who took a different route was, at best, an ignoramus, a blind man. There could be no thought of respecting some other personal aesthetic world." 32 Within the framework of neoclassicism, all occurrences and aesthetic phenomena were subordinated to the power of the Great Cause and functioned to provide the most effective manifestation of the Cause.

Gukovskii's conclusion regarding the aesthetic manifestation of the dominant idea of the era was further developed into his theory of poetic styles. According to this model, "in classicism, the abstract General absorbed the concrete particular Individual. The general denied the individual and tried to eliminate it. In romanticism, the concrete individual tried to absorb the general both as an abstraction and a particular. In nineteenth-century critical realism, the concrete manifestation of the general subordinated to its power a concrete individual, yet rather than absorbing the individual, it explained and determined the individual's reality as a particular being." ${ }^{3}$ Thus, in sublation, nineteenth-century critical realism embraced and justified both general universals of classicism and individual manifestations of romanticism.

As one can see, the more effectively Gukovskii's "socio-historical aesthetics" corroborated the validity of Freidenberg's statement that "over the course of history, the same thing takes on different forms,

${ }^{30}$ Ibid., 48.

${ }^{31}$ Gukovskii, "Russian Classicism," 57.

32 Gukovskii, "O russkom klassitsizme," Poetika 5 (1929): 52.

${ }^{33}$ G. A. Gukovskii, Pushkin i problemy realisticheskogo stilia (Moscow: Gosudarstvennoe izdatel'stvo khudozhestvennoi literatury, 1957), 15. The book was written in 1948 and published posthumously after the author's name was officially rehabilitated. 
subjected, as it is, to different interpretations," the greater her reservations were about his interpretation of stage/structure correlations in cultural history. ${ }^{34}$ According to Gukovskii, in the neoclassical system, the authority of the object, of the Great Cause, dictated to the poets their objectives and their aesthetic techniques. As a pertinent feature of this system, the stage/structure correlation reoccurs and reconstitutes itself through cultural history. In this sense, Russian neoclassicism of the eighteenth century provides a model analogous to the modern pseudoclassical style of the Soviet era. In his theory of the evolution of poetic styles, allusions to the contemporary state of affairs in the humanities in the Soviet Union were quite explicit. Gukovskii offered a universal interpretative model that posited the supremacy of the universal Object and conscious objectives over the individual subject and his subjective vision of the world. Proceeding from this premise, Gukovskii posited the semantic identity of poetic tournaments and industrial production competitions and depicted the individual poet as a figure akin to a skillful production worker.

By the mid-forties, the disparity between Freidenberg's and Gukovskii's views grew even greater, for both embarked on the discussion of poetic modes, literary genres, and movements: Freidenberg, by providing interpretations to "the birth of the author," "the origin of the Greek lyric," narrative, and drama; and Gukovskii, by tracing "the ideological and stylistic transformation of romantic historicism into the more capacious stylistic system of realism." ${ }^{35}$ The highest aesthetic achievement of the great Russian realists, Gukovskii insisted, was in their ability to comprehend the degree to which individual characters were determined by milieu. "Toward the Question of the Image of the Narrator in Gogol's Mirgorod," Gukovskii's last work published before his arrest, illustrated this dialectical statement. ${ }^{36}$ Gukovskii discussed "the birth of the author," whose individual style gives expression to a system of collectively shared values and to the speech awareness of "a people" (narod). In this study of Gogol's narrative style, the antithetical opposition "collective and general (thesis)/individual and specific (antithesis)" is dialectically reconciled, thereby demonstrating the full completion of the cultural cycle. According to Gukovskii, in Gogol's Mirgorod, the author as the creator of the individual work (the cognizant and cognitive subjectum) can no longer be distinguished from the communal world he depicts.

${ }^{34}$ Freidenberg, Poetika siuzheta, 13-14.

35 I. Z. Serman, "G. A. Gukovskii," xvi.

${ }^{36}$ Gukovskii, "K voprosu ob obraze povestvovatelia v Mirgorode Gogolia," Uchenye zapiski LGU. Seriia filologicheskikh nauk, no. 90, vyp. 13 (1948): 10130. 
The principal difference between the functions of the "not yet/no longer" formula in Freidenberg and Gukovskii is now self-evident. Freidenberg's method leads from paleontological semantics to morphogenesis of poetic forms. Her morphogenesis of poetic forms (tropes, plots, and genres) explains how the separation of the knowing consciousness from the known universe brings about the "I" motif of the poet, and how this new cognitive essence of the figurative image assists in recognizing new aspects of the social world, by being expressed through individual, yet collectively accepted genres: drama, lyrical poetry, and prose narrative.

As Freidenberg argued in her Poetics, changes of morphologic structures of metaphors underlie the development of synchronic and diachronic phenomena in culture. Semantics and morphology, thus, accumulate, preserve, and modify collective memory. People acquire new categories of consciousness and a broader knowledge of the world in two ways: through the perceptual-conceptual transformations that affect and change the old structures from within, and through the incorporation of a new historical reality into a cultural context previously unknown to the consciousness of an ethnic or social group. ${ }^{37}$

\section{Freidenberg in the Late 1940s: "This is the Letter to the World that Never Wrote to Me"}

In the 1920s and 1930s Freidenberg demonstrated that literary works and the worldviews of the great ancient authors took their origin in archaic folklore, and she concentrated on a thorough study of these primeval cultures. In the 1940 s and 1950 s she projected the specific features of individual poetic genres against the general background of folklore poetics in order to describe the genesis of metaphors in different discourse manifestations. In the course of her career, which spanned the period 1924-54, her central term, "genesis," changed its semantics from "origin" to "birth of": from "The Origin of Parody" to "the birth of

${ }^{37}$ Freidenberg's formula of perceptual-conceptual transformations suggests a link to Eugenio Coseriu's functions and structures of language. Coseriu localizes creation of metaphors within communicative activities and demonstrates "how multifariously does the human imagination, always in search of new expressive images, transform meanings in order to name what the intuition had recognized and distinguished. The imagination reintroduces new relations to the obsolete or dying signs of the language so that speech contacts are always reinvigorated in order to convey the novelty of the new intuition." See Eugenio Coseriu, Sprache: Strukturen und Funktionen (Tübingen: Verlag Tübinger Beiträge zur Linguistik, 1970), 50, 15-53. Coseriu was familiar with Marr's linguistic ideas and distinguished orthodox Marrism from the original modifications given to his theoretical views by those few Soviet philologists who were also known to Freidenberg. 
Greek lyric," and from there to "the birth of tragedy" in Image and Concept.

Freidenberg treated the figure of the lyrical song-maker from the cognitive point of view and demonstrated that "the Greek lyric singer represented deified nature, but in a special form, no longer figurative, but conceptual." ${ }^{38}$ The way in which the new concepts were coming into existence was seen through "the self-consciousness of the singers, their thematics, their biographical myths; and through the form of the songs and the allocation of lyrical genres." This analysis of the birth of the main poetic categories in lyrical poetry made it possible to show "how Sappho was perceived through the categories of the goddess Aphrodite, how the image of Hipponax was molded after Hermes, how Alcaeus was depicted in Apollo's clothing, as the typological singer-soothsayer, by analogy to Apollo." ${ }^{39}$ In the West, C. M. Bowra, whose works Freidenberg knew and valued highly, came out with a similar interpretation of the figure of a lyric poet in ancient times. ${ }^{40}$ While Bowra believed that in Sappho's lyric the moments of divine significance and epiphany were shown as earthly occasions of nearly private dialogues between the poet and the goddess, Freidenberg proposed that the Greek lyric poet did not yet depict the intimate, immediate manifestations of the individual's love, loneliness, or longing. What one finds in Greek lyric poetry instead is the concrete, nongeneralized "fixation of elementary emotions which reveal either a state of Eros, or a burst of malice, a spontaneous joy upon the news of the death of an enemy, or yet a complaint about separation." ${ }^{41}$ Similarly, Eros, described by the Greek lyricists, "does not correspond to the feeling of love. It is rather a specific state of theophany, of passionate suffering, of the fatal, ruining, irresistible presence of a god in a miserable and weak human being." 42 Eros represents the external irresistible force that governs the feelings, the state of mind, and the entire life of a Greek poet. In other words, in early Greek lyric Eros is, once again, "an image in the function of a concept," and it draws its figurative connotation from its own concrete meaning.

Three published fragments from Freidenberg's monograph on Sappho reconstruct the correlations between the semantic clusters and their emotional connotations as well as the ways in which those correlations found their manifestations in mythological thinking and in philosophical and poetic discourse. The origins of Freidenberg's formative

\footnotetext{
38 Freidenberg, "Proiskhozhdenie grecheskoi liriki," 107. 39 Ibid.

40 Cf. Bowra, Greek Lyric Poetry, 195-200, and Freidenberg, "Safo," 190-98.

${ }^{41}$ Freidenberg, "Proiskhozhdenie grecheskoi liriki," 112.

42 Ibid., 113.
} 
categories are in semantics, yet once having come into existence, plot, genre, and metaphor develop, at a higher stage, new correlations of a semantic-syntactical order. Freidenberg traces various meanings of image/concept relations in different cultural and temporal settings, and thus ranges over Greek mythology, philosophy, music, poetry, and astronomy. This methodology suggests an affinity with Leo Spitzer and his combined study of historical semantics and history of ideas.

Like Spitzer, whose philological ideas maintained a connection to the neo-Humboldtian creed and philosophy of Ernst Cassirer, Freidenberg also explained the manner in which the things and phenomena of the objective world came to be named, known, and, to use Ernst Cassirer's expression, "constituted in the consciousness." ${ }^{33}$ She envisioned the relation between the concepts and that to which they apply in the spirit of Cassirer's Essay on Man, whose statement "Not nature, but society is a true model of myth" she wholly supported. "Furthermore, Freidenberg believed that since the limits between the different spheres of life and collective experience were viewed as fluctuating rather than insurmountable barriers, a metamorphosis, or a metaphorical transference of meaning went along and across the divisions between the cognitive modes and discourse genres. ${ }^{45}$ Presided over by an individual goddess in the family of Muses, each of the ancient sister arts was able to internalize the subject matters and aesthetic plots of other arts in their integrity and to comprehend dialectic oppositions and differentiations as a harmonic synthesis. ${ }^{46}$ Similarly, according to Spitzer, both the Pythagorean and the Heraclitian systems "confront us with the two antagonistic forces of harmonious unification and discordant manifoldness, but the symphonias, the 'thinking together,' is triumphant, the discordant is made subject thereto." "The linguistic expression itself," Spitzer added, "portrays the wrestling with chaos and the triumph of cosmos." 47

Using their semantic approaches, Freidenberg and Spitzer demonstrate how the same ideas were thought of, envisioned, and verbalized in different areas of collective cognitive experience. In order to trace "a

${ }^{43}$ It is positively known from Freidenberg's biography that in the late 1940 s1950 s, she had no access to works of Western scholarship. Therefore, although the affinity of her and Spitzer's approaches originates in their common knowledge of Cassirer, the similarity of themes and approaches can be treated as a parallel development. On Spitzer's connection to Cassirer and Vossler, see Wellek, preface to Classical and Christian Ideas of World Harmony, vi, ix.

${ }^{44}$ Cassirer, An Essay on Man, 79.

${ }^{45}$ See also our discussion of the Poetics of Plot and Genre, chap. 8.

${ }^{46}$ Freidenberg, "O proiskhozhdenii grecheskoi metriki," 290-93.

${ }^{47}$ Spitzer, Classical and Christian Ideas of World Harmony, 9. 
recurrence of words suggestive of the fundamental unity of the harmonizing unification of certain concepts (concordia, consonantia, temperare)" which were used to describe characteristic features of the mythical world, ${ }^{48}$ Spitzer follows the semantic history of two "word families," the first of which suggested the general idea of "order," and the second of "consensus" (accordance). This is precisely the focal point of Freidenberg's study on the origin of Greek metrics: "Structurally, Greek philosophy is always preoccupied with the primary elements, and along with that, philosophy remains within the framework of the dialectical opposition of two basic compounds, the motive forces of these primary elements. The contraposition and unification of the two opposite primary elements is the fundamental structural specificity of Greek philosophy." ${ }^{49}$ The ancient, divine, yet anthropomorphic concept of the universe associated with music the notion of order: of the seven celestial spheres (the world soul), of concord in one's psyche (the human soul), of commonwealth (the whole body of a people in the state), and of the consensual development of the entire system through time, which, in its turn, was conceptualized as an entirety, ordered, measured, and divided into units.

To conclude a brief survey of Freidenberg's contribution to the history of ideas (to "historical aesthetics," in her terms), it should be noted that, like Leo Spitzer, she was interested in manifestations of isomorphism of the micro- and macrocosm, and applied her knowledge of microstructures (etymology and morphology of the word, the inner form of the word, and rhythmical and metrical pattern of the verse) as an interpretative strategy for an understanding the universal meaning. For her this meaning was subsumed by the semantics of cultural forms of Greek antiquity.

48 Ibid., 80.

${ }^{49}$ Freidenberg, “O proiskhozhdenii grecheskoi metriki," 291. 
Chapter 11

Image and Concept: The Last Major Study

\section{A. The Onset of the Anti-Marrist Campaign and Freidenberg's Retirement from the University}

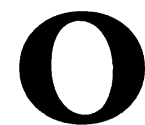

n 9 May 1950, the newspaper Pravda began its infamous "Free Discussion of N. Ia. Marr," which became a nightmarish carnival as soon as Stalin contributed to it his "Marxism and the Problems of Linguistics."1 As Freidenberg put it, "Stalin, the conjurer, the circus magician, assumed the role of a humble, ordinary reader defending the freedom of personal opinion.... Stalin annihilated Marr, a scholar whom he himself had created and encouraged." 2 The totemistic character of Stalin's rituals had been, as it were, described in advance in Freidenberg's early works on pharmakoi, human slaves whose lives were sacrificed in expiation for the sins of the community, on behalf of the prosperity of the ruler and of his kingdom. ${ }^{3}$ In these ritual performances, the ruler's slave and retainer was used as a scapegoat: he who used to serve as the ruler's bodyguard was designated to undergo torture, public defamation, and beheading. According to the law of "magic participation," the ritual performances lead to purification of the community. Similarly, Marr's "new teaching on language," which after his death in 1934 had been forcibly imposed on the Soviet humanities, was

\footnotetext{
${ }^{1}$ Pravda, 20 June 1950.

2 Mossman, Correspondence, 302.

${ }^{3}$ O. Freidenberg, "Iz do-gomerovskoi semantiki," 381-92; idem, Poetika siuzheta i zhanra, 151-56; idem, "K semantike fol'klornykh sobstvennykh imen Makkus i Maria," Sovetskoe iazykoznanie 2 (1936): 3-20. Similar rituals of purification have recently been described by Jacques Derrida in "Plato's Pharmacy," Dissemination (Chicago: University of Chicago Press, 1981), 120-30. Both Freidenberg and Derrida relate the "masterplots" of the sacrificial rituals to the development of new genres and to the concept of Logos. However, their "epistemologies" of genres and interpretations of Logos are fundamentally different.
} 
now anathematized and the followers of Marrism were subjected to denunciation and purges.

Although Freidenberg did not subscribe to Marr's teachings in toto, the idea of betraying the memory of the teacher who had fallen from grace was repugnant to her and she did not attend any of the "penitential orgies." But "on 30 June 1950, the last day of the academic year, one such witch hunt took place in our department and I was the witch" (15: 138). During the trial Freidenberg did not keep silent and assailed her accusers, but the outcome was a foregone conclusion: she was forced to resign her chair and retired soon thereafter.

With the loss of the chairmanship in her department, life lost all meaning for Freidenberg. With no scholarly activities she could not go on living. On 10 September 1950, she added a page to The Race of Lifethe page which she meant to turn into the epilogue to her memoirs. Again she writes about the age of Stalinism, projecting the bombastic celebrations of Stalin's birthday (he turned seventy on 21 December 1949) against the background of the event that prooundly shocked the consciousness of the whole world: the Nuremberg trials. Against this backdrop, she concludes:

Basically, that's all I have to say about my life. What kind of an epilogue will there be and what will be its meaning? Whether I will last much longer or not is devoid of semantic content. Nature endowed me with an abundance of moral resources and talents, but I exhausted them all in endless struggles and unavailing efforts to resist the state's machinery of repression and massacre.... And yet this is not the worst of it. The worst horror of all is the Siege to which I bore witness, this stripping of the skin from a living being that no one's soul can endure. The Egyptian Book of the Dead was less horrible than these entries in my diary.... I do not know when and how I will die. But one thing I know: if I remain conscious when dying, two images will be before my eyes-my mother and the Moscow Nuremberg trial.

Вот, собственно, и все о моей жизни. Какой может быть эпилог, и в чем его значение? Проживу я долго или мало, это уже асемантично. Природа дала мне изобилье моральных сил и способностей, но я их утрачивала в непрестанной борьбе, где я тщилась противостоять государственной машине насилия и убийству заживо.... И все же это не самое ужасное. Самое ужасное - осада, которую я увидела воочью, то скальпирование живого человека, перенести которое не может ничья душа. Египетская "Книга мертвых" была менее страшна, чем эти записки.... Не знаю, когда и отчего я умру. Но одно знаю: если я буду умирать в сознаньи, в моих глазах 
будут стоять два образа - моей матери - и московского Нюренберга. (15: 153)

Upon her retirement in September 1951, Freidenberg wholly concentrated on her scholarship. Her life resembled the voluntary seclusion of a religious dissident or an internal émigré. In her remoteness from the outside world, she made exceptions for a very small group of former colleagues and female friends (those whom she had known since the days of her youth) and for the exchange of letters with Boris Pasternak. This correspondence and her reading of Pasternak's translations from Shakespeare and of his poems from Doctor Zhivago enabled her (through him) to experience "the singular joy of recognizing her kinship to art." The phrase, borrowed from Freidenberg's letter of 17 July 1954 to Boris Pasternak, was written a few months after the completion of her last ground-breaking study, Image and Concept. ${ }^{5}$

Image and Concept continued the Poetics of Plot and Genre, and discussed the birth of ancient Greek literature from mythology and preliterary folklore. Proceeding from the tacit assumption that the mind's seeing (umozrenie) and perception by the senses are distinct, but invariably conjoined, Freidenberg treated the antinomy of the real and the apparent as a proposition whose validity could be most persuasively demonstrated through the history of ancient Greek thought, literature, and aesthetics. Image and Concept provided an overview and a condensed summary of Freidenberg's works written during the Siege (Theory of Ancient Folklore) as well as of those (like the Sappho monograph with an excursus into "The Origin of the Greek Lyric") which she started, but then put aside for the sake of completing Image and Concept.

\section{B. A New Formulaic Expression for the Antinomy of the Real and the Apparent}

In her last work, Freidenberg was inspired by the revelation of the "primordial and everlasting essentiality of the inequality of semantics and its morphology" that "had been opened up" to her on 25 February 1943 (9: 46). In the diaries Freidenberg formulated this revelation as a philosophical postulate about semantics and being: "Semantics had always to remain invisible in the background; being (bytie) I saw as a morphology with its own new qualities-new in relation to the semantics" (9: 47-48). In Image and Concept that very principle developed into a thorough study of the reciprocal relations between that which really is,

\footnotetext{
${ }^{4}$ Mossman, Correspondence, 330.

${ }^{5}$ Obraz i poniatie, 223-622.
} 
and how it is "seen as." That is, the perceivable form of the image is never identical with the form of the concept, but every perceivable form (or image) manifests its own content and through that manifested content represents the invisible concept as something different from, yet comparable to its perceivable appearance. From the standpoint of the theory of meaning, Image and Concept provided a thorough examination of the various relations between signs and contexts. From the standpoint of "historical aesthetics," the work offered a new view of the figurative depictions, or representations, based on metaphors, similes, as well as narrative descriptions made up of both direct and indirect discourses. Image and Concept also offered a new interpretation of the origin of theatrical performances and other types of spectacles. As a whole, Freidenberg's study provided a thorough analysis of the reciprocal social interactions defining the relations between the creative subject and the object (between the ancient author or poet and the addressees of his invocations, as well as between the author and the world sung by him).

The connection of Image and Concept to Freidenberg's earlier writings is as strong in this work as the difference between her treatment of the complete identity of semantics and its morphology (the central problem that interested her in the late 1920s-1930s) and the "primordial and everlasting essentiality of the inequality of semantics and its morphology" that "had been opened up" to her on 25 February 1943 (9: 46). As I showed in chapter 4 , in the 1920s-1930s Freidenberg treated the puppet and the puppet theater, for example, as a cultural form synonymous with the particular content of being: the doll and the construction of the theater served simultaneously as a representation of a deity and its heavenly dwelling; of human beings in their earthly dwellings; and of the dead in their graves. In the 1940s, however, (in lectures 9, 10, and 18 of her Theory of Ancient Folklore) Freidenberg emphasized the moment of non-identity between the form of the myth and its content. ${ }^{6}$ As any cultural form, the "morphology of myth represents a different quality of the inner meaning, such a transformed, different quality of its inner meaning that without a scientific analysis it is hard to believe in their constituting a complete organic unity."

Thoroughly revising her own and Marr's ideas of the $1920 \mathrm{~s}-1930 \mathrm{~s}$, Freidenberg now insists that the mythic hero is a cosmic category in its content, although morphologically the hero is always a concrete being. The mythic hero dwells in the "real" world, and his surroundings are similar to the daily life of primitive man. "The entire narrative function of the myths and the entire character of their external incarnation into outward human form (kharakter ikh vneshnego ochelovecheniia) consti-

\footnotetext{
${ }^{6}$ Lektsii, 60-72, 129-36.

${ }^{7}$ Ibid., 60.
} 
tutes their formal aspect. The latter substitutes for the abstractness of mental representations (abstraktnost' vospriiatii), which are as yet unknown in this epoch." 8 Thus, the circular form of the ancient city square and its localization in the center of a settlement substituted for the centrality and focal position of the round sun in the sky. This theoretical proposition reappears again in Freidenberg's Image and Concept, where she argues that pre-literary mythological images are not obsolete representations which were replaced by concepts. Mythological images did not disappear, but continued to be present inside the abstract concepts that marked the birth of ancient literature. They continued to be present, moreover, without losing their primordial form and without entirely canceling out their concreteness or materiality. Freidenberg concludes, therefore, that "the concepts of early antiquity were, indeed, images that had merely changed their fundamental function."

Thus, in the mythological Dike/Hubris polarity, the concrete image of Dike stood for everything that is inside and cannot be plainly seen as it is: "truth, right (law), and rightfulness (justice) [pravda, pravo, spravedlivost $]$." 10 The real meaning content of Dike could only be seen by the mind-"seen as," and described figuratively by means of specific types of discourse. The other part of the polarity, Hubris, displayed everything that is apparent to one's eyes. Yet precisely because of its visible appearance, the meaning content of Hubris remains as unattainable as the inner form and content of Dike. The inner essence, or meaning contents, of both Dike and Hubris could only be seen indirectly"seen as." This is how Freidenberg describes the way in which images, by changing their fundamental function, gave rise to abstract concepts. This relationship of image and concept Freidenberg now placed at the base of her modified theory of metaphor.

Image and Concept, opening with the general "Exposition of the Theme" (chapter 1), is made up of six excurses into philosophy and poetics, each discussing the categories of figurative and conceptual thinking and their structures. Thus the entire study offers an overview of Freidenberg's "historical aesthetics." The translation of the concrete image-object into the image-concept (the specific category of abstract thought) is described in chapter 2, entitled "The Metaphor." This chapter offers an inquiry into the inner form, ideational contents, and architectonics of poetic tropes. Chapter 3, "The Origin of Narrating," (proiskhozhdenie narratsii) deals with the separation of the individual "I" (a poet as speaking and experiencing subject) from the object of narrating (the plot and the form of narrating). The result of this separa-

\footnotetext{
${ }^{8}$ Ibid., 62.

${ }^{9}$ Obraz i poniatie, 236.

${ }^{10}$ Ibid., 292.
} 
tion is that the narrating poet objectifies his narrating, that is, views what he is enduring as if "from the side." His narration of what he is enduring becomes a narrative (a literary form) about what he had endured. ${ }^{11}$ Or, in other words, his narrating is "seen as" an independent narrative with its own narrator and plot. For instance, Pindar's "Olympia I (To Hieron of Syracuse)" starts with narrating:

But if, oh, heart of mine,

Thou art fain to speak of contests,

Then look for no other star

Shining in daylight through the desert of the sky blither than the sun;

which then becomes a narrative about the hero:

Tis thence the many-voiced hymn ariseth that enfoldeth the thoughts of the craftsmen of song,

To raise the loud chant in praise of the son of Kronos, When they have come to the rich and blessed home of Hieron. ${ }^{12}$

As one can see, Freidenberg applies her "seen as" formula to the momentous separation of the cognizing consciousness from the world cognized. Thus she argues (on the basis of her earlier Pindar and Sappho studies) that the song created by the song-maker is still centered on the actual content of the myth: on the hero's deeds, on the trials he is destined to pass through, and on the victories he is rewarded with. The old mythic tale, however, is now perceived as the poetic discourse of an individual-an author-who addresses a human audience rather than the gods. Instead of almighty divinity, it is now an individual hero who occupies the center of the song-makers' performance. Thus the content of primordial myth, i.e., a narration about the gods and their deeds, does not yet disappear, but now is simultaneously presented as, "seen as" a narration about the hero and his deeds. This new form of narration produces what Freidenberg terms "an indirect narrative about what was done and endured" (kosvennyi rasskaz o sodeiannom i preterplennom) ${ }^{13}$ In this "indirect narrative" Freidenberg distinguishes "active" and "passive" components, i. e., the subject who performs deeds and the subject who endures deeds. The subject of deeds eventually becomes an author-narrator, whereas the subject of enduring becomes the hero of

11 Ibid., 267.

12 Pindarus, The Works of Pindar, trans. Lewis Richard Farnell (London: Macmillan, 1930), 3.

13 Obraz i poniatie, 267-68. See also the chapters "The Metaphor," 232-61 (dated 14 January 1951) and "Origin of Narration," 262-85 (completed by 2 February 1945). 
the narrative. The narrative takes on, therefore, a "twofold character: the narrative of action separates from the narrative of enduring, and the subject of the narrative [the narrating poet-N. P.] separates from the object of the narrative," the hero of the narrated plot. ${ }^{14}$

\section{The Archaic Mimos and the Origin of Greek Comedy and Tragedy}

In chapters 4-7 ("The Mimos," "Excursus into Philosophy," "On Ancient Comedy," and "Tragedy") Freidenberg argues that both Greek comedy and tragedy originated in the archaic mimos, performances by mimes. ${ }^{15}$ Freidenberg hypothesizes that on certain occasions the archaic community divided into two groups: into performers-the mimes-and into viewers of the mimos. The mimes displayed their artistry before the viewers: they showed sleight of hand and prestidigitations; they performed tricks and "mimicked." The mimes" "tricks" produced on the viewers the illusion of miracles performed before their eyes. That is, the viewers saw the illusions produced by the mimes as allusions to deeds performed by invisible or divine agents. As a result, the mimes' prestidigitations made things appear as if from nowhere and then disappear into the unknown. Thus the function of the mimes in the mimos was similar to the function performed by the author-narrator of "the indirect narrative." The mimos referred to the invisible divine deeds and their meaning, such as coming into being and creation; dying and destroying; manifesting and revealing the truth. Like the ancient poet (the subject of "the indirect narrative"), the primordial mime did not yet distinguish between the subject of his performance (mimos as a narrative with its specific plot) and the function (the role or part) he as a performer actualized in the given show. Throughout his performance, the mime "mimicked," and the resulting illusion achieved by this mimicking, i. e., the "mimetic aspect" of the mimos, manifested the twofold character of the Dike/Hubris polarity. Later on, with the appearance of what Freidenberg terms "the category of qualitativeness," the subject matter of the mimos became differentiated into what we know as the subject matter and the plots of the tragic and comic modes. Freidenberg's point is that comedy and tragedy did not arise from religious mysteries. They

\footnotetext{
14 Ibid., 268.

15 ML, "The Mimos" (dated 24 May 1951), 286-328; "Excursus in Philosophy" (no date), 329-44; "On Ancient Comedy" (no date), 345-71; "Tragedy" (dated 17 May 1953), 372-622. On 19 August 1954, after Freidenberg had completed the manuscript which she dedicated to "viator" ("wayfarer," i.e., the reader of the future), she added an eight-page "introduction to the theme," her chap. 1, 22431. Her chronological allocation of individual chapters bears witness to how her works lived through her days.
} 
both arose from the primordial, collectively performed mimos: the "moving pictures" produced by the mimes-the illusionists-ceased to be treated as produced illusions and assumed the qualities of indirect narratives about heroes and divine beings.

In addition, chapters 4-7 of Image and Concept traced further manifestations of "the invariable nonidentity of semantics and its morphology." If the separation of the subject of the narrative from the object of the narrative engendered the concepts of the narrating poet, of the hero of the narrated plot, and of lyric poetry, then the invariable nonidentity of the illusion produced by the archaic mimes' performance and the allusion to primordial myth determined the genesis of archaic comedy, tragedy, and of the ancient theater as a whole. Indeed, the essence of ancient theatrical performances consisted in the fact that the performers and their paraphernalia are "seen as," i.e., perceived and understood as something fundamentally different from what they are. ${ }^{16}$ The most obvious case of the nonidentity of an illusion and an allusion to primordial myth were the different facial features of ancient masks. In ancient tragedy, the mask retained mythological vestiges of "the cosmic stage." Instead of individual traits, it provided a metaphor for superhuman characteristics which were beyond seeing. In comedy, conversely, the animalistic design of the mask represented a human collective as a faceless mass and indicated such features as age, gender, or physical inclinations toward gluttony and lust. ${ }^{17}$

Freidenberg argued that both comedy and tragedy originated in the same archaic polarity, the polarity of Dike and Hubris, but the invisible yet "imagined" profiles of Dike and Hubris were intuited and expressed by comedy and tragedy through different figurative images, in different metaphors. Since "the true knowledge of the object" ${ }^{8}$ remained unattainable through human senses, the performance constituted an illusion produced by the enactment before spectators and only through allusions did it refer to the core of the unattainable and therefore $a b$ stract image. The mask of the comical actor represented and exhibited everything that was hidden behind the profile of Hubris; just as the illusion produced by the ancient mime's grease-painted face referred both to the true and the apparent profiles of Hubris.

\footnotetext{
${ }^{16}$ Freidenberg's claim of the nonidentity of semantics and morphology is comparable to the structuralists' and semioticians' claim of the signifier-signified polarity. However, Freidenberg was not familiar with this terminology, and wherever possible, I avoid terminological "bilingualism."

17 Obraz i poniatie, 358.

18 Plato, "Seventh Letter," 343, trans. L. A. Post, quoted in The Great Thinkers on Plato, ed. Barry Gross (New York: Capricorn, 1968), 3.
} 
It is Freidenberg's conviction that the traditional linking of the comical and comedy, and the treatment of the former as an attribute of the latter, obfuscates the fact that "archaic comicality" (drevnii komizm)-pre-literary, pre-qualitative comicality-is more encompassing than comedy. ${ }^{19}$ From the standpoint of genesis, all genres, beginning with epos, carry elements of the comical within themselves. One finds no comediality (komediinost) in The Iliad, but one can easily find, as in epos in general, comicality and comic laughter in it. In epos, the comical always relates to the gods, and not to the heroes. The heroes (those born as mortals and rewarded with immortality for their feats) never laugh, and their actions never elicit laughter. As for the gods, they make up two groups: those who laugh and smile, and those who do not. Solar deities (divine life-givers) and gods protecting fertility and fecundity smile and laugh frequently. Conversely, chthonic deities, virgin goddesses, and Apollo (the bachelor among the Olympians) never smile (Freidenberg assigns Poseidon, Hades, Hephaistos, Ares, and the virgins Athene and Artemis to this group as well). Homer's gods ridicule each other after their scuffles and brawls. With laughter and smiles on their lips, Zeus and Hera go to their bed. Episodes of laughter precede the love scenes; laughter is a component of hierogamy, which represents the rejuvenation of life and beauty on earth. Following Dieterich, Freidenberg traces Homer's epic laughter to archaic rituals of the insemination, the reviving, and the awakening of nature. ${ }^{20}$ Cultural survivals of ritual laughter are transferred to other products of archaic folklore and form concrete images which can be interpreted as abstractions, as metaphors, and as specific characteristics of different poetic genres. In The Iliad, for example, Freidenberg points out that Hephaistos entreats his divine parents and other Olympian gods by recounting to them how he was caught by the foot and thrown from the magic threshold by his father, Zeus; upon landing at Lemnos, Hephaistos became lame. The god's ridiculous katabasis and his limp are recognizable as a cultural survival in the choliamb (literally "lame iamb"), the most ancient verse pattern used in archaic comedy. ${ }^{21}$

In epics the comic behavior of the Olympian gods was duplicated in the fisticuffs, single combats, quarrels, agons, and in the mutual obscene abuse of the heroes. In The Odyssey, for example, the agon of the heroes

19 O. Freidenberg, "Komicheskoe do komedii," 74-127. The main ideas of this work, written in 1942-44, as well as of her "Palliata" (1945-46) (ibid., 36-73) were briefly summarized in Image and Concept, in different subchapters dealing with the origin, the organization, and the main metaphors of ancient comedy.

20 A. Dieterich, Pulchinella. Pompeianische Wanderbilder und romische Saturspiele (Leipzig, 1897), 34.

${ }^{21}$ Freidenberg, "Komicheskoe do komedii," 74-75. 
duplicated the agon of the gods. Similarly, in other forms of archaic folklore, single combats constituted the very core of city square performances: of balagan and comedy. Freidenberg insists that in Homer, "epic gods are not subverted by mockery, yet they are undoubtedly depicted comically," 22 that is, "cosmic order" becomes manifest through comic details on the plausible, realistic plane. In epic poetry the cosmic is shown as realistically plausible; yet the archaic comicality is not comedial here. Archaic comicality stems from the cognitional interpretation of the most serious noncomical aspect of Hubris, i.e., it offers a hubristic representation of the serious. ${ }^{23}$

The question is: what makes the comical features of the Olympian gods different from the comedial features of heroes in farces, comedies, novels, and facetiae? Freidenberg contends that the difference between archaic and comedial comicality is conditioned by the presence or absence of the "category of quality." Even the most plausible, "realistic" depictions on the divine plane lack the abstract category of quality. This is why epic gods are, in fact, not ridiculed when they are depicted comically and elicit laughter. When the archaic community was confronted by comical features in the divinity, the community understood these comical features as a cosmic agon in which life triumphed and death was humbled and ridiculed. It was only when the archaic community came to see in Zeus, for example, the ludicrous characteristics of a deceived husband that comedial comicality became possible. Thus the original cosmic laughter was internally restructured into various poetic forms; each form conveyed its own specific semantic qualities of the comical. Cosmical laughter and epic comicality found their legitimate place on earth, in the city squares, where under the guise of comedial masks they came to be understood and represented as individual, qualitative features of human characters. But since the connections to the life-giving cosmic plane were not effaced from the collective memory, various forms of city square festivities or celebrations (carnivals, farcical performances, festive pageants, epinicons, vituperation [aiskhrologia]) duplicated the cosmic plane, without divesting divine life of its divine nature.

\section{Epic and Comedial Laughter or the Comical before Comedy}

As one can see, within the context of archaic folklore and ancient literature, Freidenberg distinguishes two fundamental types of laughter: epic laughter and comedial (balagan, carnival, parodic) laughter, of which only the latter was enacted as a public performance. Epic and comedial laughter were constituted by different types of the comical, of which

22 Ibid., 80.

${ }^{23}$ Obraz i poniatie, 369. 
only comedial laughter was allowed to make qualitative judgments about the heroes. ${ }^{24}$ Freidenberg believed that Attic comedy and the comedies of Aristophanes embodied a new quality (a "specificum"), a new relationship to an object that enabled the recipient to perceive comical features of the object. One should recall that for Freidenberg the archaic community constitutes the collective subject, while what the community sees constitutes the object. A new quality was the result of the lack of identity between the subject and the object, the "self" and the other, the real and the apparent, the concept and the image. "If an actor wears a mask, this means that another member of the collective acts in the image or figure of the actor." ${ }^{25}$ The formula "seen as" which Freidenberg used to determine the origin of the Greek lyric, is also used to explain the genesis of archaic comedy and tragedy.

Freidenberg worked out this approach in her interpretation of precomical and comedial laughter, and she went on to apply it to the analysis of Greek tragedy as well. As with comedy, tragedy existed in the form of genres which contained no tragic elements. Freidenberg approached "the formants" of tragedy as recurrent components of a system of thought, within which they were so rearranged that the community could see them as "tragic"; that is, they were reconstituted into elements of a new type of consciousness, a specifically aesthetic consciousness. Contrary to the generally accepted interpretation, Freidenberg traced the origin of tragedy not to cultic mysteries, but to the mimos, to the shows and pageantries produced by "illusionists" (the mimes) in city squares. ${ }^{26}$ She did not deny the links between tragedy and religious mysteries. Rather she argued that these two genres conveyed the archaic substratum of cult, myth, and ritual in an entirely different way. The plots of tragedies and mysteries were based on actions and preexisting mythological themes. Yet the structure of tragedy was different from any other public performance or show. What Freidenberg terms "structure" should not be mistaken for composition, i.e., the established disposition of parts. The "structure" is independent of the order in which the parts of a tragedy are arranged. What Freidenberg calls "structure" is the structure inherent in the primordial subject matter of myth; this structure determines the possible interpretations and

${ }^{24}$ This opposition which develops within the category of the comical explains the phenomena that Bakhtin defined as "the privileges of laughter in antiquity and in the Middle Ages." See his Problems of Dostoevsky's Poetics, trans. and ed. Caryl Emerson (Minneapolis: University of Minnesota Press, 1984), 127. For a further discussion of Freidenbergian and Bakhtinian theoretical poetics, see chap. 13.

25 Obraz i poniatie, 358.

${ }^{26}$ Ibid., 515. 
arrangements of the plots of the play. The underlying structure of The Seven against Thebes, for example, was constituted by the known mythologeme "a curse upon the house." But this structure is presented through an ekphrasis, or indirect narration, by a messenger about the hero's inner states and acts that cannot be seen from outside, such as the hero's anguish, or his intention to burn down the city. Similarly, the messenger's arrivals and departures inform the spectators about the death of the hero.

In tragedy the departures, arrivals, and pleas serve as constructional elements which constitute its structure, that is, its organic skeleton. In the lyric a serenade is a song of arrival and a plea for arrival ("show yourself," "come forth," "open the door or the window"), whereas an alba is a song of departure ("the sun is rising, farewell"). In tragedy the parodos is the arrival of the chorus that organizes the beginning of the action, and the exodos is the departure of the chorus that organizes the end of the action. The soloists are also "those who appear" and "those who depart"; their "appearance," along with their departure, constitutes the structural essence of drama. ${ }^{27}$

Thus, Freidenberg concludes, the structure of a tragedy is the specificum that conveys the substratum of the primeval myth through new metaphors.

\section{E. Freidenberg's Conception of a Pre-Aristotelian Metaphor}

Freidenberg's conception of metaphor differs from the "Aristotelian and neo-Aristotelian," as well as from modern "non-Aristotelian" conceptions in classical studies and in semiotics. ${ }^{28}$ In the "Introduction" to her new theory of metaphor, Liselotte Gumpel labels as "neo-Aristotelian" the theory of tropes whose progenitor is Aristotle (although, in fact, he may not have been the first theorist of metaphor). According to Gumpel, "the main trouble of the neo-Aristotelians" is that in their theories "metaphor never made the transition from the field of rhetoric to semantics." In opposition to the neo-Aristotelian approach to metaphor, Gumpel advocates a "non-Aristotelian" perspective of "intellectual

${ }^{27}$ Ibid., 377.

${ }^{28}$ Liselotte Gumpel, Metaphor Reexamined: A Non-Aristotelian Perspective (Bloomington, IN: Indiana University Press, 1984). I borrow Gumpel's terms "Aristotelian, neo- and-non-Aristotelian," as well as her contrastive examples of various theories of metaphor. 
introspection," which enables one to observe "how the words acquire their explicit and implicit contents."29

In contrast to the non-Aristotelian point of view, Freidenberg's position may be defined as pre-Aristotelian. First, as is made clear in "The Comical before Comedy," Freidenberg invokes an archaic substratum of myths and presents pre-literate forms of folklore as categories that lend themselves to further semantic analyses. Second, instead of discriminating between rhetoric and semantics (as the non-Aristotelians do) Freidenberg provides a theory of metaphor which serves as a foundation for rhetoric-the discipline which proposes consensual rules for the efficient organization of semantically charged communicative structures. ${ }^{30}$ In other words, if Gumpel's non-Aristotelian perspective plays down the Aristotelian point of view, Freidenberg, in contrast, provides an epistemological foundation to Aristotle. She demonstrates how various verbal arts acquire their specific characteristics and how verbal art produced from within itself poetics as a distinct cognitive category: everything that "had no poetic function beyond the limits of Greek literature, began to acquire within that literature itself the characteristics of poetic forms." ${ }^{31}$ In early antiquity, the polysemic, nonspecific qualities of pre-literary folklore developed into specific, individual aesthetic qualities in lyrical poetry, in drama, and in narrative genres.

The components of collective experience which remained as unattainable as ever to sense perceptions (abstractions like "law," "suffering," etc.) are now seen through the mind's eye as figurative images and image-concepts. Thus, suffering is perceived as analogous to the pangs of childbirth; and the law is envisioned as a meadow (this image-concept is clearly perceivable in the title of Moschus' "Spiritual Meadow" as inner form as well as the ethical and aesthetic premise of the work). The difference between the concrete and figurative image produces allegory, inoskazanie, as a specific form of mental pictures. In her vivid depiction of how allegory comes into being as a new category of thought, Freidenberg writes: "The image ceases to pursue the exact reproduction of what is being conveyed, and instead foregrounds the interpretational meaning. The image "tells 'otherwise' that which it

\footnotetext{
${ }^{29}$ Ibid., 1-3.

${ }^{30}$ In "Excursus into Philosophy," chap. 5 of Image and Concept, Freidenberg provides an overview of Socrates' "epagogic method," which "arrives at a general definition of an abstract by successively passing through all the stages of particular concepts" $(339,340)$. Freidenberg also notes the demonstrative, "epideictic" methods of orators and rhetors of the post-Socratic and preAristotelian time. See $M L, 338-44$.
}

${ }^{31}$ Ibid., 232. 
sees. ${ }^{32}$ Freidenberg emphasizes the cognitive function of allegorical discourse:

[T]he image's "telling it 'otherwise"" has a conceptual character: the concreteness takes on abstract features; the singularity takes on features of repeated occurrence; the absence of qualities is filled with distinctly outlined (initially monolithic) qualities; the space widens; the factor of movement from a cause to its result is introduced. The former mythological image gains meaning, an "other" meaning of itself, of its own semantics. The image assumes the function of inoskazanie [telling it otherwise, as allegory]. ${ }^{33}$

Since the concrete mythological image is not effaced from cultural memory, the process of transition from concreteness to abstraction catalyses the constitution of different cognitive forms of the collective Weltanschauung. Not only does allegorical discourse speak "otherwise" about the picture of the world, it generates and foregrounds a new opposition in philosophical semantics, the opposition between "being" and "imaged being " Thus, what Freidenberg herself formerly viewed as a polar phenomenon, as a polarity of internal identity and external variety, is now viewed from the perspective of nonidentity. Nonidentity introduces a correlation, yet precludes the confluence of image and concept, of form and content. Quoting the same definitions of allegory as I do, Kevin Moss suggests, with good reason, a parallel between the "genetic semantics" of Ol'ga Freidenberg and the structuralist and semiotic views of Levi-Strauss and Terence Hawkes, who propose "a logic ... which confirms the active presence of a code 'by means of'" in the archaic picture of the world. ${ }^{34}$

The dissimilarities between Freidenberg and non-Aristotelian poststructuralism are, indeed, considerable. According to the nonAristotelian schemata, "the traditional metaphor straddles a momentary collision between logic and language." ${ }^{35}$ According to Freidenberg, in the classical metaphor the intuited concreteness and the conceptual do not collide, but rather support each other. In the non-Aristotelian view, the epistemological origin of metaphor is located in the author's/ interlocutor's "shaping competence of intrinsic semantic associations." 36 Freidenberg never fails to emphasize that although the ability of ancient consciousness to produce poetic tropes in language is limited to the

32 Ibid., 239.

33 Ibid., 242-43.

34 Moss, “Olga Mikhailovna Freidenberg," 134-37.

35 Gumpel, 3.

${ }^{36}$ Gumpel, 27. 
collective, mythological character of communal worldviews, the correlation/nonidentity of being and imaged being remains valid in all cultures. But it is only in ancient Greek literature that the poetic metaphor owes its origin to primordial myths and communal folk beliefs, conveying the archaic meaning content through new poetic structures. For example, in "The Origin of the Greek Lyric" Freidenberg juxtaposes two fragments of Archilochus and a passage from Pasternak's poem "The Artist":

What is honor and fame to him,

At the moment when by breathing fusion

Words are mold in worlds?

For that he'll burn up furniture

And friendship, reason, conscience, and everyday existence.

On his desk-a glass half-emptied,

A life unlived to the end, and the whole world forgotten.

Что ему почет и слава,

Место в мире и молва

В миг, когда дыханьем сплава

В слово сплочены слова?

Он на это мебель стопит,

Дружбу, разум, совесть, быт.

На столе стакан не допит,

Век не дожит, свет забыт. ${ }^{37}$

The point of the juxtaposition is that in Pasternak "there is a new microcosm ... but there is no mythologism." "38 In Pasternak's poem, "the moment of creative self-oblivion is figuratively expressed by the fact that a half-empty glass is left on the table like an abandoned world. That is why the metaphor of the half-empty glass is located on the same plane as the metaphors of the century not lived to the end and of the forgotten world. The creator's grandiose self-oblivion is symbolically conveyed by that half-empty glass. Creativity and the glass have nothing in common; they constitute two different planes. The metaphor and the designative meaning are disconnected. There is infinite freedom, vast space between them. The whole world forgotten, a life unlived to the end, and a glass half emptied constitute the parallel planes of small-

37 "Proiskhozhdenie grecheskoi liriki," 113, 116. References are to Archilochus' fr. 104 (266, according to François Lasserre's designation of the texts of Archilochus) and 112. Freidenberg uses V. V. Veresaev's translation; she quotes two quatrains from Pasternak's third poem, "Khudozhnik," from his cycle "Na rannikh poezdakh."

38 "Proiskhozhdenie grecheskoi liriki," 117. 
scale life (the glass) and large-scale life (the century, the world). In Pasternak, there is a new microcosm, constituted by all the things and objects he designates, but there is no mythologism in them." ${ }^{39}$ In other words, unlike the ancient Greek metaphor, Pasternak's metaphor does not draw its figurative meaning from its denotative meaning, but is based on the modern correlation between the micro-and-macrocosm, which did not exist in Antiquity. The new kind of metaphor is a reflection of the cultural horizon perceivable only by the modern poet and makes possible a vertical multilevel system of images.

According to non-Aristotelian theories, the semantics of postmodernist metaphor is created by breaking grammatical rules and twisting literal meanings. The principal dissimilarities of pre-Aristotelian (Freidenberg) and non-Aristotelian (Gumpel) treatments of metaphor can be seen from Gumpel's interpretation of a picture in a popular daily which shows a couple in the park during the fall. The inscription says: "That's why they call 'em LEAVES, Joe. They're all that's left of summer." ${ }^{40}$ As Gumpel believes, a pun that verbalizes the pictorial semantics of a cartoon exemplifies the structure of postmodernist metaphor, where "the graphic and orthographic zigzag" (as she terms the phenomenon) substitutes for the cognitional powers of language: a chance association between two discrete forms of two dissimilar lexemes is endorsed by a fictitious meaning. ${ }^{41}$ Postmodernist metaphors have no roots in cultural memory and present intertext as loose fragments amenable to momentary transformation into elements of discrete texts and contexts. Postmodernist metaphors are literally inter-subjective: their semantics depends entirely on the speech partners, and its validation needs an individual author plus his/her closest interlocutor.

If Freidenberg were interpreting Gumpel's cartoon, she would reject that the "Leaves leave" pun has a postmodernist origin and a fictitious meaning. She would argue that Gumpel's trope follows the mythological metaphor of the death and resurrection of the gods of vegetation, and that "the eternal chain of being" is not erased from the cultural memory of modern people. In ancient literature, the time span between midSeptember and the beginning of November, manifested by the seasonal disappearance of vegetation, was metaphorized as a withering, a wasting away. ${ }^{42}$ Although the homoforms "leaves" (noun) -"leave" (verb) are not found in Greek and in the vocabulary of many other languages (Russian, German, Italian), the observation that by the end of summer

${ }^{39}$ Ibid., 116-17.

40 Gumpel, 28.

41 Ibid., 29, 58-60.

42 Henry George Liddell and Robert Scott, compilers, Greek-English Lexicon (New York: Oxford University Press, 1996), 2035. 
"leaves leave" the trees provides the classical metaphor for autumn with a concrete meaning. Contrary to Gumpel, who insists on the postmodernist character of the metaphor in the "leafing-leaving" pun, the underlying mythological image-concept of this metaphor (withering, being consumed) was perceived and expressed, for example, by Aleksandr Pushkin in his elegy "Autumn," where a parallel is drawn between the wasting away of vegetation and a young girl wasting away from consumption. The same image-concept is found in O. Henry's story "The Last Leaf," where a skillfully produced artifact (a green ivy leaf painted on the wall in a dreary yard) instills in a young girl suffering from pneumonia the desire to regain health and prevents her from wasting away. $^{43}$

Freidenberg's pre-Aristotelian metaphors are constituted by associations ingrained in the consciousness of the speaking collective. Her theory of metaphor originates in meanings inherent in cultural memory. The theory establishes a relation between signs and contexts (that is, the sum of experiences shaped as collective worldviews), and it describes different modes in which that relation is realized. In addition, she offers an analysis of the conceptual content of metaphor. That is, she traces acausal and causal relations within the modes of archaic thinking and arrives at the conclusion that, regardless of whether the sensorial or the contemplative mode prevails in a particular epoch, metaphor cannot be limited to iconic descriptions of simply seeing. For metaphor always presupposes and actualizes some aspect of "seeing as."

In order to understand fully Freidenberg's epistemological treatment of metaphor, one needs to take into account her study "The Origin of Epic Simile (On Material from the Iliad )." It was this study which probably enabled her to formulate the distinction between being and forms of being. As with "The Comical before Comedy," which argued that comicality is more archaic than "comediality," Freidenberg begins with the claim that "animal similes are more archaic than the heroes of The Iliad, who took on human form and character." In the epic simile, the comparison was taken from the world of the animals, and the mythological image was perceived as a nonidentity of two heterogenous components. "At the realistic plane it was a comparison, at the mythologicalan identity." 44 From the genetic and mythic point of view, that which is being compared and that to which it is being compared are of the same nature, yet in terms of morphogenesis they are functionally contrasted. In an epic simile, a hunting scene, for example, that provides the subject

${ }^{43}$ Aleksandr Pushkin, "Osen' (Otryvok)," in Polnoe sobranie sochinenii v desiati tomakh (Leningrad: Nauka, 1977), 3: 247; O. Henry, "The Last Leaf," in The Complete Works (Garden City, NY: Doubleday, 1953), 1457, 1459.

${ }^{44}$ O. Freidenberg, "The Origin of the Epic Simile," SSL 27: 3 (1991): 22. 
of a likening, makes the image of a human being closely connected with the animal world, but the anthropomorphic image of the animal by which the likening is conveyed presents the animal theme as an attribute of human ethical disposition. ${ }^{45}$ The interaction between that which is seen in the animal world and that to which the scene is applied in human life produces the extended simile, which approaches narrative. ${ }^{46}$ The sensuous images of the animal world begin to work as indicators of human temper, of communal morals, and mental concepts.

Epic similes introduced new lexical meanings into a total stock of morphemes in a language. Originally, the morpheme "ethos" meant merely a "disposition, a habit." But when used as an attribute of the subject of comparison, it acquired the connotation of "someone's temper," nature, frame of mind. As poetic tropes, similes contributed to the polysemy of language, for they rendered abstractions as visual concepts. Syntactically, the conjunctions "like," "as," "so that," and "as ... so" interconnected the parts of comparisons in similes. From the narrative and logical standpoint, however, the removal of a conjunction made possible the immediate juxtaposition of images that belonged to dissimilar planes of cognition. The result was the transformation of extended epic similes into new narrative genres, such as ekphrasis, narrative description, gnomes (wise pithy sayings), and fables.

The twofold correlation of mental images and apparent images remained valid for all cognitive structures and for the architectonics of all speech genres of the collective. The structure of metaphors and the concept of the speaking subject followed the same pattern in religious teachings, philosophy, history, and verbal arts. Although dissimilar, these speech genres offered similar methods of interpretation of the world. As a category of collective thinking, each discourse genre functioned as a conveyor of a specific semantics. For example, in religious ritual a sacrificial offering placed at the altar substituted for the life of a supplicant, and in this capacity served as a manifestation of the object/ subject relation. Similarly, in ancient literature ekphrasis (the poet's narrative, the invocation) was delivered before the altar to the invisible

\footnotetext{
45 Ibid., 22-23.

${ }^{46}$ Steven $H$. Lonsdale comes to the same conclusion in his excellent study Creatures of Speech. See pp. 125 and 126: "The anthropomorphic portrayal of the animal results in linguistic unity between simile and narrative. The overlap of animal imagery and narrative at the level of diction is complemented by resemblances between simile and other contexts in form and theme," and "By means of an illuminating image, the simile momentarily suppresses the narrative event, transposing the action at hand to another register. The actor and the event are recast and reintegrated."
} 
deity. The ekphrastic supplication expressed a new, metaphorical, correlation between image and concept, subject and object.

The fixed, static figurativeness of time/space relations in classical antiquity also had its linguistic and philosophical expression. For example, Freidenberg points out that the subject-object correlation between the components of discourse in ancient Greek was morphologically expressed in accusativus cum infinitivo, that is, a grammatical construction which fused the notions of the active subject and the passive object, of the speaker and of what was spoken of. ${ }^{47}$ The grammar and the "scenario" of dramatic performances demonstrated that the trials and deeds of the heroes took place somewhere between eternity and the retroverted "future in the past"; the latter served to fulfill predestination and made the fulfillment of foretelling inevitable. The eternal and invisible truth (Dike) made itself known everywhere through Hubris. The various categories of consciousness (poetry, ethics, philosophy, and soothsaying) were all preoccupied with penetrating the exterior of disguising Hubris to arrive at the invisible Dike. Yet the metaphorical enactment of covering and disguising, of veiling and unveiling was presented by comediographers, tragic poets, and philosophers through different sets of similes and metaphors and on different emotive and rational planes.

In tragedy

artistic mimesis, enriched by ethical ideas, takes on the form of collision between the apparent and the true. This fundamental conflict finds its manifestation not only in agon and peripeteia, but also in the atmosphere of moral delusion surrounding the hero-in his errors, in his moral blindness and unawareness.... The conflict of Greek tragedy presents a collision not between the right and the wrong, but between the blind and the seeing, between the seeming and the true, between the ignorant and the wise.

This collision between error and truth leads to the death, expiation, purification, and regeneration of the hero.

The hero sees the truth at the moment of death. Every death is a seeing of the truth, every seeing of the truth is a death.... In tragedy, the ethical character of the purification of the spectators, originating in ethical mimesis, i.e., in the overcoming of the false in the true, expands into a deep allegory.... The Greek theater achieves this generalization through a complete balancing of fact and meaning. It expresses the idea through a

${ }^{47}$ Obraz i poniatie, 270. 
concrete form; everything sensory is shown not through itself, but through the expression of its meaning. And all this is due to the historical distinctiveness of the Greek poetic image. ${ }^{48}$

Image and Concept deals with the fundamental components of archaic aesthetic consciousness, and therefore Freidenberg's reconstruction of the archaic world-picture does not yet include Plato's definition of true reality in his Seventh Letter: "For everything that exists there are three classes of objects throughout which the knowledge about it must come; the knowledge itself is a fourth, and we must put as a fifth entity the actual knowledge of the object which is the true reality. We have then; first, a name, second, a description, third, an image, and fourth, a knowledge of the object." Yet "these four do as much to illustrate the particular quality of any object as they do to illustrate its essential reality because of the inadequacy of language."

Freidenberg, who traced the development of poetic ideas through the history of collective worldviews, had implicitly chosen Plato's formulation as a point of destination for the edifice of her mythological semantics.

\footnotetext{
48 Ibid., 602, 605, 610.

49 Plato, "Seventh Letter," $341 \mathrm{a}-43$.
} 


\section{A Reassessment of Freidenberg's Theories}

My life closed twice before its close;

It yet remains to see

If Immortality unveil

A third event to me

Emily Dickinson 
Chapter 12

\section{Freidenberg's Semantics and the Structural Approaches to Culture}

\section{A. Semantic Paleontology and the Semiotics of Culture}

I

$\mathrm{n}$ retrospect, it seems possible to explain in quite precise terms the significance of restoring Freidenberg's semantic paleontology to contemporary semiotic studies and structural approaches to culture. As an original theorist, she felt confident about the validity of her methods, but as an individual scholar, she was frustrated by the lack of support for her innovative ideas. With her own unique blend of humorous and sarcastic expressions, Freidenberg observed that instead of her colleagues from IRK and IIaM, it was "people from the cinema" who were finding creative inspiration in her writings. So much so that one film director, her "old peer" (staryi sotovarishch), invited her to co-author a film scenario. "The film directors were well-educated people, they knew all of our [her and Frank-Kamenetskii's-N. P.] works, for which they were later persecuted by Stalin" (5: 94). ${ }^{1}$

As demonstrated earlier, the appearance of the subject/object dichotomy signals the ultimate boundary in Freidenberg's semantics. Her analysis does not enter into the world of the individual's reciprocal relations with society and its structures. Freidenberg reserves for herself one specific sphere, that of primeval and ancient cultures, cultural restorations of rituals, and the mythological and folkloric concepts which con-

${ }^{1}$ During 1925-36, Boris Eikhenbaum, Ieremiia Ioffe, and two classicists, Lev Trauberg and Adrian Piotrovskii, expressed interest in the theory and practice of cinema and were affiliated with both Leningrad University and the Institute of the History of Arts (Gosudarstvennyi institut istorii iskusstv, GIII). For a detailed discussion of their views, see Stella Gurevich, Leningradskoe kinovedenie: Zubovskii osobniak 1925-1936 (St. Petersburg: Rossiiskii institut istorii iskusstv, 1998), 114-15, 116-35. I thank Professor Viacheslav Vsevolodovich Ivanov, who informed me that Sergei Eisenstein left marginalia on the works of Freidenberg which he had in his library. 
stitute the integral collective image of time, space, and ethos. She carefully protects her writings from psychologically marked, romantic, or modern terminology. For instance, she uses the expression "a duplicate figure" (dublikat) rather than "the double" (dvoinik), and, in her analysis of Greek tragedy, insists that a phantom Helen in Euripides, or two sisters named Bacchis in Plautus have nothing to do with the psychology of the double. According to Freidenberg, in Helen, through the illusional scene that takes place at the gate to the tomb of Proteus, Euripides reinvoked the epic Hubris/Dike formula of Homer; and in Bacchides, with the depiction of the comic inversion of social morals, Plautus produced a palimpsest upon the Trojan epics. The farcical plot of this comedy, which is performed by nine actors, includes four sets of paired personages and a protagonist of the action. Paired personages are shown as duplicate figures: two courtesan twin sisters, two young men, two old fathers, and two servants, while the protagonist of the action, Chrysalus, is the slave of two masters-father and son. Neither member of these pairs, Freidenberg demonstrated, is meant to be a "Döppelganger," a psychological inversion of the other. As the plot develops, the farce deviates from the illusory identity of paired characters, and the comedy of errors addresses epic forms: at once the Iliad and the Odyssey. In Bacchides, one of the two fathers is linked to Priam and besieged Troy, and "Chrysalus is cast as the Greeks-Ulysses, Agamemnon, Menelaus, Ajax, and Achilles rolled into one."

The unwillingness to discuss the impact of another individual upon the cognizant subjectum can be seen clearly in Freidenberg's culturological writings where she studies rituals of consecrated foolery and demonstrates that the opposite image-concepts-the consecrated person and the buffoon (god, king, master vs. slave, servant)-originated in a common semantic cluster. The master/servant figures were understood as functional substitutes for each other, and this identity of opposite characteristics brought about the semantics of the holy redeemer. ${ }^{3}$ Freidenberg, however, does not extend her semantic analysis of "the other" as the "substitute figure" to the territories of "I" and "Thou" dialogical relations. She does not draw into the discussion a complex cluster of the ruler/slave antinomies that provided invariants to the figures of religious pretender, royal impostor, and/or political usurper, and she does not explain cultural mechanisms of these phenomena in history. Rather the question is whether her results have been surpassed or rendered obsolete by contemporary scholars who approach the

${ }^{2}$ Cf. O. Freidenberg, "Palliata," Mif $i$ teatr, 38-41, and James Tatum, introduction and commentary to The Darker Comedies, by Plautus (Baltimore and London: The Johns Hopkins University Press, 1983), 18-19, 31, 64-65, 80-81.

${ }^{3}$ Freidenberg, "Makkus i Maria," 3-20. 
subject/object dichotomy and the role of dual models in the dynamics of culture from the position of cultural semiotics.

Many of the Marrist scholars were familiar with Saussure's Semiology and Charles Pierce's Semiotics. ${ }^{4}$ For Freidenberg, the study of prelogical thinking was directly related to her understanding of collective consciousness as a system of representations and signs. Viacheslav Vs. Ivanov, Eleazar Meletinskii, and Iurii Lotman all acknowledged that her contributions to culturology anticipated the development of cultural semiotics. However, they specifically emphasized that her unconditional resistance to personalistic approaches made it impossible for her to develop an adequate apparatus to describe an actual rather than a hypothetical relationship between man and the collective and to interpret the root-causes of individual phenomena and their specific nature. ${ }^{5}$ According to Lotman, Freidenberg's attempt to concentrate attention on cultural and mythological semantics and to reconstruct "the universal structure of the archaic consciousness" had "entailed loss of comprehension of the structural unity" of the individual phenomena and brought about reductionism as an inevitable consequence. ${ }^{6} \mathrm{~F}$ or Lotman, therein lay the main contradiction of Freidenberg's genetic method.

This peculiar reductionism of a well-grounded system of knowledge can be treated as "the other side of the coin" in semantic paleontology, for, as a culturological approach, it provides a contrastive background for a firmer understanding of the consciously chosen actions an individual person may perform in various liminal situations in the society.

In the 1920s and mid-1930s Freidenberg's goal, as she formulated it, was to trace the polysemy of the same semantic compounds through the verbal art and historical poetics of the preliterate period. She traced the inter- and intrageneric transformations of archetypal antinomic identities not only in her Poetics of Plot and Genre, but also in the paper

\footnotetext{
${ }^{4}$ Viach. Vs. Ivanov, Ocherki po istorii semiotiki $v$ SSSR (Moscow: Nauka, 1976), 15-19 (references are to N. Ia. Marr, I. Meshchaninov, N. F. Iakovlev), 34-36 (references are to Freidenberg's writings of 1932-36 and to "Lectures on the Theory of Ancient Folklore").

${ }^{5}$ For an acknowledgment of Freidenberg's ideas in the semiotics of culture, see, for instance, E. M. Meletinskii, "Istoricheskaia poetika A. N. Veselovskogo i problemy proiskhozhdeniia povestvovatel'noi literatury," Istoricheskaia poetika: Itogi i perspektivy izucheniia (Moscow: Nauka, 1986), 30-37. For Meletinskii's reservations about the reductionism of paleontological approaches, see his Vvedenie $v$ istoricheskuiu poetiku eposa i romana (Moscow: Nauka, 1986), 8-9.

6 Ju. M. Lotman, "O. M. Freidenberg as a Student of Culture," in Semiotics and Structuralism: Readings from the Soviet Union, ed. Henryk Baran (White Plains, NY: International Arts and Science Press, 1976), 260.
} 
"From Pre-Homeric Semantics."7 Here, using paleontological methods, she reconstructed clusters of obliterated semantic meanings in the word "friend" (drug) and traced their modifications through the various discourse styles of different cultural stages. Her study addressed wide cultural and historical contexts. Initially the utterance "friend" (etairoz, Greek), Freidenberg said, was bivalent and included the unity of two poles: (a) one's self and someone else; and (b) another person-one's friend (drugoi-drug). The first semantic matrix can be traced in various mythological plots and archaic cultural survivals, where it is expressed as the unity of two men dedicated to one another in life and death (a vestige of the mythological metaphor of the life/death unity). Ambivalent life-death and love-hate compounds can be detected in all of these plots. The second semantic matrix generates various combinations of meanings and plots that represent the destiny of another person-he who fights together with a friend, on behalf of him, or instead of him, in the name of a friend, patron, ruler, king, or God: he who substitutes for one's person in various situations; a friend is seen as a substitute figure, as "another." At this stage, new plots originate from the old semantic units and produce new genre constructions by disentangling old metaphors.

Freidenberg writes in "From Pre-Homeric Semantics" that a remarkable derivative of the "friend-another person" antinomic identity can be found in ancient rituals of the crowning and dethroning of the false ruler. These solemn, yet carnivalized game rituals were performed to protect the collective-the whole country and its ruler-from massacre, from famine, from the loss of the king. In these rituals the ruler's slave was dressed in the king's garments, provided with all the emblems and regalia of supreme power, led to the throne, and brought into the king's bedchamber. Then the false ruler was dislodged, disrobed, whipped, and beheaded. Freidenberg underscores the survivals of bivalent unities: life-death, heroic-chthonic, and sacred-profane in the semantics and architectonics of this ritual performance. She concludes that the "law of magic participation," the principle of "pars pro toto," and the indeterminacy of subject-object relations structured the ritual performance, where the slave of a royal person was made into a truly royal slave.

Freidenberg also discussed a peculiar detail of burial rites. In the Iliad, Achilles throws two dogs into the funeral fire as a sacrificial offering for his friend Patroclus. The "sacrificial dogs" were raised in Achilles's palace; they have always followed their master, slept in his bedroom, and eaten from his plates during feasts. In other words, the dogs who used to be like human friends to Achilles are chosen instead of

${ }^{7}$ Freidenberg, "Iz do-gomerovskoi semantiki," 381-392. 
him to follow his real friend Patroclus into the kingdom of death. The two dogs metaphorically represent Cerberus, the watchdog and twoheaded chthonic monster who guards the entrance to the underworld. ${ }^{8}$ Thus, the mythopoetic fabric of the Iliad adopts and reconstitutes the semantics of all the previous archaic unities: the unity of life and death, of two people, of a friend as other person or as a substitute figure.

Ancient rulers used to maintain a retinue of table companions that included spongers or parasites. While parasites were allowed into the patron's feast rooms, where they shared his meals, they were, nevertheless, fed like dogs on leftovers, groveling and crouching at their master's knees. Like dogs, the parasites were not permitted to raise their heads and look into the eyes of the master (thus the connotation of the underworld and survivals of chthonic imagery are preserved at a higher cultural stage, within a different genre formation). The lives of these parasites were easily sacrificed for the sake of the ruler's health and protection. Hence, within the semantic cluster, watch-man and watch-dog were equivalent components. Metaphorically, one substituted for the other in ritual performances and in the archaic genres of the verbal arts. While preserving their contents, the same semantic compounds were reshaped uniquely within different categories of a people's collective experience.

Freidenberg's analysis of ancient burial rites investigates the semantics of cultural forms. The substitution of the "sacrificial dogs" for human lives had brought about a new stage of development in human communities. Primordial totemism had lost its materiality, and its concreteness found its reflection in the different overall structures of all those plots that were wholly dependent on the language of metaphors, which now provided interpretations of concrete images as abstractions. Paleontological explorations of pre-Homeric semantics which Freidenberg undertook in this paper and further developed in The Poetics of Plot and Genre, demonstrate how different figures appear to fulfill the function of the same motif which is, itself, now understood metaphorically, as a symbolic representation of the archetypal image.

Freidenberg's discussion of the non-differentiated relation between subject ("I") and object ("he") as they were represented by the semantic cluster drug-drugoi offers a guiding thread through the maze of such political, religious, and religiously subversive events in history as royal

${ }^{8}$ On the perceptual level, Freidenberg's fragment "Friend-Another One" ("Drug-Drugoi") has direct analogies to pictorial and figurative images in Sergei Eisenstein's movie Ivan The Terrible (Maliuta Skuratov crouching at Ivan's knees in the pose of the watchdog, the wild dance of the Oprichniks with the dog masks on their faces, and chthonic images of fire and destruction, to name a few). 
imposture; the opposition "tsar and pretender"; the reign of Ivan the Terrible and the following interregnum known in Russian history as "the Time of Troubles," as well as the development and wide circulation of utopian legends of "royal redeemers" and fabulous kingdoms of unknown location (such as the White Water Land and the New Isles). ${ }^{9}$

Looking into the various practices, rituals, and quasi-theatrical performances that Ivan the Terrible invented as emblems of his unrestrained power, one can see that these activities spurred numerous attempts at royal imposture and catalyzed the development and wide circulation of utopian legends about the Tsar-Deliverer. Samozvanchestvo, or royal imposture, has been discussed by Boris Uspenskii who also refers to a peculiar "game of Tsar" which was played in Muscovy. Uspenskii claims that this "game' "could be played not by pretenders, but by real Tsars who forced another man to be the false, inauthentic Tsar-a Tsar in outward appearance only." 10 Uspenskii's examples (Ivan the Terrible and his retribution against his equerry, Ivan Petrovich Fedorov-Cheliadin and against the grandson of the Tatar Khan Akhmat, Simeon Bekbulatovich) provide a direct analogy to those examples found in Freidenberg's "From Pre-Homeric Semantics." The analogy is even closer since Ivan's rationale and the ambivalent justification of his actions in this "ritual game" can be interpreted from the position of cultural anthropology. In this framework, the "ritual game" provides an example of the "deception by substitution" function, well known to folklore scholars. ${ }^{11}$

${ }^{9}$ For Freidenberg, see also lectures 5 and 6 in "Prolegomenon to the Theory of Ancient Folklore," $M L, 36-47$. For the perceptual plane of self-other relations as it was seen through the image structure of "the utopian legends of the Tsardeliverer," see K. V. Chistov, Russkie narodnye sotsial'no-utopicheskie legendy $X V I I-X I X v v$. (Moscow: Nauka, 1967). Part 1 examines folk legends of "royal redeemers"; part 2 offers a discussion of different utopian egalitarian communities located along the shores of Rivers Dar'ia and Anapa, and the dwellings of the righteous, such as the White Water Land (Belovod'e), the city of Ignata (gorod Ignata), the New Isles (Novye Ostrova), and the Hazelnut Land (Orekhovaia zemlia). In his excellent study, Chistov, who by the late 1950s had become acknowledged as a prominent Soviet folklorist, does not mention Freidenberg.

10 B. A. Uspenskii, "Tsar and Pretender: Samozvanchestvo or Royal Imposture in Russia as a Cultural-Historical Phenomenon," in Ju. M. Lotman, B. A. Uspensky, The Semiotics of Russian Culture. Michigan Slavic Contributions 11 (1984): 26870.

11 Cf., for instance, James George Frazer's discussion of "substitutes, put to death instead of kings." The Golden Bough (New York: Macmillan, 1960), 324, $328,337$. 
The perception of the "protective magic" game as a carefully thought out strategy is identical to the phenomena Freidenberg discovered in archaic folklore and interpreted in her fragment "FriendAnother Person" ("Drug-Drugoi") in "From Pre-Homeric Semantics." To use Freidenberg's terminology, in both ritual performances Ivan the Terrible found "a duplicate of his own image" in the figure of a slaveenemy. Whether with good reason or on no grounds whatsoever, he nevertheless believed that his vassal liegeman Fedorov-Cheliadin was secretly plotting against him, and that Simeon Bekbulatovich, his vassal of royal lineage, sought to oust him from the throne. Rather than threatening Ivan's own life, both "enemies" were dangerous to the entire country and to its ruler. Ivan thus fabricated a situation whose "salutary" resolution required a sacrificial offering on behalf of himthe ruler whose life symbolized the commonwealth of his subjects and of the whole country. Another person (drugoi), a human being whose life was used as an object of sacrificial offering, was decorated for the sacrifice and made into the living effigy of the tsar. While not being Pretenders, Fedorov-Cheliadin and Simeon Bekbulatovich, living effigies of the true tsar, were forced to substitute for the anointed king and perform the roles of royal impostors.

A close connection between samozvanchestvo and Christian and profane utopian legends of redeemers has been traced by K. V. Chistov, who considered royal imposture "as a realization of the legend" of the Tsar-Deliverer. ${ }^{12}$ The etiology and the structure of Russian Christian and profane legends of royal deliverers and redeemers and of the blissful kingdoms of unknown location can be traced to their mythological archetypes, and their morphology is known from the myths of the passions, death, and resurrection of proto-Dionysian gods. More than forty years prior to Chistov, Freidenberg discussed the constituent morphologic features of similar, yet sparser sources: suffice it to refer to her master's thesis "The Origin of the Greek Novel," to the already mentioned "From Pre-Homeric Semantics" and to "On the Semantics of the Folklore Proper Names: Makkus and Maria."13 It will be interesting, therefore, to reintroduce her conclusions to contemporary culturology and to treat her ideas and Chistov's observations as mutually complementary views.

According to Chistov, the general model for the plot on the recurrent return of the royal Deliverer (Redeemer) is built by several stable morphological functions:

12 Chistov, Sotsialno-utopicheskie legendy, 174-186; Uspensky, "Tsar and Pretender," 259.

${ }^{13}$ Freidenberg, "Makkus i Maria," 3-4, 13-16, 18-20. 
A. A Deliverer (the young tsar or a prince) aims to change his people's life.

B. His enemies (a retinue or the boyars) attempt to dethrone him and to get rid of him (to kill and "entomb" him in the grave, in a prison or monastic cell).

C. The royal Deliverer is miraculously saved, for another human, a living thing or an inanimate object (a friend, a dog, a wooden effigy) substitutes for him and dies in his stead.

D. The royal Deliverer escapes, changes his identity, hides (in the cave, in the mountains) or travels to distant places (to far-away countries).

E. His countrymen or messengers from his kingdom meet and identify the Deliverer, who sends with them a conduct to his people.

F. A false ruler who had usurped the throne tries to kill the royal Deliverer, and the Deliverer's enemies continue to persecute him.

G. The royal Deliverer returns to his country (ahead of the promised day, following an appointed sign).

$\mathrm{H}$. He is identified by some hidden marks on his body and brought back to the throne.

I-K. As a fair ruler the Deliverer brings peace, happiness, and wealth to his people. ${ }^{14}$

Unbeknownst to himself, Chistov, with his morphological study of the plot of the recurrent return of the royal Deliverer, repeats Freidenberg's model for reconstitution of plot-genre correlations in pagan myths of the eternal return and in early Christian apocrypha. Like Freidenberg, who recognizes in the morphology of the apocryphal Acts of Paul and Thecla several characteristic traits of ancient novel, Chistov notices that the utopian legends of royal Deliverers incorporate components of plot structures which later will characterize the main plot-lines of adventure novels. To use Freidenberg's language, the position of the hero in these legends "meets all expectations of the not yet shaped genre."15

In her master's thesis and in the works written in the mid-1930s, Freidenberg offers a more effective, precise, and resilient model for genre transformations than Chistov. Further readings of Chistov within the framework of Freidenberg's interpretations demonstrate that, although utopian legends of royal Deliverers are all built according to the same pattern, each miraculous redeemer is viewed as a unique personality. The genre of the legends, however, assigns these individual qualities a conceptual interpretation that originated not in history, but in the

${ }^{14}$ Chistov, Sotsialno-utopicheskie legendy, 30-32.

${ }^{15}$ Freidenberg, "Proiskhozhdenie grecheskogo romana," 43. 
Scriptures. ${ }^{16}$ Similarly, motifs of social and "political" expectations in the plots of Chistov's utopian legends all originate in the redemptive teachings of apocrypha and pseudepigrapha. The restoration of paleontological methods to social and historical studies enables one to uncover the cultural mechanisms which charged various folklore discourse genres with the validity of the ideological conception. One can fairly conclude that semantic paleontology of culture and structural approaches to meanings use similar generative models.

To trace affinities between semantic paleontology and contemporary cultural studies beyond the generative models, a significant reassessment of Freidenberg's cultural views is required, for she never discussed the specific nature of any of the above-mentioned cultural phenomena. The unwillingness to step into the sphere of an individual's creative thought and activities can be seen clearly in her scholarship, and one should not be surprised therefore, that neither Chistov, nor Uspenskii make use of her methodologies even when they describe historical events whose structure and composition are very close to Freidenberg's interpretation of true/false and "drug-drugoi" antinomic identities in archaic cultures.

\section{B. Two Scenarios of Christ's Entry into Jerusalem}

As a culturological approach, Freidenberg's semantic paleontology is a valuable counterpart to semiotic studies, for it offers an original understanding of the social and ideological aspects of various liminal processes in different cultures. To draw further illustrations of inter- and intrageneric transformations of the same archetypal model, one can suggest a comparative interpretation of ecclesiastic and court ceremonies that Ivan the Terrible introduced to Epiphany Day and Palm Sunday. Authentic descriptions of both ceremonies were recorded in 1527 and 1558 , and the iconology of the rituals, their political, royal secular, and spiritual symbolism have been analyzed by Paul Bushkovitch and Michael Flier. ${ }^{17}$ Freidenberg's treatment of plot-genre and image-con-

${ }^{16}$ Cf. Freidenberg's discussion of "the compositional formants" and "morphemes which transcribe the conceptual meaning of the tales" in chap. 2.

17 Paul A. Bushkovitch, "The Epiphany Ceremony of the Russian Court in the Sixteenth and Seventeenth Centuries," The Russian Review 49: 1 (1990): 1-17; Michael S. Flier, "The Iconography of Royal Procession: Ivan the Terrible and the Muscovite Palm Sunday Ritual," in European Monarchy: Its Evolution and Practice from Roman Antiquity to Modern Times, ed. Heinz Duchhardt (Stuttgart: Franz Steiner, 1992), 109-125; Michael S. Flier, "The Iconology of Royal Ritual in Sixteenth-Century Muscovy," in Byzantine Studies: Essays on the Slavic World and the Eleventh Century, ed. Speros Vryonis et al. (New Rochelle, NY: Aristide D. Caratzas, Publisher, 1992), 53-76. 
cept relations as they are known from her "Entry into Jerusalem upon an Ass" provides a complementary counterpart to the above mentioned studies. $^{18}$

The Epiphany ceremony, in which the tsar and the metropolitan were the main participants, began with a procession moving from the cathedral to a special square ice-hole on the Moscow river. "There was the scaffold of boards made, upon which stood a faire chair in which Metropolitan was set, but the Emperor's majesty stood upon the ice."19 The metropolitan sanctified the water and gave blessing to the tsar. The Palm Sunday ritual, introduced to Moscow in 1547, after Ivan was crowned as tsar, also involved the metropolitan among its main participants. The Palm Sunday procession started at the Cathedral of the Dormition, moved around the Kremlin, and returned to the Cathedral for the end of the service. Upon a horse whose ears "were made long like to an asses' ears, the Metropolitan was sitteth sidelong like a woman: in his lappe lieth a faire booke [the Gospels], with a crucifix ... which he holdeth fast with his left hand, and in his right hand he hath a crosse of gold, with which crosse he ceaseth not to blesse the people as he rideth." ${ }^{20}$ One of the tsar's noblemen led the horse by the head, while the tsar himself holding a palm branch in his right hand, walked by the horse's left side and led it by the bridle.

The pageant provided a reenactment of Christ's entry into Jerusalem, but as a cultural text it drew its symbolism from different spheres of communal experiences. As Bushkovitch believes, both rituals emphasized the supremacy of the spiritual authority of the Church. ${ }^{21}$ Flier argues that the symbolism of both rituals sought to locate the especially important holy days from the ecclesiastic calendar (Epiphany day, January 6, and Palm Sunday) within the framework of universal history. In both ceremonies a "purposeful inequality" of positions allocated to the metropolitan and the tsar provided "a regulated context in which the tsar's topos of humility is to be performed as a pious deed." 2 In Ivan's recast "Entry into the Town upon an Ass," biblical symbolism was preserved up to the minutest details (such as the white cloth covering the horse, the bridle, and the palm branch), yet the details were

\footnotetext{
18 Freidenberg, "V"ezd v Ierusalim," 623-65.

19 Bushkovitch's reference is to the records of Anthony Jenkinson, the English envoy to Russia in 1558. Bushkovitch, "Epiphany Ceremony of the Russian Court," 7. See also Flier, "Iconology of Royal Ritual," 53, 74-75 n.

20 Flier, "Iconography of Royal Procession," 109.

21 Bushkovitch, "Epiphany Ceremony of the Russian Court," 1-2, 15.

22 Flier, "Iconography of Royal Procession," 117-18.
} 
selected and recombined in agreement with his own idea of "imperial humility."23

As Freidenberg would have argued, supporting Flier's interpretation, in Ivan's new ecclesiastic performance, every visible object functioned as a concept and represented something far larger than its nominal meaning. The participants in the processions were not envisioned as individuals; they all represented ideas and polyvalent concepts. In her study "Entry into Jerusalem upon an Ass" Freidenberg singled out certain biblical episodes and images with latent symbolic meaning and then restored to them the connotations of salvation, redemption, the patriarchs' authority, and the kings'/tsars' power. ${ }^{24}$ She reconstructed the obliterated pagan connotations of salvation which were related to the image of an ass in ancient Greek and Egyptian mythologies and recombined them with the Judeo-Christian interpretation of the Savior.

If considered from Freidenberg's point-of-view, the "entry" ceremonies would enhance the transference of semantic values and single out the moments in the development of communal consciousness whereby ecclesiastic and theological symbols became components of a secularized political, yet still spiritual worldview. When applied to the context of the semiotics of Russian culture, Freidenberg's semantic reconstitutions corroborate Flier's conclusions that through religious ceremonies Ivan the Terrible recast biblical symbolism into new emblems of autocratic power. All the pictorial, visible images of Ivan's pageant were charged with a new conceptual meaning. From the position of Freidenberg's theories, one can readily characterize Ivan's new scenario of "Entering the Town upon an Ass" as narration, in contrast to merely an old "spectacle" whose very essence was in imitation of what once had happened at the gates of Jerusalem. In Ivan's Palm Sunday ritual and in his Epiphany ritual one can clearly see the prevalence of conceptual symbols over pictorial images. All the paraphernalia of the pageant form a semantic cluster that reenhances the spiritual metaphor central to the Old and New Testaments: "Tell ye the daughter of Zion, Behold, thy King cometh unto thee, meek and riding upon a colt of an ass." (Matt 21: 5; Isa 62:11).

\section{${ }^{23}$ Ibid., 124.}

${ }^{24}$ Freidenberg, "V"ezd v Ierusalim," 627-32, 652-54. Since in the Slavonic translation "king" is rendered as "tsar," the symbolic and conceptual identification of the Muscovite tsar with the leader of Orthodox Christianity found its expression in the grammatical forms of the Russian language and in Ivan's reemphasized discourse of the Palm Sunday ritual. Similarly, the metropolitan's posture at the horse's back alluded to the theological concept of the Church (tserkov', feminine in Russian)-the celestial bride of Christ. 
The traditional ecclesiastic pageant reenacted an episode (a picture) from Christ's life. Its perceptual and conceptual planes were both limited to "how it happened." In contrast, Ivan's recast reproduction of an old spectacle rendered a picture as a "narration created by conceptual thought," and the concreteness of archaic images took on abstract features in his ceremonies. According to Freidenberg, "a picture cannot render expressions like 'if', 'when', 'in order to', "because of', and so on." Conversely, narration which is brought about by conceptual thought can pass on to this religious spectacle the general notion of the great task which a person aims to accomplish. Narration specifies causes and conditions "which move the plot along and fill it with relations to real processes; it brings about dependence and leads to certain results." ${ }^{25}$

${ }^{25}$ Freidenberg, "Proiskhozhdenie narratsii," $M L, 226$. 
Chapter 13

The Freidenberg-Bakhtin Correlation

\section{A. Freidenberg and Bakhtin on the Role of an Individual in the Social World}

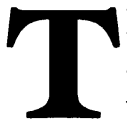
he Freidenberg-Bakhtin correlation could easily be the subject of a special study, although the two scholars never met. Freidenberg was uninformed of Bakhtin's Problems of Dostoevsky's Creative Works, which appeared in 1929, she expressed no interest in the writings of the Bakhtin circle, and of the entire group, she was vaguely familiar only with Voloshinov, of whom she held a very unflattering opinion (4: 226). ${ }^{1}$ As for Bakhtin, he was well familiar with the Poetics of Plot and Genre. When he began working on what later became his book on Rabelais, he took down a detailed synopsis of the central part of Freidenberg's study-part 2-which deals specifically with the preliterate period of plot and genre. ${ }^{2}$ Bakhtin filled three school notebooks with his excerpts from Freidenberg, and on the margins of his manuscript he placed numerous self-addressed notes. For instance, while referring to Freidenberg's description of skolion (Greek drinking song sung successively by the participants in the banquet), Bakhtin added a note: "See Issoudun in Rabelais," and in the definitive text of his book he elaborated this cryptic note in a detailed description of banquet images in Rabelais. ${ }^{3}$ Other marginalia addressed Freidenberg's discussion of the birth-death-resurrection cycle and her treatment of the metaphors of eating (killing/sacrificing the victim, consuming its flesh, gaining life potency, and procreating). Most likely, Bakhtin borrowed Freidenberg's book from one of his friends and was working on it while

\footnotetext{
1 Perlina, "Funny Things are Happening," 25-26.

${ }^{2}$ I am grateful to Sergei Georgievich Bocharov and other editors of the Complete Works of M. M. Bakhtin who made me familiar with his synopsis of Freidenberg's writings.

${ }^{3}$ Cf.: Freidenberg, Poetika siuzheta i zhanra, 42, Bakhtin's notebook 1, p. 3, and Mikhail Bakhtin, Rabelais and his World, trans. Helene Iswolsky (Bloomington: Indiana University Press, 1984), 286-89.
} 
staying in the small town of Savelovo, near Moscow, in late 1937-early 1938. ${ }^{4}$ As his health condition worsened, in February 1938, he was hospitalized for the amputation of his right leg. In all probability, before the operation he returned Freidenberg's book to its owner without having finished his synopsis. In his book on Rabelais, however, he limited his observations on Freidenberg's scholarship to one single footnote. While appreciating Freidenberg's analysis of the archaic popular culture of laughter as the most meritorious aspect of The Poetics of Plot and Genre, he implied that Freidenberg's adherence to the theory of prelogical thought made her study of little relevance to his own treatment of the problem. ${ }^{5}$

Accepting this notion seriously, I have suggested elsewhere that the two scholars worked out quite different aesthetic theories that badly needed each other as complementary counterparts, but never converged. ${ }^{6}$ To fuse Bakhtin's culturological ideas with those of Freidenberg within one theoretical framework would hardly be possible, for rather than interpretations, the grounds for the interpretative strategies were not at all similar in their respective studies. Proceeding from different phenomenological positions, the scholars envisioned the temporo-spatial universe and the role of the individual in the social world as the protagonists of two different "chronotopes." 7 Thus the FreidenbergBakhtin opposition raises a question of whether one chronotope lends itself to translation into another, and whether the translation would work in both directions.

To answer this question, it is essentially necessary to understand the difference between the dichotomies "I-the other I" and "self-other." In the drafts to his major unfinished study Art and Answerability, Bakhtin discussed the "I-the other I" problem, whereas the majority of contemporary scholars (including Freidenberg) operated with the category of "one's self."

\footnotetext{
${ }^{4}$ I have grounded my chronological attribution on the typographical marks on the notebooks' covers, of which two are dated 1937, and one 1938.

5 Bakhtin, Rabelais and his World, 54.

${ }^{6}$ Perlina, "From Historical Semantics," 17-18. For the discussion of the epistemology of the human self and the differences between the dichotomies "I-the other I" and "Self-Other" in Bakhtin and Freidenberg, see also my paper "The Freidenberg-Bakhtin Correlation," Elementa: Journal of Slavic Studies and Comparative Cultural Semiotics 4: 1 (1998): 2-5.
}

${ }^{7}$ M. M. Bakhtin, "Forms of Time and Chronotope in the Novel," The Dialogic Imagination, trans. Caryl Emerson, ed. Michael Holquist (Austin: University of Texas Press, 1981), 84-258.

${ }^{8}$ M. M. Bakhtin, Art and Answerability: Early Philosophical Essays, trans. Vadim Liapunov, ed. Michael Holquist and Vadim Liapunov (Austin: University 
being, and for that reason makes "my own self" comparable to "the self of another" person. Bakhtin, conversely, brings to the fore the "everpresent excess of $m y$ seeing, knowing, and possessing in relation to any other human being." This concrete outsideness (vnenakhodimost') of me myself and the outsideness-for-me of all other human beings is the category that "provides the foundation for a certain sphere of my own exclusive self-activity, i.e., all those inner and outer actions which only I can perform in relation to the other, and which are completely inaccessible to the other himself from his own place outside of me."10 Within this framework, all of my behavioral manifestations and actions-aesthetic activity, creating a hero, establishing an ethical, aesthetic, contemplative relation to the other-no matter how different they are thematically, can be characterized by "the excess of my seeing" and "filling in" the horizon of another human being. Although "the composition of this excess tends toward a certain stable constancy," empathizing or projecting one's own self into the self of the other is impossible due to the "concrete uniqueness of the place in being that is occupied by the subjectum of ... action." 11 Both the subjectum and the aesthetic object have a distinctive personalistic character, according to Bakhtin.

Freidenberg maps out her epistemology of the human self within the territories of preliterate oral cultures and ancient literatures. Therefore there is no need to argue that she operates with different stages of social development and with different cognitive structures in human culture. Yet rather than the "historical stage and structure" of cultural development, the understanding of the subject-object relation makes the difference between the two scholars' systems. In her "Lectures on the Theory of the Folklore of Antiquity" Freidenberg investigates the issues of cognition and of constructing universally valid images and concepts of

of Texas Press, 1990). For an explanation of Bakhtin's phenomenological position in aesthetic and literary theory, see Vadim Liapunov, "Notes," in Art and Answerability, 232-34. For an interpretation of "the active operation of the Ego" and "the self-activity for which I am individually answerable," see M. M. Bakhtin, Toward a Philosophy of the Act, trans. Vadim Liapunov, ed. Michael Holquist and Vadim Liapunov (Austin: University of Texas Press, 1993), 6, 3233, 41-49. I owe my explanation of Bakhtin's phenomenology to Liapunov's "Translator's Preface" and commentary to this work of Bakhtin (xviii-xix, 8485, 95-96). See also Liapunov's explanation that, according to Bakhtin, "the organizing center of architectonic is the given human being in his or her existence in the world," in his "Notes on Bakhtin's Terminology: Architectonic(s)," Elementa 4: 1 (1998): 69.

${ }^{9}$ Bakhtin, Art and Answerability, 23.

${ }^{10}$ Ibid., 24, 235 n. 28.

${ }^{11}$ Ibid. 
the world and suggests her method of understanding the self/other or subject/object relations. ${ }^{12}$

The foremost question is: Where did primeval man find himself, in what world, among which surroundings, and in what environment? Where and how did he create reality for himself? This is the problem of the cognized world, and of the object as the latter was conceived by the cognizant consciousness of the human subject. $^{13}$

In primeval cultures and archaic folklore, Freidenberg argues, the separation of the individual self from the tribal communal totem, the partition between my own self and everything that is "not I" can be traced through the forms of self-identification and self-addressivity. From the fact that in Latin antiquity a male person would identify his own "I" as "my genius," and a female as "my Juno," Freidenberg draws the conclusion that at this earliest stage man did not distinguish himself from the nature surrounding him. The immediate surroundings-the picture of the world-and the speculative world of concepts and generalizations were not yet distinguished as two opposite entities, and, furthermore, the cognition of one's own self-of the subject as different from any other human-was not yet formed. Working on "The Origin of the Greek Lyric" Freidenberg argues that the separation of subject from object continues over a long period of time during which both subject and object fulfill each other's function. ${ }^{14}$ Thus in Sappho's Fragment from Book Five the female poet, the speaking person, the ego who expresses the plea, wishes to be reunited with the divine order of things and reincorporated into the divine unity of earth and heaven.

\section{B. "The Birth of the Author" and "The Prehistory of Novelistic Discourse"}

In her diaries and in her scholarly writings Freidenberg emphasizes that cognition of the self and recognition of the poet's own self in lyric poetry are processes bound by time and space: "It is in lyric poetry that the universe is inhabited for the first time by people in a social world, and all functions of the elemental forces of nature are now applicable to man... The separation of subject from object represents a lengthy process; the birth of the author in the seventh century B.C. is a reflection of this process." ${ }^{15}$ Freidenberg treats the genesis of the lyrical mode, its

\footnotetext{
12 Freidenberg, $M L, 9-169$.

13 Ibid., 29.

14 Freidenberg, "Proiskhozhdenie grecheskoi liriki," 106.

15 Mossman, Correspondence, 266. Cf. also "Proiskhozhdenie grecheskoi liriki," 109-10.
} 
genres, discourse categories and "the birth" of the lyric author as an essentially new "event in life" that produced new social categories of cognition and of Weltanschauung.

This principle is fundamental to Freidenberg's explanation of the author-hero relationship, as well as to her discussion of ancient lyric authors and their poetic vision of the surrounding world. It can be treated as "the other" in relation to Bakhtin's phenomenology, whose core definition is "the event of life." Viewed from Bakhtin's perspective, Freidenberg's understanding of the poet's " $\mathrm{I}$ " would be " $a$ constituent in a work," in a lyrical discourse. However, this "I", the human element of the poet's emotional world, is not yet expressed directly; rather it is revealed through the human element of the poet's emotional world, through the simplest details of external phenomena and makes the object speak for the subject.

The mythological word-utterance (pro-logos in relation to Logos) can be best interpreted as endowing nature with meaning ("resemantizing nature," in Freidenberg's terminology). ${ }^{16}$ Hence, once again, the difference between Freidenberg and Bakhtin lies on the "anthropomorphic/personalistic" borderline, whereas the topic of discussion remains essentially the same: imbuing nature with human features. The primeval "Logos speaks through trees, through earth and water, through birds, animals, people, and things. Forms of this discourse are agonistic. The dying cosmos is the defeated anti-totem, and cosmos revivified is the totem." In Freidenberg's terminology of antinomic identities, agon, the combat of the protagonists' discourses, brings about antiphony, dialogue, stichomythia (dialogue in single alternate lines in ancient tragedy), as well as dialogically structured riddles. In all of these discourse manifestations, Freidenberg explains,

one party asks the other, that one gives an answer. One party disputes, the other postulates; one appeals, the other listens to the appeal. It is necessary for us, modern people, to understand that listening is an active performance, it is an action [aktivnoe deistvo, akt]. One party speaks out and appeals, the other listens, hearkens to, keeps silence, yet nevertheless plays a part in the actual performing act of a single combat; it co-participates in it. Rhythmically silence corresponds to the pause, and rhythm-units rest upon combinations of the sound and the pause. ${ }^{18}$

If located along the borderline separating "constituent in" from "constituent of," Freidenberg's semantics of cultural forms becomes an

\footnotetext{
${ }^{16}$ Freidenberg, Poetika siuzheta i zhanra, 53-54.

${ }^{17}$ Freidenberg, Lecture 11, ML, 57.

18 Ibid., 58.
} 
analogue to Bakhtin's philosophical anthropology. To prove the statement, it suffices to cite Bakhtin's definition of rhythm from "The Problem of Content, Material, and Form in Verbal Art":

As a form of ordering acoustical material which is empirically apprehended, heard, and cognized, rhythm is compositional. But rhythm is architectonic when it is emotionally directed, when it relates to that value of inner striving and tension which it consummates. $^{19}$

The ultimate impact of the "in/of" distinction can be felt in differentiations between meaning and understanding and cognition and awareness. When talking about an individual work of art, Freidenberg discusses its meaning, its semantics, while Bakhtin provides its individual understanding, or comprehension. "Meaning" is a variable axiological category; its proper value, however, can be fixed within a specific temporal-spatial framework (such as mythology, folklore, social history, or historical poetics). Freidenberg's "The Origin of the Epic Simile" and "The Origin of the Greek Lyric" provide examples of this semantic approach to epistemology and aesthetics. Here lyric poetry as a new mode of thinking "represents a stage in the cognitive process, a shift in the world outlook." ${ }^{20}$ Bakhtin's "understanding" is a relational, personalistic concept, and its parameters can neither be fixed from within, nor fastened from without. "The temporal and spatial articulation and disposition of the parts of a discursive whole ... reflect ... the temporal process of the progression of human thinking ... the aestheticized, rhythmic process of thinking." ${ }^{21}$ In "The Problem of Speech Genres" Bakhtin summarizes his idea of the speaker's "active, responsive attitude" toward the discourse manifestation of another person and envisions the language collective as "the plurality of speakers, and others with respect to each given speaker." 22

Both Freidenberg and Bakhtin demonstrate that new poetic genres restore the validity of cognitive experience, while charging the old concepts with "the invariable nonidentity of semantics and its morphology" (Freidenberg) and with a new "valuative axiological weightiness" (tsennostnaia vesomost'; Bakhtin). Thus, literary genres are indeed depositories of collective memory that give individual forms of perception to

\footnotetext{
${ }^{19}$ M. M. Bakhtin, "The Problem of Content, Material, and Form in Verbal Art," trans. Kenneth Bronstrom, in Art and Answerability, 270.

20 Freidenberg, "“Proiskhozhdenie grecheskoi liriki," 105.

21 Bakhtin, Art and Answerability, 210.

22 M. M. Bakhtin, Speech Genres and Other Late Essays, trans. Vern W. McGee, ed. Caryl Emerson and Michael Holquist (Austin: University of Texas Press, 1986), 68.
} 
the poet's worldview. Literary genres implement a powerful formshaping on the subject and the object; they determine the poet's vision of the universe and the forms of his discourse. But while in Freidenberg genre as an embodiment of a new figurative and conceptual thinking totally consumes the poet as an individual speaker, and the latter finds himself completely absorbed by a new speech genre, in Bakhtin the speaking individual approaches a new value-bearing weightiness of the genre as something given to him for further reaccentuation and semantic transformation. ${ }^{23}$

As demonstrated in our discussion of Image and Concept, by virtue of their unsevered connections with the concrete mythological image, new literary genres "speak otherwise" about the picture of the world and carry into effect the anticipatory potential of collective thinking. The acknowledgment of nonidentity between "being" and "imaged being" and of the anticipatory creative powers of collective experience makes Freidenberg's theory into a highly desirable complementary counterpart to Bakhtin's study of chronotope.

Freidenberg introduces historical perspective through the relation of people and their collective communicative experience to time and space, and therefore makes her theory of literary genres capable of reflecting aesthetic aspects of epistemology and ideology. While Bakhtin insists that in our time the novel is to be acknowledged as the most significant mode of artistic thinking, fundamentally different from all other poetic modes because of its distinct view of language and of the world, one can argue that this triumph of the novel's narratological practices and approaches is time-bound, for the discourse of the novel maintains a dialogic exchange with other speech genres in history. Bakhtin's chronotope individualizes the socio-historical and aesthetic features of different epochs; the chronotope highlights the specificity of time-space coordinates within different literary genres and various discourse subcategories (i.e., lyric, epic, the Greek romance, ancient biography, the adventure novel, the novel of confession, and other chronotopic units). It is here that Freidenberg's theory complements Bakhtinian interpretations. Like the old Greek novel, archaic comedy and tragedy existed in the form of genres that contained no tragic and comic elements, and through rearrangement of their constituent formants they attained their own specifically aesthetic properties. ${ }^{24}$ The chronotope provides the most specific formula for describing the author's or hero's comprehensive

${ }^{23}$ Bakhtin clarifies his idea about "the architectonic function of the axiological center constructed by a given human being within an artistic whole" by analyzing Pushkin's lyrical poem "Parting." Art and Answerability, 211.

${ }^{24} \mathrm{Cf}$. our discussion of the cognitive function of metaphor and of allegorical discourse in chaps. 8 and 11. 
pronouncements about his own "I" and about the world around him. ${ }^{25}$ Freidenberg's scholarship, beginning with her discussion of the poetics of the old Greek erotic novel and continuing with "The Origin of the Greek Lyric" and drama in Image and Concept suggests an alternative to the Bakhtinian approach. Charging the old components of mythological plots with the validity of new genres, of new ways of perceiving the world, that is, reconstituting old narrative structures into ideologically different unities, "The Genesis of the Greek Novel" (or, as another title states, "The Greek Novel as Acts and Passions") renders the destinies of non-mythological loving couples as fairy legends of revelations, trials, passions, spiritual transfiguration, and further on-as miracles manifested through the acts and deeds of the chosen holy ones. Freidenberg's study makes one think of the general layout Bakhtin had suggested for historical poetics. It is worthwhile in this connection to accept with all seriousness the perspective which he suggested in Problems of Dostoevsky's Poetics:

The basic narrative genres of ancient Christian literature"Gospels," "Acts of the Apostles," "Apocalypse," and "Lives of the Saints and Martyrs"-are linked with an ancient aretalogy. ${ }^{26}$

All of these avenues, pointed out in passing by Bakhtin (who advances to the fore and analyses only the menippea), were carefully walked through in "The Genesis of the Greek Novel." The double title of this work spoke for itself: while the form of the Greek novel revealed features that later became recognized as definitive characteristics of Christian hagiography, the plot lines of Christian apocrypha were comparable to the plot structure of the ancient Greek romance. It is critical to our discussion that we take note of the general composite schemata of plot in both romance and apocrypha; the heroes' behavior, their adventures and ordeals, as well as the stable, distinctive features of the heroes are remarkably similar to what we know as the constituents of the Bakhtinian chronotope of the Greek romance. ${ }^{27}$

Freidenberg's definition "the novel as Acts and Passions," as well as the title of her paper "The Gospel-One Type of Greek Novel,"28 emphasize intergeneric relations in the treatment of cultural ideas and

\footnotetext{
${ }^{25}$ For a thorough discussion of the problem, see Perlina, "Erich Auerbach and Mikhail Bakhtin on the Aesthetic Representation of Reality," trans. as "Auerbach e Bachtin sulla rappresentazioni artistica della realta," L'immagine riflessa 1-2 (1984): 233-55.

${ }^{26}$ Bakhtin, Problems of Dostoevsky's Poetics, 135.

27 For the typical schema for the ancient romance, see Bakhtin, "Forms of Time and Chronotope in the Novel," 87-88, 94.

${ }^{28}$ Freidenberg, "Evangelie," 29-47.
} 
cognitive concepts. She also deals with other (characteristically Bakhtinian) problems from the "prehistory of novelistic discourse." Discussing the cultural semantics and prehistory of sainthood, she demonstrates that the emotive and thematic compounds of the concept of the female saint originate in the religious prototype of the hierodule, "the handmaid of God."

Using religious apocrypha, the genre that occupied the boundary territory between oral and written cultures, Freidenberg demonstrates that the authors of the stories about the ordeals and acts of the heroes who later became canonized as Christian saints were compelled to compose their tales in agreement with the already acknowledged, authoritative emotional experience of their listeners/readers. Yet the stories they composed addressed new problems and thus they endeavored to envision new types of human personalities. In this sense, Freidenberg emphasizes, "the early Christian era found all the preconditions it sought in the elements of the Greek novel." 29

Having chosen three strikingly dissimilar types of narrativelegends about cosmic elements in proto-historic society, the ancient Greek romance, and early Christian apocrypha-Freidenberg argued that the transference of semantics from one anthropomorphic stage to the other, the radical changes in the images of the cosmos, time, and life, found its reflection in the recasting of the semantic functions of plot and genre in the history of narratology. She explained how the semantics of the old pagan myths of death and resurrection and the divinities' travels to the underworld were rendered through the composition of a story centered on the adventures, ordeals, seeming death, and miraculous return to life of a young loving couple; and how the images and metaphors of earthly physical love became transmuted into the symbols and concepts of a spiritual love for Christian virtues.

Bakhtin and Freidenberg study various manifestations and specific forms of discourse and narration and arrive at the conclusion that all literary genres are internally antinomic unities. Both recognize the anticipatory and the transforming energies of the genres that shape and give expression to the system of human knowledge. Yet an individual intention of the speaker, the form and the content of the discourse type, and the boundaries separating the speech genres from each other are envisioned by Freidenberg and Bakhtin quite differently.

Freidenberg's treatment of figurative and conceptual thinking and their metaphors concurrently explains the differences that exist between particular discourse genres. In Image and Concept (chapters 4-7) she forms a synchronistic perspective on the theory of genres and narration, however she does not discuss the reciprocal reflection of one discourse

${ }^{29}$ Freidenberg, "Proiskhozhdenie grecheskogo romana," 204. 
type upon the other (the problem which is at the heart of Bakhtinian theory). On the other hand, the entire corpus of her scholarly writings includes thorough discussions of those genres that remain, as it were, marginal for Bakhtinian perspective (her analysis of the archaic mimos, excursus into the genesis of ancient tragedy, and a thorough study of comedy-from the beginnings of Greek Old Comedy to the maturity of New, adapted to the Roman stage).

\section{Discussing Laughter in its Relation to Ritual}

Unlike Bakhtin, Freidenberg completed an extensive study of comic laughter, and like him, she began her analysis of the comic mode with the study of rituals and carnival performances. Bakhtin and Freidenberg felt quite comfortable amidst the carnivalesque diversity of speech types. Both treated differentiations and affinities as comparable phenomena and approached heterogeneity as a source of identity. The real differences between their contrastive interpretations of the same phenomena are to be found in their treatment of the culture of laughter.

Freidenberg discusses laughter in its relation to ritual, and she treats ritual as the most archaic form of collective worldview. ${ }^{30}$ At the acausal stages of cognitive development, laughter expressed the notion of the revitalization of dormant life forces. The rituals of laughter were enacted on fixed days of the seasons and in fixed places, and this rigid temporal and spatial framework conveyed the vitally important notion of the survival of the tribe. ${ }^{31}$ Vestiges of archaic ritual laughter were preserved and legitimized by later cultures: late Latin antiquity and medieval Christianity. Remarkably, the structure of the famous parodies

${ }^{30}$ Cf. O. Freidenberg, "The Origin of Parody," Semiotics and Structuralism, ed. Henryk Baran, 270-72, and Bakhtin, Problems of Dostoevsky's Poetics, 129.

31 Among Russian folklorists, Vladimir Propp held the position closest to both Bakhtin and Freidenberg (see chap. 6 of this study). In Theory and History of Folklore (125-26), Propp acknowledged the significance of Freidenberg's study of laughter and placed her writings, along with those of Usener, Reinach, and Fehrle, among the works that "have been of great use" to him, "especially with regards to classical material." Propp's Russkie agrarnye prazdniki (opyt istoriko-etnograficheskogo issledovaniia) (Leningrad: Leningradskii gosudarstvennyi universitet, 1963) provides a valuable complementary counterpart to Freidenberg in the area of Russian folk traditions. In his last, unfinished monograph, Problemy komizma i smekha (Moscow: Iskusstvo, 1976), 5-13, 141-44, Propp intended to discuss different modes and genre manifestations of laughter in their relation to the comic (5-13, 141-44). Unfortunately, the publishers failed to provide Propp's study with annotations which would have mapped out the areas the scholar had no opportunity to discuss and would thus have complemented his incomplete bibliography. 
of church services (processions of ragamuffins and soties) preserved the most meaningful components of the archaic semantics: the seasonal distribution of equidiurnal and solstitial rituals was preserved in mock processions that coincided with Christmas (winter) and Easter (spring). The setting of archaic rituals in the open fields was replicated by enacting the pageants in the cathedral squares of cities, and the metaphors of reviving solar forces were rendered through the figures of the obligatory participants in the mock ceremonies: an ass (the semantic remnant of solar deities) and a drunken maiden (the semantic cluster of fertility). A masked crowd that participated in the "La mère folle" festivals (during which a man in an inside out cloth and mounted backwards on an ass rode around the town) translated the images of the left-handed (or the sinister, the inverted and the false) into the right-handed (or the dexter, the good and the true.) As Freidenberg insisted, the mythological Dike/Hubris polarity had been preserved in archaic ritual laughter and in medieval carnival pageants as well.

As a mode of intuited collective perception characteristic of early pre-literate and acausal stages of cultural development, the comic existed face to face with the serious. Freidenberg argues that laughter was elicited by the non-identity of the illusions produced by the comic carnival performances, on the one hand, and the fundamental "seriousness" of allusions to the themes of rebirth, transfiguration, and resurrection, on the other. ${ }^{32}$ Ancient folklore, carnival and "archaic comicality" expressed the concept of fundamental seriousness through the images of laughter and disguise (thus carnival masks, pallia, grease-paint, and sleight of hand as forms of recognition of non-identity). ${ }^{33}$ The validity of the semantics of life-giving had to be collectively acknowledged in the forms of the comic, thus the paradigmatic pressure of seasonal and calendric recurrence coupled with the totemistic acknowledgment of the genius loci (the spirit of the place) contributed to the authority of the constructive power of laughter in seasonal ritual games and carnivals in ancient Roman and medieval cultures.

The ontology of the comic and of laughter, as well as the inquiry into the history of pre-mimetic aesthetic categories constituted the living nerve of Freidenberg's major studies, most of which (as Bakhtin's foot-

${ }^{32}$ Freidenberg, Poetika siuzheta $i$ zhanra, 198-224; "Prolegomenon to the Theory of Ancient Folklore," in $M L, 103-08,230-69$; "Palliata," 36-73. See also chap. 11.

33 Freidenberg, "Komicheskoe do komedii," 74-127. Cf. Freidenberg's terse formula "Cosmic order becomes manifest through comic details on the realistic, plausible plane" $(M L, 283)$ and our discussion of the "category of quality" in her works. 
note testifies) remained poorly available even to her native readers, not to mention scholars in the West.

Freidenberg demonstrated that folklore distinguishes itself from literature as one specificum from another. Thus, the question arises as to the relationship between oral and writing cultures, between old and new dynamic systems of collective awareness: "It is time that folklore cease being a quarry of discrete ahistorical facts" from which authors arbitrarily borrow elements for their works. ${ }^{34}$ Her analyses demonstrated that "folklore entered literature organically, as an element of the worldview on whose basis the literary work was created." An individual ancient author (like Aristophanes) could not ignore the accepted forms of aesthetic awareness, for, as the specificum, folklore worldviews had been built into his own outlook. Thus, in the Thesmophoriazussae, by ridiculing and parodying the ritual of the Thesmophoria festival in honor of Demeter, Aristophanes did not invalidate or subvert the sacred tradition, but rather perceived the sacred, religious features of the ritual as the subject-matter, the aesthetic object of his comedial (komediinyi) depiction. He "perceived reality through the prism of the folkloristic outlook as a stage in the development of consciousness whereby religion had lost its immediate content and was transmitted merely as form." 35 This is how the comedy of Aristophanes, this new artistic form of seeing concepts, had defined itself in literature, in reciprocal relation to other forms of communal self-expression: religious cults and mysteries, the well established traditions of domestic rites (oikonomia), and tragedies. Freidenberg insisted that Aristophanes' comedies were least of all intended to divest tragedies of their aesthetic values, for within this genre category, laughter and the new images of the comic addressed the same polarity of Dike and Hybris that had been expressed through the tragic mode.

\section{D. "Events in Life" and "Events of Life" as Two Possible Ways of Combining the Outside World with a Human Being}

Freidenberg's semantic theory of the comic operated at the junction of the emotive-perceptual and conceptual-cognitive planes in preliterate and literate cultures. According to Freidenberg, carnival belonged to the specificum of folklore, while carnivality and carnivalization with their manifest new qualities of a new relation to the object, are to be found within the specificum of literature. Resemantization of the components of folkloric genres within a more advanced specificum of literary plots made possible an adaptation of carnival to the needs of carnivality. This

\footnotetext{
${ }^{34}$ Freidenberg, "Fol'klor u Aristofana," 560.

${ }^{35}$ Ibid.
} 
carnivalization of archaic comic and tragic modes of seeing reality, however, characterized the parameters of an individual author's poetic Weltanschauung, and not the aesthetic views of a collective (the collective participants in carnival performances).

In Freidenberg's interpretation, the medieval carnival represented a cultural survival of primeval emotive and speculative world concepts, and she focused, therefore, on the genesis and genealogy of this cultural and poetic phenomenon. She insisted that in order to understand the meaning of medieval carnival and parody, one had to restore the concrete images and their real meaning contents, which had their origins in all the preceding stages of cultural development. The semantic reconstruction of the genres and plots that constituted various communal festivities, parodic performances, and farcical scenes (medieval as well as ancient) involved tracing them back to the antinomic identity of a tragic and comic order, i.e., the chilarotragedy, the rituals of the vivification of the totem (and of its collective embodiment-the tribe).

The separation of the cognizing consciousness from the world cognized, the translation of the concrete image-object into the imageconcept and the separation of subject from object (all correlated to one another through the formula "seen as") made it possible for Freidenberg to build a consistent, self-sufficient system of paired semantic nonidentities. The "seen as" component is a general signifier and the universal semantic correlate of her binary system. Thus the concrete image of the thing (object) and the perceivable form of the image belong to the realm of archaic folklore. Yet seen as the real meaning content of the thing (object) the concrete image is to be found as image-concept within the realm of literature. The narrative function of the myth belongs to the realm of archaic folklore, but an old mythic tale seen as "an indirect narrative about what was done and endured" brings about different types of narration, narrative modes, and separates the subject of the narrative (the author-poet in literature) from the object of narrative (the literary hero of the plot). Analogously, the illusion of miracles in mimos (performed by the mimes) seen as an allusion to divine deeds performed by divine agents brings about the "mimetic aspect," the new specificum of a theater performance and of a new genre of drama. Ritual laughter, archaic comicality, and ancient carnival seen in their specifically mimetic aspects bring about comedial laughter (komediinyi smekh), produce varieties of comedial genres and bring about a new quality, a new specificum of carnivalization and carnivalized genres in literature.

Summarized in this manner, Freidenberg's poetics does not divest Bakhtin's theory of its authority; rather it offers an interpretation of 
certain provocative and puzzling aspects of his aesthetics. ${ }^{36}$ As crucially important "events in life," carnivality, carnivalization, and chronotope find their appropriate place within Freidenberg's system; what Bakhtin treats as events of life (the life of an individual author, hero, and discourse genre), Freidenberg treats as one of the most complex symbolic forms of culture, and as a form of representation reality she moves it back into the life and life experience of archaic communities. Moreover, if one recalls the "revelation" Freidenberg experienced on 25 February 1943, her dictum "Being I saw as a morphology with its own new qualities-new in relation to the semantics" gains an unmistakably Bakhtinian overtone. Interpreted from a Bakhtinian position, Freidenberg's formula "seen as" becomes a component of a philosophy of being.

${ }^{36}$ See, for example, Wolfgang Rosler, "Michail Bachtin und die Karnevalskultur im antiken Griechenland," Quaderni Urbinati do Cultura Classica 23: 2 (1986): 25-44, who considers as particularly problematic the fact that Bakhtin did not include the Old Attic Comedy into his discussion of the serio-comical. 


\section{"O strange identity of my will and weakness!"}

To break out of the chaos of my darkness

Into a lucid day, is all my will

Stephen Spender, World within World 
Epilogue

\section{"O strange identity of my will and weakness!"}

W

ith Image and Concept already complete, Freidenberg added her brief "Explanation of the Theme" (19 August 1954) as an introduction to the manuscript and realized that she had "completed her racing." She had no plans for the future, no desire to continue living. In her last letter to Pasternak (17 November 1954) she wrote:

My beloved brother (speaking in the style of Father Zosima), I am laughing and crying at once. I have wanted to open my soul to you since long ago. I have suffered a great loss, an irreparable loss. I have lost my own self.

Yes, yes, I am a completely dead person $[d a, d a$, ia sovershenno ubityi chelovek]. I have withered and wasted away, I am suffocating. Mr. Bonnivard has never been my ideal, although tourists are enchanted by his place of residence. ${ }^{1}$ In Byron's place, I would never use the expression "chainless mind." He did not know the true taste of realism.

With this, all of the family news about myself comes to a final end. ${ }^{2}$

This sorrowful overview of her "Days" followed an inscription she added to the manuscript of Image and Concept as an epitaph:

I must begin with the same old thing: the prison-like conditions in which this book was written. I have no access to works of scholarship. I have to rely solely on my memory in writing this book. I am isolated from the ideas of contemporary scholars. Pupils and friends alike have turned away from me. I have been deprived of my university audience. Under the circumstances I

\footnotetext{
${ }^{1}$ Hero of Byron's Prisoner of Chillon. Freidenberg visited Chillon as a young tourist in 1911.

${ }^{2}$ Perepiska, 328. My translation is different from Mossman's. See Correspondence, 337.
} 
decided to synthesize my thirty-seven years of research and, having done so, to fall silent forever.

Passer-by! Pause before this work and pray for scholarship!

Ol'ga Freidenberg

20 March $1954^{3}$

This epitaph did not beseech a "passer-by" to lament over the destiny of a scholar whose creative mind was cast in fetters; neither did it seek "posthumous rehabilitation" for her own ideas. Rather it asked to bemoan the lot of scholarship (nauka), locked as it was in "the house of the dead."

Ol'ga Mikhailovna Freidenberg died on 7 July 1955. Maria Aleksandrovna Markova, her second cousin and the only person who remained at her death bed, wired the sad news to Boris Pasternak, but he could not attend the funeral. As if eager to materialize Freidenberg's archetypal metaphor "coming into view/disappearing," her colleagues placed no obituary in the university newspaper, nor did they convey a single word of sympathy to her relatives. Even her former students did not attend her funeral. Freidenberg was buried in the Bogoslovskoe Cemetery in Leningrad, but "not in the Academy plot, which was inaccessible [to her]."

One still wonders why thirty-seven years of research and service to the university led Freidenberg to voluntary seclusion and excommunication from the world of learning. Why did her colleagues and pupils remain reticent about her achievements not only in 1955, but also during the following years of thaw?

Among her colleagues Freidenberg was not a maverick, but a branded heresiarch, and any explanation for their reluctance to acknowledge her theories is ultimately to be found in epistemology, rather than in their submissiveness to the official ideology. Beginning with her master's thesis, Freidenberg approached Ancient Greek literature from the position of archaic pre-literate mythologies, being wholly aware of the fact that her innovative treatment divested classical literature of its classical halo. Her university teachers, professors S. Zhebelev, I. Tolstoi, and A. Malein, conversely, saw themselves as a small group bidden to uphold the traditions of the Petersburg school of classical philology. Forced to abdicate their individual dignity and class privileges, they refused to abdicate their meritorious yet conservative approaches to classical studies, and continued to honor nineteenth-century traditions in paleography, epigraphics, archaeography, and textual analyses of the

${ }^{3}$ Mossman, Correspondence, 339.

${ }^{4}$ M. A. Markova to B. L. Pasternak, 7 July and 10 July 1955, Correspondence, 343. 
great ancient authors. No wonder that during the official discussion of Freidenberg's master's thesis they expressed reservations about her methods, which substituted (in their view) speculations and conjectural inferences for philological analyses of primary sources. The confrontation over methods extends beyond Freidenberg's lifetime. In January 1974, during the celebration of the fortieth anniversary of the Department of Classical Philology, Professor Aristid Dovatur (a student of Zhebelev and an acknowledged teacher of Greek literature in Freidenberg's department) disparaged Berta Galerkina's public talk on Freidenberg's scholarship by sardonically calling it "public worship." In a private letter that followed the anniversary meeting, Dovatur wrote to Galerkina: "I consider myself a representative of the Leningrad school of classical philology, of which Ol'ga Mikhailovna was a complete negation [polnym otritsaniem kotoroi byla Ol'ga Mikhailovna]. I am a spokesman for Zhebelev, Tolstoi, S. V. Tolstaia, for S. Lur'e and I. M. Tronskii, not to mention A. V. Boldyrev and A. N. Egunov.... Yes, Ol'ga Mikhailovna was an extremely talented person, but all of her writings are beyond any criticism." Citing the authorities from four generations of the Petersburg classicists, Dovatur continued: "Ol'ga Mikhailovna's scholarship was philology with no texts, with no language, with no chronology." ${ }^{6}$ Dovatur wholly understood the epistemological foundation of his conflict with Freidenberg's approaches. He advocated philology in its ideal, "classical" definition: "the study of written records, especially literary texts, in order to determine their authenticity, meaning, etc." Freidenberg, conversely, insisted on the non-literary origin of all literary forms. She treated Ancient Greek literature as a form of written folklore and viewed narrative modes, genres, and poetic tropes as results of ongoing reinterpretations of archaic mythological semantics. This is why her supporters and allies have always been scholars working in philosophy of language, in the history of ideas and cultural history, but not classicists. ${ }^{7}$ This is why she was "rediscovered" by the founders of the

5 Aristid Ivanovich Dovatur to Berta L'vovna Galerkina, 16 January 1974. B. Galerkina's private papers.

${ }^{6}$ Ibid.

${ }^{7}$ Indicative are the titles of the works of Soviet and European scholars who initiated the reassessment of Freidenberg's legacy in the 1970s, and in the 1980s relied on her interpretations of mythological metaphors in their studies of historical poetics and semiotics of culture: Iu. M. Lotman, "O. M. Freidenberg as a Student of Culture," 257-69; Viach. Vs. Ivanov, Ocherki, 33-37, 48-50, 263; E. Meletinskii, Vvedenie, 8-10; Aage Hansen-Löve, "Zur Mythopoetik des russischen Symbolismus," Mythos in der Slawischen Moderne. Wiener Slawistischer Almanach Sonderband 20, 92-95; Jerzy Faryno, "Arkheopoetika 'Pisem iz Tuly' Pasternaka," ibid., 237-77; and Viacheslav Vs. Ivanov's foreword to the first English translation of Obraz i poniatie in which he explains that Freidenberg's 
famous Moscow-Tartu school of Semiotics, rather than by the young generation of classicists from her home university. ${ }^{8}$ Similarly, the Jubilee Scholarly Session dedicated to the 100th Anniversary of O. M. Freidenberg included in its program eight presentations of scholars who had no affiliations with the Department of Classical Philology, and only two papers of former students of Ol'ga Mikhailovna (the Leningrad classicists Berta Galerkina and Natal'ia Chistiakova). ${ }^{9}$

With her semantic approach, Freidenberg introduced a cross-disciplinary perspective to culture and from this position examined forms of signification of meaning at different stages of human social development. Discussing ancient Greek literature she sought connections with Jewish religious folklore and Egyptian and Assyrian mythologies, and found there "the compositional formants" which preshaped the basic meanings of Greek literary texts from later epochs. All of Freidenberg's writings are unified and solidified by her incessant interest in the fundamental transformational rule (her "seen as" principle) that underlies "the invariable nonidentity of semantics and its morphology" in primordial myths, in archaic representations of the Dike/Hubris polarity, in ancient comedy and tragedy, in Greek lyric poetry, in ethics and philosophy. The same transformational rule determines, in the final analysis, the categories of figurative and conceptual thinking, their structures and their metaphors. According to Freidenberg, the two-fold correlation of "that which is seen" and that which is "seen as" is the main operative factor that brings about a new metaphor of verbal arts and underlies transformations in social consciousness.

Freidenberg's metaphor establishes connections between phenomena, their manifested signs, and the general meanings of their manifestations. Thus metaphor is an inference into the substantial meaning of the phenomenal world. It signifies the final cognitive result in the progressing from apparent images to mental images. Considered from the

ideas precede various aspects of modern studies in structuralism, psycholinguistics, and the psychology of art. Even more characteristic, in his translation Kevin Moss changed Freidenberg's original heading into a bipartite title: Image and Concept: Mythopoetic Roots of Literature; his work has been published as a contribution to the series Sign/Text/Culture: Studies in Slavic and Comparative Semiotics.

${ }^{8}$ Characteristically, we owe the revival of Freidenberg's theory of genres in Greek antiquity to the efforts of N. V. Braginskaia, a classicist of the Moscow school of philology. See, for instance, her "Problemy fol'kloristiki i mifologii v trudakh O. M. Freidenberg," 181-89.

${ }^{9}$ B. L. Galerkina and N. A. Chistiakova, "Iubileinoe zasedanie posviashchennoe pamiati O. M. Freidenberg (k stoletiiu so dnia rozhdeniia)," Semiotika $i$ istoriia: Trudy po znakovym sistemam XXV (Tartu: Tartuskii gosudarstvennyi universitet, 1992), 144-50. 
position of the theory of knowledge, Freidenberg's definition of metaphor points to a new characteristic of the human in a social world and adds the fourth line, "Homo inferent," to the well-known triplet: "Homo sapiens," "Homo faber," and "Homo ludens." The latter formula brings to the fore the name of Johan Huizinga (whose ideas were unknown to Freidenberg). However, the characteristic properties of Huizinga's and Freidenberg's epistemologies are quite similar. Both start with the axiomatic acceptance of an archetype, and both rely on the effectiveness of inductive methods. Both observe large quantities of discrete individual facts and speak of the tendency to preserve standardization in a wide variety of forms of expression. Both associate the variety of symbolic forms with the morphology of culture and treat dissimilarity as the essential property of the unity of the cultural universe. On the basis of this tendency of culture to preserve identity despite distinct morphological differences, both scholars construe their holistic, noncontradictory pictures of the universe. In Freidenberg's theory, her mythological metaphor, coming-into-view/disappearing, provides representations for all phenomena of collective life. Huizinga approaches the forms of life, thought, and art through the significance of "the play element of culture," the archetypal and metaphorical expression of which he finds in the structure of the agon.

One should not forget, of course, that Freidenberg associated the dynamics of transformative processes with the competitive battle (agon) between the opposite forces of coming-into-view/disappearing, while Huizinga emphasized the agonistic principle of play, rather than destruction in cultural development. Thus, the more apparent the morphologic affinities are in Freidenberg's and Huizinga's writings, the greater the dissimilarities are among the emotive aspects in the concept of agon. Introducing agon through the images of game and emphasizing the essentially ludic character of competitions that animated civilization as well as the peoples' social ethics and morality, Huizinga made a heroic effort to "rechannel" the belligerent energies of rivalry, deceit, and political antagonism from universal destruction to cooperation and the "observance of play rules" in the relations between countries and states. ${ }^{10}$ On the eve of the Second World War Huizinga advocated his ludic principle, which would enable nations to "transcend the friend-foe relation" and, saving the humane element in civilization, to transform war to peace. In the late $1930 \mathrm{~s}$, he viewed himself as a prophet and petitioner for peaceful coexistence in the world of nations.

By contrast, Freidenberg viewed truth, justice, and atonement through the images of the "Moscow Nuremberg trial," and conceived of

${ }^{10} \mathrm{~J}$. Huizinga, Homo Ludens: A Study of the Play-Element in Culture (Boston: Beacon Press, 1950), 210. 
herself as a suppliant for recompense. Thus, the morphology of her agon is defined by single combat, rather than by game or play. Yet we also should remember how insistently Freidenberg repeated that the structure of agon as metaphor determined the competitive principle of the ancient Greek national sport games and festivals. It was preserved in the plot structures and dialogic exchanges of characters in ancient drama, in the composition of ancient Greek novels, and in philosophical heuristics. ${ }^{11}$ When Huizinga in his introductory discussion of the nature and significance of play stated that all hypotheses of play "start from the assumption that play must serve something which is not play," he actually relied on an equivalent of Freidenberg's "seen as" formula. The structures of human play symbolically represented for him the everlasting, invariably humane and complex event of culture which is to be preserved in the life of humanity. ${ }^{12}$ Analogously, in her "Genesis of Tragedy," Freidenberg observed that while social progress changes the structure of man's thinking, "culture, like the material world, remains indestructible," and its development is determined by the transformation of the function governing the basic struggle between the antinomic components of the mythological image. Thus, the oppositions of light and darkness, life and death, Dike and Hubris acquire religious, moral, and ethical functions. ${ }^{13}$

Reliance on archetypal metaphors in her treatment of semantics protects Freidenberg's methodology from the eclecticism which is so frequently present in syntagmatic approaches to the history of ideas and the anthropology of culture. Freidenberg traces the progression from pre-literate aesthetic models to individual forms of poetic awareness, from collective lore to the birth of individual discourse genres. Her semantic analyses trace the influence of morphogenesis on the intergeneric transformations, and her treatment of metaphor brings into the timeand-space universe of Greek antiquity signposts that mark the locations

${ }^{11} \mathrm{Cf}$. Freidenberg on agon, competitive battle in sport games, and dialogic exchange in drama (Poetika siuzheta $i$ zhanra, 124-27, 134-47, 221-29; ML, 49-62, 98-108, 419-23) and Huizinga on the play-concept as expressed in language and culture (Homo Ludens, 1-76).

12 In his foreword to the first edition of Homo Ludens, written on 15 June 1938, Huizinga traces the main stages of his work on the subject. He specifically refers to his lectures in Leyden, Zurich, Vienna, and London, which he delivered under the titles "Das Spielelement der Kultur" and "The Play Element of Culture." Each time, writes Huizinga, the organizers of his lectures tried to correct the title to "in" culture, and each time he protested, crossed out the preposition, and restored the genitive case, because, as he explained, "it was not my object to define the place of play among all the other manifestations of culture, but rather to ascertain how far culture itself bears the character of play." Homo Ludens, i.

13 Freidenberg, "Genesis of Tragedy," in $M L, 429,438-40$. 
at which discourse manifestations are recognized as "works," and works become inalienably bound with the names of the individual poets, their creators. 


\section{Index}

Aarne, Antti 60

Abaev, Vasilii Ivanovich 73 (fn. 8)

Academy of Sciences 71, 78, 84, 91

(fn. 56), 152, 153

Achilles Tatius 55, 56

Ackerman, Robert 59 (fn. 30)

The Myth and Ritual School 59

(fn. 30), 63 (fn. 43), 64 (fn. 47)

Adamovich, Ales' 189

Aeschylus 66

[Akhmat], Simeon Bekbulatovich

242,243

Akhmatova, Anna Andreevna 196

Alcaeus 212

Alpatov, Vladimir Mikhailovich

Istoriia odnogo mifa 73 (fn. 8),

76 (fn. 13), 79 (fn. 23), 83 (fn.

34), 158 (fn. 14)

$\mathrm{Al}^{\prime}$ tman, Moisei Semenovich 64,

112, 113-14, 154, 160

"Toward a Poetics of Homer"

("K poetike Gomera") 112 (fn.

34), 113

Ancient Theories of Language and

Style (Antichnye teorii iazyka $i$

stilia) 154,159

Annenskii, Innokentii Fedorovich

66

Apocrypha:

Acta apostolorum apocrypha

(also Tischendorf, Lipsius,

Bonnet, eds.) 47 (fn. 4), 49, 54, $55,56,58,60,257$

Acts of Paul and Thecla

(apocryphal acts of Thecla and Paul) 41, 47, 48, 49 (fn. 6), $51,52,53$ (and fn. 14 and 16),
54, 55 (and fn. 20), 56, 58, 87

(Falconila), 88, 113, 244

and Greek Romance (erotic novel) 55-58, 62, 63-64, 257 and archaic myths 58, 62, 63$64,86,140,244,257$

Aptekar', Valerian Borisovich 76

(fn. 14), 157-59

"N. Ia. Marr i novoe uchenie o iazyke" 76 (fn. 14), 158 (fn. 14)

"The Present Situation in the Linguistic Front..." 158 Apuleus 64

Archilochus 113, 229

Archiv für Religionswissenschaft 66 (fn. 51)

Aristophanes 107, 137, 140, 141, $142,154,225,260$

Plutus 140

Aristotle (and pre-Aristotelian metaphor) 38, 226-28, 230-31

The Atheist (Ateist) 52 (and fn. 12) Auerbach, Erich 3

"Vico and Aesthetic Historism" 82 (fn. 31)

Avvakum (Archbishop) 183-84

Azadovskii, Mark Konstantinovich 92 (fn. 56), 124, 125-26, 128-30 (and F. on folklore studies)

Istoriia russkoi fol kloristiki 128 (fn. 25)

"Pamiati N. Ia. Marra" 128 (fn.

23), 129 (fn. 26, 27, 28)

"Twenty Years of Soviet

Folkloristics" ("Sovetskaia 
fol'kloristika za dvadtsat' let")

128 (fn. 23), 130

Azadovskii, Konstantin

Markovich (and Egorov, B. F.)

"On Obsequiousness and

Cosmopolitanism" 197 (and fn. 6)

Bakhtin, Mikhail Mikhailovich 3, 81 (fn. 27), 249-49, 253-55, 258, 259, 261, 262

Art and Answerability 250, 251

(and fn. 9-11), 254, 255 (and fn. 23)

"Forms of Time and Chronotope in the Novel" 250 (and fn. 7)

Notebooks to Tvorchestvo

Fransua Rable 249 (fn. 3), 250 (fn. 4)

"The Prehistory of Novelistic Discourse" 252

"The Problem of Content, Material, and Form in Verbal Art" 254

"The Problem of Speech Genres" 254

Problems of Dostoevsky's Poetics 225 (fn. 24), 256, 258 (fn. 30)

Rabelais and his World 249 (fn. 3), 250

Balukhatyi, Sergei Dmitrievich 198

Baranov, Nikolai Petrovich 112

"Mana in Homer" ("Manna u Gomera") 112 (fn. 34)

Barnes, Christopher

Boris Pasternak: A Literary

Biography 25 (fn. 15)

Bauman, Karl 157, 158

Bedier, Joseph 60, 121

Beethoven, Ludwig von 10, 11

Beneshevich, Vladimir

Nikolaevich 152 (fn. 2)
Bergson, Henri 78

Beriia, Lavrentii Pavlovich 128

Berlin, Isaiah 113 (fn. 36)

Beskina, A. 92 (fn. 56)

Bestuzhev Courses (Bestuzhevskie kursy) 2, 4 (fn. 6), 46 (fn. 3)

Bible 28, 78, 86, 107, 108, 247

Acts 54, 55

Chronicles 50

Epistles 54

Genesis 28, 29

Gospels (and Gospel mythology) $41,60,64$

The Holy Scriptures 40

Isaiah 6

New Testament 50, 247

Old Testament 65, 247

Bidney, David

"The Philosophical

Anthropology of Ernst

Cassirer" 115 (fn. 40)

Bocharov, Sergei Georgievich

The "Complete Works" of M.M.

Bakhtin (ed.) 249 (fn. 2)

Bogaevskii, Boris Leonidovich 84, 108, 109, 111, 123

Bogatyrev, Petr Grigor'evich 139, 143-47 (and F. on diachronic and synchronic approaches to folklore -?-)

The Function of Folk Costume...

144 (fn. 36, 37, 38)

Magic Acts, Rites, and

Customs... 144, 146

Voprosy teorii narodnogo

iskusstva 144 (fn. 36), 145 (fn.

39, 40), 146 (fn. 43, 44)

Bogdanov (Malinovskii), Aleksandr Aleksandrovich 76

Boldyrev, Aleksandr Vasil'evich 267

Bolschewistische Wissenschaft und Kulturpolitik 188 
Borozdin, Aleksandr Kornil'evich 19, 46 (fn. 1)

Protopop Avvakum 59 (fn. 28)

Bowra, C. M. 212

Greek Lyric Poetry from

Alcman to Simonides 208 (fn. 27), 212 (fn. 40)

Boyd, Brian

Vladimir Nabokov: The American Years 35 (fn. 35)

Braginskaia, Nina Vladimirovna 1 (fn. 1), 34 (fn. 33), 36 (fn. 37), 70 (fn. 2), 71 (fn. 3), 101 (fn. 6, 7), 132-33, 141, 165, 268

"O rabote O. M. F. 'Sistema literaturnogo siuzheta"' 132-33 (and fn. 2, 3), 141 (fn. 26)

"Problemy fol'kloristiki i mifologii v trudakh O.M. F." 133 (fn. 3), 268 (fn. 8)

Brim, B. A. 122

Bush, Vladimir Vladimirovich 47

Bukharin, Nikolai Ivanovich 30 , 161, 162

Bushkovitch, Paul 245, 246 "The Epiphany Ceremony..." 245, 246

Bykovskii, Sergei Nikolaevich 158

Calderón de la Barca, Pedro 133, 139

Cassirer, Ernst 30, 76, 81, 89-92, 99-104, 106-07, 108, 111 (fn. 31), $112,114,115,117,136,162$, $163-64,165,178,179,186,205$, 213

An Essay on Man 100, 163 (fn. 26), 179, 205 (fn. 22), 213 Language and Myth 81, 89, 90 (and fn. 51, 53), 101 (fn. 8), 104 (fn. 16), 106 (fn. 21), 112 (fn. 33)
"Logos, Dike, Kosmos in der Entwicklung der griechischen Philosophie" 205 (fn. 23) "The Myth of the State" 162-63 The Philosophy of Symbolic

Forms 81, 89, 90 (and fn. 52), 100,205

Cervantes Saavedra, Miguel de

133

Charskaia, Lidiia Alekseevna 35

Chistiakova, Natal'ia

Aleksandrovna 268

Chistov, Kirill Vasil'evich 242, 243-43

Russkie narodnye sotsial'noutopicheskie legendy 242 (fn. 9)

Chion and Heraclea 55-56

Christianity (Christology, Christian theology, Christian legends) $33,34,40,48,52,54$, $55,59,60,62,64,66$ Clark, Katerina 74-75, 79 Petersburg: Crucible of Cultural Revolution 75 (fn. 12), 77 (fn. 16), 79 (fn. 23), 82 (fn. 30), 83 (fn. 35)

The Soviet Novel 79 (fn. 23) Cohen, Hermann 18, 19, 30

The Communist Academy

(Komakademiia) 30, 157, 158

Coseriu, Eugenio 63, 213 Sprache: Strukturen and Funktionen 213 (fn. 37)

Dante, Alighieri 82 "De vulgari eloquentia" 82 Deborin, Abram Moiseevich 81 "Novoe uchenie o iazyke i dialekticheskii materializm" 81 (fn. 29)

Democritus 81

Derrida, Jacues

Dissemination 215 (fn. 3) 
Derzhavin, Gavriil Romanovich

"A Slate Ode" ("Grifel'naia oda") 28 (fn. 29)

Derzhavin, Nikolai

Savost'ianovich 134 (and fn. 9)

Desnitskii, Vasilii Alekseevich

134-35 (and fn. 3)

Dieterich, Albrecht 223

Dmitriev, Ivan Ivanovich 20 (fn. 8)

D'iakonov, Igor' Mikhailovich 71 (fn. 3)

Dobrogaev, Sergei Martinianovich

"The Phoneme as a

Psychological and Social

Phenomenon" ("Fonema kak

fiziologicheskoe i sotsial'noe iavlenie") 78 (fn. 21)

Dolgopol'skii, Aron Borisovich 72 (fn. 6)

Dondua, Karpez Darispanovich

122

Dostoevskii, Fedor Mikhailovich

197

The Brothers Karamazov

(Father Zosima) 265

Dovatur, Aristid Ivanovich 154, 267

Driagin, Nikolai Mikhailovich 122

Eco, Umberto 1

Egorov, Boris Fedorovich (and

Azadovskii, K.)

"On Obsequiousness and

Cosmopolitanism" 197 (and fn. 6)

Egunov, Andrei Nikolaevich 154, 267

Efron, Ariadna Sergeevna 36-37

Pis'ma iz ssylki 37 (fn. 38)

Eikhenbaum, Boris Mikhailovich

134-35, 136, 196, 197, 237 (fn.

10)

“Diary 1946" 197
Eisenstein, Sergei Mikhailovich 237 (fn. 1), 241 (fn. 8)

Emerson, Caryl (see Bakhtin, M.,

Dialogic Imagination, trans.)

Endiukovskii, A. G. 122

Engels, Friedrich 76

Epstein, M. S. 159

Euripides 6, 238

Helen 238

Ezhov, Nikolai Ivanovich (and

Yezhovshchina) 184, 187 (fn. 9)

Fadeev, Aleksandr

Aleksandrovich 196

Faryno, Jerzy

“Arkheopoetika 'Pisem iz Tuly' Pasternaka" 267 (fn. 7)

Fedorov-Cheliadin, Ivan

Petrovich 242, 243

Fehrle, Eugen 258 (fn. 31)

Fleishman, Lazar'

Stat'i o Pasternake 22 (fn. 12)

Flier, Michael 245, 246, 247

"The Iconography of Royal Procession..." 245, 246, 247

"The Iconology of Royal Ritual" 245

Frank-Kamenetskii, Izrail'

Grigor'evich (Khona) 5, 40 (fn.

43), 81, 83-88; 89-92, 94, 99, 106-08, 111-12, 121, 123, 129, $154,156,158,159,161,178,184$, 237

writings:

"Adam and Purusjah"

("Adam i Purusha") 91 (and fn. 55), 108 (fn. 25)

"Itogi kollektivnoi raboty..."

123

Pamiatniki egipetskoi religii

85 (fn. 38)

"Parting as a Metaphor for

Death" ("Razluka kak 
metafora smerti") 91 (and fn. 55), 108 (fn. 25)

"Primeval Thinking"

("Pervobytnoe myshlenie...") 81 (fn. 28), 89-92, 108, 112 (fn. 33)

Prophets-Thaumaturges

(Proroki-chudotvortsy) 85

(fn. 38), 86, 87 (and fn. 41)

"Survivals of Animism in Biblical Poetry"

("Perezhitki animizma...")

91 (and fn. 55), 108 (fn. 25)

"Vegetation and Agriculture in the Poetic Images of the Bible" ("Rastitel'nost' i zemledelie") 91 (and fn. 55), 108, 112 (fn. 33)

"Water and Fire in Biblical Poetry" ("Voda i ogon' v bibleiskoi poezii") 85 (and fn. 38), 87 (fn. 43), 88 (fn. 46)

Frazer, James George 59 (and fn. 30), 242

The Golden Bough 242 (fn. 11)

Freidenberg, Aleksandr (Sasha), brother of O. M. (and Musia, his wife) 5 (fn. 7), 10, 18, 184

Freidenberg, Anna Osipovna (nee

Pasternak, also Asia), mother of O. M. 4, 17 (fn. 1), 18, 27, 190-91

Freidenberg, Mikhail Fedorovich

(Moisei Fillipovich), father of O.M. 4,18

Freidenberg, Ol'ga Mikhailovna theory, terminology: antinomic identity (internal identity and external diversity) $34,35,50,64,100$ $06,228,239-38$ archetypal elements (mythological metaphors, metaphor) 25, 31 (fn. 25), 32,
$33,62,100,104,169-70,172-$ $74,176,178,218,219,228$, 230-31, 261, 268-67, 270 compositional formants

("morphemes,"

"transcriptions") 51, 56, 60, $61,62,63,87,245$

genetic method $25,31,32,63$,

$92,111,118-19,211-12$

historical aesthetics 200-05, 211

morphology (in relation to semantics) 106, 167, 217, 222

perceptual-conceptual

transformation (also the real and the apparent) $100,104-05$, $138,167,170-74,212-14,217-$ 18, 227-28, 232, 257

semantics (also semantic

paleontology and the transference of semantic values) $39,40,101-06,110-12$, 114, 117-24, 213-14, 237, 23939,247

separation of the cognizing subject from the cognized object $32,33,220-21,252-51$, 261

writings:

"The Architectural Semantics of the Vertep Theater," see "The Semantics of the Structure of the Puppet Theater"

"Asselliana" (see also "Entry into Jerusalem upon an Ass") 52-53, 64

"An Ass-Symbol of Salvation" 64 (and fn. 48)

"Blindman over the Precipice" ("Slepets nad obryvom") 106, 107 (fn. 22), 114 (fn. 39), 139, 140-42

The Collective Study of the Plot of Tristan and Iseult 
(also Tristan and Iseult, and Tristan i Isol'da) 117, 119, $120,122,123,125,129,165$, 170

"The Comical before Comedy" ("Komicheskoe do komedii") 127 (fn. 28), 223, 224, 227, 231, 259 (and fn. 33)

Correspondence with Boris

Pasternak (see also

Pasternak, and Mossman, Correspondence) 7, 22, 27, 28-30, 35-36, 195, 200, 265

"The Cross at the Grave" 146 (fn. 45)

"Entry into Jerusalem upon an Ass" ("V"ezd v Ierusalim na osle") 64 (fn. 48), 246, 247 (fn. 24)

"Folklore in Aristophanes" ("Fol'klor u Aristofana") 118-19 (and fn. 2, 3), 137, 142 (fn. 30), 155, 260 (and fn. 34)

"Fragment I, Sappho" ("Fragment I, Safo") 199, 201 (fn. 15)

"From Pre-Homeric Semantics" ("Iz dogomerovskoi semantiki") 155 (and fn. 8), 215 (fn. 3), 240, 241, 242, 243

"The Gospel-One Type of Greek Novel" ( "Evangelieodin iz vidov grecheskogo romana") 52 (and fn. 12), 256

"The Greek Novel as Acts and Passions" "Grecheskii roman kak deianiia $i$ strasti") 52, 113

Image and Concept (Obraz $i$ poniatie) 1 (fn. 1), 32, 167,
177 (fn. 28), 192, 215, 217, 219-22, 225, 226, 227-28, $233,234,248,255,257,265$

Letters to members of $\mathrm{L}$.

Pasternak's family (also Pasternak Trust) 5 (fn. 7), 30 (fn. 24), 155-56, 162

"Literary Genesis of the Odyssey" 64 (fn. 48)

"The Main Goals used in the Collective Study of the Plot of Tristan and Iseult"

("Tselevaia ustanovka...") 121

"The Methodology of One Motif" ("Metodologiia odnogo motiva") 133-34, 135, 146 (fn. 45) Mif $i$ literatura drevnosti 1 (fn. 1), 53 (fn. 14), 144 (fn. 36), 270 (fn. 11, 13)

"The Myth about Joseph the Beautiful" ("Mif ob Iosife Prekrasnom") 106, 107, 114 (fn. 39)

"On the Basic Characteristics of Greek Literature" ("Ob osnovnom kharaktere grecheskoi literatury") 201, 207, 208 (fn. 27)

"On the Origin of Greek Metrics" ("K voprosu o proiskhozhdenii grecheskoi metriki") 198, 213 (fn. 46), 214

"On the Semantics of the Folkloric Proper Names Makkus and Mariia" 104, 215 (fn. 3), 238 (fn. 3), 243 (fn. 13)

"On Stable Plots and Wandering Theoreticians" ("O nepodvizhnykh 
siuzhetakh i brodiachikh teoretikakh") 36 (fn. 37)

"On Static Plots and

Wandering Theoreticians" 135,139

"The Origin of the Greek

Lyric" ("Proiskhozhdenie grecheskoi liriki") 31,32 (and fn. 27), 201 (fn. 15), 202, 203-05, 212 (fn. 38), $229,252,254$

The Origin of the Greek Novel ("Proiskhozhdenie grecheskogo romana," also The Greek Novel as Acts and Passions, also "The Acts of Thecla") $32,33,34,40,41$, 48, 49-53 (and fn. 11, 12, 16), 56 (and fn. 21, 22), 61 (and fn. 34),62, 63 (and fn. 45), 66, 85, 243, 244 (fn. 15), 256

"The Origin of Epic Simile"

("Proiskhozhdenie epicheskogo sravneniia") 30 (fn. 23), 171 (fn. 15), 192, 197, 231, 232, 254

"The Origin of Parody" ("Proiskhozhdenie parodii") 211, 258 (and fn. 30), 258 (fn. 30)

"Palliata" 192, 195 (fn. 1), 223 (fn. 19), 238

"The Plot of Tristan and Iseult..." ("Siuzhet Tristana i Izol'dy..") 123 (and fn. 14) "The Plot Semantics of the Odyssey" ("Siuzhetnaia semantika 'Odissei") 29, 64 (fn. 48), 109-12, 113, 114 The Poetics of Plot and Genre (Poetika siuzheta i zhanra also "Procris," Prokrida) 1 (fn. 1), 30, 34 (and fn. 33),
40, 85, 91 (fn. 55), 93-95, 99, 104, 106 (fn. 20), 115 (fn. 41), 133 (fn. 5), 144 (fn. 36), 149 (epigr) 156, 160, 161, 162, 164, 165-70, 170-74, 175-76, 177-79, 197, 209-10 (fn. 34), 211, 213 (fn. 43), 215 (fn. 3), $217,239,241,249,250,253$ (and fn. 16), 259 (fn. 32), 270 (fn. 11)

Prolegomenon to the Theory of Ancient Folklore (also Lectures and Vvedenie $v$ teoriiu antichnogo fol'klora) 1 (fn. 1), 99, 175 (fn. 23), 192, 218-19 (fn. 6-8), 242 (fn. 9), 251-50, 253 (and fn. 58), 259 (fn. 32)

The Race of Life (also diaries, memoirs, Probeg zhizni), 2 (and fn. 3) 3, 5-12, 17, 18, $19,20,21,22-23,24,25-26$, $34,35,36,37,38,45,46,47$, 48, 53 (fn. 14), 55 (fn. 20), 63 (fn. 46) 64 (fn. 48), 65, 66 (fn. 51), 67-68, 69, 70, 79, 84, 85, 86, 93-96, 105-06, 112, 113, $118,123,124,125,126,127$, $130,134-35,136,139,143$, $154,156,157,158,160,162$, 163-64, 178, 183-84, 185, 187, 188-89, 190-92, 195 (fn. 1), 197, 198, 216-17, 237, 249 "Recollections: On N. Ia. Marr" ("Vospominaniia o N. Ia. Marre") 70 (fn. 2), 71 "Sappho" ("Safo") 199-200, 201 (fn. 15)

Sappho. Toward the Origin of Greek Lyrics (Sapfo [K proiskhozhdeniiu grecheskoi lirikiJ) 28 and 28 (fn. 19) 
The Semantics of the Composition of Hesiod's "Works and Days"... 39 "The Semantics of the First Thing" ("Semantika pervoi veshchi") 175 (fn. 24)

"The Semantics of the Structure of the Puppet Theater" (also "The Architectural Semantics of the Vertep Theater," "Semantika postroiki vertepnogo teatra") 100 (and fn. 4), 101-06, 144, 170

"The System of the Literary Plot" ("Sistema literaturnogo siuzheta") 141, 144

"The Teaching of the Greeks about the Upheaval" ("Uchenie grekov o perevorote") 7 (fn. 12), 3839

Tezisy $k$ doktorskoi dissertatsii 168 (and fn. 6), 170 (fn. 13)

"Thamarys" 88 (fn. 44, 46)

"Three Plots or the Semantics of One" ("Tri siuzheta ili semantika odnogo") 29-30, 133, 134, 138 (fn. 19, 20), 170

Tristan and Iseult, see Collective Study

Frye, Northrop 3, 57, 58 Anatomy of Criticism 58 (and fn. 27)

The Secular Scripture 57 (fn. 24)

Gagen-Torn, Nina Ivanovna

Memoria 4 (fn. 6), 124 (fn. 17)

Galerkina, Berta L'vovna 197, 267, 268

Garibaldi, Giuseppe 6

Gasparov, Boris Mikhailovich
"Poetika Pasternaka" 18 (fn. 4), 26 (fn. 16), 31 (fn. 25)

Gavronsky, Dmitry

"Ernst Cassirer: His Life and

His Work" 163 (fn. 27),164 (fn. 29)

Genko, Anatolii 67

Ginzburg, Carlo 3

Ginzburg, Lidiia Iakovlevna 186, 189, 197, 207 (fn. 25)

Chelovek za pis'mennym stolom 186 (fn. 7)

Notes of the Besieged 189

Goethe, Johann Wolfgang 12, 187

(fn. 9)

Gogol, Nikolai Vasil'evich

Mirgorod 210

Gorbanevskii, Mikhail

Viktorovich

V nachale bylo Slovo 76 (fn. 14)

Graham, Loren

The Soviet Academy of Sciences and the Communist Party 153 (fn. 5)

Granin, Daniil Akeksandrovich 189

Greimas, Algirdas Julien 63

Grevs, Ivan Mikhailovich 84 (fn.

37)

Gukovskaia, Natal'ia Grigor'evna

"Otets" 206 (fn. 25)

Gukovskii, Grigorii

Aleksandrovich 186, 200, 201, 205-06, 208, 209, 210, 211

"O russkom klassitsizme" 209 (fn. 32)

Pushkin i problemy realisticheskogo stilia 209 (fn. 33)

"Russian Classicism" 208 (fn. 28), 209

"Towards the Problem of Russian Classicism" 201 (and fn. 14), 207 
"Toward the Question of the

Image of the Narrator..." 210

Gumpel, Liselotte 226, 227, 230

Metaphor Revisited 226, 228-29

(fn. 35, 36), 230-31

Gutan, Ol'ga Aleksandrovna 197

Hansen-Löve, Aage

"Zur Mythopoetik des

russischen Symbolismus" 267 (fn. 7)

Harnack, Adolf von 52, 53 (fn. 14),

$54,59,60,62,63,71$ (fn. 4)

The Mission and Expansion of

Christianity 54 (fn. 18), 60 (fn.

32), 62 (fn. 39), 63 (fn. 41, 42)

Hartman, Robert

"Cassirer's Philosophy of

Symbolic Forms" 99 (fn. 1)

Hawkes, Terence 228

Hegel, Georg Wilhelm Friedrich

(and Hegelian) 205

Heliodorus

Ethiopian Story (and the apocrypha) $\mathbf{5 5}$

Herder, Johann Gottfried 82

Hermitte, René

Marr, marrisme, marristes 75

(fn. 13)

Herzen (also Gertsen), Aleksandr Ivanovich 6, 7, 8, 9 (fn. 16), 11 My Past and Thoughts (Byloe $i$ dumy) and Freidenberg's memoirs) 6-12

Hesiod 4, 28, 39

Works and Days 28, 39

Hipponax 212

Hitler, Adolf (and Hitlerism) 184, 185,187

Holquist, Michael (see Bakhtin, M., The Dialogic Imagination, ed.)
Homer 88, 108, 110, 111, 114, 181

(epigraph), 223, 224, 238, 240

Iliad 108, 109, 110, 111, 165,

$173,223,231,238,240-39$

Odyssey 108, 109, 110, 111

(Odysseus), 114 (Odysseus,

Telemachos), 165, 181, 223,

238

Homer and the Japhetic Theory 108-12

Huizinga, Johan 3, 269, 270

Homo Ludens 269 (fn. 10), 270

(fn. 11)

Hugo, Victor 6

Humboldt, Wilhelm 178 (fn. 32)

Iafeticheskii sbornik 82 (fn. 32 ), 88

(fn. 44), 102 (fn. 9)

Iakovlev, Nikolai Fedorovich 239 (fn. 4)

Iakovlev, Nikolai Vasil'evich 135

Iakubchik, Anastasiia Iosifovna 189 (fn. 12)

Iaroshenko, Nikolai

Aleksandrovich 200

Iazyk i literatura 30 (fn. 23), 108 (fn. 26)

Inber, Vera Mikhailovna 188

Institute of the History of Western and Eastern Literatures and Languages (ILIaZV) 67, 69, 83, $84,85,134,139,151$

Institute of Language and

Thought (Institut Iazyka i

Myshleniia, IiaM, also Japhetic

Institute) $84,85,108,151,154$,

$155,159,237$

Institute of Speech Culture

(Institut rechevoi kul'tury, IRK)

36 (fn. 37), 135, 151, 154, 155,

159,237

Ioffe, Ieremiia Isaevich 237 (fn. 1)

Isis-Osyris myths $56,58,87^{*}$ 
Iudina, Mariia Veniaminovna 189 (fn. 12)

Iunov, Dmitrii 91-92 (fn. 56)

Ivan the Terrible 242, 246, 247, 248

Ivanov, Viacheslav Ivanovich 53, 66, 84, 199 (fn. 11)

Dionysus and Pre-Dionysianism

(Dionis i pradionisiistvo) 53 (and fn. 15)

Ivanov, Viacheslav Vsevolodovich

73 (fn. 8), 132 (fn. 2), 237 (fn. 1), 239, 268 (fn. 7)

Ocherki po istorii semiotiki 239 (fn. 4), 267 (fn. 7)

"Vvodnye zamechaniia $\mathbf{k}$ stat'e..." 132 (fn. 2)

Izrailevich, Liubov' Semenovna

"Triumph" ("Torzhestvo") 156 (fn. 156)

Izvestiia 156 (fn. 11), 159, 160 (fn. 19), 161

Jakobson, Roman 136, 145

Joravsky, David

"The Construction of the

Stalinist Psyche" 153 (fn. 6)

Jung, Karl 81

Kant, Immanuel (and Kantian, neo-Kantian) 6, 81, 91, 92, 93 (and fn. 58), 205

Karsavin, Lev Platonovich 66

Kazanskii, Boris Vasil'evich 122, 136

Kelly, Aileen

"Empiriocriticism: A Bolshevik Philosophy" 76 (fn. 14)

Kerényi, Karl 57, 58, 64

Die Griechisch-Orientalische Romanliteratur 57 (fn. 24), 64 (fn. 48)

Ketlinskaia, Vera Kazimirovna 188
Kheraskov, Mikhail Matveevich 208

Kholodovich, A. 92 (fn. 56)

Kirov, Sergei Mironovich 153

Klemperer, Victor

LTI 187

Komarovich Vasilii Leonidovich 84

Kropacheva, Mariia

Viacheslavovna 189 (fn. 12)

Lapidus, Gail Warshofsky 151

"Educational Strategies and Cultural Revolution..." 151 (fn. 1)

Lapshin, Ivan Ivanovich 46

Latynin, Boris Aleksandrovich 122

Lebedev-Polianskii, Pavel Ivanovich 159, 160, 161, 162

Leiteizen, Tsilia [Sesil' Gavrilovna $156,159,161$

"Pernicious Balderdash"

("Vrednaia galimat'ia") 156

(fn. 11)

Lenin, Vladimir Il'ich 128

"Notes to Aristotle's

Metaphysics" 158 (fn. 14)

Lermontov, Mikhail Iur'evich 133, 139

Lesage, Alain-René 140

Lévy-Bruhl, Lucien 3, 76, 78, 81, 112,145

Lévi-Straus, Claude 3, 63, 228

Liapunov. Vadim 250-49 (fn. 8)

"Notes" to Art and

Answerability 251

"Notes on Bakhtin's

Terminology" 251 (fn. 8)

"Translator's Preface" to Bakhtin, M., Toward a Philosophy of the Act 251 (fn. 8)

Likhachev, Dmitrii Sergeevich How We Stayed Alive 189 
Likhachev, Nikolai Petrovich 152 (fn. 2)

Linguistic Front (Iazykofront) 83, 117 (fn. 1), 157

Literary Encyclopedia 159

Literary Heritage 159

Liubishchev, Aleksandr Aleksandrovich 132 (fn. 2)

Livshits, Motia (Matvei

Borisovich) 47

Ljunggren, Ana Juvenilia 25 (fn. 15)

Lomonosov, Mikhail Vasil'evich 208

Lonsdale, Steven $\mathrm{H}$ Creatures of Speech... 172 (fn. 16), 232 (fn. 44)

Losskii, Nikolai Onufrievich 46

Lotman, Iurii Mikhailovich "Ol'ga Mikhailovna Freidnberg as a Student of Culture" 239 (fn. 6), 267 (fn. 7)

Lucian 64, 140

Lunacharskii Anatolii Vasil'evich 69,76

Lur'e, Solomon Iakovlevich 127 , 154, 267

Lysenko, Trofim Denisovich 79

Maiakovskii, Vladimir

Vladimirovich 19

Malein, Aleksandr Iustinovich 154, 266

Markova, Mariia Aleksandrovna (née Margulis) 11-12, 266

Marr, Nikolai Nikolaevich 2, 5, 54 (fn. 19), 66-67, 69-83; 84, 86, 88, 89-92, 93, 94, 100, 102, 104, 105-06, 108, 109-10, 111, 112, $115,117-21,123,124,125,129$, $130,138,143,151,155,158,174$ (fn. 21), 178, 191,211 (fn. 37), 215, 216, 218, 239 theories:
Japhetic theory (Japhetidology, Japhetism) 69 (fn. 1), 70, 72, 73, 74, 78, $84,85,89$

New Teachings on Languages 5, 76 (fn. 13), 78, 81, 83, 112, 157, 158

Paleontology of culture (also semantic paleontology) 73 , $77,78,100,102$

prelogical thinking (dologicheskoe myshlenie) 89-92

stage development $74-75,80$, 94, 108-09, 117

writings:

"Balavaar's Wisdom" (Barlaam and Josaphat legend) 71 (fn. 4)

"Death as the Netherworld..." ("Smert'-preispodniaia...") 109 (fn. 28)

"Denomination of the Etrurian God of Death..." ("Nazvanie etrusskogo boga smerti...") 82 (fn. 31), 109 (fn. 28)

"The First Mediterranean House" 88 (fn. 45), 102, 104 Following the Landmarks of Japhetic Theory (Po etapam razvitiia iafeticheskoi teorii) 89

"From a Journey to the European Japhetides" ("Iz poezdki k evropeiskim iafetidam") 82 (and fn. 32 , 33 ), 119-20 (and fn. 4, 5, 6, 7)

"Iafetidy" 90 (and fn. 51)

Iazyk i myshlenie 77 (fn. 19) "Ishtar..." 119, 120-21 (and fn. 8), 129 
"Ob iafeticheskoi teorii" 77-

78 (and fn. 16, 17, 18)

"On the Interpretation of the

Name 'Homer'" 88 (fn. 45)

"Ossetica-Japhetica" 74 (fn.

11)

Proceedings of the Russian Academy of Sciences

(Doklady Rossiiskoi

Akademii Nauk) 89 (and fn. 49)

Proceedings of the Russian Academy of the History of Material Culture (Izvestiia Rossiiskoi Akademii...) 89 (and fn. 49)

"Why It Is So Difficult to Become a Theoretical Linguist" ("Pochemu tak trudno stat' lingvistomteoretikom") 76-77 (fn. 15), 78 (and fn. 21)

Marx, Karl (also Marxism) 76, 83, 118, 160, 177, 191, 205, 206

Maupassant, Guy de

Mont Oriol 8-10

Mazzini, Giuseppe 6

Meletinskii, Eleazar Moiseevich 239, 267 (fn. 7)

"Istoricheskaia poetika A. N.

Veselovskogo..." 239 (fn. 5)

Melikova-Tolstaia, Sofiia

Venediktovna 154, 267

Merkelbach, Reinhold

Roman und Mysterium in der

Antike 57 (fn. 24)

Meshchaninov, Ivan Ivanovich 80 , 84, 159, 239 (fn. 4)

N. Marr, Iafeticheskiai teoriia 76 (fn. 14)

Osnovnye nachala iafetidologii

76 (fn. 14)

"Problema stadial'nosti" 80 (fn.

26)
Michelet, Jules 6

Michurin, Ivan Vladimirovich 79

Michurina-Samoilova, Vera

Arkad'evna 189 (fn. 12)

Mikhankova, Vera Andreevna

Nikolai Iakovlevich Marr 78 (fn.

22)

Minucius Felix 41 (and fn. 45)

Montagu, Ashley

"Cassirer on Mythological

Thinking" 92 (fn. 57)

Moss, Kevin M. 1 (fn. 1), 2, 79, 228

Image and Concept:

Mythopoetic Roots of

Literature 268 (fn. 7)

"Olga Mikhailovna

Freidenberg" 72 (f. 5), 79 (fn.

23)

Mossman, Elliott

Correspondence 3 (fn. 4, 5), 7

(fn. 11), 12 (fn. 18), 17 (fn. 1), 20 (fn. 10), 27 (fn,. 17, 18), 28

(fn. 20), 30 (fn. 23, 24), 34 (fn.

32 ), 35 (fn. 34 ), 36 (fn. 36 ), 53

(fn. 14), 157 (fn. 12), 160, 161,

$162,164,195-96,198,200,215$

(fn. 2), 252 (fn. 15), 265 (fn. 2),

266

"Mother Earth" myths 54, 56

Nabokov Vladimir

Selected Letters 35 (fn. 35)

New Testament Apocrypha

(Wilhelm Schneemelcher and A.

J. B. Higgins, eds) 49 (fn. 6)

Nicholas I 6

Nikolaeva, Tat'iana

"This Blind Homer" ("Etot

slepets Gomer") 159

"Teofrast i drugie" 159 (fn. 16)

Nietsche, Friedrich 33, 65, 66

Norden, Eduard 49 (fn. 7), 52, 59 
Odissei: Chelovek $v$ istorii 36 (fn. 37)

Ogarev, Nikolai Platonovich 7, 9 (fn. 16) "Humor" 7-8

Henry, $\mathrm{O}$.

"The Last Leaf" 231

Oinas, Felix Folklore, Nationalism, and Politics 124, 128 (fn. 25)

Ol'denburg, Sergei Fedorovich 155

Ong, Walter 3

Orwell, George

1984196

Ostroumova-Lebedeva, Anna

Petrovna 189 (fn. 12)

Ottokar, Nikolai Petrovich 84 (fn. 37)

Page, Denys

The Homeric Odyssey 57 (fn. 24)

Parson, James 72

Passek, Tat'iana Sergeevna 84, 122

Pasternak, Aleksandr

Leonidovich 30 (fn. 24), 162

Pasternak, Boris Leonidovich

(Borya) 2-3, 4, 11, 17-26, 28-34, 36-42, 161, 162, 164, 200, 217, 229, 230, 265, 266

"Aerial Ways" 20

"The Artist" 229

"The Beginning of the Novel about Patrick" ("Nachalo romana o Patrike") 20 (fn. 8)

"Behind them five blind checkpoints" ("Za nimi piat' slepykh zastav") 20

"Byt' znamenitym nekrasivo" 12 Correspondence of $\mathrm{P}$. and $\mathrm{O}$. M. Freidenberg (Perepiska; see also Freidenberg, O. M., Correspondence) 3 (fn. 4, 5), 4 ,
11-12, 17, 20, 27. 28, 29-30, $33,35,217$

Doctor Zhivago (also Boys and Girls, Mal'chiki i devochki) 20, 28-29, 30 (fn. 23), 31, 34, 35, 36 (Lara), 37, 38, 39-41, 217

"Holy Week" (Doctor Zhivago) 34

"Mad and greedy from insomnia"("Bezumnyi, zhadnyi ot bessonnits") 20 "The Mark of Apelles"("Apellesova cherta") 21

"Most likely, I am telling a fairy tale" ("Veroiatno, ia rasskazyvaiu skazku") 20

My Sister Life (Sestra moia zhizn) 17, 41

On Early Trains ( $\mathrm{Na}$ rannikh poezdakh) 28, 41

Safe Conduct (Okhrannaia gramota) 18, 19, 21, 29 (fn. 22), 30 (and fn. 23)

"Second Birth" 41

"Soul" 21

"The Station" ("Vokzal") 20

Twin in the Stormclouds

(Bliznets $v$ tuchakh) 20, 41

"Zhenia Liuvers's Childhood"

("Detstvo Liuvers") 22, 23-25, 30 (fn. 23)

Pasternak, Evgenii Borisovich

Boris Pasternak: Materialy dlia biografii 12 (fn. 20).

Pasternak, Leonid Osipovich (also "uncle Lenchik") 4, 17 (fn. 1), $18,27,115,155,162$

Memoirs 18 (and fn. 2), 30 (fn.

24), 52,53 (fn. 14)

Paul, Apostle (the Pauline teachings; see also Apocrypha) $41,47-50,52,53,55,58,60$

Pausanias 88 
Perchenok, Feliks

"Akademiia nauk na velikom perelome" 152 (fn. 2), 153 (fn. 5)

Perlina, Nina

"Ol'ga Freidenberg on Myth, Folklore, and Literature" 1 (fn. 1), 60 (fn. 31), 73 (fn. 7)

"From Historical Semantics to the Semantics of Cultural Forms" 11 (fn. 32), 250 (fn. 6)

"The Freidenberg-Bakhtin Correlation" 250 (fn. 6)

"Funny Things are Happening on the Way to the Bakhtin Forum" 81 (fn. 27), 249 (fn. 1)

"Primeval and Modern Mythologies..." 113 (fn. 35), 157 (fn. 12)

Perry, B. E.

"Chariton and his Romance from a Literary-Historical Point of View" 57 (fn. 24)

Petronius 64

Petrov, Dmitrii Konstantinovich 46 (fn. 1)

Petrovskii, Mikhail Aleksandrovich 136

Pigulevskaia, Nina Viktorovna 4 (fn. 6)

Pindar 6 (fn. 9), 9, 202-03, 204, 207, 220

"Olympia I" 220

Nemean 7,28 (fn. 19)

Pythia 207

Pierce, Charles 239

Piotrovskii Adrian Ivanovich 154, 237 (fn. 1)

Plato 38

The Politics 38, 234

"Seventh Letter" 222 (fn. 18), 234

Platonov, Sergei Fedorovich 152 (fn. 2)
Plautus

Bacchides 238

Pliukhanova, M. B.

"Veselovskii kak issledovatel' form istoricheskogo soznaniia" 63 (fn. 44)

Pokrovskii, Mikhail Mikhailovich 154

Poliakova, Sof'ia Viktorovna 197

Polivka, Jiř́i 60

Popkov, Petr Sergeevich 189

Potebnia, Aleksandr Afanasievich 59, 112, 178 (fn. 32)

Pravda 2, 215 (fn. 1)

Preobrazhenskaia, Sof'ia Petrovna 189 (fn. 12)

Propp, Vladimir Iakovlevich 3 , 60-62 (and F. on morphology and transformation of archaic genre structures -?-) , 105, 110 (fn. 29), 124, 139-43, 145, 258 (fn. 31)

Morphology of the Folktale (Morfologiia skazki) 61 (and fn. 35, 36), 105 (fn. 19), 139

"Oedipus in Light of Folklore" 140, 142 (fn. 30)

Problemy komizma i smekha 258 (fn. 31)

"Ritual Laughter in Folklore" 140, 142

Russkie agrarnye prazdniki 258 (fn. 31)

The Russian Folktale 143

"Spetsifika fol'klora" 143 (fn. 31,32 )

Theory and History of Folklore 258 (fn. 31)

"Transformations of the Wondertale" ("Transformatsii volshebnykh skazok") 61,62 (and fn. 35, 37, 40), 110 (fn. 29) 
Public Library (also Petrograd /Leningrad /St. Petersburg Public Library) 4 (fn. 6), 49, 53

Pushkin, Aleksandr Sergeevich "Autumn" 231

Rabelais, François 249

Reardon, Bryan P. 57, 58

The Form of Greek Romance 57(and fn. 25) ??

Reichardt, Konstantin

"Ernst Cassirer's Contribution to Literary Criticism" 179 (fn. 34)

Reinach, Salomon 258 (fn. 31)

Red Virgin Soil (Krasnaia nov) 159

Red Newspaper (Krasnaia gazeta) 156

Reitzenstein, Richard. 58

Robespierre, Maximilien 45

Rohde, Erwin 57

Rosler, Wolfgang

"Michail Bachtin und die

Karnevalskultur" 262 (fn. 36)

Rostovtsev, Mikhail Ivanovich 66, 78, 84 (fn. 37)

Ruiz-Montero, Consuelo

"The Structural Pattern of the

Ancient Greek Romance and.." 62 (fn. 38)

Sabashnikov, Mikhail Vasil'evich

Vospominaniia 66 (fn. 51)

Sacchetti, Franco 140

Saintyves, Pierre

Essais de folklore biblique 57 (fn. 24)

Salisbury, Harrison

900 Days 188

Sandys, John 6 (fn. 9)

Sappho 28, 31, 33, 198-200, 204, 205, 212, 213, 252
"Ornate-throned Immortal Aphrodite" 199

Saussure, Ferdinand de 78, 239

Schlipp, Paul Arthur 92 (fn. 57)

Schmidt, Karl

Reliquienkult im Altertum 49 (fn. 6)

Schneemelcher, Wilhelm 49 (fn. 6)

Serman, Il'ia Zakharovich

"G. A. Gukovskii..." 207 (fn.

25), 210 (fn. 35)

Shakespeare, William 107, 133, $140,141,217$

Shakhmatov, Aleksei

Aleksandrovich 46 (fn. 1)

Shishmarev, Vladimir Fedorovich 73 (fn. 7), 84

Shevoroshkin, Vitalii Viktorovich 72 (fn. 6)

Shklovskii, Viktor Borisovich 136 Shliapkin, Il'ia Aleksandrovich 46 (fn. 1)

Shmidt, Raisa Viktorovna 84, 112, 160,161

"Primeval Thinking in the Images of the Iliad"

("Pervobytnoe myshlenie v obrazakh Iliady") 112 (fn. 34)

Shneerson, Mariia Anatol'evna

"On chelovekom byl" 207 (fn. 25)

Shpitser, M. S.

"First Woman, Doctor of Literary Studies" ("Pervaia zhenshchina-doktor literaturovedeniia") 156 (and fn. 9)

Sikorski, Władysław 187

Smirnov, Aleksandr Aleksandrovich 121

Socrates 227 (fn. 30)

Sophocles 66

Sorokina, M. Iu. 
"Kratkoe opisanie materialov lichnogo arkhiva O. M. F." 2 (fn. 3), 3 (fn. 5), 32 (fn. 29)

Soviet Folklore (Sovetskii fol'klor)

128 (and fn. 23, 24)

Soviet Studies in Literature 1 (fn.

1), 101 (fn. 6)

Spengler, Oswald 115

Spender, Stephen

"Darkness and Light" 193

(epigr), 263 (epigr)

Spitzer, Leo 3, 184-85, 213

Classical and Christian Ideas of World Harmony 185 (fn. 5), 213, 214

"Geistesgeschichte vs. History of Ideas" 184, 185

State Editorial House (GIZ) 160 *

Stalin, Iosif Vissarionovich (and

Stalinism) 2, 6, 11, 75, 76 (fn.

13), 78, 79, 81, 83, 89, (fn. 50),

$126,128,160,183,185,187,196$,

215,216

"O nekotorykh voprosakh istorii

bol'shevizma" 83 (fn. 35)

Starostin, Sergei Anatolievich 73 (fn. 8)

Steiner, Peter 134, 136

Russian Formalism 133 (fn. 4), 136, 137 (fn. 17)

Struve, Vasilii Vasil'evich 84, 121

Sumarokov, Aleksandr Petrovich 208

Svitich, Vladimir 72 (fn. 6)

Tacitus 88

Tager, Elena Mikhailovna 4 (fn. 6)

Tarle, Evgenii Viktorovich 152

(fn. 2)

Tatum, James

The Darker Comedies, by

Plautus 238 (fn. 2)

Thomas, Lawrence L. 75, 80
The Linguistic Theories of N. Ja. Marr 75 (fn. 13)

Tikhaia-Tsereteli, M. G. 122

Times of Yore (Zhivaia starina)

128-29 (fn. 25)

Tischendorf (see Acta

apostolorum apocrypha)

Todd, William Mills

Fiction and Society in the Age

of Pushkin 206 (and fn. 24)

Tolstoi, Ivan Ivanovich 6 (fn. 9),

$59,125,154,266$

"The Language of the Folk Tale in Greek Literature" ("Iazyk skazki v grecheskoi

literature") 125 (and fn. 19), 195

Trauberg L. Z. 237 (fn. 1)

Tronskaia, Mariia Lazarevna 113

(fn. 37), 125 (fn. 20)

Tronskii (born Trotskii), Iosif

Matveevich 113, 114. 154, 156

(fn. 11)

"The Myth of Daphnis" 113, $114,195,267$

Trotskii, Lev Borisovich 45

Trubetskoi, Nikolai Sergeevich

"Les consonnes latérales" 80 (fn. 24)

Tsereteli, Grigorii Filimonovich 59

Tsyrlin, L. 92 (fn. 56), 156, 159, 160

Tukhachevskii, Mikhail

Nikolaevich 187

Turaev, Boris Aleksandrovich 46 (fn. 1)

Tylor, Edward 59

Primitive Culture and Anthropology 63

Tynianov, Iurii Nikolaevich 136 39 (and F. on literary development-?-) 
"On Literary Evolution" ("O

literaturnoi evoliutsii"), 13637 (fn. 12, 13, 16)

\section{University (also LGU and}

Department of Classical

Philology/Languages,

Literatures, and History) 2, 4, 5, $26,45,59,65-67,151,153,154-$ $55,156,159,160,161,195-98$, 201, 206, 215-17, 267, 268

Usener, Hermann 59, 60, 63, 105$06,112,258$ (fn. 31)

Die Sintfluthsagen 105 (fn. 20)

Uspenskii, Boris Andreevich 242, 245

"Tsar and Pretender" 242 (fn. 10)

Veselovskii, Aleksandr

Nikolaevich 54, 60, 63 (and fn. 44), 72-73, 112, 139, 171, 174, 178,196

Istoricheskaia poetika 54 (fn. 19)

Vico, Giambattista

Scienza nuova 82

Vishnevskii, Vsevolod Vital'evich 188

Voevodskaia, Mimi 186

Vostok - Zapad 70 (fn. 2), 71 (fn. 3)

Volin, Boris Mikhailovich 160, 161, 162

Voloshinov, Valentin Nikolaevich 91 (fn. 56), 249
Marxism and the Philosophy of

Language 81 (fn. 27)

Voprosy literatury 32 (fn. 27)

Vulikh, Natal'ia Vasil'evna 196

Vvedenskii, Aleksandr Ivanovich 46

Wellek, René 184

Wright, William 49 (fn. 6), 53 (fn.

16)

Apocryphal Acts of the Apostles 49 (and fn. 6)

Xenophon Ephebius (and apocrypha) 56

Zaitsev, Aleksandr Iosifovich 197

Zelenin, Dmitrii Konstantinovich 54 (fn. 19), 124, 125

Zelinskii, Faddei Frantsievich

(Tadeusz Zielinski) 46 (fn. 1), 65, 66

Zhebelev, Sergei Aleksandrovich $46,47,48,49,50,52,55,59,60$, $63,65,67,69,134,151,152,154$, $156,159,266,267$

"Iakov Ivanovich Smirnov" 46 (fn. 2)

Apostle Paul and His Epistles (Apostol Pavel i ego poslaniia. Obshchii ocherk) 48-49 (and fn. $5,6,7$ ), 50 (and fn. 8, 9), 59 (fn. 28)

Zhirmunskii, Viktor Maksimovich 6 (fn. 9), 124, 125, 126-27, 186 Zinov'ev, Grigorii Evseevich 45 Zoshchenko, Mikhail Mikhailovich 196 